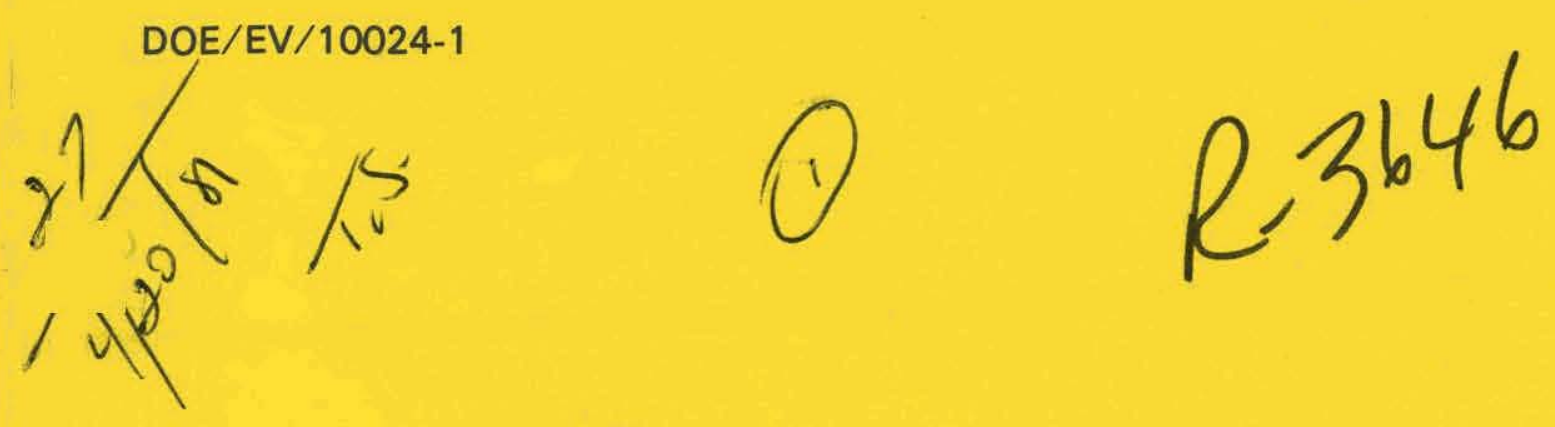

\title{
Recommended Research on LNG Safety
}

March 1981

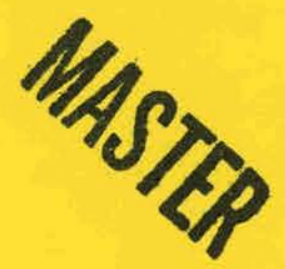

Prepared for:

U.S. Department of Energy

Assistant Secretary for Environment

Environmental and Safety Engineering Division

Under Contract No. DE-ACO3-79EV10024 


\section{DISCLAIMER}

This report was prepared as an account of work sponsored by an agency of the United States Government. Neither the United States Government nor any agency Thereof, nor any of their employees, makes any warranty, express or implied, or assumes any legal liability or responsibility for the accuracy, completeness, or usefulness of any information, apparatus, product, or process disclosed, or represents that its use would not infringe privately owned rights. Reference herein to any specific commercial product, process, or service by trade name, trademark, manufacturer, or otherwise does not necessarily constitute or imply its endorsement, recommendation, or favoring by the United States Government or any agency thereof. The views and opinions of authors expressed herein do not necessarily state or reflect those of the United States Government or any agency thereof. 


\section{DISCLAIMER}

Portions of this document may be illegible in electronic image products. Images are produced from the best available original document. 


\section{Notice}

This report was prepared as an account of work sponsored by the United States Government. Neither the United States nor the United States Department of Energy, nor any of their employees, makes any warranty, express or implied, or assumes any legal liability or responsibility for the accuracy, cumpletencss, or usefulness of any information, apparatus, product, or process disclosed, or represents that its use would rut infringe privately owned rights. Reference herein to any specific commercial product, process, or service by trade name, mark, manufacturer, or otherwise, does not necessarily constitute or imply its endorsement, recommendation, or favoring by the United States Government or any agency thereof. The views and opinions of authors expressed herein do not necessarily state or reflect those of the United States Government or any agency thereof.

Printed in the United States of America

$$
\text { Available from }
$$

National Technical Information Service

U.S. Department of Commerce.

5285 Port Royal Road

Springfield, VA 22161

NTIS price codes

Printed Copy: $\quad \$ 18.00$

Microfiche Copy: $\$ 3.50$ 


\section{Recommended/Research on LNG Safety}

March 1981

Prepared by:

R\&D Associates

P.O. Box 9695

Marina del Rey, California 90291

Prepared for:

U.S. Department of Energy

Assistant Secretary for Environment

Environmental and Safety Engineering Division

Washington, D.C. 20585

Under Contract No. DE-AC03-79EV10024

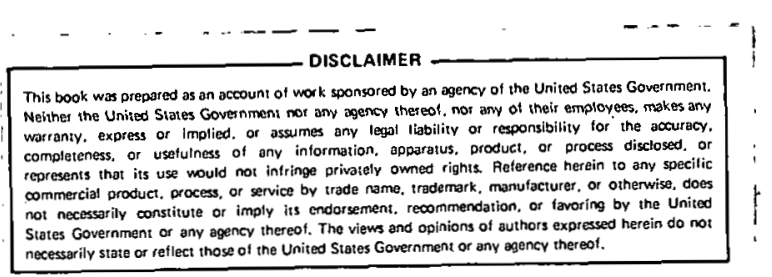


TABLE OF CONTENTS

Section

Page

LIST OF FIGURES

vii

LIST OF TABLES

$\mathbf{x}$

EXECUTIVE SUMMARY

xiii

I

INTRODUCTION

$1-1$

1. Background

1-1

2. Objectives

$1-2$

3. Scope

1-3

II

CURRENT PROCEDURES FOR OBTAINING

ING PERMIT APPROVAL

2-1

1. Introduction

2-1

2. ING Regulation in General

$2-4$

3. Case Histories

$2-24$

REFERENCES FOR SECTION II

$2-61$

III

LNG SAFETY INFORMATION FOR

REGULATORY PURPOSES

$3-1$

1. Introduction

$3-1$

2. Federal and state Regulations

3-1

3. Perceived Key Research Needs

3-12

REFERENCES FOR : SECTION III

$3-17$ 
TABLE OF CONTENTS (CONTINUED)

Section

Page

IV

GENERAL FEATURES OF THE RECOMMENDED

LNG SAFETY RESEARCH PROGRAM

$4-1$

1. Introduction

$4-1$

2. "Rapid" versus "Gradual" Research Approach

$4-2$

3. High Priority LNG Spill Situations

$4-4$

4. Mitigation Research

$4-6$

REFERENCES FOR SECTION IV

$4-8$

$\mathrm{V}$

RECOMMENDED RESEARCH ON LNG

SPREADING AND BOILOFF.

$5-1$

1. Introduction

$5-1$

2. Experiments

$5-10$

3. Mathematical Modeling

$5-31$

REFERENCES FOR SECTION V

$5-33$

VI

RECOMMENDED RESEARCH ON ING VAPOR CLOUD DISPERSION

$$
6-1
$$

1. Introduction

$6-1$

2. General Features of LNG Vapor Dispersion

$6-6$

3. Technical Approach

$6-13$

4. Experimental Program

$6-15$

5. Mathematical Modeling Program

$6-49$

REFERENCES FOR SECTION VI

$6-70$ 
TABLE OF CONTENTS (CONTINUED)

Section

Page

VII RECOMMENDED RESEARCH ON LNG

POOL FIRES

$7-1$

1. Introduction

$7-1$

2. Research Goals and Technical Approach

$7-7$

3. Experimental Program

7.-9

4. Mathematical Modeling

$7-20$

REFERENCES FOR SECTION VII

$7-23$

VIII

RECOMMENDED RESEARCH ON

VAPOR-CLOUD FIRES

$8-1$

1. Introduction

$8-1$

2. Experimental Program

$8-3$

3. Mathematical Modeling

$8-8$

REFERENCES FOR SECTION VIII

$8-10$

IX

RECOMMENDED RESEARCH ON THE

POTENTIAL OF LNG VAPOR EXPLOSIONS

$9-1$

1. Introduction

$9-1$

2. Recommended Research on Detonation

$9-10$

3. Recommended Research on Rapid Deflagration

$9-16$

4. Extended Program

$9-20$

REFERENCES FOR SECTION IX

$9-21$ 
TABLE OF CONTENTS (CONCLUDED)

Section

Page

$\mathrm{X}$

PRELIMINARY COST ESTIMATE

AND TIME SCHEDULE

$10-1$

1. Summary of Costs

10-1

2. Individual cost Estimates

$10-1$

3. Time Schedule

$10-7$

$X I$

TECHNICAL REVIEWERS' COMMENTS

$11-1$

AND OUR RESPONSE

11-1

1. Introduction

11-2

2. Comments on the Summary

11-2

3. Comments on the Introduction

$11-2$

4. Comments on section II (Permit Procedures)

5. Comments on section III (Information for Regulatory Purposes)

$11-2$

6. Comments on Section IV (General

Features of the Recommended Program) 11-3

7. Comments on section V (LNG Spreading and Boiloff)

8. Comments on Section VI (Vapor Dispersion)

9. Comments on Section VII (Pool Fires) 11-9

10. Comments on Section VIII (Vapor Cloud Fires) $11-10$

11. Comments on Section IX (Explosions) 11-11

12. Comments on section $X$ (Cost and Estimates)

$11-12$

REFERENCES FOR SECTION XI

$11-14$

APPENDIX

$A-1$ 
LIST OF FIGURES

Figure

Page

2-1 Flow chart: LNG licensing/

permitting sequence

$2-16$

2-2 Corporate arrangements for

Algeria II project

$2-26$

5-1 Measured boiloff rates of LNG

on soil and insulating concrete 5-3

5-2 Experimental and theoretical

diameter vs time for an instan-

taneous LNG spill on water

$5-5$

5-3 Comparison of measured and

theoretical LNG pool diameters

for two constant-rate spills

on water

$5-8$

5-4 Sketch of swimming pool installa-

tion (side view) and ship model

5-17

5-5 Maximum LNG pool radius and duration for an instantaneous spill on water, according to the theory of Raj and Kalelkar (Ref. 5-6), assuming a constant boiloff rate of $0.042 \mathrm{~cm} / \mathrm{s}$

Instrumentation arrangement for the swimming pool tests (top view)

$5-25$

Maximum distance to the LFI (5 percent mean vapor concentration) predicted by two analytical models and by scaling wind tunnel results, for instantaneous spills of LNG on water in a $2.2 \mathrm{~m} / \mathrm{s}$ wind

6-2 Visualization of the plume from the low dike model in a wind tunnel simulation test (Refs. 6-3,6-4)

wind tunnel contours of 5 percent helium-nitrogen (corresponding to 5 percent methane) at the ground level. for a low dike at 45-degree orientation (included on the left of the figure) in a neutral atmosphere (Ref. 6-4). The coordinates and curves are labeled with the full-scale distances, vapor release rates, and wind speeds 


\section{LIST OF FIGURES (CONTINUED)}

Figure

Page

6-4 A comparison between entrainment velocities produced by a stirring grid, across density interfaces formed with - temperature differences and 0 salinity differences (Ref. 6-14)

6-5 Examplcs of turbulent mixing just downstream of a gravity driven cloud (Ref. 6-15)

6-6 Layout of the test section for LNG vapor dispersion measurements in the future NASA-Ames $37-\mathrm{m}$ wind tunnel

6-7 Reduced concentration data from wind tunnel tests of steady and transient vapor releases from low-dike models using $\mathrm{CO}_{2}$ as a simulation gas (Ref, 6-3)

Reduced concentration data from wind tunnel tests of steady and transient vapor resleases from high-dike models using $\mathrm{CO}_{2}$ as a simulation gas (Ref. 6-3)

6-9 A Lagrangian Raleigh-Taylor calculation. The heavier upper. layer collapses generating vortices at $t=0.119 \mathrm{~s}$. At $t=$ $0.140 \mathrm{~s}$ the upper fluid has almost reached the bottom of the container and the vortices begin to $\mathrm{mix}$ the fluid layers. The vortices continue to roll-up at $t=0.152$ as the heavier fluid breaks over a bubble of lighter fluid. The lighter fluid is now multiplyconnected since the heavier fluid has touched the bottom. The interface has been manually darkened for contrast (Ref, 6-30) 
Figure

Page

6-10 Examples of numerical diffusion errors for several Eulerian integration schemes for the advection of a peaked wave (Ref. 6-31)

$7-1$

Experimental data and semiempirical fits to the surface-radiant fluxes of LNG pool fires

$7-2$

Sketch of the expected flame geometry for LNG pool fires on water, based on the Raj-Kalelkar pool spread model (with a boiloff rate of $0.065 \mathrm{~cm} / \mathrm{s}$ ) and the Thomas flame-height correlation

Compact mass of high explosive required to initiate detonation in a stoichiometric mixture of air and methane with a varying fraction of ethane or propane

9-2 Turbulent burning velocity (with respect to the unburned gas) observed on LNG test spills when the vapor cloud was ignited near the downwind end (Ref. 9-12)

10-1 Test site for large LNG field tests 
Table

Page

$2-1$

Persons contacted concerning

LNG permit procedures

2-2

Summary: of responsibilities of federal agencies, LNG facilities and operations

Major regulatory responsi- :. bilibies for LNG facilities

summary of federal requirements for permits for LNG facilities and operations

Characteristics of E1 Paso Company's Algeria II project

Chronology of events-Algeria II project application for Lasalle terminal

Organizational structure of the Western LNG project

Chronology of events--the Western ING project

LNG peakshaving plant facilities-U.S. and Canada

LNG satellite facilities small capacity--field constructed)

2-12 Chronology of events--Northwest. Pipeline LNG II

Currently perceived safety parameter uncertainties and research goals

"Swimming pool" test program 
6-2 Recommended tests in a mediumsize wind tunnel ( $4 \mathrm{~m}$ widé) for modeling the vapor dispersion from large and small LNG spills on water (linear scale factor 1/1000)

Recommended tests in a mediumsize wind tunnel- ( $\sim 4$ m wide) for modeling the vapor dispersion from ING spills in low and high dikes (linear scale factor 1/125)

6-4 Recommended tests in a large. wind tunnel ( $40 \mathrm{~m}$ wide) for modeling the vapor dispersion from LNG spills (linear scale factor $1 / 150$ for spills on water, tests $1-20$, and $1 / 20$. for spil1s on land, tests 21-38)

Recommended field tests for modeling the vapor dispersion from LNG spills (linear scale factor $1 / 4.1$ for spil1s on water, tests $1-9$, and $1 / 3.2$ for spills on land; tests 10-21)

Recommended instrumentation for the field tests of ING vapor dispersion

Mathematical modeling task 1-preliminary code evaluation and improvement

6-8 Mathematical modeling task 2-preliminary sensitivity analysis . . . 6-57

6-9 Recommended preliminary water spill calculations $\left(25,000 \mathrm{~m}^{3}\right.$. spill, no ships) spill calculations $\left(28,000 \mathrm{~m}^{3}\right.$ spill, no dike walls or tank structure) 
LIST OF TABLES (CONCLUDED)

Table

$\underline{\text { Page }}$

6-11 Mathematical modeling task 3-numerical diffusion suppression (if required)

$6-61$

6-12 Dispersion modeling task 4--

turbulent mixing tests

$6-62$

6-13 Mathematical modeling task 5-turbulent-mixing model improvements

$6-63$

6-14 Mathematical modeling task 6-numerical simulation of smallscale wind tunnel tests

$6-64$

6-15 Mathematical modeling task 7-numerical simulation of field tests

$6-65$

6-16 Mathematical modeling task 8-numerical simulation of largescale wind tunnel tests

$6-66$

6-17 Mathematical modeling task 9-final numerical predictions of LNG vapor-cloud dispersion

$6-67$

$6-18$

Mathematical modeling task 10-code development for modeling coherent vorticity

$6-68$

$7-14$

7-1

Recommended LNG pool fire tests

$7-17$

fire tests

$8-1$

$9-1$

Recommended LNG vapor cloud fire tests

$$
8-5
$$

Recommended explosion tests on LNG vapor clouds from large test spills

$9-19$

$10-1$

Summary of estimated costs

10-1 


\section{EXECUT IVE SUMMARY}

\section{MAJOR FINDINGS}

LNG Permit Procedures

- The LNG regulatory process imposed by federal, state and sometimes local agencies is complex and continually changing.

Safety Information for Regulatory Purposes

- Individuals in governmental and industrial organizations concerned with. ING safety have a wide range of opinions on the current uncertainties in predictions of LNG spill phenomena relevant to safety regulations, and on the research needed to improve these prodictions. For example, opinions concerning the uncertainty in the maximum flammable range from a large LNG spill vary from a factor of 1.2 to a factor of 10 . On the question of further research, some believe that none is needed, while others favor extensive research involving large tests, and many hold intermediate positions.

General Features of the Recommended Research Program

- Current understanding of the spreading and boiloff of spilled LNG, dispersion of the vapor, and its possible combustion or explosion is not sufficient for making safety predictions with the confidence and accuracy needed to satisfy some regulatory agencies, operating companies, and public representatives.

- The situations of greatest uncertainty, and of greatest public concern, involve very large spills, such as could conceivably occur due to massive rupture of a large LNG tark by a ship collision, earthquake, or 
other catastrophe. Although much less probable than small accidental spills, such large accidents cannot be ruled out and deserve high priority in a future research program.

- By a coordinated combination of wind tunnel tests, field tests (including a number of large test spills) and mathematical modeling, the high-priority ING safety questions can be answered with good confidence and accuracy in about three years and at a cost of about $\$ 21$ million (in 1979 dollars).

MAJOR RECOMMENDATIONS

Spreading and Boiloff

- It is recommended that the current significant uncertainties in LNG spreading and boiloff be reduced by performing about 30 test spills of $0.5 \mathrm{~m}^{3}$ of LNG on water, with simulated ship geometries and extensive instrumentation, supplemented by relatively simple mathematical modeling.

Vapor Dispersion

- It is recommended that a number of vapor dispersion tests be carried out in wind tunnels, employing scaleddown models of the large land and water spills of interest (including associated tanks, dikes, ships, etc.) with the wind speeds reduced to duplicate the full-scale Froude numbers. Preferably, actual LNG should be spilled or LNG vapor released in these tests; this procedure is believed to be safe in nonrecirculating wind tunnels although, if not permitted, nonflammable simulants can be used with some loss in accuracy. About 100 tests should be conducted in a medium-size wind tunnel (such as the Environmental 
Wind Tunnel at Colorado State University), and about 40 tests in a large wind tunnel (such as the $37-\mathrm{m}$ wind tunnel at NAṢA Ames). In this way, many combinations of spill size and configuration, wind speed, atmospheric stability, and humidity can be investigated at reasonable cost.

- About 25 relatively large field tests on land and water, Froude-scaled like the wind tunnel tests, are also recommended. These tests are needed to verify, by comparison with the equivalent wind tunnel tests, that Froude scaling is indeed valid and that the practical inability to duplicate the Reynolds number and the dimensionless heat-transfer has either a negligible effect or an effect small enough to be safely extrapolated to full-scale spills. By choosing the largest test spills to be about $350 \mathrm{~m}^{3}$, the Reynolds number variation between wind tunnel and field test is a factor of 4000, while that between the field test and an actual complete tank rupture is only a factor of 1.7 . Going to a larger test spill would improve the simulation only slightly while increasing the cost greatly.

- A large number of vapor concentration sensors with good time resolution should be employed on each wind tunnel and field test to provide an accurate map of the concentration field. Tests in the large wind tunnel and in the field should also include a few sensors that distinguish between the components of LNG (methane, ethane and propane) because of their different sensitivity to detonation initiation. 
- Several mathematical modeling tasks are recommended to develop computational tools which can be used (after verification or calibration by comparison with experiment) to investigate the sensitivity of vapor diffusion to parameters that are difficult to scale or control experimentally. These tools would be three-dimensional numerical hydrodynamic codes incorporating appropriate models of turbulent flow and mixing.

Pool Fires

- It is recommended that 14 ignited spill tests be performed, about half of them as large as the largest vapor dispersion spills, with the remainder somewhat smaller. Since the basic properties of large pool fires are expected to vary only slowly with size, extrapolation of the results from these tests to larger accidental fires should be reasonably accurate.

- The instrumentation for these fire tests should include not only the usual radiometers and movie cameras, but also an airborne camera overhead, a fast infrared spectrometer, and an infrared camera to give a complete record of the spatial variation of the flame radiation.

- The mathematical analysis recommended for pool flames involves developing a simple semiempirical flame model, adjusted to fit the experimental results, and a somewhat more basic model, which treats the fluid flow and radiation on a global basis (without the detail of a numerical finite-difference calculation).

Vapor-Cloud Fires

About 15 field experiments involving large test spills with later ignition of the vapor cloud are recommended. 
The ignition time and position should be chosen to maximize the size or the downwind extent of the flammable region, as determined from the earlier vapor dispersion tests.

- Instrumentation for these tests should be similar to that described for the pool fire tests, with the addition of some vapor concentration sensors, anemometers, and flame-front detectors. .

- Two types of mathematical models for vapor-cloud fires should be developed: a simple semiempirical model and an axially symmetric finite-difference model for centrally ignited clouds, incorporating an empirical burning velocity that could vary with position and time if experiments so indicate.

\section{Explosions}

- A survey should be made of the potential detonationinitiation sources that might be found within the vapor dispersion range of LNG facilities and carrier berths. Those potential sources that could not be eliminated by simple analysis should be tested to determine whether they could initiate detonation, first in large bags of LNG vapor and air, and finally in the vapor clouds from open test spills.

- For the latter experiments, five large test spills are recommended, each having about 25 initiators spaced over the predicted flammable region and set off simultaneously. Pressure gages and airborne cameras would determine which, if any, of these actually started detonations. 
- Calculations using one-dimensional and two-dimensional hydrocodes that include combustion kinetics are also recommended to help in predicting the effectiveness of initiators and the influence of vapor cloud inhomogeneities.

- Tests of the possibility of initiating detonation in an aerosol of LNG droplets should be carried out, first in large bags and then in unconfined clouds produced by the explosive dispersal of a fraction of a cubic meter of LNG.

- Several types of tests are needed to determine whether partial confinement, obstacles, or high turbulence levels in LNG vapor-air mixtures can increase the burning velocity sufficiently to produce damaging overpressures, even if they fall short of those from a true detonation. The first tests should be performed in large containers or bags with obstacles and/or fans inside.

- The largest flame-acceleration tests should involve six or eight LNG test spills of maximum size, with ignition of the resulting vapor cloud after it drifts into a large array of obstacles, such as simulated cars in a parking structure.

- Instrumentation for the flame-acceleration tests should include all of the instruments recommended for vapor-cloud fires, plus pressure sensors throughout the test region.

- Two-dimensional hydrocode calculations are recommended to predict the effects of flame acceleration and buoyancy on fires larger than can feasibly be tested. The code employed should include an 
adequate turbulence model and a flame model based on an empirical relation between burning velocity and turbulence derived from separate experiments with fans in a large container.

COST ESTIMATE AND TIME SCHEDULE

- Based on a fairly detailed analysis of the individual tasks recommended above, it is estimated that the. entire research program can be carried out in about three years for $\$ 21$ million (in 1979 doliars), provided that personnel with the appropriate experience and motivation are employed. 


\section{INTRODUCTION}

\section{BACKGROUND}

The U.S. Department of Energy (DOE) Division of Environmental control Technology is currently conducting research on the safety and other environmental aspects of liquefied energy gases including liquefied natural gas (LNG). The effort reported here was conducted as part of the planning for further research into the safety aspects of transporting and storing LNG, with primary emphasis on public safety. Although the modern LNG industry has enjoyed excellent success in providing for safe operations, significant questions remain on the part of many, the expressions of which were intensified with the addition of marine-based ING import terminals. Public safety with regard to large-scale importation of this fuel has received widespread attention in the U.S Congress, state legislatures, county and city governments, and from various individuals and public groups, with coverage in all the news media, including books published on the subject. The safety concerns have centered around the consequences to the public of a large spill of the cryogenic liquid from an ocean tanker or a large storage tank, either of which might hold as much as $125,000 \mathrm{~m}^{3}$ of LNG.

The perceived extent of fire and explosion effects from such spills has given rise to most of the public controversy. Such concerns have led to the passage of at least one state law requiring remote siting of ING terminals. Safety standards have been prepared by federal agencies, primarily the Department of Transportation (DOT), and the public utility agencies of a number of states to assure the safe design and operation of ING facilities and carriers. In the passage of safety-related laws, preparation of safety standards, selection of LNG facility sites, design and operation of facilities 
and carriers, and maintenance of safe zones, reliable information is needed on the technology required to prevent accidental spills, to predict the potential hazardous effects should prevention fail, and to mitigate such effects to the extent required for safety.

The considerable research conducted already by government and industry has provided information for the successful design of liquefaction, storage, and regasification facilities, highway tankers and ocean carriers, as illustrated in the united states by over sixty operating peakshaving facilities, three operating import terminals with their serving carriers and one export terminal. Since no major spills have occurred in the modern LNG industry, the spill-preventive aspects of the design, construction and operating methods seem to be well founded. While further advances will probably be made in this area, the larger uncertainties appear to lie in the prediction of the extent of potential fire effects and whether a significant explosion could occur should the unanticipated large accidental spill occur from a storage tank onto land or water, and in determining the best ways to minimize the consequences of these effects.

\section{OBJECTIVES}

The primary objectives of this work were to state the perceived needs for reducing the uncertainties associated with the current capability for predicting quantitatively the extent of fire and explosion effects for full-scale spills, and to recommend the elements of a research program for reducing these uncertainties to desired values. The aim was to structure the program so as to develop the tools needed for obtaining reliable descriptions of the major technical phenomena and to exercise those tools to answer key safety questions at a minimum cost and time. Secondary objectives were to identify additional research elements to provide more precise and 
scientifically complete answers over a somewhat longer time period. A task was also included to prepare a description of the typical steps that applicants for LNG facility construction and operating licenses are required to follow.

\section{SCOPE}

This work addresses the LNG spill consequences, with consideration given to liquefied petroleum gas (LPG) only insofar as the research requirements for that fuel are common with those for LNG. It concentrates on the mathematical modeling, laboratory research and field experiments required for describing the liquid spreading and vaporization, vapor dispersion, and vapor combustion of spills from tankers onto water and from land-based storage tanks into dike-impounded areas. Spill prevention is not addressed; however, provisions are included for determining the performance of certain passive mitigation techniques for land spills, such as the thermal insulation of impounding surfaces and the use of high dikes. The methodology and test capabilities developed would be directly useful for evaluating a wide variety of mitigation measures, both active and passive. Most of it would also apply to analytical and experimental efforts for defining similar safety information for LPG. Cost and schedule estimates were developed for the research recommended.

Section II presents the responsibilities of various regulatory agencies and the major steps required for an applicant to obtain approval to construct and operate LNG facilities; the reader primarily interested in the technical content may wish to skip that section. 


\section{CURRENT PROCEDURES FOR OBTAINING \\ LNG PERMIT APRROVAL}

\section{INTRODUCTION}

This section was prepared as a part of Task 1 of the work statement. It responds specifically to the following:

Prepare typical flow diagrams of the steps applicants for a construction or operating license must go through, indicating the likely timing and sequence of events.

While the bulk of the contract effort focuses specifically on safety research, the scope of the investigation was broadened to cover all categories of licenses and permits because:

- Safety issues are often imbedded in other issues, such as siting and economics.

- Safety issues can and should be addressed in parallel with other issues. It is important to understand overall sequence and timing.

The material contained in this section is applicable to two generic types of LNG facilities-marine terminals and peakshaving facilities. Marine terminals comprise largecapacity tanks for storing LNG brought to the contiguous United states from overseas, and vaporization facilities for sendout to major pipelines. Peakshaving facilities are smaller in scale and typically include liquefaction facilities. Smaller peakshaving facilities which store LNG brought by truck, and therefore have no liquefaction capabilities, are called satellite facilities.

The information contained herein came from a variety of sources, including prior reports on LNG by the U.S. General Accounting office, the Congressional office of Technology 
Assessment, the state of Washington, and Battelle Memorial Institute (Refs, 2-1 to 2-4), as well as direct discussions with staff personnel within the five governmental agencies and three private companies involved in LNG distribution. A list of persons contacted is contained in Table 2-1.

The reader is cautioned that a generalized flow diagram of the permitting process for LNG facilities could not provide a true and complete representation of what actually happens for several reasons:

- Differences in scope can cause projects to fall under different jurisdictions having different requirements for approval.

- The Department of Energy (DOE) has not yet estab- . lished an overall policy for licensing of LNG facilities and is handing applications case-bycase in the interim.

- The Materials Transportation Board (MTB) of the Department of Transportation (DOT) is in the process of revising its regulations for safety of LNG facilities.

- There is considerable variation among states in the scope and intensity of their laws relating to LNG facilities.

Despite these limitations, the permitting sequence is described in general terms in subsection 2 of this section, and case histories are presented in subsection 3. The latter illustrate the point that generalizations could be misleading. A cursory examination of the histories of other applications for LNG facilities (including those withdrawn or denied, such as the predecessors to the current western LNG Terminal project, the Staten Island Project, or the Tenneco Raccoon Island 
TABLE 2-1. PERSONS CONTACTED CONCERNING 1. LNG PERMIT PROCEDURES

DOE

Mr. Robert Arvedlund

Ms. Lynne Church

Mr. Finn Nielsen

Mr. Henry Santiago

Dr. Leonard Topper

DOT

Dr. Alan Schneider

Mr. Cesar Deleon

Corps of Engineers

Mr. Curt is Clark

Office of Technology Assessment

Mr. Peter A. Johnson

California Public Utilities Commission

Mr. Lionel Wilson

El Paso LNG Company

Mr. Luino Dell'Osso, Jr.

Western LNG Terminal Associates

Ms. Jerri Garcia

Northwest Pipeline Company

Mr. Robert Guterry

Mr. Art Sutton 
Project) leads one to conclude that each project actually has a unique history. The generalized proces's described in this report represents the ideal, not the reality, of LNG permitting.

2. LNG REGULATION IN GENERAL

a. Organizational responsibilities--The responsibilities for safety and environmental aspects of LNG projects are divided among various federal, state, and local ágencies along a number of different lines. Moreover, parts of these responsibilities are sometimes imbedded within other broader ones. To understand this division requires examination of the purviews of these agencies in relation to the entire permitting process for LNG projects.

The lines of division include (1) function, such as siting regulation, permitting, or enforcement; (2) jurisdiction, such as international, interstate, or intrastate; (3) system component, such as vessel, terminal, or pipeline; and (4) topography, such as waterway, waterfront, or wetland.

Along functional lines, safety regulations for all LNG facilities are promulgated by the MTB and the U.S. Coast Guard (USCG) of the DOT (Ref. 2-5). Compliance with those regulations is enforced by the MTB and the USCG. The coast Guard's responsibility applies only to shoreline terminals and extends from the start of U.S. waters to the storage tanks at such terminals, and includes security and fire protection for the facilities (Ref. 2-6). This responsibility nominally terminates at the entry to the storage system, and there the MTB's begins. The exact interface is facilityspecific, as agreed between the USCG and the MTB. The USCG's responsibility for fire control and plant security extends beyond this interface, to include the storage system to the point of gas sendout for consumption. 
Evaluations of LNG facilities along economic lines are the responsibility of the DOE's Economic Regulatory Administration (ERA), and those pertaining to design and construction are performed by the DOE's Federal Energy Regulatory Commission (FERC) (Ref. 2-7) and the U.S. Army Corps of Engineers (COE) (Refs. 2-8, 2-9). Along jurisdictional lines, the ERA is responsible for approval of international projects, the FERC for interstate projects, and state agencies for intrastate activities. Along component lines, the coast Guard is responsible"for vessels and equipment for transferring LNG to storage, while the MTB is responsible for storage and distribution equipment. Along topographic lines, the $\mathrm{COE}$ is responsible for construction over water or wetlands, and the Department of Interior is responsible for construction on public lands.

Complications result from the fact that these lines change from time to time as a consequence of organizational changes within the government or the passage of new legislation. The formation of the DOE in 1977, for example, resulted in the transfer of responsibility for administering the Natural Gas Act from the Federal Power Commission (FPC) to two units of the DOE: the FERC and the ERA. The discussion which follows describes the organization for administering LNG projects as it existed in mid-1979.

Table 2-2 summarizes the responsibilities of the federal agencies that participate in the approval process. Among them, five agencies within three departments hold the keys to new projects involving ocean transport of LNG to domestic terminals. These are the ERA and the FERC within the DOE; the U.S. ArmY COE; and the MTB and the USCG within the DOT. For projects involving interstate overland transport of LNG, the coast Guard is not involved. For intrastate projects, the MTB authorizes state governments to administer regulatory 

TABLE 2-2. SUMMARY OF RESPONSIBILITIES OF FEDERAL
AGENCIES, LNG FACILITIES AND OPERATIONS

\begin{tabular}{|c|c|c|c|}
\hline Organization & Document at ion & Responsibility & Authority \\
\hline $\begin{array}{l}\text { Department of Energy - } \\
\text { Economic Regulatory } \\
\text { Administration (ERA) }\end{array}$ & Order for Import/Export & $\begin{array}{l}18 \text { CFR 153: Regulate } \\
\text { the importation of } \\
\text { natural gas; coordinate } \\
\text { with Department of State } \\
\text { on national security } \\
\text { implications. }\end{array}$ & $\begin{array}{l}\text { PL } 75-688 \\
\text { Natural Gas } \\
\text { Act of } 1938 \text {, } \\
\text { Section } 3 \\
15 \text { U.S.C. } \\
\text { \$171a et seq. } \\
(1970)\end{array}$ \\
\hline $\begin{array}{l}\text { Department of Energy - } \\
\text { Federal Energy } \\
\text { Regulatory } \\
\text { Commission (FERC) }\end{array}$ & $\begin{array}{l}\text { Certificate of Public } \\
\text { Convenience \& Necessity } \\
\text { Environmental Impact } \\
\text { Statement (EIS) } \\
\text { prepared by FERC }\end{array}$ & $\begin{array}{l}18 \text { CFR 3, 156: Regulate } \\
\text { construction and operation } \\
\text { of LNG facilities. Coor- } \\
\text { dinate with other federal } \\
\text { agencies. Assure compli- } \\
\text { ance with state and local } \\
\text { requirements. }\end{array}$ & $\begin{array}{l}\text { PL } 75-688 \\
\text { Natural Gas } \\
\text { Act of } 1938 \text {, } \\
\text { Sect ions } 4 \\
\text { through } 7\end{array}$ \\
\hline $\begin{array}{l}\text { Department of } \\
\text { Defense - Corps. } \\
\text { of Engineers } \\
\text { (COE) }\end{array}$ & Construction permit & $\begin{array}{l}33 \text { CFR 209, 120: Consult } \\
\text { NOAA, EPA, USFWS; } \\
\text { review economic and } \\
\text { environmental impacts, } \\
\text { state and local wishes } \\
\text { and "overall public } \\
\text { interest" }\end{array}$ & $\begin{array}{l}\text { PL } 92-500 \\
\text { Rivers and } \\
\text { Harbors Act } \\
\text { of } 1899 . \\
33 \text { U.S.C. } \$ 401 \\
\text { Coastal Zone } \\
\text { Management } \\
\text { Act of } 1972 \\
16 \text { U.S.C. } \\
\text { et seq. }\end{array}$ \\
\hline
\end{tabular}


TABLE 2-2. CONTINUED

\begin{tabular}{|c|c|c|c|}
\hline Organization & Document ation & Responsibility & Authority \\
\hline $\begin{array}{l}\text { Department of } \\
\text { Transportation, } \\
\text { Material Transporta- } \\
\text { tion Bureau (MTB), } \\
\text { Office of Pipeline } \\
\text { Safety Regulation (OPSR) }\end{array}$ & $\begin{array}{l}\text { Regulations: } \\
\text { - NFPA 59A } \\
\text { - 42FR20776 (proposed) } \\
\text { - } 44 F R 8142 \text { (proposed) } \\
\text { - MOU MTB/CG } \\
\text { - Cert if ication by } \\
\text { state that CFRs are } \\
\text { followed as minimum }\end{array}$ & $\begin{array}{l}49 \text { CFR 171-179, } 192 \\
192.12,193 \text { (proposed): } \\
\text { Regulate LNG facilities } \\
\text { to guard against risk of } \\
\text { fire, radiant heat, explo- } \\
\text { sion or asphyxiation from } \\
\text { leaks or spills } \\
\text { Enforce rules }\end{array}$ & $\begin{array}{l}\text { Natural Gas } \\
\text { Pipeline Safety } \\
\text { Act of 1968 } \\
\text { (PL 90-481) } \\
49 \text { U.S.C. } \\
1671 \text { et seq. } \\
\text { (1970) }\end{array}$ \\
\hline $\begin{array}{l}\text { Department of } \\
\text { Transportat ion - } \\
\text { U.S. Coast Guard } \\
\text { (USCG) }\end{array}$ & $\begin{array}{l}\text { Letters of compliance } \\
\text { (for ships) } \\
\text { Permits for pipeline } \\
\text { crossings of navigable } \\
\text { waters }\end{array}$ & $\begin{array}{l}46 \text { CFR } 30-40,147,151, \\
152,154 . \\
33 \text { CFR } 6,66,115,124, \\
125: \\
\text { Inspect vessels during } \\
\text { construction or upon entry } \\
\text { to U.S. waters } \\
\text { Inspect waterfront } \\
\text { facilities } \\
\text { Restrict and regul ate } \\
\text { vessel movement } \\
\text { Hazard containment, pre- } \\
\text { vention, control (except that } \\
\text { fire control after sendout } \\
\text { is under local jurisdiction } \\
\text { Fire safety to sendout } \\
\text { Approve design and opera- } \\
\text { tion of dock facil ities }\end{array}$ & $\begin{array}{l}\text { Ports and Water- } \\
\text { ways Safety Act } \\
\text { of 1972: } 33 \\
\text { U.S.C. 1221 et } \\
\text { seq. (Supp 1972) } \\
\text { Magnuson Act: } \\
50 \text { U.S.C. } 191 \\
\text { Ex. Odr. 10173 } \\
\text { Dangerous Cargo } \\
\text { Act of 1970: } 46 \\
\text { U.S.C. } 170 \text { (1970) } \\
\text { Tanker and Vessel } \\
\text { Safety Act of } \\
\text { 1978 } \\
\text { Federal Water } \\
\text { Pollution } \\
\text { Control Act }\end{array}$ \\
\hline
\end{tabular}


TABLE 2-2. CONTINUED

\begin{tabular}{|c|c|c|c|}
\hline Organization & Documentation & Responsibility & Authority \\
\hline $\begin{array}{l}\text { Department of } \\
\text { Transportation - } \\
\text { (USCG) (Cont.) } \\
\qquad \\
\ldots\end{array}$ & & $\begin{array}{l}\text { Approve design of private } \\
\text { aids to navigation } \\
\text { Regulate oil transfer } \\
\text { operations } \\
\text { Regulate security of all } \\
\text { facilities. }\end{array}$ & i \\
\hline $\begin{array}{l}\text { Department of } \\
\text { Transportation - } \\
\text { Federal Aviation } \\
\text { Administration }\end{array}$ & . & $\begin{array}{l}14 \text { CFR } 139.1,139.5 \text {. } \\
\text { Review terminal design for } \\
\text { possible aviation hazard. }\end{array}$ & \\
\hline $\begin{array}{l}\text { Department of } \\
\text { Commerce - National } \\
\text { Bureau of Standards }\end{array}$ & & $\begin{array}{l}\text { Review engineering } \\
\text { of cryogenic systems. }\end{array}$ & \\
\hline $\begin{array}{l}\text { Department of } \\
\text { Commerce - } \\
\text { U.S. Maritime } \\
\text { Administration }\end{array}$ & & $\begin{array}{l}\text { Provide financial aids for } \\
\text { construction and operation } \\
\text { of U.S. flag tankers. }\end{array}$ & \\
\hline $\begin{array}{l}\text { Department of } \\
\text { Defense - Corps } \\
\text { of Engineers (COE) }\end{array}$ & $\begin{array}{l}\text { Permits for radio } \\
\text { towers and opera- } \\
\text { tion. }\end{array}$ & $\begin{array}{l}\text { Certify communications } \\
\text { equipment }\end{array}$ & \\
\hline
\end{tabular}


TABLE 2-2. CONTINUED

\begin{tabular}{|c|c|c|c|}
\hline Organization & Document at ion & Responsibility & Authority \\
\hline $\begin{array}{l}\text { Department of Commerce } \\
\text { National Bureau of } \\
\text { Standards }\end{array}$ & $\therefore$ & $\begin{array}{l}\text { Set generic standards } \\
\text { for cryogenic handling } \\
\text { equipment }\end{array}$ & \\
\hline $\begin{array}{l}\text { Department of } \\
\text { Agriculture }\end{array}$ & $\begin{array}{l}\text { Permits for right-of- } \\
\text { way through National } \\
\text { Forest }\end{array}$ & $\cdot \cdot \cdot$ & . \\
\hline $\begin{array}{l}\text { Department of } \\
\text { Interior }\end{array}$ & & $\begin{array}{l}\text { Approve right-of-way } \\
\text { on federa! lands. } \\
\text { Review EIS. }\end{array}$ & . \\
\hline $\begin{array}{l}\text { Nuc.lear: Regulatory } \\
\text { Commission }\end{array}$ & $\therefore$ & $\begin{array}{l}\text { Review siting with respect } \\
\text { to proximity to nuclear } \\
\text { facilities. }\end{array}$ & : \\
\hline $\begin{array}{c}\text { Environmental } \\
\text { Protection Agency } \\
\qquad\end{array}$ & $\begin{array}{l}\text { Permits for waste water } \\
\text { discharges }\end{array}$ & $\begin{array}{l}\text { Review air, water, and } \\
\text { noise impact on environ- } \\
\text { ment. } \\
\qquad .\end{array}$ & $\begin{array}{l}\text { Federal Water } \\
\text { Pollution Control } \\
\text { Act of 1972: } \\
33 \text { U.S.C. } \\
\text { \$1251 et seq. } \\
\text { (supp 1972) } \\
\text { (PL } 91-90) \text {. } \\
\text { National } \\
\text { Environment al } \\
\text { Protect ion. Act } \\
\text { of } 1969: \\
42 \text { U.S.C. } \$ 4321 \\
\text { et seq. (1970) } \\
\text { (PL } 91-90) .\end{array}$ \\
\hline
\end{tabular}


TABLE 2-2. CONCLUDED

\begin{tabular}{|c|c|c|c|}
\hline Organization & Document ation & Respons ibility & Authority \\
\hline $\begin{array}{l}\text { Environment al } \\
\text { Protect ion Agency } \\
\text { (Cont.) }\end{array}$ & & . & $\begin{array}{l}\text { Clean Air Act } \\
\text { (PL 88-206 and } \\
\text { amendment). } \\
\text { Rivers and } \\
\text { Harbors Act } \\
\text { of } 1899 \\
(P L 92-500) .\end{array}$ \\
\hline $\begin{array}{l}\text { Occupational Safety } \\
\text { and Health } \\
\text { Administration }\end{array}$ & $\begin{array}{l}\text { Certificate of } \\
\text { Sanitation }\end{array}$ & $\begin{array}{l}\text { Review design } p l \text { ans and } \\
\text { construction for preven- } \\
\text { tion of communicable } \\
\text { diseases and deratization }\end{array}$ & 1 \\
\hline Export/Import Bank & . & $\begin{array}{l}\text { Make loans to governments } \\
\text { to support purchase of U.S. } \\
\text { goods for constructing } \\
\text { facilities. }\end{array}$ & $\cdots$ \\
\hline
\end{tabular}

applies to import-export activities, in addition to the usual OSHA responsibilities for industrial activities. 
functions pertaining to pipeline safety. The roles of these five key organizations are depicted in Table 2-3.

Under the Energy Act, the FERC has become the focal point for environmental and safety evaluations and approvals. It exercises this responsibility under the authority of 'Section 7 of the Natural Gas Act of 1938 and the provisions of 18 CFR 153. The FERC's evaluation, which is site-specific, is preceded by an evaluation by the ERA of the consistency of a proposed project with the public interest. This review examines questions of need for the supply, international and national economics, pricing, comparison with alternatives, and contingency planning. The division of responsibility between the ERA and the FERC was enunciated by the secretary of Energy ${ }^{-}$in separate Delegation orders to these organizations. In essence, the FERC was delegated all the responsibilities formerly'held by the FPC, except the Section 3 responsibilities of the Natural Gas Act that were delegated to the ERA.

A report prepared by the Battelle Memorial Institute (Ref. 2-4) summarizes this division of responsibility between the FERC and the ERA. The FERC has the responsibility for:

- Issuing and enforcing certificates for the construction, extension or operation of natural gas transportation and storage facilities.

- Issuing certificates authorizing the sale of natural gas for resale purposes.

- Investigating and establishing the rates and charges for natural gas transported or sold for resale in interstate commerce, inciuding curtailments of services during gas shortages.

- Approving interstate pipeline curtailments.

- Establishing and enforcing well-head natural gas prices (the price before transportation costs). 
TABLE 2-3. MAJOR REGULATORY RESPONSIBILITIES

FOR LNG FACILITIES

\begin{tabular}{|c|c|c|c|}
\hline Area of responsibility & $\begin{array}{l}\text { Set standarids } \\
\text { or criteria }\end{array}$ & Permitting & Enforcement \\
\hline Import order & DOE-ERA & DOE-ERA & $N / A$ \\
\hline $\begin{array}{l}\text { Approval of plans for construction } \\
\text { and operation } \\
\text { Import terminal } \\
\text { Interstate distribution } \\
\text { Intrastate distribution }\end{array}$ & State & $\begin{array}{l}\text { DOE-FERC } \\
\text { DOE-FERC } \\
\text { State }\end{array}$ & State \\
\hline $\begin{array}{l}\text { Dredging or building in waterways } \\
\text { and wetlands }\end{array}$ & $D O D-C O E$ & $D O D-C O E$ & DOD-COE \\
\hline Safety regulations & & • & \\
\hline Vessel & DOT-CG & $\mathrm{DOT}-\mathrm{CG}$ & DOT-CG \\
\hline Terminal & DOT-CG & $\begin{array}{c}\text { (S411 would, give preconstruction } \\
\text { approval to DOT-MTB) }\end{array}$ & \\
\hline On-land pipelines & DOT-MTB & & DOT-MTB \\
\hline
\end{tabular}

${ }^{a}$ States are certified by DOT-MTB to administer LNG safety in accordance with applicable CFRs. 
- Regulating power/gas mergers and security acquisitions.

The FERC does not, however, have jurisdiction over gas distribution. The ERA is in charge of:

- Establishing curtailment priorities for and authorizing the import or "export"of natural gas.

- Establishing emergency interconnections between pipelines.

- Developing standby and emergency programs for energy materials.

The Battelle report also discusses part of the DOT's responsibilities:

Safety regulation of natural gas pipelines was established by the Natural Gas Pipeline. Safety Act of 1968 and is the responsibility of the opso." Unlike economic regulations, safety regulations apply to both inter- and. intra-state natural gas pipelines. However, the OPSO does allow state agencies with approved safety programs to maintain responsibility for: their intrastate transmission and distribution lines. In some cases, state agencies may also participate jointly with the OPSO in regulating the safety aspects of interstate pipelines.

New OPSR safety standards were published.on. 11 . February 1980. These are based in part on the National Fire Protection Association (NFPA) standard 59A (1979 Edition), and in part on its own standards (see Section III, p. 3-1). Compliance of proposed plans with these standards is evaluated by OPSR, which office has the opportunity to make its evaluation known to the FERC, but is not required to do so by law. A proposed

* Office of pipeline safety operations, within the DOT's MTB, recently renamed the office of pipeline safety Regulation (OPSR). 
bill, S411, 95th Congress, would require preconstruction approval by the OPSR.

The U.S. Coast Guard, also a part of the DOT, controls harbor traffic and may approve or deny entry of U.S. or foreign vessels to U.S. waterways and ports. Approval for entry takes into account, among other considerations, vessel design and construction, state of vessel maintenance, crew training and qualification, and ship manning requirements. The Captain of the Port acts on behalf of the USCG in assessing these factors. He also exercises control over the port on the basis of operating conditions, including weather, and determines the number of escorts required. The coast Guard is also responsible for fire safety and security of harbor operations, which includes ensuring the adequate storage and regasification areas of marine LNG terminals.

The COE is responsible for the evaluation of construction plans in rivers, harbors, and wetlands and for ensuring compliance with the Coastal zone Management Act of 1972. The Coastal zone Act calls for approval of such projects by state and local governments prior to the issuance of construction permits. Thus, although the COE has made it a practlce to defer to the FERC in the preparation of the Environmental Impact statements (EIS), this agency has a key responsibility in ensuring coordination among different levels of government for projects in coastal zones. LNG terminals usually fall within this category.

b. The permitting process--The sequence in which the ERA and the FERC exercise their responsibilities is as follows: *

\footnotetext{
* This sequence is the ideal. In practice, the ERA/FERC
} interface is not as clear as described here. 
- Applications to import LNG are made to the ERA. After the ERA reviews the application for an Import order, with or without an oral Argument, at its discretion it makes its recommendation known to the FERC.

- With a positive indication from the ERA that a proposed import project is in the public interest or upon receipt of an application for interstate resale of natural gas not under ERA's jurisdiction, the FERC staff prepares the EIS, coordinates with other interested government agencies, holds hearings, and presents all collected evidence to an Administrative Law Judge.

- The Administrative Law Judge makes a recommendation, often with conditions, to the commissioners.

- If the Commission rules in favor of the project, the ERA issues the order to Import for international projects and the FERC grants a certificate of Public Convenience and Necessity for interstate activities.

The review by the FERC and the hearing process provide the opportunity to integrate evaluations by other government agencies, state and local governments, and intervenors. In general, it is the responsibility of the other agencies to take the initiative to make their positions known to the FERC. Figure 2-l illustrates this integration process. A comprehensive list of federal permits required for typical LNG projects is given in Table $2-4$.

The Coast Guard has direct authority for approval of vessels to enter U.S. waterways. Ships not meeting its safety standards are not granted entry. It exercises this responsibility by inspecting vessels that request entry to U.S. harbors 


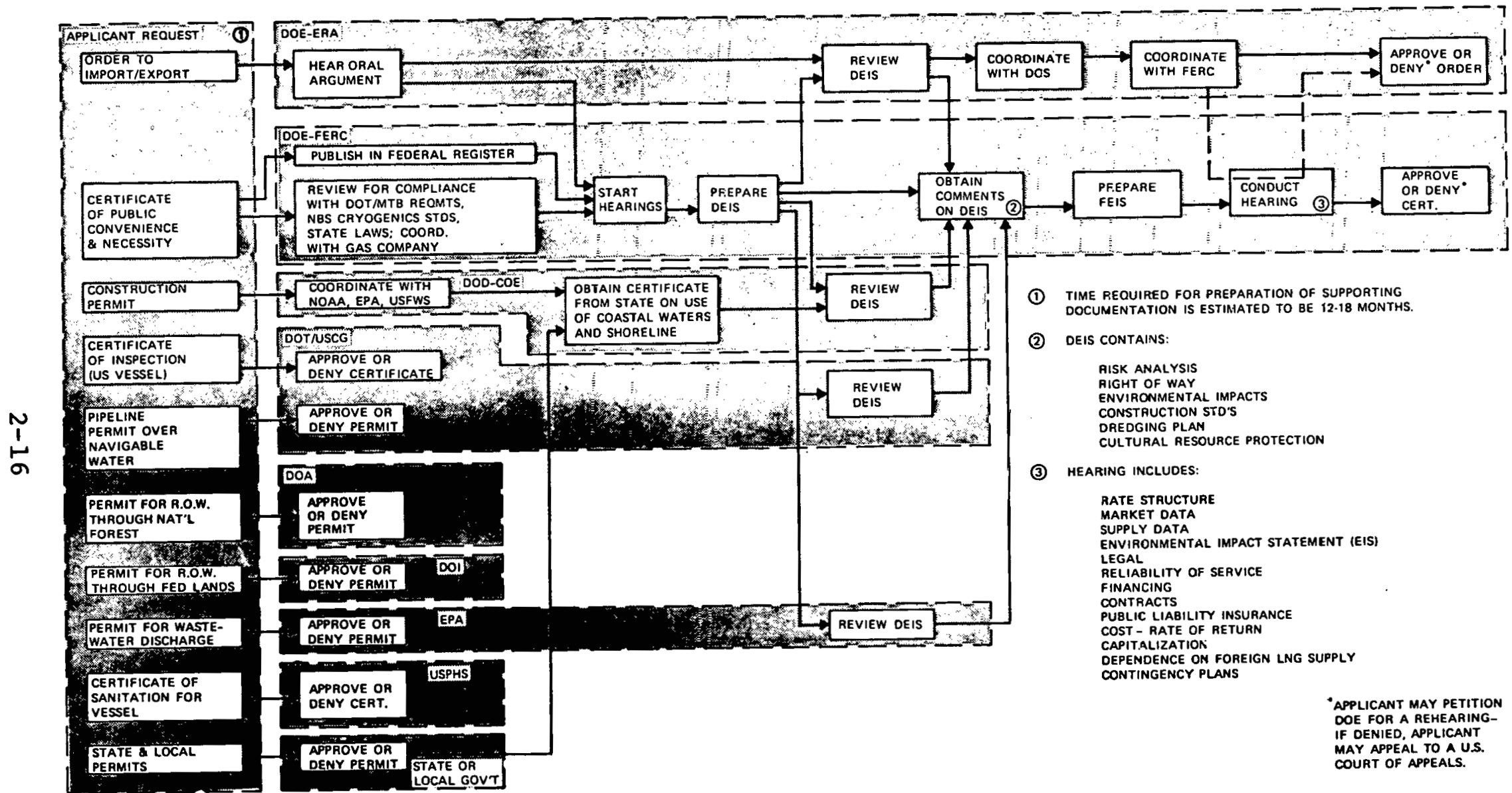

Figure 2-1. Flow chart: LNG licensing/permitting sequence. 
TABLE 2-4. SUMMARY OF FEDERAL REQUIREMENTS FOR PERMITS

FOR LNG FACILITIES AND OPERATIONS

\begin{tabular}{|c|c|c|c|c|c|c|c|}
\hline Application & Content & $\begin{array}{l}\text { Agenc } \\
\text { From }\end{array}$ & cy & $\begin{array}{l}\text { Coordinating } \\
\text { agency }\end{array}$ & $\begin{array}{l}\text { Basis of } \\
\text { evaluation }\end{array}$ & Prerequisites & Time \\
\hline $\begin{array}{l}\text { Order for } \\
\text { Import/Export } \\
\text { - Natural Gas } \\
\text { Act } 1938 \$ 3 \\
\text { - } 18 \text { CFR } 153 \\
\\
\text { (International } \\
\text { transfers) }\end{array}$ & $\begin{array}{l}\text { - Articles of } \\
\text { incorporation } \\
\text { of applicant } \\
\text { - State and local } \\
\text { authorizations } \\
\text { - Ownership, } \\
\text { officials } \\
\text { - Total gas } \\
\text { supply data } \\
\text { - Market data } \\
\text { - Pricing } \\
\text { - Design, eng'g, } \\
\text { constr. plans } \\
\text { - Maps--location } \\
\text { of facilities } \\
\text { - EIR } \\
\text { - Facts on which } \\
\text { public conven- } \\
\text { ience is based } \\
\text { - Producer/seller } \\
\text { contracts }\end{array}$ & 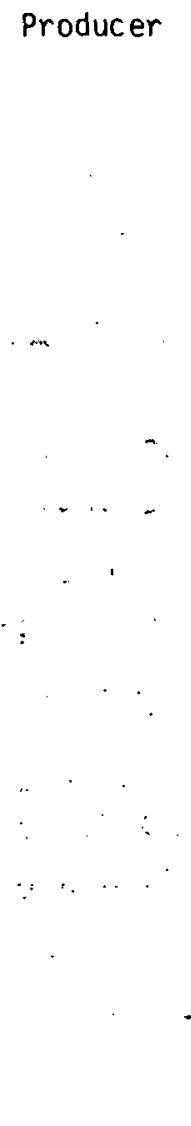 & 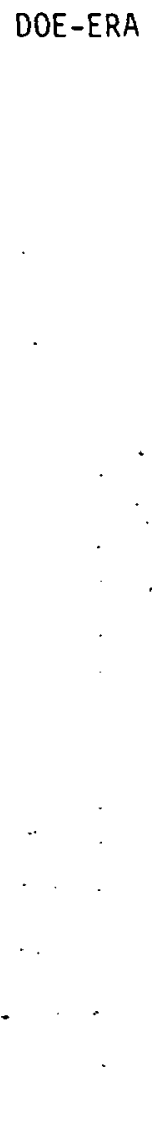 & DOS & $\begin{array}{l}\text { - Verify accepta- } \\
\text { bility to gas } \\
\text { companya } \\
\text { - Notice in } \\
\text { Federal } \\
\text { Register } \\
\text { - EIS (prepared } \\
\text { by COE or FERC) } \\
\text { - Assüre com- } \\
\text { pliance with } \\
\text { DOT-MTB } \\
\text { regulations } \\
\text { - Verify com- } \\
\text { pliance with } \\
\text { state laws } \\
\text { - Oral argument } \\
\\
\therefore\end{array}$ & $\begin{array}{l}\text { DE IS-Comments- } \\
\text { FEIS }\end{array}$ & 4-6 months \\
\hline
\end{tabular}

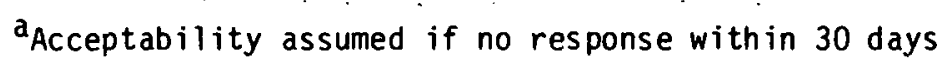


TABLE 2-4. CONTINUED

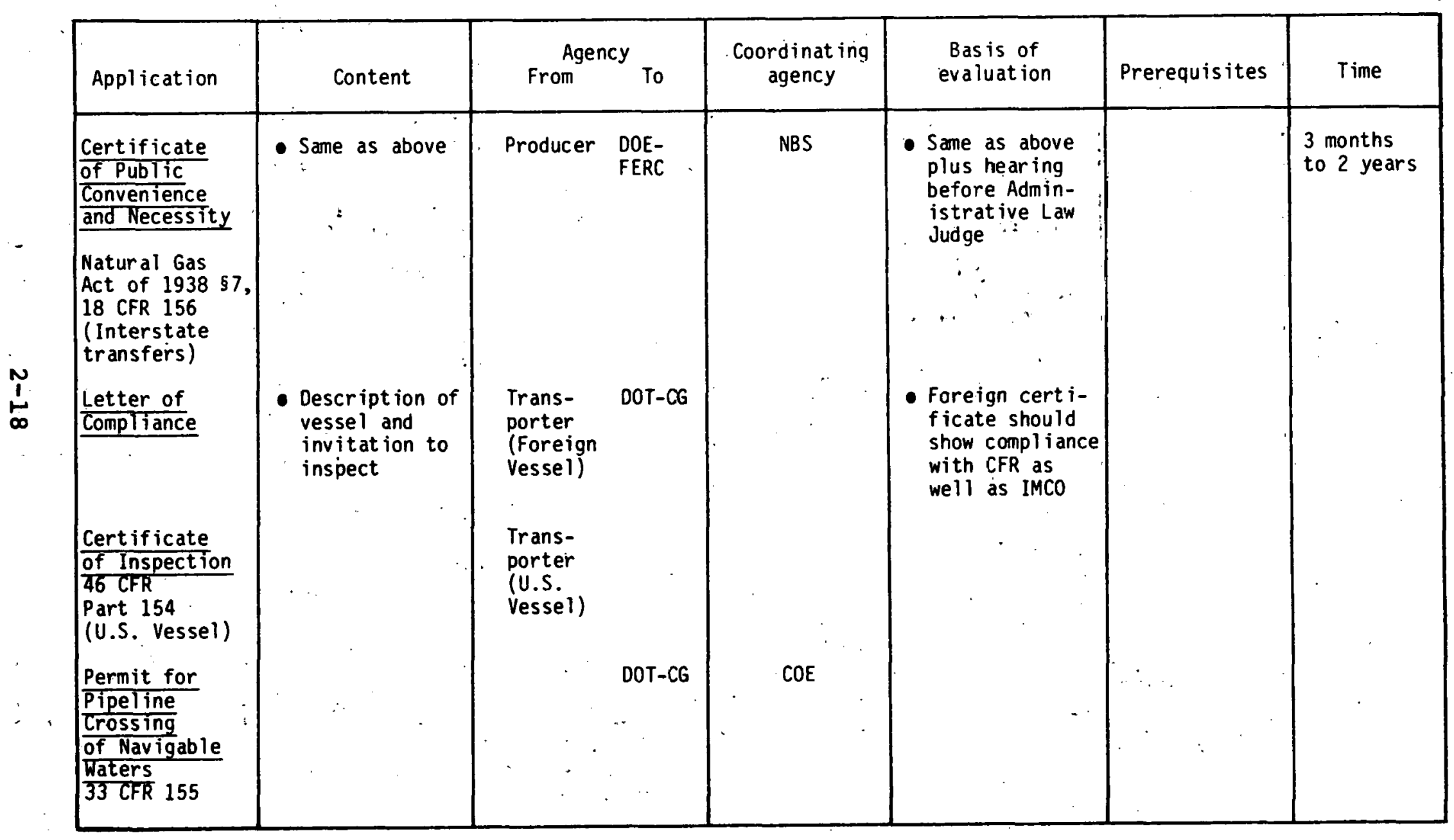


TABLE 2-4. CONTINUED

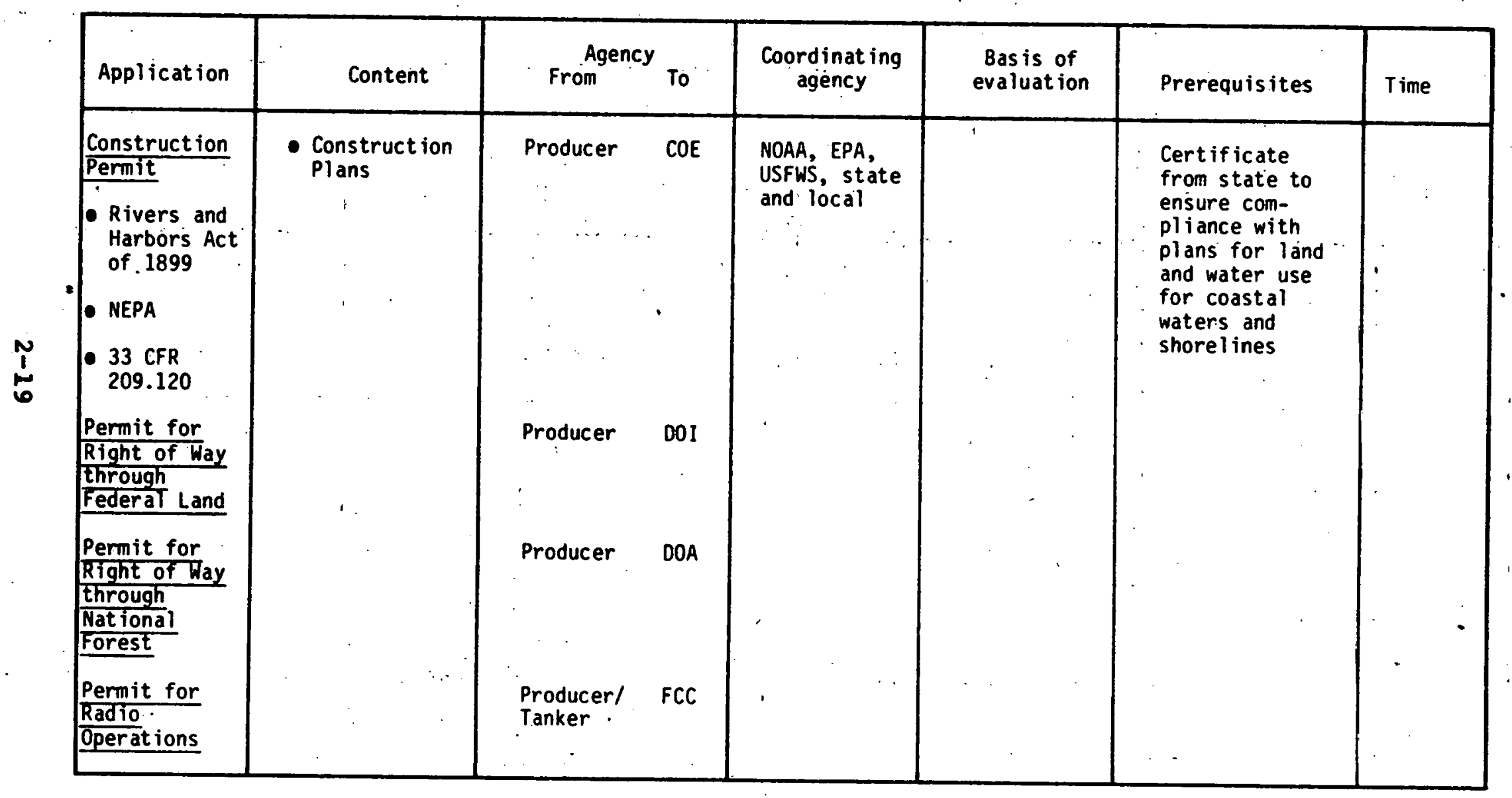


TABLE 2-4. CONCLUDED

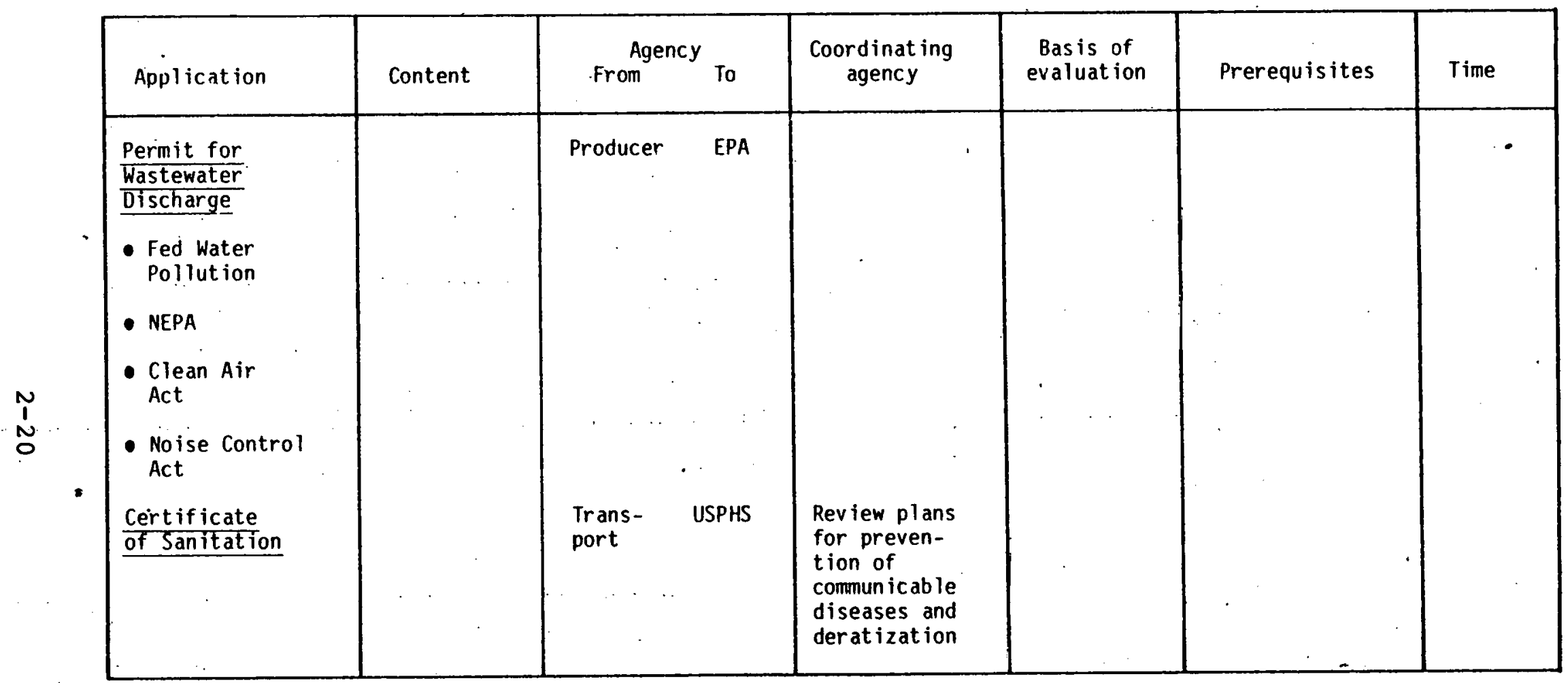


and by forbidding such entry until a Letter of Compliance (which takes into account the several aspects discussed above) has been issued.

The COE has direct authority under the Rivers and Harbors Act of 1899. Construction or operations involving dredging or construction in waterways (to the high tide mark) or on wetlands require a permit from the COE. Under CFR 33, the COE is required to evaluate environmental factors and to exercise coordination with other federal agencies, as well as state and local governments before granting such a permit.

For LNG terminals, the COE has on at least one occasion taken the position that the EIS should be prepared by the FERC. Moreover, the COE places its review in series with that of the ERA on the basis that it wishes to spare the expense of evaluations of projects which might later be denied.

The EIS is prepared in accordance with the National Environmental policy Act. It examines impacts on fish and wildlife, and on recreational, scenic, archaeological, and historical values; estimates emissions; estimates contributions to energy conservation; reviews plans for disposal of dredge material; and analyzes the probabilities of water spills and the consequences of land or water spills. The FERC does not estimate the probabilities of accidents in land-based facilities, but focuses instead on the potential consequences of a spili-however smallits probability of occurrence.

The regulations pursuant to both the Rivers and Harbors Act of 1899 and the Natural Gas. Act of 1938. require applicants to seek compliance with state and local requirements. States in some cases have approval powers under the Federal Coastal zone Management Act. It is not. clear that the federal government insists on actual compliance at these levels. For example, the western LNG project was granted conditional 
approval by the DOE before it was approved by California; however, the Administrator's opinion held that state and local governments should have an opportunity to decide on the site, adding "we can, of course, reconsider at a later date whether federal jurisdiction should be exercised exclusively - . ." (Ref. 2-10). In another case, the FPC was more specific in making its approval of the Trunkline LNG Project (29 April 1977) contingent upon receipt of all state and local approvals.

In addition to the permits from the federal government, applicants typically require a large number of permits from state and local agencies. For the Cove Point, Maryland, LNG terminal, for example, over one hundred such permits were obtained in the course of construction (Refs. 2-2, 2-11).. Many were not LNG-specific, but covered such activities as:

- Compliance with building codes.

- Compliance with vehicle codes.

- Protection of fish and wildlife.

- Preservation of the environment.

- Protection of cultural and historic values.

- Herbicidal controls.

- Vocational health and safety standards.

- Regulation of utilities.

- Fiscal management.

- Protection of natural resources.

- Disaster preparedness.

- Land use and zoning.

- Protection of rights-of-way.

- Management of waste.

- Excavation and fill.

- Water management.

- Fire protection.

- Sediment and erosion control. 
No generalization can be made as to the time consumed in obtaining all required state and local permits; however, most are obtained in a matter of days or weeks when applications reflect compliance with prevailing codes. When variations are sought, it may take months, even years, to obtain approvals.

The activity path which determines the time from the initial decision to undertake a project to import LNG for interstate sale until all permits are granted is, in sequence:

- Applicant's preparation of materials required to substantiate the application, including an Environmental Impact Report.

- The ERA's evaluation under Section 3 of the Natural Gas Act.

- The FERC's evaluation under section 7 of the Natural Gas Act.

- The COE's evaluation under the Rivers and Harbors Act.

The COE's evaluation would probably parallel that performed by the FERC once the ERA endorses a proposed project; however, there is no legal requirement that the CoE issue permits for construction as a direct consequence of a decision by the FERC to grant a Certificate of Public Convenience and Necessity. Nor is the FERC's Certificate a legal prerequisite to the COE's permit.

Preparation of the application itself takes from 1 to 1-1/2 years on the part of the applicant. There is little history on which to base an estimate of the time required for ERA's evaluation. In the El Paso Company's Algeria II project, the length of time from first notice of an oral Argument until a decision was rendered was nine months. The review by the FERC can be as short as three months or as long as two years. Typical cases take nine months to one year. The COE requires 
about one year when acting as the lead agency for the EIS; when the FERC acts as the lead, this period would be somewhat shorter and in part parallel with the ERA's evaluation. Overall, then, the federal permitting process takes, on the average, three to four years. State and local approvals may add substantially to this lead time, especially when proposed siting becomes a public concern as it did in the Western LNG Terminal Associates' project.

\section{CASE HISTORIES}

a. LNG terminals--LNG terminals are facilities for liquefying and shipping LNG, for receiving and storing LNG transported to the United states in tankers, and for vaporizing LNG for sendout via pipelines to customers. The federal government has approved such facilities at Kenai, Alaska; Everett, Massachusetts; Cove Point, Maryland; Savannah, Georgia; and Lake Charles, Louisiana. Applications are pending for two additional terminals, one for Indonesian gas and one for Algerian gas. These applications are reviewed in the following sections.

(1) El Paso Company's Algeria II Project (Refs. 2-12, 2-13)**--On 15 october 1976, El Paso Eastern Company applied*** for an order to Import LNG pursuant to section 3 of the Natural

\footnotetext{
*The Alaska terminal is for export of LNG to Japan. It is.. interesting to note that until very recently, the U.S. was a net exporter of LNG. Until the Cove Point and the El paso facilities went into operation, the U.S. was importing only about half as much LNG as it was exporting from Alaska.

**Also, private communication from L. Dell 'Osso, Jr.., General Manager, El Paso LNG Terminal Company, April.24, 1979.

*** The application was in the form of an amendment to a previous submittal. El Paso Eastern had not secured the required permits before the expiration of its contract with the Algerian supplier, Sonatrach. That contract had expired on December 31, 1973, and Sonatrach exercised its option to withdraw
} 
Gas Act. El Paso Eastern, a wholly-owned subsidiary of El Paso LNG Company, would purchase LNG from another subsidiary, El Paso Atlantic Company. El Paso Eastern would arrange, through a third subsidiary, El Paso LNG Terminal Company, for the receipt, storage and vaporization of the LNG, and delivery of the vaporized gas to El Paso Natural Gas Company. El Paso Natural Gas Company would buy 65 percent of the vaporized gas from El Paso Eastern and resell it to its customers, 80 percent of whom would be in California. Thus, about half of the imported gas would be pipe-lined from Texas to California. Thirty-five percent of the gas would be sold to United LNG Company, a wholly-owned subsidiary of United Gas Pipe Line Company.

The flow of gas from Sonatrach in Algeria through the El Paso LNG Company subsidiaries to customers is shown in Figure 2-2. Interestingly, gas and title thereto would not always flow together. El Paso Eastern apparently would act as a broker and own no gas-handling facilities. El paso LNG Terminal Company would receive, store, and transfer gas without transfer of title.

during 1974. Sonatrach invited El Paso to renegotiate. Upon Sonatrach's withdrawal, El Paso cancelled its contracts with its customers. El Paso's renegotiation with Sonatrach was completed 28 October 1975, but by that time El Paso was unable to renegotiate with its customers. El Paso requested that proceedings be suspended. An oral hearing was held on 14 July 1976 and EI Paso was directed to file a progress report on 15 october 1976. By that time, El Paso had negotiated a new contract to supply gas to its affiliate, El Paso Natural Gas Company, and to United Gas Pipe Line Company, and the amended application was filed. 


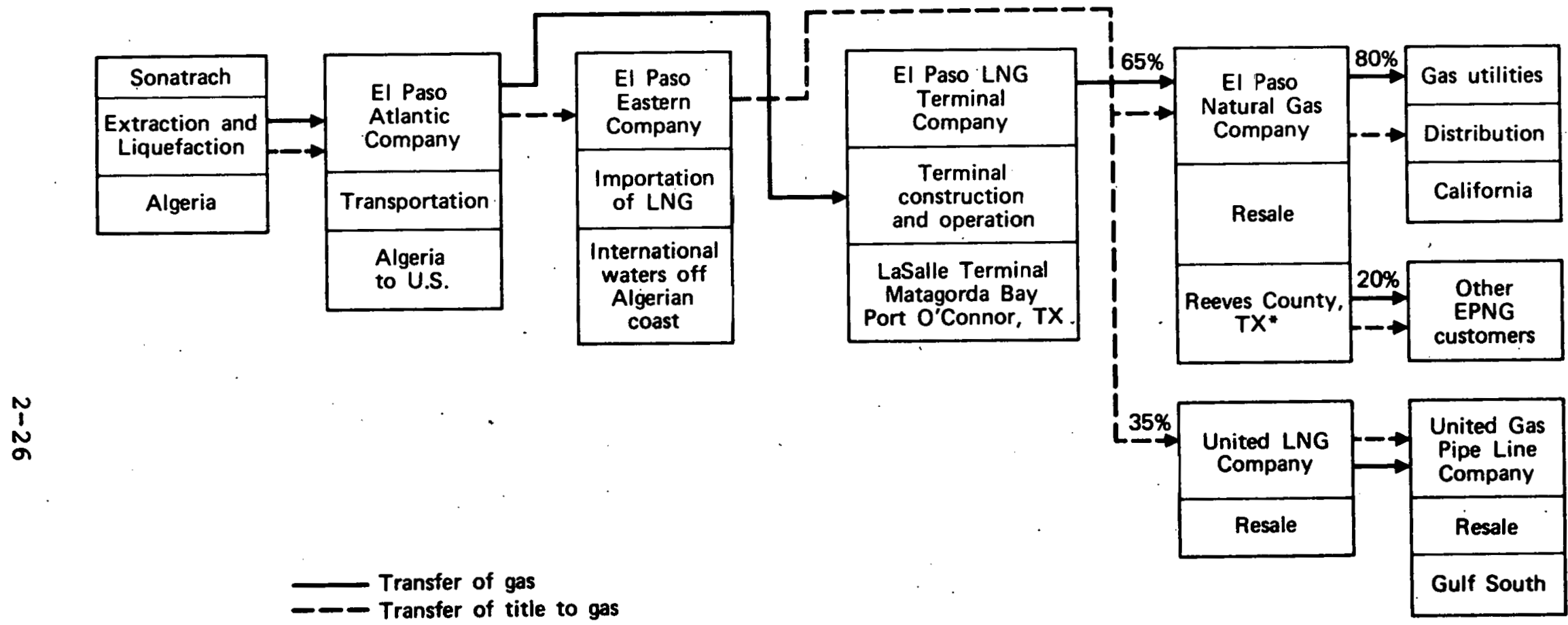

- EI Paso Natural Gas would build 463 miles of pipeline from terminat to Reeves County, including 31 miles to the UGP line near Victoria, Texas.

Figure 2-2. Corporate arrangements for Algeria II project. 
El Paso Atlantic Company was formed to transport LNG from Algeria to the United states. It would operate twelve vessels, six to be provided by El Paso Atlantic and six to be provided by Sonatrach. The operators of the vessels would apply for certificates and permits pertaining to bringing LNG into U.S. waterways and ports.

An application for an order to Import under section 3 of the Natural Gas Act was made by El Paso Eastern, as well as for certificates of public convenience and necessity and applications for the sale of vaporized LNG under section 7 of the Act. An application for the certificate of Public Convenience and for construction of the Lasalle Terminal at Matagorda Bay near Port O'Connor, Texas, was made by El Pasó LNG Terminal. The characteristics of the system are summarized in Table 2-5.

TABLE 2-5. CHARACTERISTICS OF EL PASO COMPANY'S ALGERIA II PROJECT

\begin{tabular}{ll|}
\hline Import rate & 1 billion scf/day \\
Start - year & 1983 \\
Term of contract & 20 years \\
Number of tankers & 12 \\
Tanker capacity & $125,000 \mathrm{~m}^{3} / \mathrm{vessel}$ \\
Terminal: & 2 \\
$\quad$ Number of tanker berths & $300,000 \mathrm{~m}^{3}$ \\
LNG storage capacity & $29.675 \times 10^{6} \mathrm{~m}^{3} / \mathrm{d}$ \\
LNG vaporization capacity & \\
* &
\end{tabular}


During 1977, the FPC prepared and offered for comment the Draft EIS for the project, obtained comments, and published the Final EIS. By the time the Administrative Law Judge rendered his decision on the El Paso II Project on 25 October 1977, the new DOE had been created and jurisdictional responsibility for administration of the Natural Gas Act had been divided between the FERC, the successor of the FPC and the ERA. The project was approved by the Administration Law Judge at the FERC; however, the record was ordered transferred to the ERA for review under section 3 of the National Gas Act before final FERC action under section 7.

The ERA called for an oral Argument under section 3 which was heard in April 1978. The application was subsequently denied and the denial was documented in ERA Opinion Number Four on 21 December 1978. Between the time of the oral Argument and the denial, the ERA declared its intent to prepare a Supplemental EIS to cover topic areas which it felt were not adequately addressed in the FPC's Final EIS.

The essence of ERA's denial of the application was that in their opinion it failed to meet the statutory test that the project is "not inconsistent with the public interest." In ERA's opinion, the proposed project was therefore neither neutral nor consistent--it was inconsistent--with the public interest. The following factors were cited in the conclusion:

- The Proposed project failed to satisfy ERA's presumption in favor of direct sales by importing companies (in this case El Paso Eastern) to gas distribution utilities (in this case Southern California Gas Company, Pacific Gas and Electric Company and customers of United Gas Pipe Line Company). 
- No overriding national or regional need for the gas was found; one LNG import project (Pacific Indonesia) which would supply LNG directly to distributors who would receive half of the Algeria II LNG (Western LNG) had previously been conditionally approved; other proximate sources for Algeria II LNG customers were considered probable; the Energy Act would alleviate demand through conservation and solar provisions.

- Referring to ERA Opinion Number Three, it was noted that full account must be taken of proximate supply opportunities before sharply increasing U.S. dependence on LNG imports.

- The price escalation formula was considered to have serious problems.

- The applicant's contingency plan for supply shortages was considered to be inadequate.

In summary, ERA's principal grounds for the denial were (1) the project structure with respect to resale, (2) the pending, partially overlapping Pacific Indonesia LNG project, (3) increased U.S. dependence on foreign energy supplies, (4) the price formula, and (5) the contingency plan. The conclusion made no reference to adverse environmental impacts or to public risk with respect to LNG safety. The opinion was rendered without prejudice to future mutually beneficial opportunities for international gas trade.

On 19 January 1979, El Paso Eastern petitioned for a rehearing of Opinion Number Four. ERA granted the petition on 20 February 1979, and announced it would issue a further order on the rehearing. On 25 October 1979, the ERA held a public conference in Houston to discuss the issues and procedures to be followed in the rehearing. They also stated that the date of the rehearing and issuance of the procedures to 
be followed will be set forth following completion of the present ERA workload.

The chronology of the applications for the Algeria II Project is given in Table 2-6.

(2) Western LNG Terminal Associates' Project (Ref. 2-14, 2-15) *-Western LNG Terminal Associates is a partnership of two gas distribution utilities in California-Pacific Gas and Electric Company (PG\&E) and the Southern California Gas Company, a subsidiary of the Pacific Lighting corporation. The proposed project would import natural gas in liquefied form from the Republic of Indonesia and the cook Inlet area of Alaska to a terminal near Point Conception on the California coast. A contract for purchase of LNG over a period of twenty years from the Indonesian supplier, Pertamina, was signed in september 1973. Ultimately, 500 million standard cubic feet (scf) per day of Indonesian gas and $400 \mathrm{million}$ scf/day of Alaskan gas would be imported. Peaking capacity of the regasification plant could increase sendout by another $300 \mathrm{million}$ scf/day, for a total maximum sendout of $1200 \mathrm{mili}$ ion scf/day.

The corporate structure for liquefaction, purchase, transport, receipt, sendout, and resale of the Indonesian and Alaskan supplies is summarized in Table 2-7. All LNG gasified and sent out from the western LNG Terminal would be bought and resold in equal volumes to customers by Southern California Gas Company and PG\&E.

The critical paths for the permitting process for the project are:

- Obtaining an order to Import from the ERA for PacIndonesia to import gas from Indonesia.

- Obtaining a Certificate of Public Convenience and Necessity from the FERC for the Western Terminal

\footnotetext{
*Also, private communication from J. Garcia (Western LNG Terminal Associates), 21 June 1979. 
TABLE 2-6. CHRONOLOGY OF EVENTS--AĹGERIA II PROJ̈ECT APPLICATION FOR LASALLE TERMINAL

\begin{tabular}{|c|c|}
\hline Date & Item \\
\hline $4 / 4 / 73$ & Applications for El Paso--Algeria II project filed. \\
\hline $12 / 31 / 73$ & $\begin{array}{l}\text { Sonatrach option to cancel if project approvals not } \\
\text { obtained. }\end{array}$ \\
\hline 1974 & $\begin{array}{l}\text { Original contract cancelled by Sonatrach. El Paso } \\
\text { Algeria cancelled contracts with its customers. }\end{array}$ \\
\hline $10 / 28 / 75$ & $\begin{array}{l}\text { Renegotiated contract with Sonatrach ( } 4 / 30 / 77 \text { approval } \\
\text { cutoff; } 12 / 31 / 77 \text { financing cutoff). }\end{array}$ \\
\hline $7 / 14 / 76$ & Oral hearing on suspension of project. \\
\hline $10 / 15 / 76$ & $\begin{array}{l}\text { Progress report ordered at oral hearing--contacts between } \\
\text { EL Paso Eastern (formerly El Paso Algeria) and customers } \\
\text { negotiated amendment to. application for order pursuant to } \\
\text { Section } 3 \text { of Natural Gas Act. }\end{array}$ \\
\hline $3 / 1 / 77$ & $\begin{array}{l}\text { Applications filed for Certificates of Public Convenience } \\
\text { and Necessity (included three-volume Joint Environment } \\
\text { Report prepared by participants). }\end{array}$ \\
\hline $4 / 1 / 77$ & Participants file Joint LNG Safety Report. \\
\hline $4 / 14 / 77$ & $\begin{array}{l}\text { Order consolidating proceedings; terminate consolidated } \\
\text { proceedings; grant requests to withdraw and dismiss cer- } \\
\text { tain applications; provide for hearing, prescribe proce- } \\
\text { dures, and require payment of filing fees and notice of } \\
\text { new docket designations. }\end{array}$ \\
\hline $4 / 25 / 77$ & Prehearing conference. \\
\hline $4 / 27 / 77$ & $\begin{array}{l}\text { Presiding Judge--Notice of Hearing and other procedural } \\
\text { dates. }\end{array}$ \\
\hline $4 / 29 / 77$ & FPC--notice clarifying filing procedures. \\
\hline $\begin{array}{l}5 / 17 / 77- \\
5 / 23 / 77\end{array}$ & Five-day heárings on nonenvironmental issues. \\
\hline $6 / 3 / 77$ & $\begin{array}{l}\text { Application by El Paso Terminal to Corps of Engineers } \\
\text { for construction permit. }\end{array}$ \\
\hline
\end{tabular}


TABLE 2-6. CONTINUED

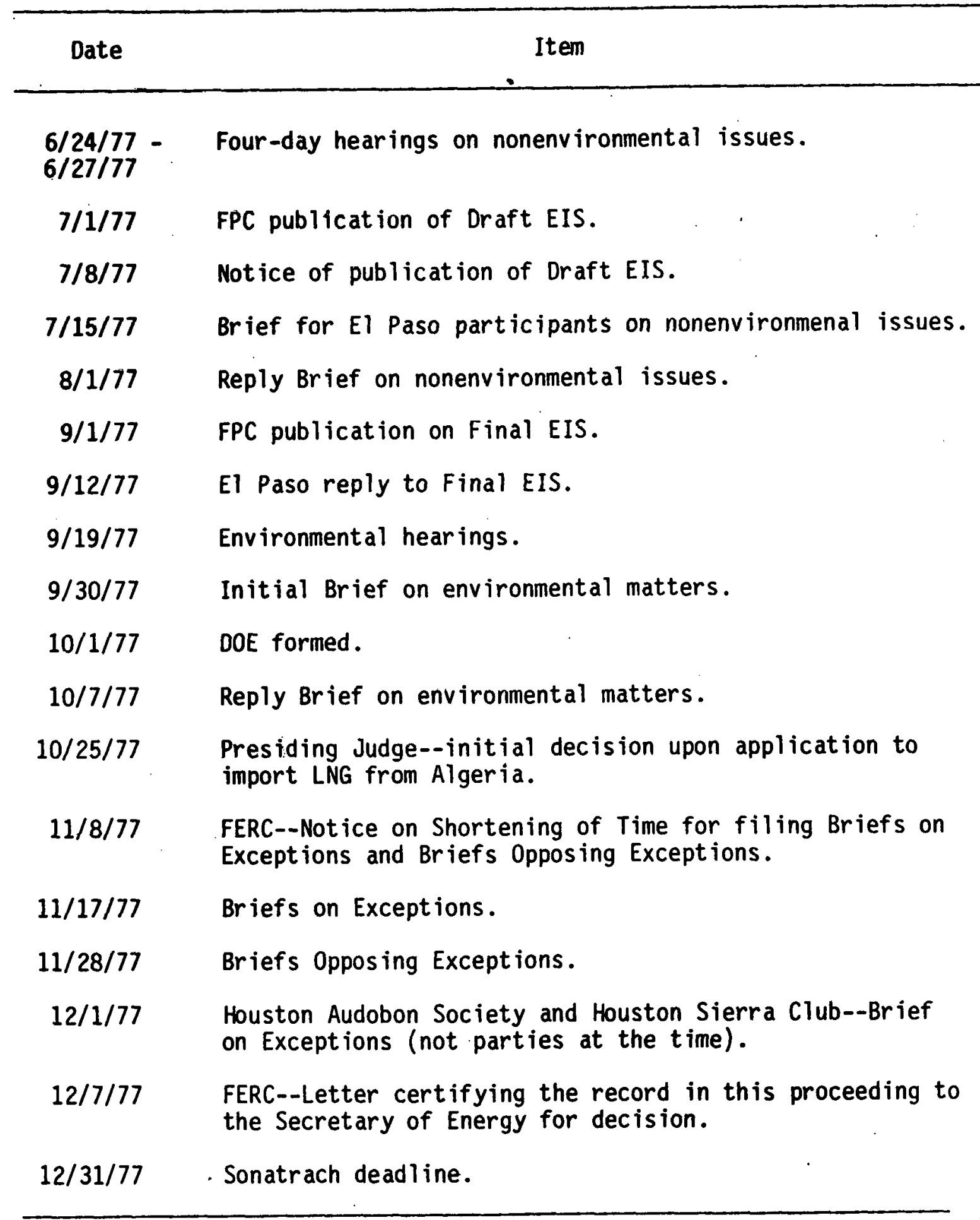


TABLE. 2-6. CONCLUDED

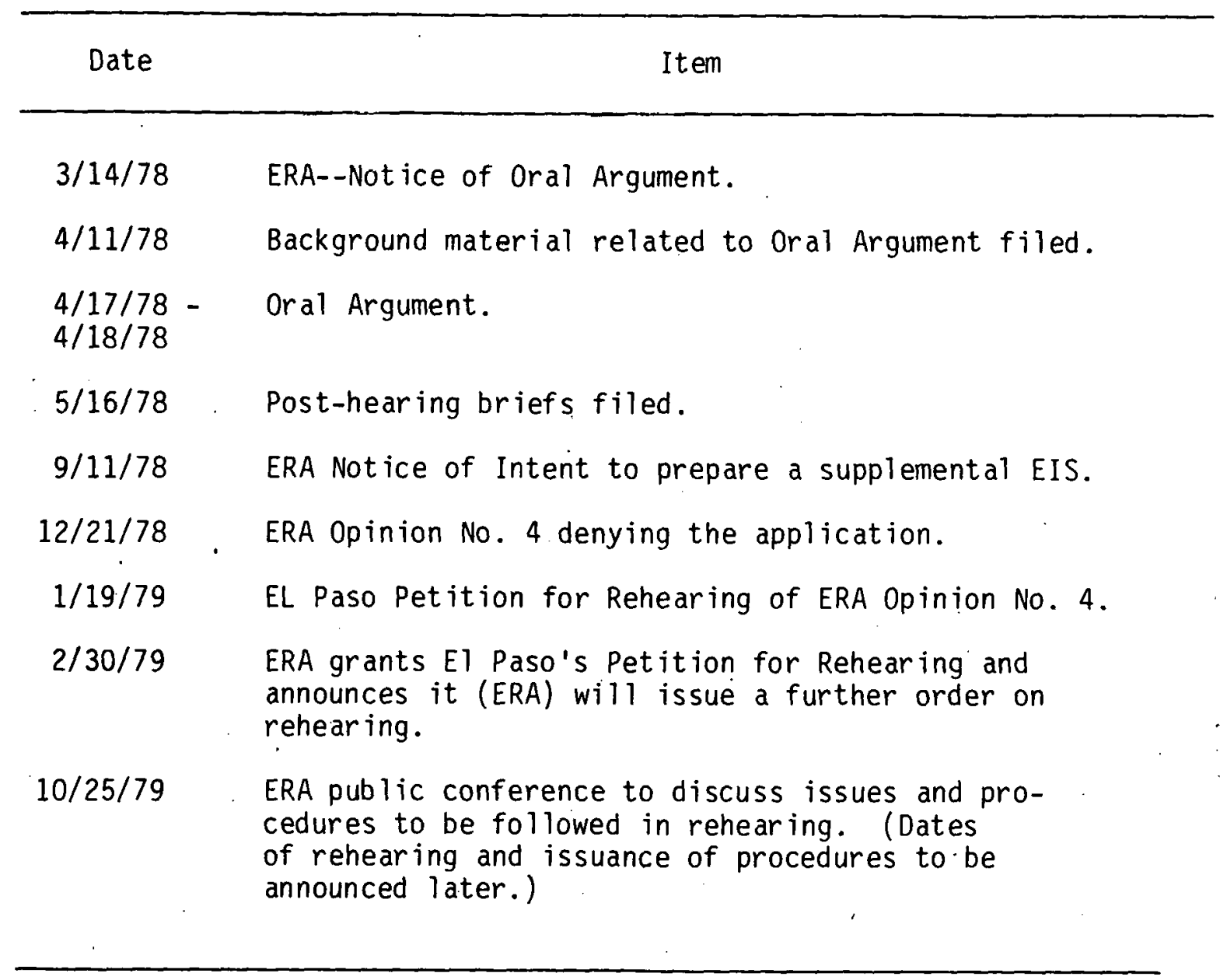


TABLE 2-7. ORGANIZATIONAL STRUCTURE OF THE WESTERN LNG PROJECT

\begin{tabular}{|c|c|c|}
\hline Function & Project Corporation & Parent Corporation \\
\hline $\begin{array}{l}\text { Exploration and development } \\
\text { in Indonesia }\end{array}$ & Mobil 0il Indonesian, Inc. & Mobil \\
\hline $\begin{array}{l}\text { Liquefaction of Indonesian } \\
\text { gas }\end{array}$ & $\begin{array}{l}\text { Pertamina (assisted by } \\
\text { Mobil) }\end{array}$ & Indonesian government \\
\hline Transportation from Indonesia & $\begin{array}{l}\text { Pacific Indonesia LNG } \\
\text { Company (PacIndonesia)a }\end{array}$ & $\begin{array}{l}\text { Pacific Lighting Corporation } \\
\text { (50\% of funding provided by } \\
\text { PG\&E) }\end{array}$ \\
\hline $\begin{array}{l}\text { Collection and liquefaction } \\
\text { of Alaskan natural gas }\end{array}$ & $\begin{array}{l}\text { Pacific Alaska LNG Company } \\
\text { (Pacific Alaska) }\end{array}$ & Pacific Lighting Corporation \\
\hline $\begin{array}{l}\text { Cosponsor for collection and } \\
\text { liquefaction }\end{array}$ & $\begin{array}{l}\text { Alaska California LNG } \\
\text { Company }\end{array}$ & PG\&E \\
\hline $\begin{array}{l}\text { Partnership of Pacific Alaska } \\
\text { and Alaska California }\end{array}$ & $\begin{array}{l}\text { Pacific Alaska LNG } \\
\text { Association. }\end{array}$ & $\begin{array}{l}\text { Pacific Lighting Corporation } \\
\text { and PG\&E }\end{array}$ \\
\hline $\begin{array}{l}\text { Transportation of Alaskan } \\
\text { gas }\end{array}$ & $\begin{array}{l}\text { Pacific Lighting Marine } \\
\text { Association }\end{array}$ & Pacific Lighting Corporation \\
\hline $\begin{array}{l}\text { Terminal operations (service } \\
\text { to PacIndonesia and Pacific } \\
\text { Alaska--no transfer of title } \\
\text { to LNG) }\end{array}$ & $\begin{array}{l}\text { Western LNG Terminal } \\
\text { Associates } \\
:\end{array}$ & $\begin{array}{l}\text { Partnership formed } \\
\text { by Pacific Lighting } \\
\text { Corporation and PG\&E }\end{array}$ \\
\hline
\end{tabular}

${ }^{a_{F}}$ ive shipping companies will produce nine ships dedicated to transporting LNG from Indonesia to the Western LNG terminal. 
for interstate commerce (transfer of gas from Alaska to California).

- obtaining a permit (under California Law [SB 1081] Erom the (PUC) to construct and operate an LNG terminal.

A permit for construction is also required from the COE; however, this is not considered to be a critical schedule path.

- The permitting process was compounded by differences between the state and federal governments regarding siting. The original project application was for three different sites-Los Angeles, oxnard, and Point Conception. The Point Conception site was to receive gas by ship from Alaska's North Slope through the El Paso Alaska Company. The Los Angeles Harbor site was to receive gas by ship from south Alaska's Cook Inlet area through Pacific Alaska. LNG. The oxnard site was to receive gas by ship from the Republic of Indonesia through the Pacific Indonesia LNG Company. In July, 1977, Administrative Law Judge Gordon of the Federal Power Commission approved the Pacific Indonesia project for the oxnard site with conditions relative to project financing. Two months later, the Governor of California signed into law the LNG Terminal Act of 1977, effectively denying a terminal at the Los Angeles or oxnard sites on the basis of population densities near the site. " shortly thereafter, the Federal Energy Act was signed into law, and the Federal Power Commision's responsibilities were divided between the ERA and the FERC as described elsewhere in this section. On '30 December 1977, the ERA issued Opinion Number one approving

*The law specifies a maximum density of 10 persons per square mile within a distance of one mile of the perimeter of the site, and 60 persons per square mile within four miles. These limits also apply to marine tanker vessel traffic. 
the project with certain conditions. The conditions included (1) development of an "interruption contingency plan," (2) revision of the pricing formula (cost-of-service tariff and escalator clause), and (3) conformance with municipal requirements if oxnard were chosen as the site. Condition (3) supported the city of oxnard's requirement that storage tanks be placed underground and that vessel-to-storage transfer lines be placed underwater. Another safety-related condition was the requirement for a Final Safety Analysis Report to be submitted and approved prior to the commencement of operations at the California LNG terminal as proposed at the hearing in Los Angeles. While the Administrative Law Judge did not. accept the requirement for the Final Safety Analysis Report, the ERA chose to impose it as a condition.

With respect to the siting issue, Opinion Number one conditionally approved oxnard, but specifically stated that alternative sites were not rejected, nor were the applicants precluded from requesting alternative sites. It further stated that ". - California should have an opportunity to decide whether or not the operation of an LNG facility at oxnard is acceptable.. ." while at the same time reserving the right to ". . . reconsider... whether federal jurisdiction should be exercised exclusively . . . ." As the opinion stands, however, compliance with California's LNG Act of 1977 is a prerequisite to the DOE/ERA approval.

Opinion Number Six, dated 24 April 1979, raised the siting issue again, asking for comments by other agencies and intervenors by 15 June 1979 and allowing until 13 July for rebuttal. In this opinion the ERA also noted that it would withhold its final decision on underground tanks and underwater transfer piping for the oxnard site until the basic siting issue was resolved. It also elaborated on the requirement for a safety review, renaming it the Design and Construction Safety Review 
in an effort to clarify the point that the review was not intended to precipitate further adjudicary hearings or twostage certification.

The issue of siting is normally addressed under section 7 of the National Gas Act and would ordinarily fall under the FERC's jurisdiction rather than the ERA's. For the PacIndonesia project, which is to import gas and falls under Section 3 of the Natural Gas Act, the FERC does not have jurisdiction as no interstate transfers are involved. The ERA, in this case, is including section 7 requirements in its evaluation on the basis that an FPC Administrative Law Judge had previously found that the FPC could include such requirements as conditions to its approval under section 3 . When the ERA was delegated responsibility for section 3 by the secretary of Energy, it also assumed responsibility for the section 7 type of evaluation for the PacIndonesia Project.

Western LNG Terminal, however, will regasify LNG not only from Indonesia but also from Alaska. Thus, the terminal will be involved in interstate transfers and will fall under the jurisdiction of the FERC.

Eariy in 1978, acting under California's LNG Terminal Act of 1977, the California Coastal Commission identified for future study five candidate sites for the Western LNG Terminal: Point Conception, Guadalupe Dunes, Camp Pendleton, Tajiguas, and oxnard. oxnard was included in order to "provide a more complete evaluation of environmental alternatives" (Ref 2-16). The selected sites were chosen from a larger sample of 50 identified in a preliminary search. From the five candidates, the California Public Utilities Commission (CPUC) chose point Conception in a decision issued on $31 \mathrm{July}$ 1978. At the same time the CPUC approved the Final EIS in July 1978, and granted a conditional permit for that site. 
In October 1978, the FERC staff published its Final EIs, again recommending the oxnard site for the project. That recommendation was preceded by a screening of 72 possible locations from which four potentially acceptable sites were selected--Rattlesnake Canyon, Naples, oxnard, and Dos Pueblos Ranch at Los Varas. The FERC staff's elimination of the Point Conception site was most strongly influenced by seismic (earthquake) considerations. The conclusion stated, however, that the.FERC staff would regard Point Conception with disfavor on other grounds (e.g., cost of facility construction) even if the seismic issue could be dismissed.

The FERC staff's unfavorable view on the Point Conception site and California's position on the oxnard site are both based at least in part on safety issues. The FERC notes that the facility should not be located near a seismic fault when other options are available. Its position is rooted in the issue of the probability of an accident. The california position is based on the number of people near the site, or the potential consequence of an accident. * Also, the FERC's position implies a primary concern for plant safety, whereas California's position implies a primary concern for public safety.

The COE chose not to act on the application for the construction permit until the siting issue was settled, on the basis that it did not wish to invest time and effort needlessly in case the applications to the DOE were denied.

\footnotetext{
*At this point in the history of the Western LNG Project, this distinction is, of course, strictly philosophical. The California position is now strengthened by its conformance with the state's legislation on LNG siting, and the FERC staff's position, which antedates California's law on LNG siting, has been consistent for at least three years. Nonetheless, this example highlights the potential problem that can arise in making LNG siting decisions when federal and state approvals are required.
} 
The FERC Administrative Law Judge issued his initial decision approving Point Conception on 13 August 1979. On 27 September 1979, the DOE (ERA) gave its final approval for the Point Conception Terminal, in effect supporting the CPUC position. Shortly thereafter, on 12 october 1979, the Administrative Law Judge issued the final order approving the project. Legal appeals to his decision have been filed by a number of project opponents in the Federal District Court. Site construction will depend upon the outcome of these appeals.

The complete chronology for the project is listed in Table 2-8.

b. Peakshaving facilities (Ref. 2-17)--The Institute of Gas Technology has noted that peakshaving is necessary for two reasons: (1) to meet demand fluctuations, and (2) to hedge supply curtailments. At present, 79 percent of the peakshaving requirement is met by underground storage of nàtural gas, 13 percent by LNG, and 7 percent by propane/air. There are 63 peakshaving plants in the United states, with a total storage capacity of about 65 billion scf. Their liquefaction capacity is $350 \mathrm{million}$ scf/day, and their vaporization capacity is 8 billion scf/day. There are also 55 satellite peakshaving facilities having a total storage* capacity of 8 billion scf and vaporization capacity of 1 billion scf/day. The satellite facilities have no liquefaction capabilities. These facilities figured prominently in meeting the high demands of the 1976-77 and 1977-78 winters, and probably prevented some curtailments. Existing and planned peakshaving and satellite facilities in the U.S. are summarized in Tables 2-9, 2-10, and 2-11.

Peakshaving facilities are subject to the same federal laws as other LNG facilities; however, they are for the most 
TABLE 2-8. CHRONOLOGY OF EVENTS--THE WESTERN LNG PROJECT

Date

Item

9/6/73 Contract signed with Pertamina for purchase of LNG.

11/30/73 PacIndonesia FPC application filed (Section 3, CP 74-160).

2/15/74 PacIndonesia FPC application filed (Section 7 (c), CP 74-207).

9/17/74 Terminal Company FPC application filed (CP 75-83)

for LNG terminal facilities at Los Angeles, Oxnard.

and Point Conception (Little Cojo Bay).

1/9/75 PacIndonesia and Pertamina agree to LNG pricing formula changes and to increase in base price from 630 to $\$ 1.25$ per million Btu.

2/26/75 Western LNG Terminal Associates (WLNG) entered contract with Pacific Alaska LNG Company for gas from Cook Inlet.

3/11/75 WLNG entered into a contract with PacIndonesia.

3/18/75 LNG sale contract approved by the -Indonesia government.

3/31/75 PacIndonesia and Terminal Company FPC amendments filed to reflect LNG purchase contract changes and changes in receiving facility concept, ownership and location (CP 74-160, CP 74-207, CP 75-83). CP 75-83 included application for three terminal sites--Terminal Island (South Alaska gas), Oxnard (Indonesia gas), and Point Conception' (EI Paso Prudhoe Bay gas).

9/17/75 Application's for Section 7 permits for terminals at Los Angeles Harbor, Oxnard; and Point Conception filed by Western Terminal with FPC.

10/29/75 Agreements signed with three foreign shipping companies to lease three LNG ships for twenty years.

11/?/75 FPC circulated Final EIS for terminal at Point Conception, recommending construction of terminal at 0xnard instead. 
TABLE 2-8. CONTINUED

Date

Item

11/19/75 Agreements signed with two U.S. shipping companies to lease six ships for 20 years.

12/3/75 FPC order issued to set the proceedings for the project.

12/10/75 Direct case filing completed before FPC. (Direct testimony and exhibits.)

12/16/75 Hearings began before the FPC.

1/27/76 Memorandum of understanding signed with Pacific Gas and Electric Company to share equally in all past and ongoing costs and resultant gas supplies of the project.

8/3/76 Draft EIR on Oxnard terminal released for review by City of Oxnard (SES Study).

11/18/76 Continued public hearing before Planning Commission. Public hearing for adoption of EIR by Planning Commission set for April 1977.

12/30/76. FPC staff issued Final EIS.

2/25/77 PacIndonesia hearings before the FPC concluded.

7/22/77 FPC Administrative Law Judge Gordon issued initial decision approving project with Oxnard terminal site, but with conditions relative to ship and terminal financing.

8/22/77 Exceptions filed to initial decision of $7 / 22$.

9/16/77 The LNG Terminal Act of 1977, signed into law by Governor Brown. (El iminates Oxnard from immediate consideration--see LNG Terminal Project.)

10/1/77 ERA delegated authority in newly created DOE to issue final order on project.

10/14/77 WLNG filed Application No. 57626 with CPUC for permit to construct and operate terminal at Point Conception.

10/22/77 Oral agreement on importation of gas from Indonesia held in Los Angeles. 
TABLE 2-8. CONTINUEd

Date

Item

11/11/77 Application to ERA (Docket No. 77-001-LNG) amended for single terminal at Point Conception.

11/15/77 Application to FERC (Docket No. CP75-83) amended for single terminal at Point Conception.

12/30/77 ERA conditionally approved project for 0xnard without malice toward other sites.

1/9/78 PG\&E and Pacific Lighting Corp. filed Application. No. 59772 with CPUC for Certificate of Public Convenience and Necessity for pipeline to Kern County.

1/30/78 Filed with ERA for a rehearing on ERA rejection of - escalation clause in Pertamina contract, no provision for flow through of any increase in shipping. costs and absence of procedure to al low concurrent federal/state decisions on LNG terminal siting.

2/1/78 California Coastal Commission identified five sites for LNG terminals, including Point Concept ion.

2/28/78 ERA ordered rehearing on Opinion Number One.

2/28/78 CPUC published Draft EIR.

4/28/78 Application for construction permit filed with Los Angeles District, COE.

5/10/78 Jurisdiction for PacIndonesia terminal siting transferred from ERA to FERC and this phase to be consolidated with PacAlaska project hearings.

6/20/78 Consolidated hearings began before FERC.

$7 / 28 / 78 \quad$ CPUC publishes Final EIR.

7/28/78 Filed with ERA revised escalation provision in Pertamina contract to cover future LNG price adjustments. 
TABLE 2-8. CONTINUED

Date Item

7/31/78 CPUC issued favorable decision; with conditions, on permit application for Little Cojo Bay terminal at Point Conception.

9/20/78 Motion filed with ERA and FERC requesting expeditious. procedures so that a federal decision on terminal siting can be made by $12 / 31 / 78$.

9/29/78 ERA approved revised escalation provision in Pertamina contract.

10/31/78 Final EIS issued by FERC staff.

12/4/78 Southern California LNG Terminal Company (SCLNG) filed application with FERC-for an LNG terminal at Dee Canyon.

1/18/79 FERC hearings completed.

1/18/79 SCLNG filed motion with FERC to consolidate its application with the WLNG application.

4/5/79 FERC denied SCLNG motion to consolidate proceedings with WLNG and ordered a revised briefing schedule.

4/24/79 ERA issued Opinion Number Six on treatment of shipping and other costs, siting and safety.

5/11/79 Initial briefs filed on certain issues.

5/31/79 Reply briefs filed.

6/5/79 CPUC establishes safety regulations for construction and operation of the terminal.

6/7/79 Petition filed with CPUC for final permit for construction and operation of terminal.

6/14/79 California Supreme Court denies petitions to review the CPUC's, 7/31/78 decision conditionally approving the Little Cojo Bay terminal site.

6/15/79 FERC denies request to rehear the issue of California's gas supply and demand situation. 
TABLE 2-8. “ CONCLUDED

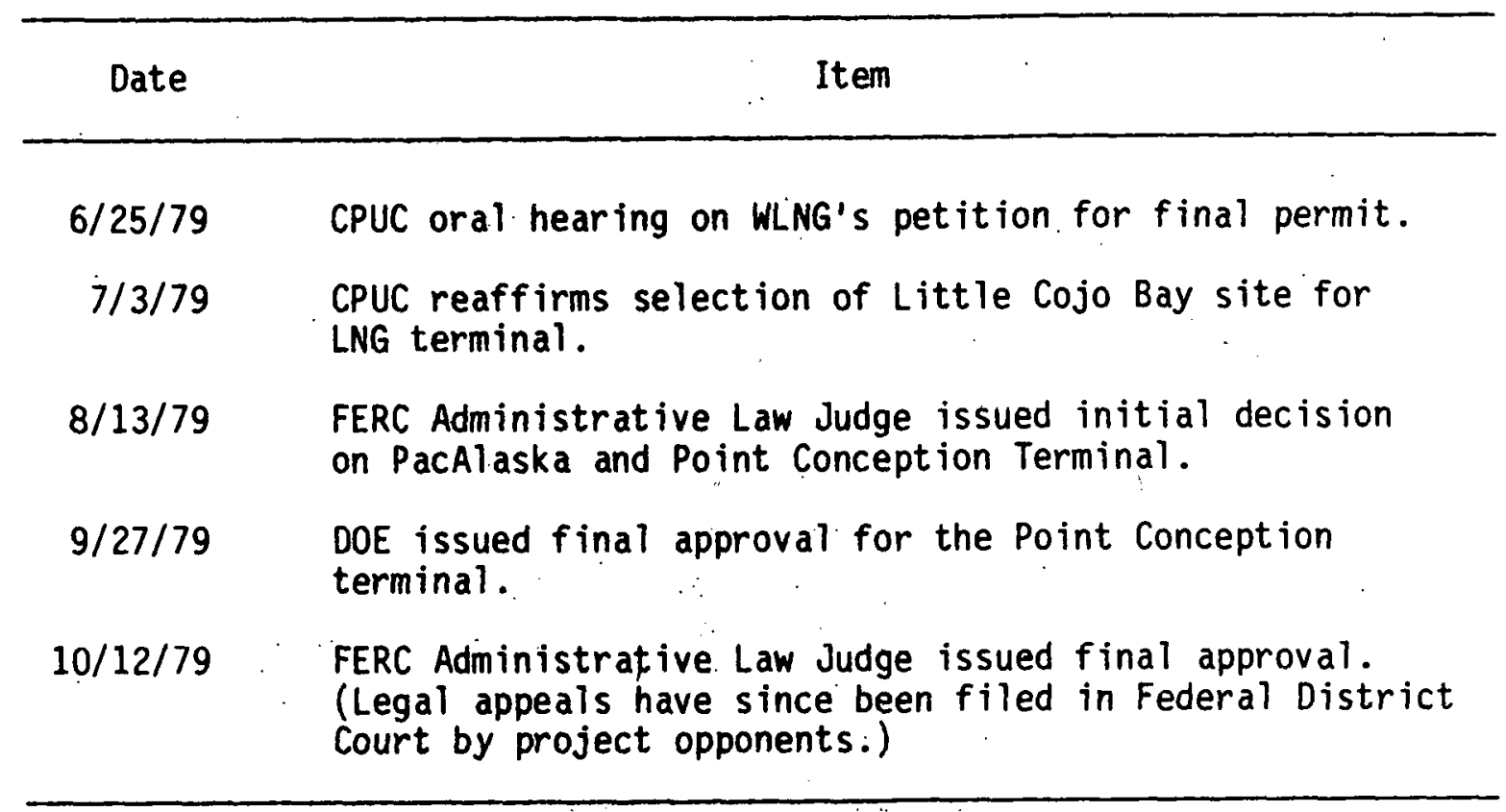


TABLE 2-9. LNG PEAKSHAVING PLANT FACILITIES--

U.S. AND CANADA

\begin{tabular}{|c|c|c|c|}
\hline Company and plant site & $\begin{array}{l}\text { Liquefaction } \\
\text { capacity } \\
\left(10^{6} \text { scf } / \text { day }\right)^{\star}\end{array}$ & $\begin{array}{l}\text { Stor age } \\
\left(10^{6} \text { scf }\right)\end{array}$ & $\begin{array}{l}\text { Design/total } \\
\text { vaporization } \\
\left(10^{6} \text { scf/day }\right)\end{array}$ \\
\hline $\begin{array}{c}\text { Alabama Gas Corporation } \\
\text { Birmingham, Alabama }\end{array}$ & 3.9 & 620 & $36 / 108$ \\
\hline (second tank) & $\cdots$ & 620 & 48 \\
\hline $\begin{array}{l}\text { Alabama Gas Corporation } \\
\text { Coosada, Alabama }\end{array}$ & 2.7 & 620. & $40 / 80$ \\
\hline $\begin{array}{l}\text { Arkansas-Missouri Power Company } \\
\text { Yarbro, Arkansas }\end{array}$ & 0.7 & 191. & $30 / 60$ \\
\hline $\begin{array}{l}\text { At lanta Gas/Light Company } \\
\text { Riverdale, Georgia }\end{array}$ & - 10.0 & $\begin{array}{c}1000 \\
\because \cdots\end{array}$ & 200 \\
\hline (second tank) & - & 1500 & -- \\
\hline $\begin{array}{l}\text { Balt imore Gas and Electric Co. } \\
\text { Balt imore, Maryland }\end{array}$ & 2.75 & 500 & $125 / 187.5$ \\
\hline (Plant No. 2) & 2.4 & 500 & 62.5 \\
\hline $\begin{array}{l}\text { Bay State Gas Company } \\
\text { Ludlow, Massachusetts }\end{array}$ & 7.5 & 1000 & 55 \\
\hline $\begin{array}{l}\text { Boston Gas Company } \\
\text { Dorchester, Massachusetts }\end{array}$ & 6.0 & 1000 & 187.5 \\
\hline (second tank) & -- & 1150 & --- \\
\hline $\begin{array}{l}\text { Boston Gas Company } \\
\text { Lynn, Massachusetts }\end{array}$ & 7.35 & 1000 & 86.4 \\
\hline $\begin{array}{l}\text { British Columbia Hydro } \\
\text { and Power Authority } \\
\text { Delta, B.C. }\end{array}$ & 2.50 & 625 & 150 \\
\hline $\begin{array}{l}\text { Brooklyn Union Gas Company } \\
\text { Brooklyn, New York }\end{array}$ & 5.7 & 600 & 160 \\
\hline (second tank) & -- & 1000 & --- \\
\hline $\begin{array}{l}\text { Chattanooga Gas Company } \\
\text { Chattanooga, Tennessee }\end{array}$ & 10.0 & 1200 & $60 / 90$ \\
\hline
\end{tabular}

${ }^{*}$ scf $=$ standard cubic foot 
TABLE 2-9. CONTINUED

\begin{tabular}{|c|c|c|c|}
\hline Company and plant site & $\begin{array}{c}\text { Liquefaction } \\
\text { capacity } \\
\left(10^{6} \text { scf/day }\right)\end{array}$ & $\begin{array}{l}\text { Storage } \\
\left(10^{6} \text { scf }\right)\end{array}$ & $\begin{array}{l}\text { Design/total } \\
\text { vaporization } \\
\left(10^{6} \text { scf/day }\right)\end{array}$ \\
\hline $\begin{array}{l}\text { Citizens Gas and Coke Utility } \\
\text { Beech Grove, Indiana }\end{array}$ & 5.0 & 1000 & 180 \\
\hline $\begin{array}{l}\text { Commonwealth Natural Gas Corp. } \\
\text { Tidewater, Virginia }\end{array}$ & 5.0 & 1200 & 105 \\
\hline $\begin{array}{l}\text { Connect icut Natural Gas Corp. } \\
\text { Rocky Hill, Connecticut }\end{array}$ & 6.0 & 1200 & 80 \\
\hline $\begin{array}{l}\text { Consolidated Edison of New York } \\
\text { Astoria, New York }\end{array}$ & 5.4 & 1000 & $240 / 300$ \\
\hline $\begin{array}{l}\text { Delmarva Power and Light Company } \\
\text { Wilmington, Delaware }\end{array}$ & 1.5 & 250 & 50 \\
\hline $\begin{array}{l}\text { East Tennessee Natural Gas Co. } \\
\text { Fordtown, Tennessee }\end{array}$ & 5.5 & 1200 & 105 \\
\hline $\begin{array}{l}\text { Fall River Gas Company } \\
\text { Fall River, Massachusetts }\end{array}$ & 0.5 & 157 & 20 \\
\hline $\begin{array}{l}\text { Gas Metopolitan, Inc. } \\
\text { Montreal, Quebec, Canada }\end{array}$ & 10.0 & 1000 & 240 \\
\hline (second tank) & --- & 1000 & -- \\
\hline $\begin{array}{l}\text { Gas Light Company of Columbus } \\
\text { Columbus, Georgia }\end{array}$ & 2.0 & 500 & $30 / 60$ \\
\hline $\begin{array}{l}\text { Intermountain Gas Company } \\
\text { Boise, Idaho }\end{array}$ & 3.7 & 600 & $60 / 90$ \\
\hline $\begin{array}{l}\text { Iowa-Illinois Gas and } \\
\text { Electic Co. } \\
\text { Bettendorf, Iowa }\end{array}$ & 2.0 & 500 & 50 \\
\hline $\begin{array}{l}\text { Iowa Power and Light Company } \\
\text { Des Moines, Iowa }\end{array}$ & 2.0 & 400 & 30 \\
\hline $\begin{array}{l}\text { Iowa Public Service Company } \\
\text { Waterloo, Iowa }\end{array}$ & 2.5 & 407 & 30 \\
\hline$(\text { second } \tan k)^{a}$ & $\cdots$ & 407 & -- \\
\hline
\end{tabular}

${ }^{a}$ Under construction. 
TABLE 2-9. CONTINUED

\begin{tabular}{|c|c|c|c|}
\hline Company and plant site & $\begin{array}{l}\text { Liquefaction } \\
\text { capacity } \\
\left(10^{6} \mathrm{scf} / \text { day }\right)\end{array}$ & $\begin{array}{l}\text { Storage } \\
\left(10^{6} \mathrm{scf}\right)\end{array}$ & $\begin{array}{l}\text { Design/total } \\
\text { vaporization } \\
\left(10^{6} \mathrm{scf} / \text { day }\right)\end{array}$ \\
\hline $\begin{array}{l}\text { Kokomo Gas and Fuel, Inc. } \\
\text { Kokomo, Indiana }\end{array}$ & 1.3 & 400 & 30 \\
\hline (second liquefaction unit) & 1.25 & $\cdots$ & -- \\
\hline $\begin{array}{l}\text { Long Is land Light ing Company } \\
\text { Holbrook, L.I., New York }\end{array}$ & 3.0 & 600 & 150 \\
\hline $\begin{array}{l}\text { Lowel1 Gas Company } \\
\text { Lowe } 11 \text {, Massachusetts }\end{array}$ & 4.5 & 1006 & 70 \\
\hline $\begin{array}{l}\text { Memphis Light, Gas and } \\
\text { Water Division } \\
\text { Memphis, Tennessee }\end{array}$ & 5.0 & 1000 & 201 \\
\hline $\begin{array}{l}\text { Metro Utilities District } \\
\text { Omaha, Nebraska }\end{array}$ & 6.0 & 1000 & 60 \\
\hline $\begin{array}{l}\text { Minnesota Gas Company } \\
\text { Burnsville, Minnesota }\end{array}$ & 5.0 & 1000 & 72 \\
\hline $\begin{array}{l}\text { NEGEA-Air Products and } \\
\text { Chemicals, Inc. } \\
\text { Hopkinton, Massachusetts }\end{array}$ & 18.5 & 2000 & 248 \\
\hline (third $\operatorname{tank})$ & --- & 2000 & $\cdots$ \\
\hline $\begin{array}{l}\text { Northern and Central Gas Co. } \\
\text { Hager, Ontario, Canada }\end{array}$ & 2.5 & 625 & 85 \\
\hline $\begin{array}{l}\text { Northern Indiana } \\
\text { Public Service } \\
\text { La Porte, Indiana }\end{array}$ & 10.0 & 2000 & 300 \\
\hline $\begin{array}{l}\text { Northern Indianab } \\
\text { Public Service } \\
\text { La Porte, Indiana }\end{array}$ & 10.0 & 2000 & 300 \\
\hline $\begin{array}{l}\text { Northern Natural Gas Co.c } \\
\text { Wrenshall, Minnesota }\end{array}$ & 10.0 & 2128 & 200 \\
\hline
\end{tabular}


TABLE 2-9. CONTINUED

\begin{tabular}{|c|c|c|c|}
\hline Company and plant site & $\begin{array}{l}\text { Liquefaction } \\
\text { capacity } \\
\left(10^{6} \mathrm{scf} / \text { day }\right)\end{array}$ & $\begin{array}{l}\text { Storage } \\
\left(10^{6} \text { scf }\right)\end{array}$ & $\begin{array}{l}\text { Design/total } \\
\text { vaporization } \\
\left(10^{6} \mathrm{scf} / \text { day }\right)\end{array}$ \\
\hline $\begin{array}{l}\text { Northern States Power Company } \\
\text { Eau Claire, Wiscons in }\end{array}$ & 2.0 & 270 & 12 \\
\hline $\begin{array}{l}\text { Northwest Natural Gas Company } \\
\text { Portland, Oregon }\end{array}$ & 2.0 & 600 & $80 / 120$ \\
\hline $\begin{array}{l}\text { Northwest Natural Gas Company } \\
\text { Newport, Oregon }\end{array}$ & 5.5 & 1000 & 100 \\
\hline $\begin{array}{l}\text { Northwest Pipeline Corporation } \\
\text { P.lymouth, Washington }\end{array}$ & 6.0 & 1200 & 225 \\
\hline (second plant)c & $6: 0$ & 1200 & 75 \\
\hline $\begin{array}{l}\text { Peoples Gas, Light, and } \\
\text { Coke Company } \\
\text { Fisher, Illinois }\end{array}$ & 10.0 & 2000 & $300 / 354$ \\
\hline $\begin{array}{l}\text { Peoples Natural Gas, Division } \\
\text { of Northern Gas Companyb } \\
\text { Ventura, Iowa }\end{array}$ & 14.5 & 2000 & 75 \\
\hline $\begin{array}{l}\text { Philadelphia Electric Company } \\
\text { West Conshohocken, Penn. }\end{array}$ & 6.0 & 1200 & $180 / 300$ \\
\hline $\begin{array}{l}\text { Philadelphia Gas Works } \\
\text { Philadelphia, Pennsylvania }\end{array}$ & $\begin{array}{l}23.0 \\
\cdots\end{array}$ & 4000 & 500 \\
\hline $\begin{array}{l}\text { Piedmont Natural Gas Company } \\
\text { Charlotte, North Carol ina... }\end{array}$ & 5.0 & 1000 & $100 / 150$ \\
\hline $\begin{array}{l}\text { Public Service Company } \\
\text { of North Carolina } \\
\text { Gastonia; North Carolina }\end{array}$ & 3.0 & 1000 & $\therefore 100$ \\
\hline $\begin{array}{l}\text { Roanoke Gas Company } \\
\text { Roanoke, Virginia }\end{array}$ & 1.3 & 200 & 20 \\
\hline \multicolumn{4}{|l|}{$\begin{array}{l}\text { San Diego Gas and Electric Co. } \\
\text { Chula Vista, California }\end{array}$} \\
\hline $\begin{array}{l}\text { (Plant No. 1) } \\
\text { (Plant No. 2) }\end{array}$ & $\begin{array}{l}2.0 \\
7.0\end{array}$ & $\begin{array}{r}625 \\
1200\end{array}$ & $\begin{array}{l}120 \\
180\end{array}$ \\
\hline
\end{tabular}


TABLE 2-9. CONCLUDED

\begin{tabular}{|c|c|c|c|}
\hline Company and plant site & $\begin{array}{l}\text { Liquefaction } \\
\text { capacity } \\
\left(10^{6} \mathrm{scf} / \text { day }\right)\end{array}$ & $\begin{array}{l}\text { Stor age } \\
\left(10^{6} \text { scf }\right)\end{array}$ & $\begin{array}{l}\text { Design/total } \\
\text { vaporization } \\
\left(10^{6} \mathrm{scf} / \text { day }\right)\end{array}$ \\
\hline $\begin{array}{l}\text { South Carolina LNG Company } \\
\text { Bushey Park, South Carolina }\end{array}$ & 6.0 & 1006 & 60 \\
\hline $\begin{array}{l}\text { Southern Connecticut Gas Company } \\
\text { Milford, Connecticut }\end{array}$ & 6.6 & 1200 & 60 \\
\hline $\begin{array}{l}\text { Tennessee Natural Gas Lines } \\
\text { Nashville, Tennessee }\end{array}$ & 5.0 & 1000 & $100 / 150$ \\
\hline $\begin{array}{l}\text { Texas Eastern Transmission Co.d } \\
\text { Staten Is land, New York }\end{array}$ & 7.65 & -- & $195 / 292$ \\
\hline $\begin{array}{l}\text { Transcontinental Gas Pipe } \\
\text { Line Corporation } \\
\text { Hackensack, New Jersey }\end{array}$ & 7.0 & 1000 & 400 \\
\hline $\begin{array}{l}\text { Transcontinental Gas Pipe } \\
\text { Line Corporation } \\
\text { Carlstadt, New Jersey } \\
\text { (second tank) }\end{array}$ & $\because$ & 1000 &.-- \\
\hline $\begin{array}{l}\text { UGI Corporation } \\
\text { Temple, Pennsylvania }\end{array}$ & 2.1 & 250 & 30 \\
\hline $\begin{array}{l}\text { Utilities Board } \\
\text { Trussville, Alabama }\end{array}$ & 5.0 & 400 & 20 \\
\hline $\begin{array}{l}\text { Wiscons in Natural Gas Company } \\
\text { Oak Creek, Wiscons in }\end{array}$ & 0.75 . & 250 & 50 \\
\hline
\end{tabular}

${ }^{d}$ Storage destroyed 1973--to be replaced. 
TABLE 2-10. LNG SATELLITE FACILITIES (LARGE CAPACITY--FIELD CONSTRUCTED)

\begin{tabular}{|c|c|c|c|c|c|c|}
\hline Company and plant location & LNG Source & $\left(10^{6}\right.$ scf $)$ & $\begin{array}{l}\text { e volume } \\
(1000 \mathrm{gal})\end{array}$ & $\begin{array}{l}\text { Sendou } \\
110^{6}\end{array}$ & $\begin{array}{l}\text { ut capac } \\
\text { scf/day }\end{array}$ & \\
\hline $\begin{array}{l}\text { Atl anta Gas Light Company } \\
\text { Macon, Georgia }\end{array}$ & Southern Energy & 1500 & 50 & & $150^{\circ}$ & \\
\hline $\begin{array}{l}\text { Austell Gas Department } \\
\text { Austel1, Georgia }\end{array}$ & American LNG Corporation & 80 & 23 & $\vdots$ & 20 & : \\
\hline $\begin{array}{l}\text { Bay State Gas Company } \\
\text { Easton, Massachusetts }\end{array}$ & Distrigas Corporation & 800 & 225 & & 35 & \\
\hline $\begin{array}{l}\text { Boston Gas Company } \\
\text { Salem, Massachusetts }\end{array}$ & Boston Gas Company & 1000 & 290 & & 30 & \\
\hline $\begin{array}{l}\text { Cape Cod Gas Company } \\
\text { South Yarmouth, Mass achusetts }\end{array}$ & Lowe II Gas Company & 174 & 50 & & 20 & \\
\hline $\begin{array}{l}\text { Chicago Bridge and Iron Company } \\
\text { Cordova, Al abama }\end{array}$ & Various & 45 & 12.5 & & 3.5 & \\
\hline $\begin{array}{l}\text { Elizabethtown Gas Company } \\
\text { Elizabeth, New Jersey }\end{array}$ & $\begin{array}{l}\text { Transco } \\
\text { Hackensack, New Jersey }\end{array}$ & 150 & .45 & & 30 & \\
\hline $\begin{array}{l}\text { Fort Hill Natural } \\
\text { Gas Authority }\end{array}$ & $\begin{array}{l}\text { American LNG } \\
\text { Corporation }\end{array}$ & 35 & 10 & & 12 & \\
\hline $\begin{array}{l}\text { Haverh ill Gas Company } \\
\text { Haverh ill, Massachusetts }\end{array}$ & Distrigas Corporation & 400 & 116 & & 24 & \\
\hline $\begin{array}{l}\text { Lynichburg Gas Company } \\
\text { Lynchburg, Virginia. }\end{array}$ & Various & 42 & 12 & . & 7.2 & . \\
\hline
\end{tabular}


TABLE 2-10. CONTINUED

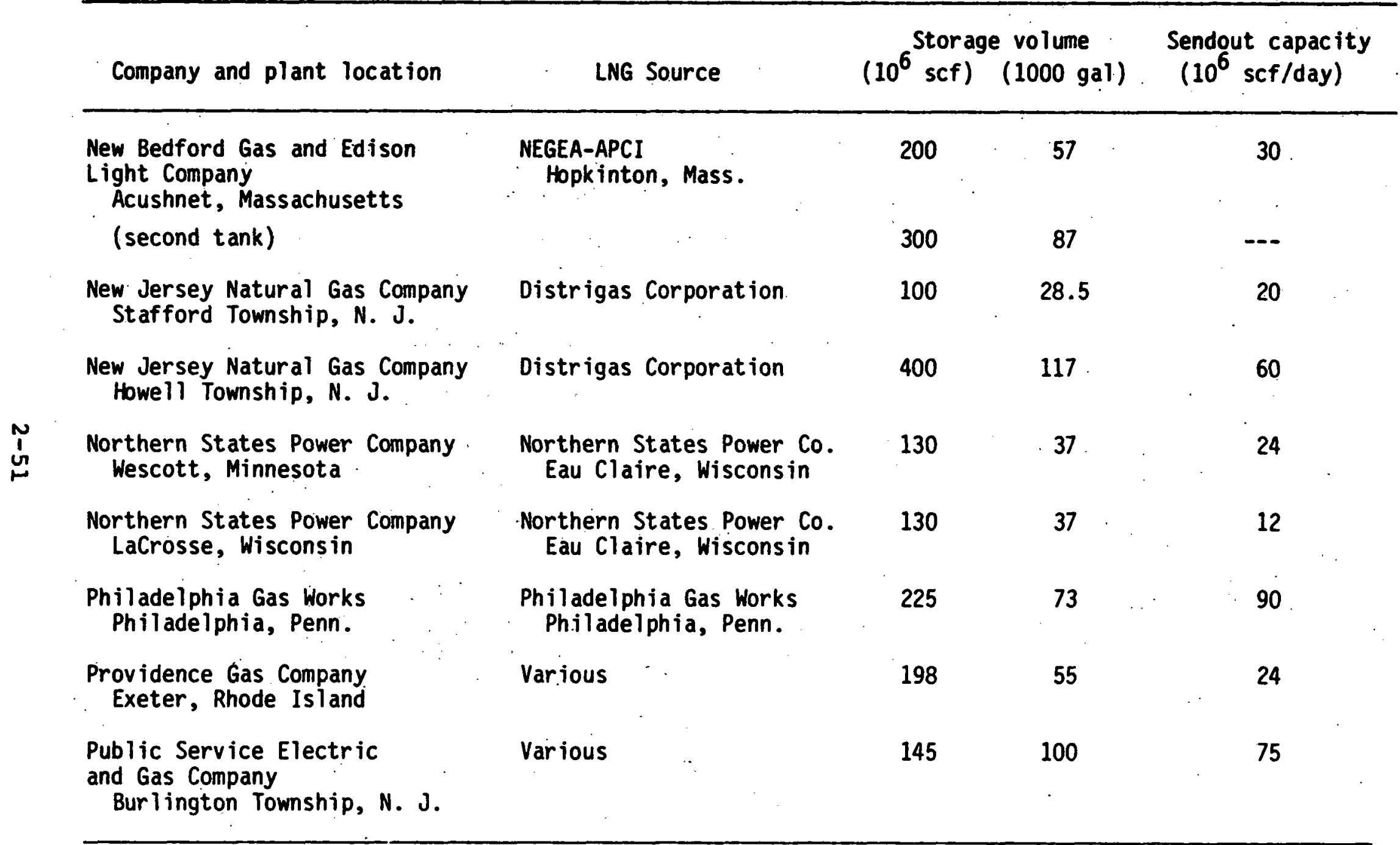


TABLE 2-10. CONCLUDED

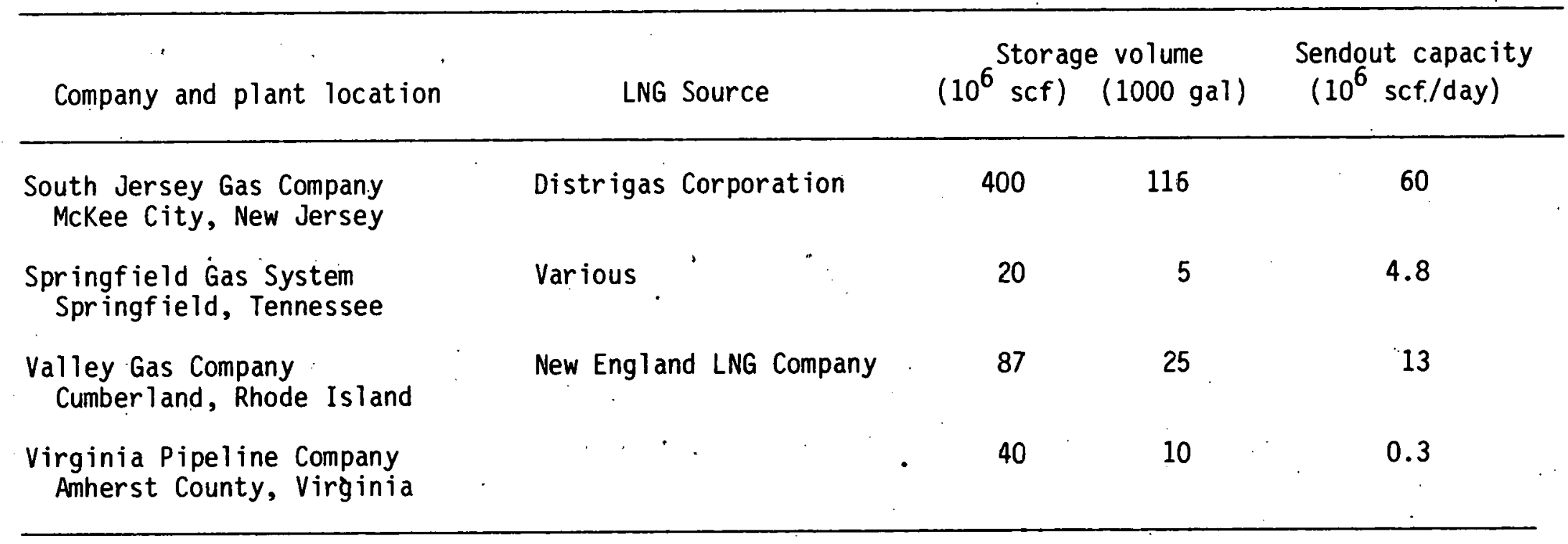

i

N

- . 
TABLE 2-11. LNG SATELLITE FACILITIES (SMÄLL CAPACITY-FIELD CONSTRUCTED)

\begin{tabular}{|c|c|c|c|c|}
\hline Company and plant location & LNG Source & $\left(10^{6}\right.$ scf $)$ & $\begin{array}{l}\text { e volume } \\
(1000 \mathrm{gal})\end{array}$ & $\begin{array}{l}\text { Sendout capacity } \\
\left(10^{6} \mathrm{scf} / \text { day }\right)\end{array}$ \\
\hline $\begin{array}{l}\text { Bay State Company } \\
\text { Marshfield, Massachusetts }\end{array}$ & $\begin{array}{l}\text { Lowell Gas Company } \\
\text { Tewksbury, Mass. }\end{array}$ & 9.0 & 110 & 12.5 \\
\hline $\begin{array}{l}\text { City of Brownsville } \\
\text { Gas Department }\end{array}$ & $\begin{array}{l}\text { Memphis Light, Gas and } \\
\text { Water Division }\end{array}$ & 0.5 & 6 & 10.0 \\
\hline $\begin{array}{l}\text { Cape Cod Gas Company } \\
\text { South Yarmouth, Massachusetts }\end{array}$ & $\begin{array}{l}\text { Lowe } 11 \text { Gas Company } \\
\text { Tewksbury, Mass. }\end{array}$ & 5.2 & 63.5 & 0.6 \\
\hline $\begin{array}{l}\text { Cape Cod Gas Company } \\
\text { Warcham, Massachusetts }\end{array}$ & $\begin{array}{l}\text { Lowell Gas Company } \\
\text { Tewksbury, Mass. }\end{array}$ & 4.5 & 55 & $\because 1.9$ \\
\hline $\begin{array}{l}\text { Concord Natural Gas Corporation } \\
\text { Concord, New Hampshire. }\end{array}$ & Bay State Gas Company & 4.5 & 55 & 4.8 \\
\hline $\begin{array}{l}\text { The Connecticut Light } \\
\text { and Power Company. } \\
\text { Danbury, Connecticut }\end{array}$ & $\begin{array}{l}\text { New England LNG Company } \\
\text { and Distrigas }\end{array}$ & 8.26 & 110 & 3.6 \\
\hline $\begin{array}{l}\text { The Connecticut Light } \\
\text { and Power Company } \\
\text { Norwalk, Connecticut }\end{array}$ & $\begin{array}{l}\text { New England LNG Company } \\
\text { and Distrigas }\end{array}$ & 4.5 & 55 & 2.4 \\
\hline $\begin{array}{l}\text { The Connecticut Light } \\
\text { and Power Company } \\
\text { Waterbury, Connecticut }\end{array}$ & $\begin{array}{l}\text { New England LNG Company } \\
\text { and Distrigas }\end{array}$ & 12.39 & 165 & 7.2 \\
\hline
\end{tabular}


TABLE 2-11. CONTINUED

\begin{tabular}{|c|c|c|c|c|}
\hline Company and plant location & LNG Source & $\left(10^{6}\right.$ scf $)$ & $\begin{array}{l}\text { (1000 gal) }\end{array}$ & $\begin{array}{l}\text { Sendout capacity } \\
\left(10^{6} \text { scf/day }\right)\end{array}$ \\
\hline $\begin{array}{l}\text { DeKalb-Cherokee Counties } \\
\text { Gas District } \\
\text { Fort Payne, Alabama }\end{array}$ & Chattanooga Gas Company & $4: 5$ & 22 & 2.2 \\
\hline $\begin{array}{l}\text { Elizabethtown Gas Company } \\
\text { Hackett.stown, New Jersey }\end{array}$ & $\begin{array}{l}\text { Transco } \\
\quad \text { Hackensack, N.J. }\end{array}$ & 1.7 & 21 & 5.8 \\
\hline $\begin{array}{l}\text { Fitchburg Gas and Electric } \\
\text { Light Company } \\
\text { Westminster, Massachusetts }\end{array}$ & $\begin{array}{l}\text { Lowe } 11 \text { Gas Company } \\
\text { Tewksbury, Mass. }\end{array}$ & 4.5 & 55 & 7.2 \\
\hline $\begin{array}{l}\text { Gas Service, Inc. } \\
\text { Nashua, New Hamphshire }\end{array}$ & New England LNG Company & 4.5 & 55 & 5.0 \\
\hline $\begin{array}{l}\text { The Hartford Electric } \\
\text { Light Company } \\
\text { Montville, Connecticut }\end{array}$ & New England LNG Company & 4.4 & 55 & 2.2 \\
\hline $\begin{array}{l}\text { The Hartford Electric } \\
\text { Light Company } \\
\text { St amford, Connecticut }\end{array}$ & New England LNG Company & 4.5 & 55 & 4.8 \\
\hline $\begin{array}{l}\text { The Hartford Electric } \\
\text { Light Company } \\
\text { Torrington, Connecticut }\end{array}$ & New England LNG Company & 4.2 & 55 & 3.0 \\
\hline $\begin{array}{l}\text { Holyoke Gas Department } \\
\text { Holyoke, Massachusetts }\end{array}$ & $\begin{array}{l}\text { Lowe l I Gas Company } \\
\text { Tewksbury, Mass. }\end{array}$ & 18.0 & 220 & 12.0 \\
\hline
\end{tabular}


TABLE 2-11. CONTINUED

\begin{tabular}{|c|c|c|c|c|}
\hline Company and plant location & LNG Source & $\left(10^{6}\right.$ Scf $)$ & $\begin{array}{l}\text { e volume } \\
(1000 \mathrm{gal})\end{array}$ & $\begin{array}{l}\text { Sendout capacity } \\
\left(10^{6} \mathrm{scf} / \text { day }\right)\end{array}$ \\
\hline $\begin{array}{l}\text { Lawrence Gas Company } \\
\text { Lawrence, Massachusetts }\end{array}$ & $\begin{array}{l}\text { Lowell Gas Company, } \\
\text { Tewk sbury, Mass. } \\
\text { Springfield Gas } \\
\text { Light Co. } \\
\text { Springfield, Mass. }\end{array}$ & 12.0 & 150 & 19.2 \\
\hline $\begin{array}{l}\text { Lowe } 11 \text { Gas Company } \\
\text { Wilmington, Massachusetts }\end{array}$ & $\begin{array}{l}\text { Lowell Gas Company } \\
\text { Tewksbury, Mass. }\end{array}$ & 2.5 & -30 & 12.0 \\
\hline $\begin{array}{l}\text { Lowe 11 Gas Company } \\
\text { Westford, Massachusetts }\end{array}$ & $\begin{array}{l}\text { Lowe } 11 \text { Gas Company } \\
\text { Tewksbury, Mass. }\end{array}$ & 5.0 & 55 & 6.0 \\
\hline $\begin{array}{l}\text { Manchester Gas Company } \\
\text { Manchester, New Hamphshire }\end{array}$ & New England LNG Company & 4.5 & 55 & 6.0 \\
\hline $\begin{array}{l}\text { Middleboro Gas and } \\
\text { Electric Department } \\
\text { Middleboro, Massachusetts }\end{array}$ & $\begin{array}{l}\text { Lowell Gas Company } \\
\text { Tewksbury, Mass. }\end{array}$ & 2.5 & 30 & 5.0 \\
\hline $\begin{array}{l}\text { Middle Tennessee Natural } \\
\text { Gas Authority } \\
\text { Smithville, Tennessee }\end{array}$ & $\begin{array}{c}\text { Memphis Light, Gas, } \\
\text { and Water Division } \\
\text { Memphis, Tennessee }\end{array}$ & 1.8 & 22 & 0.084 \\
\hline $\begin{array}{l}\text { Northern Utilities } \\
\text { Lewiston, Maine }\end{array}$ & New England LNG Company & 4.5 & 110 & 7.2 \\
\hline $\begin{array}{l}\text { City of Norwich Depart- } \\
\text { ment of Public Utilities } \\
\text { Norwich, Connecticut }\end{array}$ & New England LNG Company & 4.5 & 55 & 7.2 \\
\hline
\end{tabular}


TABLE 2-11. CONCLUDED

\begin{tabular}{|c|c|c|c|c|}
\hline Company and plant location & LNG Source & $\left(10^{6} \mathrm{scf}\right)$ & $\begin{array}{l}\text { e volume } \\
(1000 \mathrm{gal})\end{array}$ & $\begin{array}{l}\text { Sendout capacity } \\
\left(10^{6} \mathrm{scf} / \text { day }\right)\end{array}$ \\
\hline $\begin{array}{l}\text { Piedmont Natural Gas } \\
\text { Leno ir, North Carolina }\end{array}$ & American LNG Company & 4.1 & 55 & 2.2 \\
\hline $\begin{array}{l}\text { Savannah Public } \\
\text { Utility Department } \\
\text { Savannah, Tennessee }\end{array}$ & Chattanooga Gas Company & 0.85 & 11 & 1.5 \\
\hline $\begin{array}{l}\text { United Cities Gas Company } \\
\text { Murfreesboro, Tennessee }\end{array}$ & & 4.5 & 55 & 0.2 \\
\hline $\begin{array}{l}\text { UGI Corporation } \\
\text { Hazelton, Pennsylvania }\end{array}$ & UGI Corporation & 0.85 & 11.5 & 2.16 \\
\hline $\begin{array}{l}\text { Westfield Gas Department } \\
\text { Westfield, Massachusetts }\end{array}$ & $\begin{array}{l}\text { Lowe } 11 \text { Gas Company } \\
\text { Tewksbury, Mass. }\end{array}$ & 9.0 & 110 & 12.0 \\
\hline $\begin{array}{l}\text { Wiscons in Gas Company } \\
\text { Rice Lake, Wiscons in }\end{array}$ & Northern States Power & 16.72 & 200 & 7.2 \\
\hline $\begin{array}{l}\text { Wiscons in Gas Company } \\
\text { Black River Falls, Wiscons in }\end{array}$ & Northern States Power & 0.85 & 11.5 & 10.0 \\
\hline
\end{tabular}


part inland and they usually store domestic gas. As a consequence, an Import order from the ERA is not usually required, and neither the coast Guard nor the COE is involved in the approval process. For interstate transfers, the FERC must approve the project under section 7 of the National Gas Act; intrastate transfers are entirely within the jurisdiction of state and local governments.

\section{(1) Northwest Pipeline LNG II Project--On 9 september} 1975, the Northwest Pipeline Company, headquartered in Salt Lake City, Utah, applied to the FPC for a Certificate of Public Convenience and Necessity to construct a peakshaving facility at Plymouth, washington. This facility was to have essentially the same characteristics as an existing facility built in 1974 at the same location, and thus represented a doubling of existing capability. Each storage tank holds 348,000 barrels of liquid (equivalent to 1.2 billion scf of gas). The combined existing and new facilities can liquefy $6 \mathrm{million}$ scf/day, and their maximum sendout is $300 \mathrm{million}$ scf/day of gas.

The plant is remotely sited. Plymouth, the nearest settlement, is three miles distant and has a population of about 250 people. It is in an agricultural region, with other small communities farther away.

The tanks are above ground, constructed on the floor of a pit with a peripheral berm. The volume of the pit and berm exceeds that of the tank. Each tank also has a catchment area within the pit which has enough capacity for full flow for one hour from one 1.2-inch suction nozzle: Tank and facility construction generally exceeds the DOT-OPSR regulations.

The critical path for permits for this site was the Certificate of Public Convenience. The only local building permit required was the county building permit, which was 
obtained in a routine manner. Approximately fifty other licenses and permits pertaining to zoning, health, safety, etc., were also obtained in a routine manner. Evaluations by other federal government agencies and comments of intervenors were obtained by the FPC through the process of public notice and public hearing. Since the plant produces no industrial effluents and no significant air emissions, there were no environmental controversles over water or air issues. After the public hearings were opened, Northwest Pipeline was requested to provide additional data on construction and on safety factors, to which they responded within a few months. The time from Northwest's last response until the Certificate was issued was eleven months. The Certificate was conditional upon the FPC's approval of the construction drawings and inspection of the facility.

Two inspections were made. The first was an in-process inspection on 17 February 1978, in which interior construction was observed from inside the tank. The second and final inspection was made on 31 May 1979. An inspector from the Washington state Utility and Transportation Commission was informed of and participated in inspections of the facility along with inspectors from the FERC (which replaced the FPC): Upon approval, construction was completed, and the new facility came on-line in the fall of 1979.

The chronology of these events is summarized in Table 2-12. overall, the permitting process took about 17 months, and the construction and inspection process took two years more.

The critical path for obtaining all required permits for. this peakshaving facility was considerably shorter than for the LNG terminals that were reviewed--one and a half years compared to four to six years. This difference appears to be due primarily to the fact that fewer federal approvals were required for the peakshaving facility. In particular, 
TABLE 2-12. CHRONOLOGY OF EVENTS--

NORTHWEST PIPELINE LNG II

\begin{tabular}{|c|c|}
\hline$\dot{\text { Date }}$ & Item \\
\hline $9 / 29 / 75$ & $\begin{array}{l}\text { Application for Certificate of Public Convenience and } \\
\text { Necessity. }\end{array}$ \\
\hline $10 / 15 / 75$ & Notice published in Federal Register.' \\
\hline $10 / 17 / 75$ & Request by FPC for additional data. \\
\hline $11 / 6 / 75$ & Deadline for Intervenor's Response. \\
\hline $12 / 02 / 75$ & Data provided by Northwest. \\
\hline $1 / 30 / 76$ & Request by FPC for safety factor data. \\
\hline $3 / 1 / 76$ & Data provided by Northwest. \\
\hline $2 / 7 / 77$ & Certificate issued by FPC. \\
\hline $5 / 12 / 77$ & Construction started. \\
\hline $7 / 12 / 77$ & Drawings submitted to FPC. \\
\hline $8 / 16 / 77$ & Tank design and construction plans approved. \\
\hline $2 / 17 / 78$ & In-process inspection. \\
\hline $6 / 26 / 78$ & Complete construction drawings approved. \\
\hline $5 / 31 / 79$ & Final inspection. \\
\hline $9 / 79$ & Start of service. \\
\hline
\end{tabular}


neither the ERA nor the COE was required to approve the Northwest pipeline project, whereas for the marine terminal projects reviewed such approvals were required and were for the most part conducted in series with the FERC's review. 
2-1. Liquefied Energy Gases Safety, U.S. General Accounting office, EMD-78-28, July 31, 1978.

2-2. Transportation of Liquefied Natural Gas, Congress of the United States, Office of Technology Assessment, September 1977.

2-3. LNG and LPG Hazards Management in Washington State, Oceanographic Institute of Washington, December 1978.

2-4. Desteese, J. G., and Geffen, C. A., Energy Material Transport Now Through 2000: System Characteristics and Potential Problems, Pacific Northwest Laboratory, Battelle Memorial Institute, PNL-2422/UC-71, July 1978.

2-5. "Liquefied Natural Gas Facilities; Federal Safety Standards," Federal Register, Vol. 44, No. 28, February 8 , 1979 .

2-6. Liquefied Natural Gas, Laws and Practices, Policy and Safety, U.S. Coast Guard, Department of Transportation, CG-478, February 1, 1976 .

2-7. Delegation Orders, Department of Energy to the Administrator of the Economic Regulatory Administration and to the Federal Energy Regulatory Commission, signed by James R. Schlesinger, undated.

2-8. Permit Program, A Guide for Applicants, U.S. Army Corps of Engineers, EP 1145-2-1, November 1, 1977.

2-9. "Regulatory Program of the Corps of Engineers," Federal Register, Vol.. 42, No. 138, July 19, 1977.

2-10. "Opinion and Order on Importation of Liquefied Natural Gas from Indonesia," DOE/ERA Opinion Number one, ERA Docket No. 77-001-LNG, December 30, 1977.

2-11. Levy, Max M., "The Cove Point LNG Terminal: Its First Year of Operation," presented at the United Nations Economic Commission for Europe Seminar on LNG Peakshaving, March 1979.

2-12. "Opinion and order on Application to Import LNG from Algeria," DOE/ERA Opinion Number Four, ERA Docket No. 77-006-LNG, December 21, 1978. 


\section{REFERENCES FOR SECTION II (CONCLUDED)}

2-13. Final Environmental Impact Statement, Matagordo Bay project, Federal Power Commission, CP77-330, September 1977.

2-14. Final Environmental Impact statement, Western LNG Project, Federal Energy Regulatory Comission, FERC/EIS$0002 \mathrm{~F}$, October 1978 .

2-15. "Opinion on Rehearing-Issues Related to Treatment of Costs, Safety, and Siting," DOE/ERA Opinion Number Six, ERA Docket No. 77-001-LNG, April 24, 1979.

2-16. Draft Environment Impact Report for Proposed Point Conception LNG Project, state of California Public Utilities Commission, February 28, 1978.

2-17. Daniels, E. J., and Sen, C. T., LNG Peakshaving: Its Role in the United States, Institute of Gas Technology, March 1979. 


\section{LNG SAFETY INFORMATION FOR REGULATORY PURPOSES}

\section{INTRODUCTION}

Basic safety information is, of course, useful not only for analyses and standards prepared by regulatory agencies, but also for LNG facility and vessel designers, owners, and operators. Indeed, common safety models and data are often used by the gas industry and the government. To obtain a current statement of what further technical information is desired and what the perceived uncertainties are in the available predictive methods in the opinions of regulatory agencies, the gas industry and researchers, RDA held discussions with a number of groups and individuals. Included were the USCG, OPSR, FERC, the National Fire Protection Association (NFPA), the American Gas Association (AGA), the Gas Research Institute (GRI), a number of university professors, consulting research organizations, and a number of gas company representatives involved with LNG. In addition, LNG standards prepared by government agencies, and state laws specifically applicable to LNG were reviewed. The purpose was to obtain a cross section of current thinking and not to make a comprehensive survey. The findings relating primarily to public safety are summarized below.

\section{FEDERAL AND STATE REGULATIONS}

a. Office of Pipeline Safety Regulations--On February 11 , 1980, the Materials: Transportation Bureau of DOT published a set of federal safety standards for LNG facilities (Ref. 3-1), which followed by about a year a previous notice of proposed rule making (NPRM). These new OPSR LNG safety standards, effective March 15, 1980, form a new Part 193 of Title 49 of the Code of Federal Regulations (49 CFR Part 193), covering primarily public safety for both peakshaving facilities and the facilities portion of marine terminals. (As indicated in 
Section II, through a Memorandum of Understanding (MU) between the USCG and MTB, the USCG has jurisdiction over marine facilities from the sea up to the last flange connecting the LNG transfer lines to the shore-based storage tanks, in addition to fire protection and security for the entire water-front operations.) The previous Federal safety standards governing LNG, 49 CFR Part 192, adopted as an interim measure the National Fire Protection Association (NFPA) Standard 59A on LNG safety. In the new safety standards OPSR incorporates only a portion of NFPA 59A, 1979 edition, and presents its own standards for exclusion distances required for public safety from thermal effects. The major proposed exclusions distance requirements are:

- Thermal radiation exclusion zones for a pool fire over a spill in an impoundment area are to be computed by a simple model, specified in the standards, which accounts for differences in elevation between the LNG impoundment and the off-site "target" and allows for flame tilt due to wind. The angle of tilt can be taken as 45 degrees, or calculated by a model using a wind speed exceeded less than 5 percent of the time at the site, and approved by the Director of MTB: The flame length is taken as 3 times the hydraulic diameter of the impoundment area. The exclusion distance, $d$, is measured from the tip of the flame horizontally to the target or along a line perpendicular to the edge of the flame to the target, depending upon the geometry. The exclusion distance is determined by the formula:

$$
\mathrm{d}=\mathrm{fA}^{0.5}
$$

where $A \equiv$ largest horizontal area of the impoundment, $f \equiv$ a factor with assigned values of $3,1.6$, 1.1 or 0.8 , depending upon target type, for six classes of targets.

The simple model given is designed to limit the thermal flux incident on six classes of targets to values ranging from $5 \mathrm{~kW} / \mathrm{m}^{2}$ (1600 BTU/ft ${ }^{2}-\mathrm{hr}$ ) for outdoor areas occupied by 20 persons or more (class 1 target) to as $\mathrm{high}$ as $31 \mathrm{~kW} / \mathrm{m}^{2}\left(10,000 \mathrm{BTU} / \mathrm{ft}^{2}-\mathrm{hr}\right)$ 
for class-6 targets (certain buildings, and the property line).

Alternatively, d may be determined by a model using statistical data for atmospheric conditions provided that the model has been experimentally verified and approved by the Director of MTB. The alternative model must assure that the incident flux levels do not exceed those specified in the standard for the six classes of targets.

- Flammable vapor exclusion zones are required so that flammable vapors are prevented from reaching six classes of targets (outdoor areas normally occupied by 20 or more persons, and five types of buildings), except where a planned control method is approved by the Director of MTB.. The method to be used for computing the vapor dispersion is specified as that presented in Appendix B of Reference 3-3. [We note that this is one of the simplest line-source Gaussian: models and was intended only for use in comparing vapor alleviation methods.] The average gas concentration in air at the exclusion zone boundary is to be no greater than 2.5 percent (presumably by volume) on the plume centerline. The weather conditions to be used are specified as those which "result in longer predicted downwind dispersion distances than other weather conditions at the site at least 90 percent of the time, based on U.S. government weather data..." Credit is apparently allowed for vaporization rate reduction with time after the impounding floor is covered by LNG, coupled with vapor detention by the dike walls. The LNG vaporization rate to be used in the vapor dispersion calculations is specified in considerable detail. The spill is taken as the greatest overall flow capacity from an asisumed rupture of a single transfer pipe or multiple pipes where parallel flow is not prevented. The flow time is to be not less than 10 minutes plus additional time (for side or bottom penetration of the tank by the line) for the differential head acting on the opening to reach zero.

Alternatively, the vapor exclusion zone may be calculated by a model which has been experimentally verified and approved by the Director of MTB. Also, where the model used gives larger distances at lower windspeeds, a category-F atmosphere with $4.5 \mathrm{mph}$ windspeed, 50 percent relative humidity and $0^{\circ} \mathrm{C}$ may be used in lieu of the "90 percent" weather conditions quoted above. 
ING vapor explosion is not addressed specifically in the standard; however, a rule is included which requires that storage tanks with an air space beneath the tank bottom be designed to withstand the forces caused by the ignition of a combustible vapor cloud in that space. The concern apparently is that a detonation or strong non-ideal explosion might occur in vapors leaked into the partially confined space and cause structural failure of the tank.

b. United States Coast Guard Regulations--The USCG has published comprehensive safety rules and regulations covering the design, inspection, construction, equipment, operation, maintenance, and repair of vessels carrying hazardous liquids. The most recent of these publications with direct applicability to LNG was published in the Federal Register on May 3, 1979 (Ref. 3-2). It was preceded by "Proposed Standards for Selfpropelled Vessels Carrying Bulk Liquefied Gas," published in Part II of the October 4, 1976 Federal Register. These rules apply to public safety in that they seek to prevent accidental release of hazardous liquid throughout the entire spectrum of the vessels' lifetimes from design throughout all intermediate steps and all aspects of their utilization. Provisions are made for minimizing the volume of any accidental spills from transfer lines, by requiring quick-closing shut-off valves to "close from the open position in at least 30 seconds or less." other active and passive measures are required for mitigating the effects of spills on the deck, including the use of protective materials under possible spill points in the liquid transfer piping and the provision of fire-fighting and protection equipment, such as dry chemical systems, high-expansion foams, and water spray. While survival damage requirements are specified for the vessels there is no specification of accidental spill sizes such as those given in the OPSR NPRM. However, although not a regulation, the USCG has stated in 
Reference 3-3 that the spill of the contents of one tank on an ING vessel represents the maximum credible spill.

The USCG published an Advanced Notice of Proposed Rulemaking for LNG facilities in August 1978 (Ref. 3-4). These proposed standards incorporate parts of NFPA 59A, 1975 edition and present a number of clearance distances. Those pertinent to this work propose that:

- No berthed LNG vessel may be within $50 \mathrm{~m}$ or " $\mathrm{d}$ ", whichever is greater, of the edge of the impoinding space surrounding the shore-based LNG storage tanks, with

$$
d=0.8 \sqrt{A}
$$

where $A \equiv$ inside area, measured across the top of the impounding space.

- ING loading flanges must be located at least $305 \mathrm{~m}$ from the following structures which are primarily intended for the use of the general public or railways :

1) Each bridge crossing a navigable waterway.

2) Each entrance to or superstructure of a vehicular tunnel under a navigable waterway.

c. FERC safety analyses for environmental impact statements--Although the safety analyses performed by the FERC EIS staff (Staff) in preparing their EIS in response to an application for a given LNG project do not officially constitute a standard or formal regulation, the effect of such analyses is in fact regulatory, in that the results are considered in the FERC approval process. Therefore, we shall summarize the FERC staff safety analysis.

siting, safety and mitigating measures constitute the most important aspects of the staff analyses. Any analyses done for land-based spills are performed on a deterministic 
basis. However, their main safety investigation is a public risk analysis performed for a spill from an LNG tanker ship. This analysis considers four conditional probabilities together with an assumed spill size, models for vapor dispersion and ignition and pool fire radiation, and the population in the vicinity of the terminal. These four probabilities are:

- The annual probability of an accident occurring to an LNG tanker while in transit.

- The probability of a spill of LNG occurring in the event of a tanker accident.

- The probability of the formation of a flammable vapor cloud or an LNG pool fire.

- The probability of a fatality resulting from exposure to a flammable vapor cloud ox radiation from a pool fire.

The product of these four probabilities and the number of persons in the vicinity gives the expected fatalities per year. The first two probability values are established from USCG historical data on marine casualties, with allowances made for the superior construction of LNG tankers and for mitigating measures, such as the use of vessel traffic systems (when appropriate). Statistics on the type of casualty (collisions, rammings, and groundings) are used and a casualty probability is estimated for the port of interest. Historical data on accidental spills from tankers (other than LNG) are used to estimate the probability of spill vs size and the type of casualty accident. The waterway bottom characteristics are considered and a maximum credible spill is estimated along with its probability of occurance.

The probability of ignition of the vapor cloud at the. spill point is taken to be 0.9 , and the staff feels that this is conservative for the drifted vapor cloud analysis (Ref. 3-5).

For the last item, the Staff uses models for pool fire radiation and vapor cloud dispersion along with the probability 
of ignition for the latter to complete the four probability values needed. A radiant flux of $5,300 \mathrm{BTU} / \mathrm{ft}^{2}-\mathrm{hr}$ for a period of $5 \mathrm{~s}$ is used as the criterion for fatalities for pool fires. It is assumed that 20 percent of the population. within.this area will be fatalities. The usual tilted cylinder model is used for the radiating flame and for large flames the diameter is calculated by the Raj and Kalelkar liquid-spreading method. A radiating power of $45,000 \mathrm{BTU} / \mathrm{ft}^{2}-\mathrm{hr}$ is used and the flame height, $L$, is calculated using the formula,

$$
L_{1} / D=\left[\frac{\dot{\mathrm{m}}^{\prime \prime}}{\rho_{\mathrm{a}} \mathrm{gD}}\right]^{-0.19}
$$

where $\dot{\mathrm{m}}^{\prime \prime} \equiv$ LNG boiloff rate, perr unit area,

$D$ D burning pool diameter,

$\rho_{a} \equiv$ air density, and

g $\equiv$ gravitational constant.

(We note that this formula is questionable in that $\mathrm{L} / \mathrm{D}$ increases with flame diameter in contrast to other work on the subject.) Allowance is made for atmospheric attenuation on a black-body basis. :

The Staff considers the drifted vapor cloud to present the greatest hazard to the public under most conditions. They normally use their own model for predicting the extent of the combustible cloud. This is a very approximate model in which gravity spreading is allowed but no air entrainment is included during the spreading. Heat transfer from the water and air is introduced to create a neutrally buoyant cloud which then is caused to mix as it drifts downwind by use of a virtual pointsource technique and Gaussian passive dispersion coefficients for a neutrally stable atmosphere and $5 \mathrm{mph}$ wind speed. The results usually show smaller dispersion distances than most 
other models. However, the Staff has stated that the "great disparity among the various models must be considered in an objective determination of public risk," and has modified its procedure to consider a range of wind speeds and stability classes together with a modification to the vapor release rate used in their model. The results, for example, predict 5 percent (average) gas concentration dispersion distances of $5.9 \mathrm{~km}$ (stability D) and $27.1 \mathrm{~km} \mathrm{(stability} \mathrm{F)} \mathrm{for} \mathrm{a} 30,000 \mathrm{~m}^{3}$ LNG spill on water at a wind speed of 4-6 kts. This is to be compared to $1.3 \mathrm{~km}$ for the original one-wind-speed, one stability class procedure. The probability of cloud ignition by a single ignition source is taken as 1 percent, and the number of ignition sources per $\mathrm{km}^{2}$ is determined for the area under study. Together with wind roses and atmosphere stability data for the area, the dispersion predictions and ignition probability are used to predict the fatalities for the area. All persons located within the combustible cloud upon its ignition are counted as fatalities. It is assumed that thermal radiation outside the burning vapor plane is negligible. An individual risk of $10^{-7}$ per year is generally considered acceptable by the staff and $10^{-5}$ is not.

The Staff approach, depending as it does upon physical models of vapor dispersion and pool fire radiation coupled with a number of event probabilities, might suggest a need for research to establish with greater confidence at least some of the probabilities used. It also appears that the staff has little confidence in the accuracy of vapor dispersion models. They seem to be faced with having to make "conservative" judgements on physical models as well as on a number of the event probabilities.

d. State of California--The California legislature passed what they referred to as an "emergency act" in 1977 (Ref. 3-6), which permitted construction of one LNG terminal in the state 
and gave specific population exclusion zones for protecting the population from accidental spills. The key provisions of this act are:

(1) Population density shall be not greater than an average of 10 persons per square mile for a distance of one mile outside the perimeter of the site on which the offloading, regasification, and storage facilities for LNG will be located.

(2) Population density shall be not greater than an average of 60 persons per square mile for a distance of four miles outside the perimeter of the site on which the offloading, regasification, and storage facilities for LNG will be located.

(3) The terminal shall be located so that no marine vessel transporting LNG would be required or permitted in the normal course of marine operations, according to the plan of operations filed by the applicant pursuant to subdivision (b) of section 5601 , to pass closer to areas of population density than the distances specified in paragraphs (1) and (2),

The act required that the terminal be constructed on land in a location remote from population. It also required the California Public Utilities Commission to adopt regulations governing the safety and construction of the terminal.

The CPUC published said regulations effecțive July 5, 1979 (Ref. 3-7). The safety standards require a thermal radiation exclusion zone based on $1600 \mathrm{BTU}_{\mathrm{ft}}{ }^{2} \mathrm{hr}$ or less at the property line that can be built upon. This exclusion distance, $d$, is to be complied with by using the equation,

$$
d=4 A^{0.5}
$$

where $A \equiv$ surface area of impounded LNG measured across the top of the impounding volume,

or by an analysis acceptable to the CPUC in which a wind speed is used which is the highest wind speed that is exceeded 
10 percent of the time at the site, and an ambient humidity which is the absolute humidity that is exceeded 90 percent of the time. at the site. In no case can the distance be less than 50 feet, and any flame radiation from the impounded area must not immobilize any berthed LNG marine carrier.

Flammable vapor control requirements define the design spill for each component to be the largest flow possible from any single line for a duration of 10 minutes (or less if demonstrable shutdown provisions are acceptable to CPUC). If distance is the method chosen to mitigate vapor cloud hazards, the exclusion must be calculated by model (s) approved by the commission. Thermal properties of the impounding surfaces must be conservatively estimated or experimentally determined and the predominant combination of wind speed and atmospheric stability at the site must be used. Alternatively, the PasquillGifford $\mathrm{F}$ stability category and a $2 \mathrm{~m} / \mathrm{s}$ wind may be assumed. An average gas concentration of not more than 2.5 percent by volume in air is the criterion to be used for computing exclusion distance. Use of vapor barriers and impoundment surface insulation may be used for vapor control, but they must be capable of withstanding the thermal and mechanical loads of the spill. Each LNG storage tank is to be impounded separately.

We note that the state of California has imposed a unique population density restriction with respect to LNG facility siting on marine tanker routes; however, the CPUC safety standards are similar to those proposed by OPSR, and apparently are less stringent than OPSR's design spill proposal for a seismically active zone.

e. National Fire Protection Association Standard 59A-Although NFPA 59A is not a regulatory standard itself, most LNG regulations include it by reference to some degree. The latest (1979) edition of 59A (Ref. 3-8) contains the following 
thermal radiation criteria for determining the exclusion distance to the property line that can be build upon:

- $1600 \mathrm{BTU} / \mathrm{ft} \mathrm{t}^{2}-\mathrm{hr}\left(5000 \mathrm{~W} / \mathrm{m}^{2}\right)$ :

$$
a_{1}=3 A_{1} 0.5
$$

where $A_{1} \equiv$ impounding surface area for design spill and $d_{1}$ applies to a property line that can be built upon, and

$$
d_{2}=3 A_{2}^{0.5}
$$

where $A_{2} \equiv$ surface area for full storage tank spill and $d_{2}$ applies to areas of outdoor assembly.

- $3000 \mathrm{BTU} / \mathrm{ft}^{2}-\mathrm{hr}\left(9000 \mathrm{~W} / \mathrm{m}^{2}\right)$ :

$$
a_{3}=2 A_{3}^{0.5}
$$

where $A_{3} \equiv$ impounding area for a full tank spill, and $d_{3}$ applies to existing buildings outside the property line used for purposes of assembly, education, health care, residential and penal housing.

- $10,000 \mathrm{BTU} / \mathrm{ft}^{2}-\mathrm{hr}\left(30,000 \mathrm{~W} / \mathrm{m}^{2}\right)$ :

$$
a_{4}=0.8 \mathrm{~A}_{4}^{0.5}
$$

where $A_{4} \equiv$ surface area of impounded LNG where the impounding area is filled with a volume of LNG equal to the total volume of the largest container, or of all containers in the impound area, if no provisions are made to prevent a leak from one causing leakage from another (by chilling or fire damage). 
The proposed change for vapor zone exclusion permits any suitable model to be used for calculating vapor dispersion, indicating that the Project IS-3-1 methods are suitable. (Ref. 3-9). The method should employ the combination of wind speed and atmospheric stability to give the largest dispersion distance that is exceeded. less than 10 percent of the time; alternatively, Pasquill-Gifford F-stability and $2 \mathrm{~m} / \mathrm{s}$ wind speed may be used. Vapor mitigation techniques, both active and passive, may be considered if they are acceptable to the authority having jurisdiction.

\section{PERCEIVED KEY RESEARCH NEEDS}

Discussions with about 20 government and non-government groups and individuals resulted in a rather wide range of opinions on uncertainties in current LNG safety information and what the research needs are. There was almost as much spread in opinions of what the quantitative goals should be for a research program. The ranges of statements on uncertainty factors, F, defined as the highest expected value divided by the lowest, are given in Table 3-1.

The trend in opinions expressed tended to identify vapor dispersion as the problem needing the most research work. Almost all gas industry representatives stressed the need for proven and accepted mitigation methods for LNG facilities for which they could get exclusion zone credit from regulatory agencies. There seemed to be general agreement that too little is known about the combustion dynamics of drifted vapor clouds. Need for research on fireballs was given the lowest priority. Except for one or two, those interviewed would first just like to know whether explosions are credible. opinion was mixed as to whether work should be done to describe and quantify vapor cloud ignition sources and to establish ignition probabilities with more accuracy; some thought nothing meaningful could be accomplished; others thought useful research could be done. 
TABLE 3-1. CURRENTLY PERCEIVED SAFETY PARAMETER UNCERTAINTIES AND RESEARCH GOALS

\begin{tabular}{|c|c|c|}
\hline SAFETY PARAMETER & OPINIONS ON UNCERTAINTY & OPINIONS ON RESEARCH GOALS \\
\hline $\begin{array}{l}\text { WATER SPILLS: } \\
\text { VAPOR, SOURCE RADIUS }\end{array}$ & $F=1.5$ & NEED TO IMPROVE \\
\hline $\begin{array}{l}\text { VAPOR DISPERSION LFL } \\
\text { DISTANCE, CLOUD } \\
\text { WIDTH, HEIGHT }\end{array}$ & $r=1.2$ TO 10 & $\begin{array}{l}\text { - NO IMPROVEMENT NEEDED } \\
\text { - NEED LARGE-SCALE SPILL TESTS } \\
\text { IMPROVEMENT TO F }=2 \text { NEEDED }\end{array}$ \\
\hline YAPOR CLOUD COMBUSTION & $\begin{array}{l}\text { DON'T UNDERSTAND WELL ENOUGH } \\
\text { - }=4 \text { IN DISTANCE TO GIVEN RADIATION } \\
\text { LEVEL }\end{array}$ & $\begin{array}{l}\text { - RADIATION ALONGSIOE CLOUD AEEDED } \\
\text { TO } F=1.5 \text { IN DISTANCE TO GIVEN } \\
\text { FLUX } \\
\text { - NEED LARGE EXPERIMENT }\end{array}$ \\
\hline FIREBALLS & 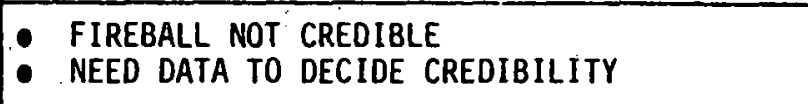 & $\begin{array}{l}\text { - NO RESEARCH NEEDED } \\
\text { NEED LARGE EXPERIMENT }\end{array}$ \\
\hline POÓL FIRES & $\begin{array}{l}\text { - } F=2 \text { ON FLAME RADIATION } \\
\text { AT WHAT SIZE DOES THE FLAME BREAK UP? } \\
\text { FLAME TILT VERSUS WIND SPEED UNCERTAIN } \\
\text { PROBABILITY OF IGNITION AT SPILL RANGES } \\
\text { FROM } 50 \%-99 \%\end{array}$ & $\begin{array}{l}\text { - NEED LARGE EXPERIMENTS } \\
\mathrm{F}=1.1 \mathrm{TO} 1.22\end{array}$ \\
\hline EXPLOSIONS & $\begin{array}{l}\text { - EXPLOSIONS CAN'T OCCUR IN UNCONFINED } \\
\text { CLOUD } \\
\text { - WE NEED TO KNOW IF REASONABLE IGNITION } \\
\text { SOURCE CAN CAUSE EXPLOSION }\end{array}$ & $\begin{array}{l}\text { - NO RESEARCH NEEDED } \\
\text { - RESEARCH NEEDED TO DETERMINE } \\
\text { EFFECTS OF DIFFERENTIAL BOILOFF } \\
\text { AND REASONABLE IGNITION SOURCES }\end{array}$ \\
\hline$\frac{\text { LAND SPILLS: }}{\text { VAPOR SOURCE }}$ & $\begin{array}{l}\text { - UNCERTAINTIES EXIST IN EFFECTIVENESS OF } \\
\text { IMPOUNOMENT INSULATION } \\
\text { - UNCERTAINTY IN DEFINITION OF CATASTROPHIC } \\
\text { SPILLS FOR SAFETY DESIGN } \\
\text { PLANNED IGNITION ACCEPTABLE }\end{array}$ & $\begin{array}{l}\text { - NEED IMPROVED AND PROVEN MITIGATION } \\
\text { METHODS FOR IMPOUNDED AREAS - } \\
\text { THERMAL INSULATION, WETTED AREA } \\
\text { MINIMIZATION, AND ACTIVE MEASURES } \\
\text { TO MINIMIZE VAPOR RELEASE RATE }\end{array}$ \\
\hline
\end{tabular}


TABLE 3-1. CONTINUED

\begin{tabular}{|c|c|c|}
\hline SAFETY PARAMETER & OPINIONS ON UNCERTAINTY & OPINIONS ON RESEARCH GOALS \\
\hline $\begin{array}{l}\text { LANO SPILLS: (cont.) } \\
\text { VAPOR SOURCE (cont.) }\end{array}$ & $\begin{array}{l}\text { - PLANNED IGNITION. A DISASTER } \\
\text { - DIFFERENTIAL BOILOFF DISTRIBUTION } \\
\text { UNCERTAIN } \\
\text { - EFFECTS OF LNG FOAMING IN DIKES ON } \\
\text { BOILOFF UNCERTAIN }\end{array}$ & $\begin{array}{ll}\text { - } & \text { NEED BETTER DEFINITION OF DESIGN } \\
\text { SPILLS } \\
\text { - } \\
\text { ELIMINATE PLANNED IGNITION } \\
\text { ESTABLISH RELIABLE METHODS FOR } \\
\text { PLANNED IGNITION } \\
\text { - BETTER DESCRIPTION OF DIFFERENTIAL } \\
\text { BOILOFF } \\
\text { DETERMINE HOW BOILOFF IS AFFECTED } \\
\text { BY FOAMING AND IF DIKE CAN BOIL- } \\
\text { OVER }\end{array}$ \\
\hline $\begin{array}{l}\text { VAPOR CLOUD DISPERSION } \\
.\end{array}$ & $\begin{array}{l}\text { - } F=2.25 \text { TO } F=1.22 \text { ON DISTANCE TO LFL } \\
\text { - } F=4 \text { ON CONCENTRATION PEAK-TO-MEAN } \\
\text { RATIOS } \\
\text { - EFFECTIVENESS OF ACTIVE VAPOR DISPER- } \\
\text { SION MITIGATION MEASURES UNCERTAIN }\end{array}$ & $\begin{array}{l}\text { NO FURTHER WORK NEEDED } \\
\text { F }=1.22 \text { ON DISTANCE TO LFL } \\
\text { PEAK-TO-MEAN TO F = } 2.25 \text { NEEDED } \\
\text { - EFFECTS OF HIGH EXPANSION FOAM } \\
\text { NEED EVALUATION } \\
\text { - LARGE TESTS NEEDED TO DETERMINE } \\
\text { EFFECTIVENESS OF FOAM AND OTHER } \\
\text { METHODS }\end{array}$ \\
\hline VAPOR CLOUD COMBUSTION & SEE WATER SPILLS & SEE WATER SPILLS, EXCEPT $F=1.2$ \\
\hline FIREBALLS & SEE WATER SPILLS & SEE WATER SPILLS \\
\hline $\begin{array}{c}\text { POOL FIRES } \\
\text {. }\end{array}$ & $\begin{array}{l}\text { - } F=1.2 \text { TO } F=4 \text { ON RANGE TO A GIVEN } \\
\text { LEVEL } \\
\text { - RADIATION FROM ELONGATED POOLS UUNCER- } \\
\text { TAIN }\end{array}$ & $\begin{array}{l}\text { - } M O \text { RESEARCH NEEDED } \\
\text { - }=1.1 \\
\text { SCALE-UP INFORMATION IS NEEDED } \\
\text { ON FOAM AND DRY CHEMICAL EFFEC- } \\
\text { TIVENESS (TRY ON LARGE-SCALE } \\
\text { RADIATION TESTS) } \\
\text { - NEED RADIATION DATA FROM TESTS OF } \\
\text { ELONGATED POOLS TO F } 1.5\end{array}$ \\
\hline
\end{tabular}


TABLE 3-1. CONCLUDED

\begin{tabular}{|c|c|c|}
\hline SAFETY PARAMETER & OPINIONS ON UNCERTAINTY & OPINIONS ON RESEARCH GOALS \\
\hline LAND SPILLS: (cont & & \\
\hline EXPLOSIONS & $\begin{array}{l}\text { EXPLOSION PROBABILITY IS TOO LOW TO BE } \\
\text { OF CONCERN } \\
\text { CAN AN EXPLOSION OCCUR UNOER AN ELEVATED } \\
\text { STORAGE TANK OR BETWEEN A HIGH DIKE WALL } \\
\text { AND THE STORAGE TANK? } \\
\text { IS THERE A CREDIBLE SCENARIO FOR ANY } \\
\text { KIND OF LNG VAPOR CLOUD EXPLOSION? }\end{array}$ & $\begin{array}{l}\text { NO RESEARCH NEEDED } \\
\text { DETERMINE WHETHER SEMI- } \\
\text { CONFINED EXPLOSIONS ARE } \\
\text { CREDIBLE FOR LNG FACILITIES } \\
\text { - DETERMINE IF UNCONFINED VAPOR } \\
\text { CLOUDS CAN CREDIBLY EXPLODE }\end{array}$ \\
\hline
\end{tabular}

\begin{tabular}{c}
$\omega$ \\
\multirow{1}{*}{}
\end{tabular} 
A number of people thought more knowledge is needed on the response of facilities to seismic loads. However, the general opinion was that the necessary research is already under way at a number of universities.

The information obtained in the discussions just summarized was taken into account along with pertinent existing research results in selecting the quantitative' research goals recommended in the following sections. The evaluation of selected mitigating measures is included in the field test work since the opportunity for testing them at such a large scale is rare. The test facilities to be used could provide a test bed for evaluating a wide range of promising mitigation methods if DOE should so choose. A strong sense of industry cooperation and regulatory interest regarding mitigation measures was evident from our discussions. 
3-1. Department of Transportation, Materials Transportation Bureau, "Liquefied Natural Gas Facilities; Federal Safety Standards; Final Rule and Proposed Rulemaking," Federal Register, Vol. 44, No. 28, February 11, 1980, Part II.

3-2. Department of Transportation, U.S. Coast Guard, "Safety Standards for Self-propelled Vessels Carrying Bulk Liquefied Gases; Special Interim Regulations for Issuance of Letters of Compliance to Barges and Existing Liquefied Gas Vessels," 46 CFR, Parts $31,34,40,54,56,98,154$, and 154a, Federal Register, Vol. 44, No. 87, May 3, 1979.

3-3. Liquefied Natural Gas, Views and Practices, Policy and Safety, U.S. Coast Guard, CG-478, February 1, 1976.

3-4. U.S. Coast Guard, "Liquefied Natural Gas Facilities, Advance Notice of Proposed Rulemaking," 33 CFR Part 126 , Federal Register, August 3, 1978.

325. Matagorda Bay Project, Final Environmental Impact statement, Federal Power Commission, CP77-330, September 1977.

3-6. California LNG Act of 1977.

3-7. "Rules Governing Design, Construction, Testing, Maintenance, and Operation of Utility Gas Gathering, Transmission, and Distribution Piping Systems; Revisions of Part I and Part II of General Order No. 112-C and Adopted Part III, Liquefied Natural Gas Facilities Safety Standards of General order No. 112-D," California Public Utilities Commission, adopted June 5, 1979, effective July 5, 1979 .

3-8. Storage and Handling of Liquefied Natural Gas, 1979, National Fire Protection Association, NFPA 59A, 1979.

3-9. LNG Safety Program, Interim Report on Phase II Work, American Gas Association Project Is-3-1, Battelle Columbus Laboratories, July 1, 1974. 


\section{GENERAL FEATURES OF THE RECOMMENDED LNG SAFETY}

RESEARCH PROGRAM

\section{INTRODUCTION}

Over the past 20 years a considerable amount of theoretical and experimental research has been carried out on the potential hazards of accidental LNG spills (Refs. 4-1,4-2). However, because of theoretical difficulties and experimental limitations (discussed in detail in later sections), current knowledge is not sufficient for making accurate, high-confidence predictions of the extent of the danger region should a large accidental spill occur. To cite just two examples: current models of LNG vapor dispersion disagree by up to a factor of 6 in their predictions of the maximum range of the flammable cloud from the rapid spill of an entire ship cargo tank (see Section VI); and recent measurements of the surface radiant flux from LNG pool flames around $12 \mathrm{~m}$ in diameter are up to twice as high as predicted by previously accepted formulas (see Section VII). Accordingly, current policies and regulations concerning safe distances from LNG facilities may be either under- or over-conservative by a significant amount. To improve such policies and regulations, a research program is required that will develop, as rapidly as possible, reliable techniques for predicting the extent of the hazards from large LNG spills.

In this document we describe such a program, which would make use of currently available information and basic scaling laws to plan and carry out quickly a number of small-scale experiments (including wind-tunnel tests), and then would proceed rapidly to relatively large field tests. These experimental investigations would be supplemented by a considerable amount of concurrent mathematical modeling to assist in extrapolating the laboratory and field-test data to much larger 
spills, and to treat spill situations too difficult or numerous to include in the experimental tests. In this way, it is believed that the most important LNG safety questions can be answered in about three years.

\section{2. "RAPID" VERSUS "GRADUAL" RESEARCH APPROACH}

In research or development programs that are expected to culminate in large-scale tests, it is customary to start with small tests and gradually and systematically work up to large ones. However, with such an approach five or more years would probably be required to answer the practical LNG problems of greatest concern. Fortunately, this procedure does not now appear necessary in ING research, since many of the usual arguments. for a gradual approach do not apply. One common argument for a gradual approach is that it increases the. safety of the experiments and of neighboring persons and property. However, many of the proposed LNG field tests involve deliberate fires and attempted explosions, so a remote site combined with spacing or shielding of the observers adequate for the "worst case" are indispensible. No possible results from smaller tests would justify relaxation of these safety precautions. Moreover, a gradual approach can increase the possibility of accidents, due to the greater number of tests involved and the natural tendency to relax towards the end of a long series.

Another reason advanced for conducting tests of gradually increasing size is that something may be learned from. the smaller ones that causes the redesign or even abandonment of the larger ones. However, we believe that, regardless of the results of such smaller LNG tests, relatively large tests are required to answer with confidence the important safety questions. Moreover, most of the test parameters are set by potential accident scenarios and scaling laws, and would not be changed by the results of smaller tests. It is true that 
results from somewhat smaller tests could aid in the optimum design and placement of instrumentation and in determining the effect of spill size on the relevant physical processes. However, the information available from past tests and from the small experiments, wind tunnel tests and calculations recommended below is believed to be adequate for this purpose. If necessary, a few of the large tests could be repeated in less time and cost than performing many tests of graduated size, since much of the time and cost of the tests is in the site preparation, which is determined primarily by the size of the largest test, and in the instrumentation and data reduction, which vary little with test size.

A final argument is that by performing a number of smaller tests one can vary more parameters and also check the reproducibility of the measurements at a reasonable cost. However, as suggešted above, the cost per test does not decrease very rapidly with size, as long as a site suitable for the larger tests must be prepared anyway and no test is so large that the cost of the LNG itself dominates. More important, the relevance of small tests is questionable because many phenomena that are prominent in large LNG spills play much smaller roles in small spills. These phenomena include the "gravity spreading" of the dense ING vapor, the radiation due to soot in LNG flames, and the possible detonation of a vapor-air cloud (see later sections). Consequently, even detailed and accurate data on small spills are of limited value in predicting the behavior of large spills. Moreover, the general goal of the research program recommended here is not to obtain a detailed'scientific understanding of all the relevant physical processes, but to get engineering answers to the most important practical questions relatively quickly.

It has been suggested that, even if a "rapid" research approach is pursued, it is not feasible to construct a remote 
test site, install extensive instrumentation and carry out a number of large tests within three years. This is probably true if elaborate permanent structures are designed and built, and personnel unfamiliar with conducting large hazardous tests are employed. However, a number of times in the last decade, by employing experienced groups from various government agencies and private industry, the Defense Nuclear Agency has been able to move supplies and equipment (including portable instrumentation trailers) into a desert test site, conduct several tests involving hundreds of tons of high explosives, and move out again in less than nine months.*

\section{HIGH PRIORITY LNG SPILL SITUATIONS}

Many types of hypothetical accidental LNG spills are of possible safety concern. A large spill on water might occur if an LNG ship cargo tank were ruptured, for example by collision with another ship. A large spill on land might occur due to rupture of a storage tank by an earthquake or aircraft. collision. Smaller or slower spills might result from similar but less violent situations, or from the breaking of an LNG transfer line, failure of a valve, or collison of an LNG truck. In these various situations, the LNG might be spilled out onto smooth or rough water, soil, concrete or other materials. The surface material and its topography, as well as the geometry of any neighboring structures such as ships or impoundment dikes, affect both the spread and vaporization of the liquid and the subsequent dispersion of the vapor. The vapor dispersion is also influenced by the wind speed, atmospheric stability and possibly the humidity.

In a three-year research program of reasonable cost, it is not possible to cover specifically all possible combinations of spill size and rate, spill surface, topography and

*Discussion with J. G. Lewis, RDA, April 2, 1980. 
meteorology. Accordingly, it is important to develop general methods for solving such problems and to apply these methods to the situations of greatest practical concern, leaving their application to lower priority situations for possible future work. Generally, the situations of greatest public concern are those involving the largest possible accidental spills, even though such spills are much less likely to occur than smaller spills. Examples are the "instantaneous" spill of the contents of a ship tank on water, or of a storage tank into a diked area. A typical large ship tank contains about $25,000 \mathrm{~m}^{3}$ of LNG and if it is spilled in less than 130 seconds, it spreads essentially like an instantaneous spill (see section v). Assuming a tank height of $20 \mathrm{~m}$, such a spill would require a hole near the tank bottom of about $30 \mathrm{~m}^{2}$ in area; this could conceivably be produced if the LNG ship were struck broadside by another large ship.

The usual "worst case" for a land spill involves the rupture of a large LNG storage tank that is surrounded by a low dike having a broad, flat soil floor or impounding area. In this situation the rate of vapor release is controlled by the dike floor area rather than'by the volume of the spill, as long as the spill is large enough to cover the entire surface rapidly with several centimeters of liquid. For a typical rectangular low dike about $100 \mathrm{~m}$ across, this requires only that a few thousand cubic meters of LNG escape within 10 or $20 \mathrm{~s}$.

A third type of spill, though not à "worst case", is worth treating specifically because it appears less improbable than the massive spills described above. This is a smaller spill due to an accidental rupture of a transfer line between a ship and a storage tank. A typical transfer line on a large LNG ship pumps at a rate of $3000 \mathrm{~m}^{3} / \mathrm{hr}$. If it breaks, an automatic shut-off valve is designed to stop the flow within $30 \mathrm{~s}$ (if 
the operator does not stop it first). Accordingly, a logical case to consider is the spill of $25 \mathrm{~m}^{3}$ of LNG in $30 \mathrm{~s}$, on water beside a ship.

We have also considered treating the spill of the 30- to $40-\mathrm{m}^{3}$ load of an LNG truck. However, there are only about 70 such trucks in the U.S. and their number is unlikely to increase substantially. Moreover, these trucks are very strongly built, and in such accidents as have occurred only one or two small leaks have resulted. Finally, in case of a truck spill the liquid spread and vapor release would be controlled by the specific geometry of the road bed, gutter, etc., so that any single prediction of the hazards would be applicable to only a fraction of the practical situations. For these reasons, we have not included any tests or calculations specifically for LNG truck spills in the recommended research program.

In summary, the three spill situations that we take as representative of the highest priority problems in LNG public safety are a spill of $25,000 \mathrm{~m}^{3}$ on water in less than $130 \mathrm{~s}$ (from the side of an LNG ship), a spill of a few hundred cubic meters (or more) on the flat soil floor of a $95 \times 80 \mathrm{~m}$ lowdike within $20 \mathrm{~s}$, and a spill of $25 \mathrm{~m}^{3}$ on water beside a ship in $30 \mathrm{~s}$.

\section{MITIGATION RESEARCH}

In addition to research for determining with greater confidence the extent of the potential hazards from accidental LNG spills, research that suggests or evaluates possible mitigation methods for reducing the hazards is also of great interest. There is a question, however, as to how much of such research should be supported by the federal government and how much by the LNG industry, which has much to gain if mitigation methods permit reduction of facility exclusion distances or operational restrictions. 
LNG spill hazards can be mitigated if the boiloff rate of the spilled liquid can be reduced. In dike spills this reduction might be accomplished by the use of an insulating material on the dike floor, the use of a high dike with smaller floor area, or (for smaller spills) the use of a sloping dike floor or dike sump (Ref. 4-3). Accordingly, a few vapor-dispersion and pool-fire tests of such configurations are included in the research program described below. We also recommend that an appropriate firefighting organization be invited to try to control or extinguish one of the proposed large test fires.

Other potential mitigation methods are less well developed, and it does not seem appropriate to include them in a highpriority, minimum-time research program supported principally by the U.S. government. 


\section{REFERENCES FOR SECTION IV}

4-1. DeVore, R. V., and Sarkes, L. A., ING Research Programs Sponsored by the American Gas Association., American: Gas Association, January 3, 1977.

4-2. Liquefied Gaseous Fuels Safety and Environmental Control Assessment Program: A Status Report, U.S. Dept. of Energy, DOE/EV-0036, MaY 1979.

4-3. Evaluation of LNG Vapor Control Methods, A. D. Little, Inc., for the American Gas Association, October 1974. 


\section{RECOMMENDED RESEARCH ON LNG SPREADING AND BOILOFF}

\section{INTRODUCTION}

The importance of being able to predict the physical consequences of accidental spills of tens of thousands of cubic meters of LNG on land or water has been explained in section IV. When LNG is spilled, the first physical processes that occur are its spreading over the surrounding surfaces and its rapid boiloff (vaporization) because the surface temperature is much above the boiling temperature of the liquid. Although the spreading liquid could directly damage objects and freeze people in its path, the extent of such a potential hazard is small compared to that arising if the LNG vapor should become ignited to produce a large fire or conceivably an explosion. Consequently, information on LNG spreading and boiloff is needed primarily as input for analyses of LNG vapor dispersion and combustion, as discussed in later sections of this report.

a. Spills on land--A large accidental spill of LNG on land would generally occur only if a large storage tank or connecting fill line were ruptured. Such tanks are invariably surrounded by dikes to confine the liquid. By Bernoulli's well-known theorem, the initial spreading velocity of the LNG across the floor of the dike would equal $\sqrt{2 g h_{0}}$, where $g$ is the acceleration due to gravity and $h_{0}$ is the initial height of the liquid surface in the tank, above the dike floor level. As spreading continues, friction against the dike floor would tend to slow the velocity of the LNG front. However, for the larger spills of greatest safety concern, this slowing can generally be ignored because when the liquid first contacts the surface, film boiling reduces the friction. Calculations of the spread of water (which does not have 
this friction-reducing mechanism) show that little slowing occurs until the water has spread more than a hundred times its initial height (Ref. 5-1). This distance exceeds the dimensions of the largest LNG dikes, so the assumption of constant spreading velocity over the entire dike floor appears justified.

If the dike should be accidentally ruptured at the same time as the tank, the spreading of LNG through the rupture and over the outside terrain would depend upon the detailed geometry of the rupture and terrain. Neglecting friction, this spreading could be calculated by well-established hydraulic principles. For extensive spreading where friction might be significant, accurate predictions cannot currently be made. because no data are available on the frictional coefficient of boiling LNG. However, this problem does not appear to have a high priority.

The rates of LNG boiloff (per unit area) on soil and on several construction materials have been established by a number of measurements in the laboratory and in the field (Ref. 5-2). Typical results are shown in Figure 5-1. Except for corrugated sheet metal, all observed boiloff rates, over times from a few seconds to a few minutes, follow approximately a $t^{-1 / 2}$ law, in agreement with a simple heat conductivity model (Ref. 5-2). The proportionality constant for different soils varies by over a factor of 2, depending upon their moisture content and other characteristics, while that for insulating materials can be over a factor of 10 smaller. Accordingly, it is important to have boiloff or heat conductivity measurements on the exact materials used on full-scale and test dikes. The laboratory experiments also show that differential boiloff of the LNG components generally occurs; i.e., the methane, ethane and propane fractions vaporize successively, in that order. This behavior is important 


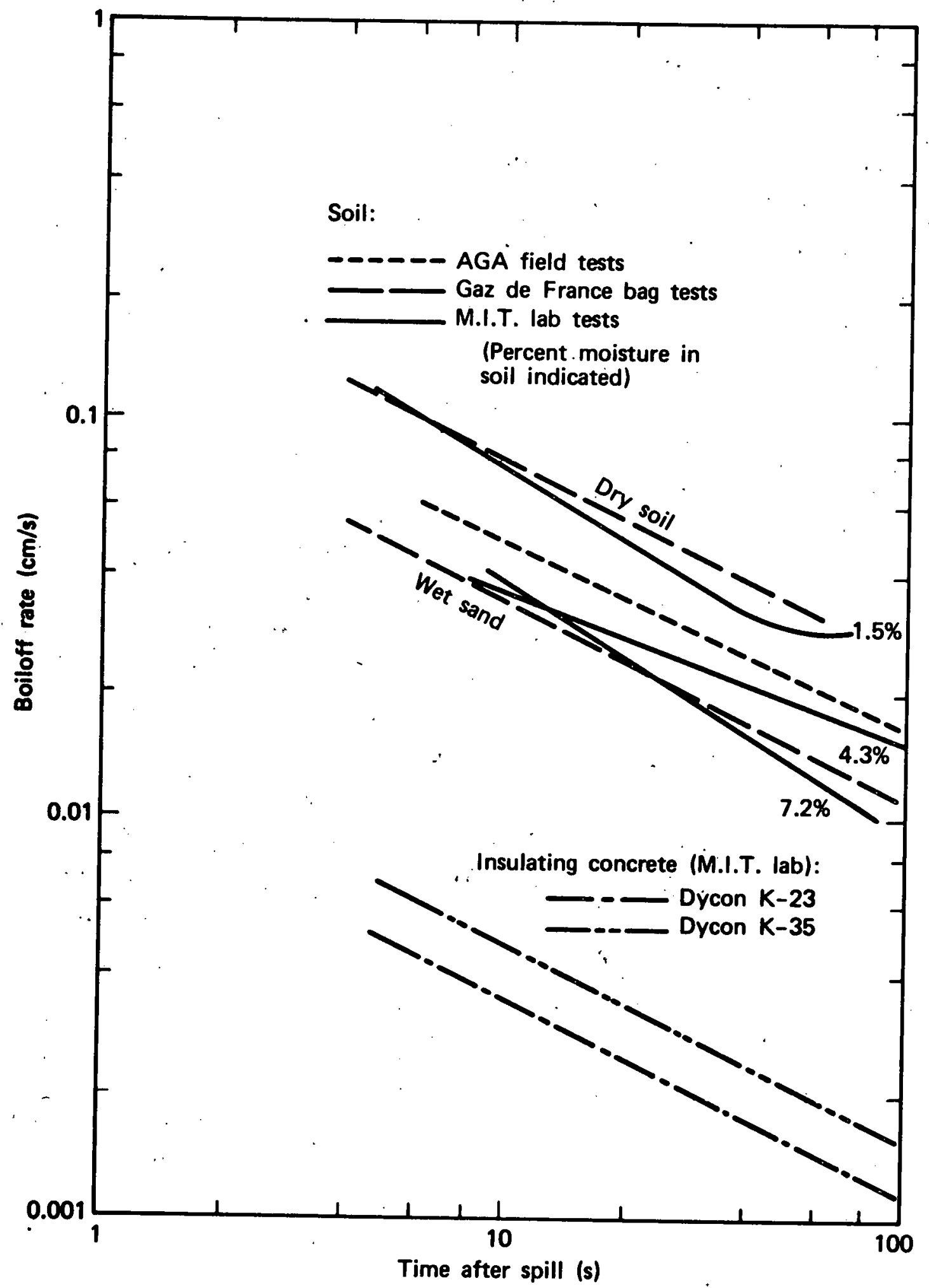

Figure 5-1. Measured boiloff rates of LNG on soil and insulating concrete. 
because the heavier hydrocarbons produce sootier flames (see sections VII and VIII) and are easier to detonate (see Section IX).

b. Spills on water--Possible accidental spills of LNG on water can generally be bounded by two limiting types. The first limit is a spill at a constant or slowly varying rate, such as could be caused by a relatively small puncture of an LNG cargo tank. Small-scale tests have shown that in such a situation the LNG spreads rapidly over the water surface until its total evaporation rate balances its spill rate, after which time the pool area remains roughly constant. In this situation the fluid dynamics of the spreading is of little practical importance. The second limit is a rapid or "instantaneous" spill where a fixed volume of LNG is spilled in a time short compared to its spreading time. This situation might occur if a cargo tank seam failed under stress. In such a situation, small-scale tests show that the resistance of the water, which is partially displaced by the floating LNG (about 42 percent as dense), rapidly slows down the LNG spreading velocity. Experimental spreading data from all known rapid spill tests (Refs. 5-3 to 5-5) are shown on Figure 5-2, normalized by the theoretical maximum pool diameter and duration (Ref. 5-6), to put the different size tests on the same scale. In all of these tests the LNG was rapidly poured from a bucket or pumped from. a spout onto an open area of water; the largest test involved only $1 \mathrm{~m}^{3}$ of LNG. A scatter of about a factor of 1.5 is apparent in the data for the different tests, possibly due to variations in the method of spill and errors introduced by the assumption that the pool size equaled the size of the base of the visible vapor cloud.

Simple models of the radial spreading of $\mathrm{LNG}$ on water have been developed, based on the assumption that the velocity of the LNG front (outer edge) at any time is proportional to 


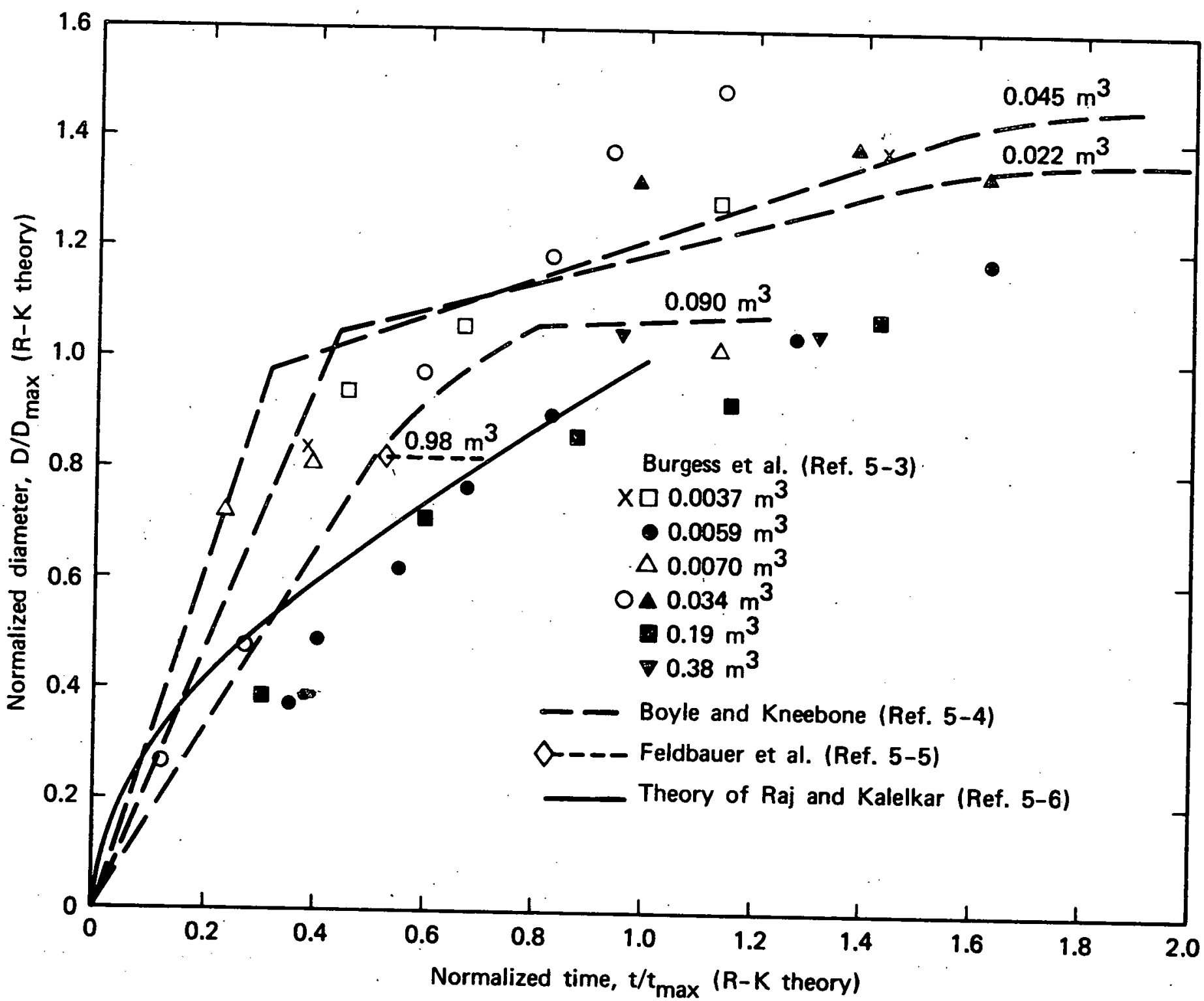

Figure 5-2... Experimental and theoretical diameter vs time for an instantaneous LNG spill on water. 
the square root of the mean height of the LNG pool at that time, with different investigators using slightly different proportionality constants. As pointed out by Hoult in connection with spreading oil spills (Ref. 5-7), the physics of this assumption is not entirely clear, though it does give oil-spreading results in reasonable agreement with laboratory measurements.

The most widely employed model of LNG spreading on water is that of Raj and Kalelkar (Ref. 5-6), which uses a fit to the oil-spread model. Figure 5-2 compares this ING model with the available experimental data. To make this comparison, a value for the mean boiloff rate per unit area must be chosen; the value used was the conventional one of $0.042 \mathrm{~cm} / \mathrm{s}$ (see below). The model curve lies within the spread of the experimental data, but falls below the measurements on most of the larger spills. A better fit could be obtained by decreasing the assumed boiloff rate by about a factor of 2 , except for the largest $\left(0.98 \mathrm{~m}^{3}\right)$ spill, where the data suggest a slight increase instead. It is clear from Figure 5-2 that, until better measurements or theory are available, predictions of the spreading of LNG on water after a rapid spill have an uncertainty range of at least a factor of 1.5, and the uncertainty is probably considerably greater for spills much larger than those tested. In addition, fluid dynamic theory suggests and test photographs show that the LNG becomes thinner and boils away first in the center of the pool, but no quantitative measurements of this effect are available.

Some past test spills have fallen in the middle region between the limits of "steady" and "instantaneous" spills, and this could also be true of accidental spills. In such situations, if the same edge velocity assumption is used as in the "instantaneous" models, the spreading relations can be reduced to a single ordinary differential equation that can be 
integrated numerically. In the special case of a constant spill rate for a finite duration, the solution can be reduced to a quadrature. Figure 5-3 compares calculated results with measurements on two recent constant-r̂te test spills at China Lake (Ref. 5-8). These two spills were ignited to give fire tests, so their boiloff rate is expected to be increased above the nominal $0.042 \mathrm{~cm} / \mathrm{s}$ value by radiant heating from the flames. In fact, from the spill rate and the late steady-state pool radius one can deduce values of 0.073 and $0.045 \mathrm{~cm} / \mathrm{s}$, respectively, for the two spills, and these values were used in the spreading calculations.

A comparison of the calculated pool spreading histories with the measured values (Figure 5-3) shows considerable discrepancies. The early expansion rates are much higher than the theoretical values, and in Test 5 the diameter apparently reached a maximum much earlier than expected (based on the observed size of the moist air cloud, since this was before the flame had vaporized $i t$ ) and then the diameter decreased about 30 percent to a steady value (similar to the behavior predicted for much later times). No maximum was observed on Test 12, which had a spill rate only 25 percent smaller. The surprisingly rapid early expansion rate, several times faster than that measured on previous spill tests, may be due to the fact that the LNG was spilled from a pipe $1 \mathrm{~m}$ above the

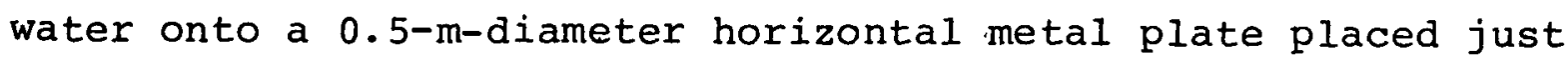
beneath the water surface to keep the LNG from striking the bottom of the shallow pond. It is clear that these new data have not reduced the uncertainties in predictions of LNG spreading during large accidental spills on water.

Recent laboratory experiments and analyses have established the boiloff rate of LNG when the liquid is confined to a limited area by walls (Ref. 5-9). The rate varies with time as the water surface freezes and the ice cools further, and 


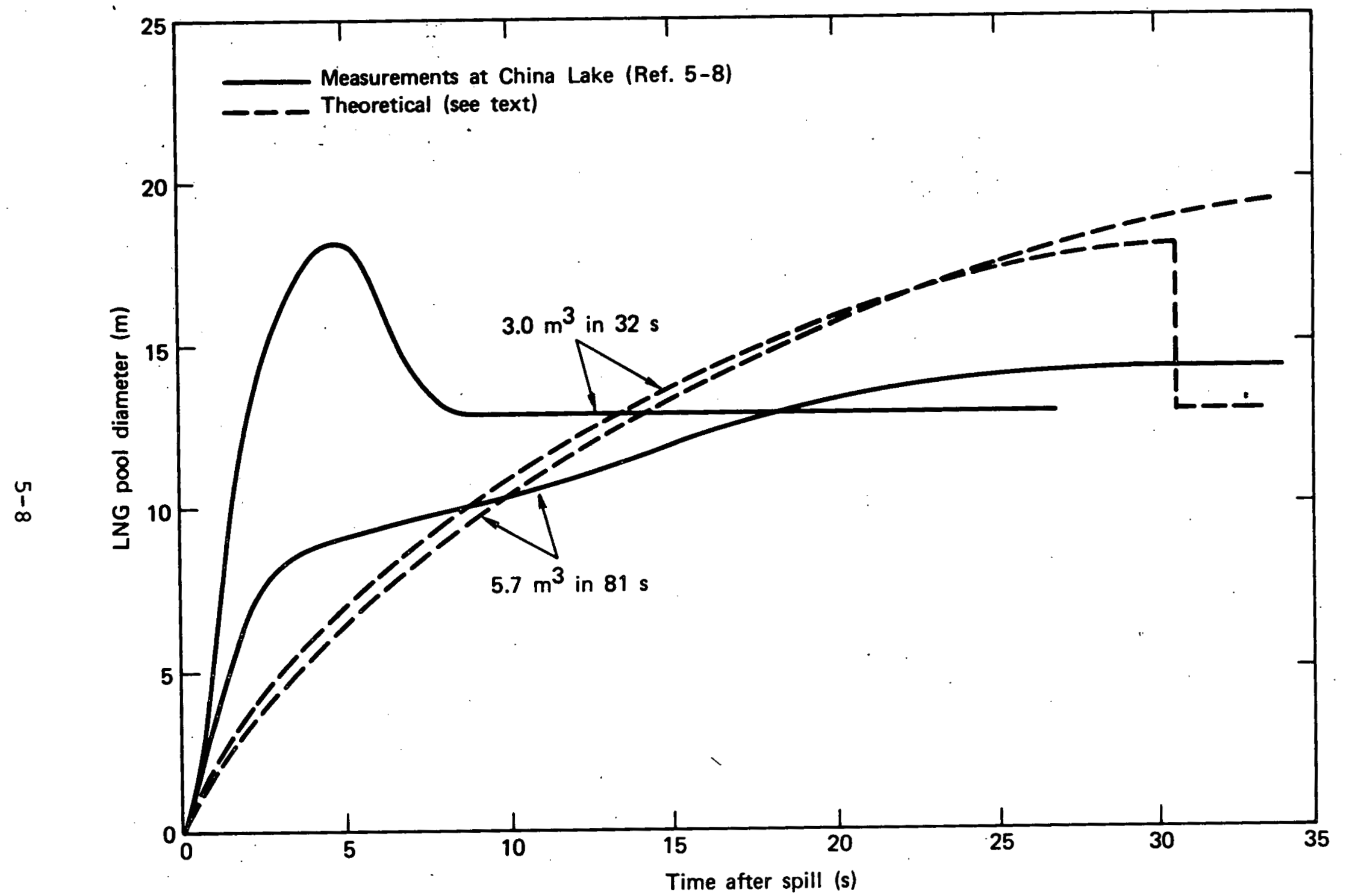

Figure 5-3. Comparison of measured and theoretical LNG pool diameters for two constant-rate spills on water. 
the variation depends upon the concentration of ethane and propane in the LNG. Moreover, the methane, ethane and propane boil off in that order, with little overlap. However, the behavior of unconfined LNG when spilled on open water appears to be different. Tests employing long-duration. steady spills resulted in LNG pools that reached a steady size, implying a constan't boiloff rate per unit area. However, the rate obtained by different investigators varied by a factor of about 7, from 0.007 to $0.05 \mathrm{~cm} / \mathrm{s}$ (Refs. 5-3,5-4); moreover, the group obtaining the smaller rate found it to almost double when the water was particularly calm (Ref. 5-4). No direct measurements of boiloff rates while an LNG pool is expanding are available, but the measured size histories imply that the mean. rates on some rapid spills were over twice those of others, as discussed earlier. In addition, it appears probable that fractionation among the LNG hydrocarbons will be less complete than in the confined situation, because different regions of the pool have different boiling histories. However, the only available measurements of differential boiloff on unconfined water spills were taken on relatively slow spills at points outside the pool (Ref. 5-10), and no theory that allows for spatial variations has been developed.

c. Research goals and approach--The goals of the research recommended in this section are to obtain sufficient information to make confident predictions of the spreading and boiloff characteristics (including differential boiloff) of ignited and unignited spills of up to $25,000 \mathrm{~m}^{3}$ of LNG on water, and the boiloff characteristics of ignited spills in a dike up to about $200 \mathrm{~m}$ across. (It is believed that the spreading and unignited boiloff of LNG on land are already sufficiently well understood for the most important practical purposes.) Since the spreading and boiloff predictions will be used as input for the predictions of vapor dispersion, flame radiation and 
explosion discussed in sections VI to IX, their accuracy must be sufficient to satisfy the quantitative goals stated in the latter sections. Current understanding suggests that a given percentage uncertainty in the spreading or boiloff rate generally leads to a smaller uncertainty in the maximum potential extent of flammable vapor, significant, radiation or significant blast pressure. However, setting of quantitative accuracy goals for spreading and boiloff predictions is left for the early sensitivity studies recommended in sections VI and VII.

The proposed research approach is principally experimental, involving spreading and boiloff measurements during a number of LNG field tests on land and water. A modest amount of theoretical and semiempirical modeling is also included. Details of the recommended research are discussed below.

It may be noted that the same approach and much of the same instrumentation and mathematical modeling could be applied to the subject of LPG safety.

\section{EXPERIMENTS}

a. Scaling requirements for spills on land--In order to simulate precisely the spreading and boiloff of large LNG spills on land by small test spills, it is necessary that all dimensionless combinations of the important physical parameters be the same for the model experiment as for the fullscale situation. The important physical parameters are the characteristic length, $l$ (assuming that all dimensions are scaled by the same factor, so that geometric similarity is preserved), the characteristic velocity, $u$, the acceleration due to gravity, $g$, the liquid density, $\theta$, and the mass boiloff rate per unit area, w. . (As discussed earlier, the LNG viscosity does not enter unless the liquid spreads far beyond the confines of a typical dike.) The only independent 
dimensionless quantities that can be formed from these parameters are the Froude number, $\mathrm{u}^{2} / \mathrm{g} l$, and the dimensionless boiloff rate, $W /(\rho u)$. Since $g$ cannot be varied (except by the expensive procedure of testing within a centrifuge), to preserve the Froude number all velocities must be scaled as the square root of the length scaling, and all times by this same factor, since time is proportional to length divided by velocity.

To preserve the same dimensionless boiloff rate, $W /(\rho u)$, in an experiment where LNG is used (so that $\rho$ is not changed), the boiloff rate $W$ must be reduced by the square root of the length scale reduction. For field tests this is generally not a large reduction; it is only about a factor of 3 when the length scale is reduced by a factor of 10 and hence the required LNG volume by a factor of 1000 below the full-scale. (An even larger reduction in LNG amount is often permissible, since a low dike does not have to be full of LNG to approximate the early post-spill period of maximum boiloff rate.) As shown by Figure 5-1, changes by factors of 2 or 3 may be obtained by varying the type of soil used.

Laboratory or wind-tunnel experiments would require a greater decrease in $\mathrm{w}$. For example, scaling down an actual dike by a linear factor of 1000 for a vapor dispersion test in a moderate-size wind tunnel requires reducing $w$ by a factor of about 30. If LNG is actually spilled in a wind tunnel, $w$ will be proportional to $\left(k \rho_{\mathrm{m}} \mathrm{C}\right)^{1 / 2} \Delta \mathrm{T}$, where $\mathrm{k}, \rho_{\mathrm{m}}$ and $\mathrm{C}$ are the thermal conductivity, density and specific heat of the material on which the LNG is spilled, and $\Delta T$ is the initial temperature difference between this material and the LNG. Insulating materials are available which have values of $\left(k \rho_{m} c\right)^{1 / 2}$ a factor of 30 or so smaller than that for soil or concrete, but not a factor of 30 smaller than that for some of the insulating materials being considered for dike floors, so that simulation of insulated dikes would require 
precooling of the model floor and walls to decrease $\Delta \mathrm{T}$ : (In vapor dispersion experiments, an alternative is to release cold LNG vapor through a perforated floor plate at the correct scaled rate, using an appropriate valve.l

In laboratory and wind-tunnel experiments it would be preferable to simulate LNG by a nonflammable liquid. To properly scale the spreading and boiloff, this simply requires that $W / \rho$ be scaled as $\ell^{1 / 2}$, which appears feasible. However, we believe that the spreading and boiloff of LNG on a solid surface is sufficiently well understood that further small-scale experiments just for this purpose are not required. on the other hand, wind-tunnel tests of vapor dispersion are needed (see section VI), and these require methods for releasing the vapor at the properly scaled rate and over the proper area. Use of flammable fluids is not permissible in some windtunnel test configurations (such as continuous releases in closed-loop tunnels), so a suitable nonflammable substance would be desirable. However, no nonflammable cryogen has the proper ratio of boiloff vapor density to air density, which is important for vapor dispersion. Hence, a satisfactory simulation cannot be attained by spilling a nonflammable cryogen, and any nonflammable simulant would have to be metered and released in the gas phase.

b. Scaling requirements for spills on water--The behavior of LNG spills on water depends upon the same parameters discussed above for land spills, and an additional parameter, the liquid density ratio $\rho / \rho \mathrm{H}_{2} \mathrm{O}$, which will be discussed later. In principle, the viscosity and surface tension of the LNG and water could also be.significant, but experiments show that they play a role only after an LNG pool has become so thin that its remaining lifetime is negligible.

Accordingly, if the boiloff rate could be properly scaled, Froude scaling would hold also for water spills, so that the 
spreading velocities and times would vary as the square root of the length scale. Most spills on water are not, confined to fixed areas by walls, so that their length scale would vary as $\mathrm{V}^{1 / 3}$, where $\mathrm{V}$ is the volume of LNG spilled, and consequently their velocities and times would scale as $\mathrm{v}^{1 / 6}, \because$ As in the case of land spills, the boiloff rate, $W$, should also be scaled as $e^{1 / 2}$ or $\mathrm{v}^{1 / 6}$. However, unlike the land spill situation, a method of changing $w$ by a desired amount is not available. Conceivably, by substituting a different liquid for either the LNG or the water ( $p r$ both), one could obtain an appropriate reduction. On a large or moderate-size test this would be very expensive, especially if a water simulant were used. More important, it would require an extensive initial investigation to determine a suitable pair of simulation liquids. As discussed earlier, even the boiloff rate of unconfined LNG on water is uncertain. Past experiments suggest that, unlike the situation for confined spills or spills on solids, the rate does not decrease with time. However, different experiments have yielded rates differing by up to a factor of 7 , together with evidence that a slightly rippled water surface could decrease the boiloff rate by about a factor of 2 (Ref. 5-4).

Our knowledge about ING boiloff should be considerably improved when more results from recent field tests at China Iake (Refs. 5-8,5-11) and current laboratory tests at M.I.T. (Ref. 5-12) become available. However, the China Lake spills were not very rapid and had limited instrumentation for spreading and boiloff measurements, while the M.I.T. experiments involve very small spills in a one-dimensional channel. Even if the boiloff rate of unconfined LNG on water can be well established, use of a simulant liquid (or liquids) would require additional investigations of its boiloff properties. 
If a simulation liquid were employed, it should also have the same liquid density ratio, $\rho / \rho_{\mathrm{H}_{2} \mathrm{O}}$. For LNG this ratio is about 0.43 , depending slightly on the composition of the LNG and whether the water is fresh or salty. The only nonflammable cryogens lighter than water are liquid helium, nitrogen, ammonia, methyl fluoride and methyl chloride, which have density ratios of $0.15,0.81,0.77,0.84$ and 0.91 , respectively. None of these values is close to that for LNG. (This is also true of the much longer list of Ilammable cryogens.) Moreover, the boiling temperature of helium is much lower than that of LNG, while that of the other liquids, except nitrogen, is much higher. In small laboratory experiments it might be possible to utilize spills of liquid nitrogen on an aqueous solution containing enough of a heavy salt to give the desired liquid density ratio, but for larger tests the costs of the salt could be prohibitive. In addition, the boiloff rate of liquid nitrogen on water depends upon the liquid depth, while that for LNG does not, at least for confined spills (Ref. 5-13) so the simulation would be accurate only for the earlier part of the liquid spreading, when the boiloff is not very important. Finally, no simulant liquid would give information on the differential boiloff of the different hydrocarbon components of LNG.

Another way in which one might change the effective boiloff rate (without using a simulation liquid) is to cover a fraction of the water surface with floats or barriers to prevent the LNG from flowing over that portion of the surface. However, even if the hydrodynamic drag of these barriers is negligible, they influence the ING flow by an exclided-volume effect. Consequently, this method permits either scaling the maximum pool diameter or the maximum boiloff rate, but not both. Its use is therefore not recommended. 
In view of the difficulties of changing $w$ in a subscale simulation of an LNG spill on water, it is worth considering carefully the consequences of not scaling $w$. In simulating a hypothetical $25,000-\mathrm{m}^{3}$ LNG spill by a $350-\mathrm{m}^{3}$ test spill, the desired reduction in $W$ is only a factor of $(25,000 / 350)^{1 / 6}=2$, which is apparently comparable to the change in $\mathrm{W}$ caused by small water waves. According to theory (Ref. 5-6), a factor of 2 change in $W$ changes the maximum diameter of an LNG pool by only a factor of $2^{-1 / 4}=0.8$, and the total boiloff rate by a factor of $2 \cdot 2^{-1 / 2}=1.4$. These are not very serious changes, especially since the important practical quantities, such as the downwind flammable-vapor distance or pool-fire height, vary less than linearly with these parameters. Information from the research work recommended in the later sections should allow one to correct for such minor deviations.

In wind-tunnel tests the scale-down factor for $\mathrm{W}$ is much greater, so that simulation by actually pouring LNG on water in a wind tunnel would not give a suitable boiloff rate. Instead, special valves and rotating plates with offset perforations (or an equivalent scheme) should be designed to release cold natural gas or a simulant gas at the proper rate over the properly varying area. An alternative would be the metered release of LNG at the center of a solid constanttemperature surface (such as a heavy copper plate, or a copper. sheet above an antifreeze liquid reservoir) maintained cold enough to reduce the boiloff rate to the desired value.

c. "Swimming pool" tests--As explained above, significant uncertainties currently exist in the spreading and boiloff of LNG on water, which require further experimental investigation. Recent spills of a few cubic meters of LNG on a pond at china Lake (Refs. 5-8,5-11) have given some information on these subjects. However, aside from vapor sampling bottles on some of the tests, relevant instrumentation was limited to overhead 
photography. Generally, the view of the cameras was somewhat obscured by the fog produced over the cold LNG pool by condensation of moisture in the air, except when the pool was ignited, but in the latter situation radiation from the flames increased the boiloff rate. The instrumentation on the current laboratory experiments at M.I.T. is more complete, including thermocouples at the water surface, vapor sampling bottles at eight different positions, and photography from top and side (Ref. 5-12). However, the spills are small $\left(0.003 \mathrm{~m}^{3}\right)$, the spreading is linear rather than radial, and the small trough width and depth may promote freezing of the water (as in a confined spill). Moreover, there are no plans at M.I.T. to investigate the effects of parameters such as spill height, horizontal velocity of spill, water depth, water waves or surface obstacles (such as ship hulls).

In order to investigate these effects at a reasonable cost and quickly enough to provide inputs for at least some of the mathematical models and wind-tunnel and field tests of LNG vapor dispersion, we recommend that a series of spill tests in a swimming pool or equivalent body of water be performed at the outset of the general research program. The specific objectives of these tests would be to determine the spreading and boiloff rates of rapid unconfined LNG spills large enough so that viscosity and surface tension are clearly unimportant, and to determine whether these rates are significantly affected by spill height, horizontal velocity of the spilled liquid, water depth, water waves, or simulated ship hulls.

A sketch of a pool suitable for these tests is shown in Figure 5-4. The diameter of $25 \mathrm{~m}$ is chosen to give a construction cost that is only a fraction of the cost of a well-instrumented test series. The depth of the pool is determined by the need to photograph the spreading LNG with 


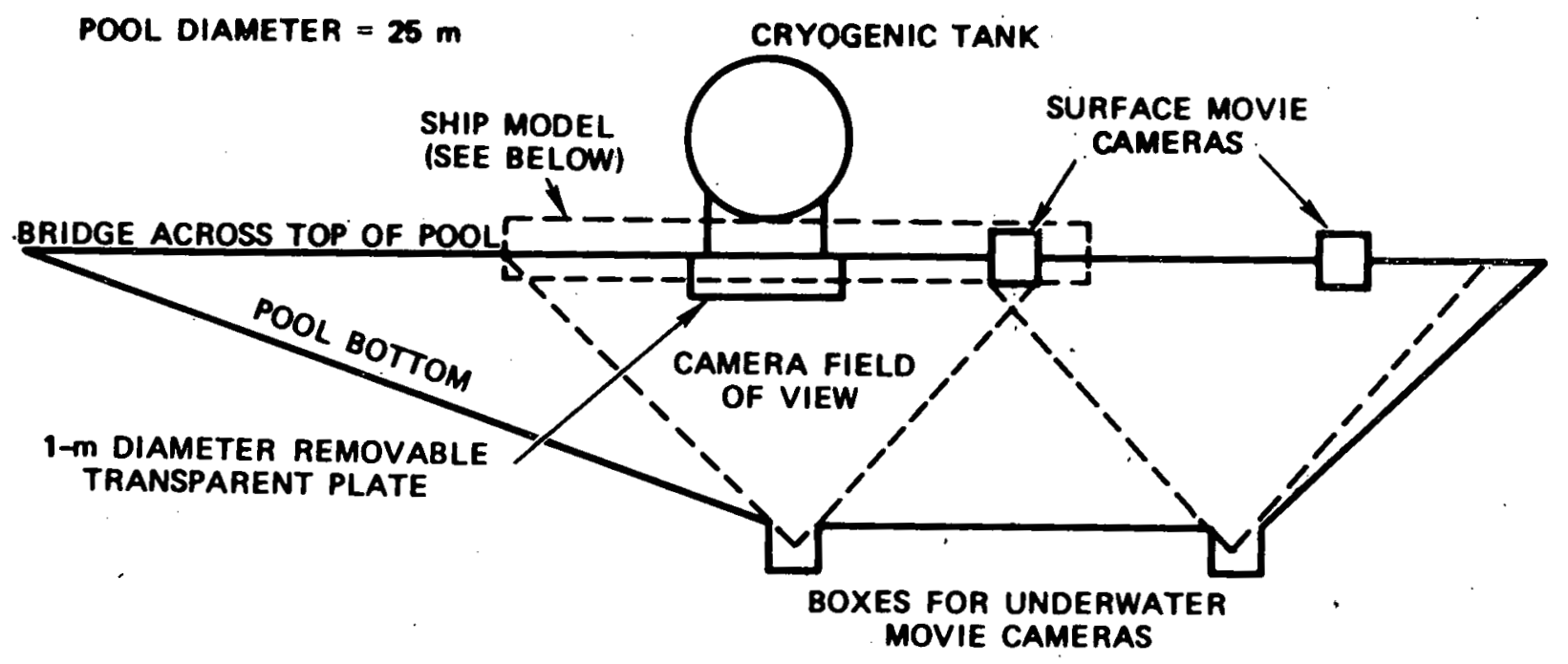

TOP VIEW OF SHIP MODEL

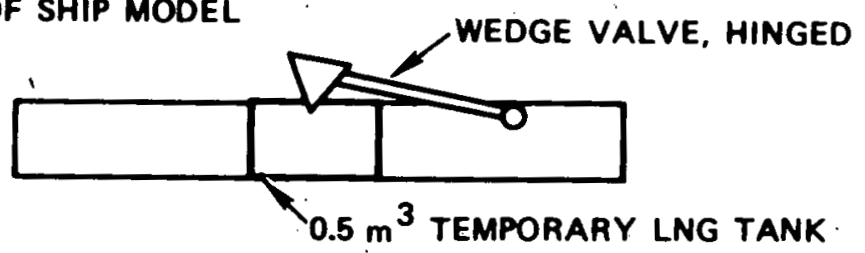

Figure 5-4. Sketch of swimming pool installation (side view) and ship model 
a limited number of underwater movie cameras, since the view of overhead cameras will probably be obscured by the condensed moisture clouds produced when the cold LNG vapor comes into contact with moist air. A remotely located pool that is quite adequate for such tests is available at Sandia Base, near Albuquerque, NM. ${ }^{*}$ This pool, which was built by the Lovelace Foundation for the U.S. Navy and is currently not in use, is about $70 \mathrm{~m}$ long, $50 \mathrm{~m}$ wide and $10 \mathrm{~m}$ deep; it is lined with a rubberized material that may require some repairs. Its greater depth, compared to the pool shown in Figure 5-4, would probably permit reduction in the number of underwater cameras required. It is equipped with a filter system to clarify the water.

The largest spill that can be accommodated in a 25-m-diameter pool can be estimated from the results of the Raj and Kalelkar theory. (Ref. 5-6) shown in Figure 5-5. Allowing a safety factor of 1.4 in the maximum diameter because of uncertainties in the theory (see Figure 5-2), and decreasing the spill volume by a factor of 2 to cover tests where the LNG is confined to half of the pool by a barrier representing a ship hull, one obtains an allowable spill size of $0.5 \mathrm{~m}^{3}$.

The recommended swimming pool tests are listed in Table 5-1. Most of the tests involve very rapid spills, since such spills are of greatest concern to public safety. It can be shown by integration of the spreading equations for constant spill rates that if the spill duration is less than half of the pool lifetime of an instantaneous spill of the same volume (Figure 5-5), the maximum area and total

*Discussion with D. Richmond, Lovelace Foundation, and L. J. Vortman, Sandia Corp., 29 August 1979. 
TABLE 5-1. "SWIMMING POOL" TEST PROGRAM

\begin{tabular}{|c|c|c|c|c|c|c|}
\hline $\begin{array}{l}\text { Test } \\
\text { no. }\end{array}$ & $\begin{array}{l}\text { Spill } \\
\text { vol. } \\
\left(\mathrm{m}^{3}\right)\end{array}$ & $\begin{array}{l}\text { Spill time } \\
\text { (s) }\end{array}$ & $\begin{array}{l}\text { Eff. head of } \\
\text { LNG } \\
(\mathrm{m})^{*}\end{array}$ & $\begin{array}{l}\text { Ship } \\
\text { model }\end{array}$ & $\begin{array}{l}\text { Transpar. } \\
\text { deflector }\end{array}$ & $\begin{array}{c}\text { Wave } \\
\text { generator }\end{array}$ \\
\hline $1-2$ & 0.5 & $<8$ & 2 & None & No & Off/on \\
\hline $3-4$ & & & 2 & & Yes & Off/on \\
\hline $5-6$ & & & Min. feas. & & Yes & Off/on \\
\hline $7-8$ & & & & & No & Off/on \\
\hline $9-10$ & & & & $\begin{array}{l}\text { Collid. } \\
\text { ships }\end{array}$ & No & Off/on \\
\hline $11-12$ & & & & & Yes & Off/on \\
\hline $13-14$ & & "Ship tank" & "Ship tank" & & Yes & Off/on \\
\hline $15-16$ & & "Ship tank" & "Ship tank" & & No & Off/on \\
\hline $17-18$ & & 18 & 4.3 & 1 ship & No & Off/on \\
\hline $19-28$ & \multicolumn{6}{|c|}{$\begin{array}{l}\text { Contingency tests, parameters to be determined by the results of the } \\
\text { preceding tests. }\end{array}$} \\
\hline
\end{tabular}

"Mean height of the LNG surface in the spill tank, above the water surface, during the spill. For the higher values, the tank may be either raised up or pressurized to give the equivalent vertical velocity as the liquid enters
the water. 


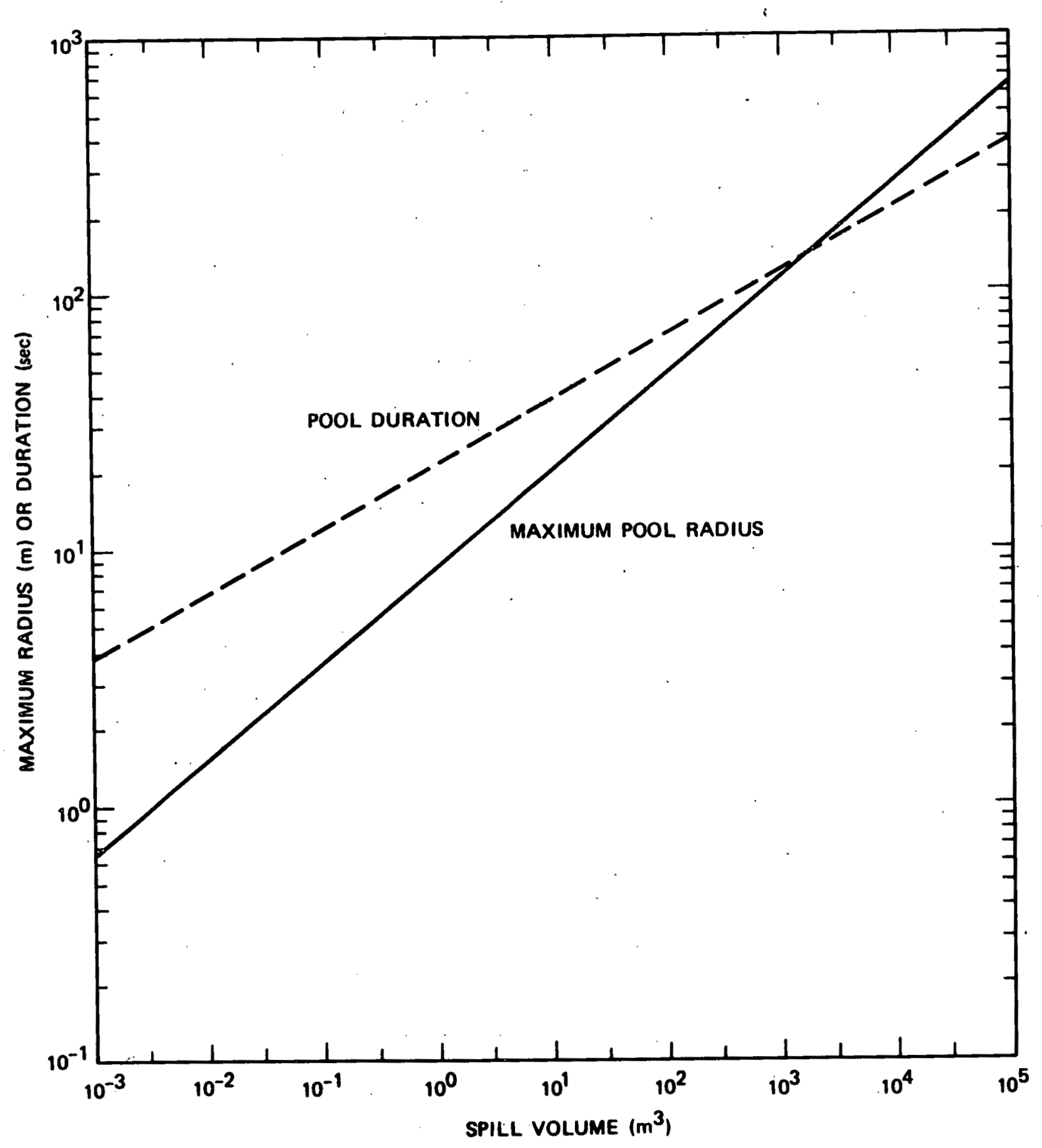

Figure 5-5: Maximum LNG pool radius and duration for an instantaneous spill on water, according to the theory of Raj and Kalelkar (Ref. 5-6), assuming a constant boiloff rate of $0.042 \mathrm{~cm} / \mathrm{s}$ 
boiloff rate are within 2 percent of that of the corresponding "instantaneous" spill, and the total lifetime (which is of less practical significance) is within 15 percent. Hence, any spill of $0.5 \mathrm{~m}^{3}$ within $8 \mathrm{~s}$ or $25,000 \mathrm{~m}^{3}$ within $130 \mathrm{~s}$ is effectively instantaneous. A typical $25,000-\mathrm{m}^{3}$ ship tank $20 \mathrm{~m}$ high would spill in $130 \mathrm{~s}$ if it had a puncture of about $30-\mathrm{m}^{2}$ area near its bottom, which is not inconceivable if. another large ship should strike it.

The fraction of ethane and propane in the LNG certainly influences differential boiloff, at least in determining the fraction of these hydrocarbons in the vapor clouds, if the cloud is well mixed, or the size of the ethane and propane clouds, if they are well-separated. Moreover, it is possible that the composition affects the total boiloff rate in these unconfined water spills, as it does in confined water spills, (Ref. 5-9). Accordingly, in the recommended research program a particular LNG composition of 10 to 15 percent ethane and 2 to 5 percent propane should be chosen, and these concentrations held fixed within \pm 10 percent for all of the tests. This might require purchase of gas cylinders of commercialgrade methane, ethane and propane, and condensing the methane with liquid nitrogen, and the ethane and propane by bubbling it through the LNG.

The first eight tests listed in Table 5-1 involve simple unconfined spills from two different heights, with and without waves (other than the waves generated by the spill itself), and with and without a deflecting disk under the water at the spill point. The lower height requires placing the spill tank just above the water to simulate better a spill from a ship tank; the higher height is comparable to those used in past spill tests. Results using the deflecting disk would indicate the possible effects of the disk used on the China Lake tests, or of a shallow channel bottom in a 
full-scale spill. Accordingly, it is recommended that the disk be placed at a scaled depth slightly greater than the draught of a tanker, i.e., $15 \mathrm{~m} \cdot(0.5 / 25,000)^{1 / 3}=0.4 \mathrm{~m}$. The disk should be transparent to permit photography of the spill point from below.

In the next four tests the LNG would be spilled at the point of intersection of a ship model colliding broadside with an LNG tanker model. Since a typical tanker is about $280 \times 40 \times 28 \mathrm{~m}$, scaling down by a factor of $(0.5 / 25,000)^{1 / 3}=$ $1 / 37$ gives model dimensions of $7.6 \times 1.1 \times 0.8 \mathrm{~m}$. According to theory (see Figure 5-5), neglecting the effects of the ships, the maximum LNG pool diameter will be $13 \mathrm{~m}$, or 1.7 times the ship length, while in the full-scale case the LNG pool diameter would be 2.7 times the ship length. This difference occurs because the boiloff rate cannot be scaled, as discussed earlier. The maximum diameter could be properly scaled in relation to the ship by using a ship scale factor of $(0.5 / 25,000)^{3 / 8}=1 / 58$, but then much of the spreading period, before boiloff became dominant, would be less accurately modeled. Some additional thought and analysis is required before making a decision between $1 / 58$ scaling, 1/37 scaling, or an intermediate value. Whichever choice is made, the detailed data at early times can be scaled in one way, and those at later times in the other. (The situation is somewhat similar to wind-tunnel testing of aircraft models, where the pressure drag and skin-friction drag scale differently with size, but can be determined separately and combined appropriately.)

The following four tests would be somewhat more realistic ship-collision simulations, because the ING would be poured temporarily into a scaled-down tank in the LNG ship model, and then a wedge valve in the side of this tank would be partially opened to simulate a hole produced by a 
collision, with the wedge representing the bow of the colliding ship. In this way the LNG would enter the water with a realistic horizontal velocity component and a minimum vertical velocity. Rough arguments connected with the resisting force of the water suggest that this horizontal velocity will have little effect on the later pool growth and boiloff, but experimental verification is desirable. (A simpler method of giving the LNG horizontal velocity would be to pour it into a chute with a horizontal exit, but this would yield unrealistically high horizontal velocities.) If part of the wedge valve were actually underwater, useful information could also be obtained on how the water displaces the LNG in such a tank rupture.

The last two tests specified in detail are for sim-, ulating the spill of $25 \mathrm{~m}^{3}$ of LNG in $30 \mathrm{~s}$ from a broken transfer line next to a ship at deck height (about $16 \mathrm{~m}$ ). At the corresponding linear scale of $(0.5 / 25)^{1 / 3}=1 / 3.7$, the spill height should be $4.3 \mathrm{~m}$, the water depth should be $4 \mathrm{~m}$ or deeper (so the deflector should not be used), and the ship hull should be much longer than the maximum LNG pool diameter, so it can be simulated by a long board partially submerged in the water.

All of these tests would be performed both with and without water waves, other than the waves produced by the spill itself, since it is believed this can be done rapidly and inexpensively by switching on or off a mechanical wave generator, without changing the experimental setup. The typical larger waves expected to be encountered by an LNG tanker near a populated area are around $1 \mathrm{~m}$ in height, since in storms the tanker would stand out to sea. Accordingly, it is recommended that the wave heights employed in the tests be scaled from $1 \mathrm{~m}$, which gives waves $2 \mathrm{~cm}$ high for the fulltank spill simulations and $20 \mathrm{~cm}$ high for the line-break simulations. Past tests suggest that rough water decreases the 
boiloff rate, so such a condition is expected to prove less important from a safety standpoint, and some of these tests might be omitted or performed using natural waves during windy weather (without trying to get a particular wave height).

At the end of the test series ten contingency tests are provided. These permit duplication of those earlier tests that seem most important, or that gave unexpected results or experienced instrument failures. They also permit further exploration of the effects of varying those parameters shown to be most significant by the earlier tests.

The recommended instrumentation for the swimming-pool tests is shown in Figure 5-6. The instruments include four underwater movie cameras looking up from the bottom and one camera looking down from a central tower, to observe the spreading of the LNG over the water and its eventual disappearance by vaporization. The underwater cameras are needed because clouds of condensed moisture may obscure much of the view of the overhead camera. Their number might be decreased by employing a deeper swimming pool, like the one at Sandia Base, to permit each of them to view a larger fraction of the pool. Speeds of around 24 frames/second are adequate for these cameras. Three additional movie cameras with speeds around 64 frames/second should be placed in half-submerged boxes at the water surface. These boxes would have horizontal windows parallel to the spreading velocity of the LNG, to observe selected cross sections of the LNG layer on the water surface. Thus, not only the position of the LNG front would be photographed, but also the height of the LNG layers at later times, and some of the dynamics of the boiling, water waves and possible ice formation: If feasible, a dye should be added to the LNG to improve its visibility.

Sets of thermocouples, fixed or mounted on floats, should also be deployed to sense the LNG spreading and water cooling, 


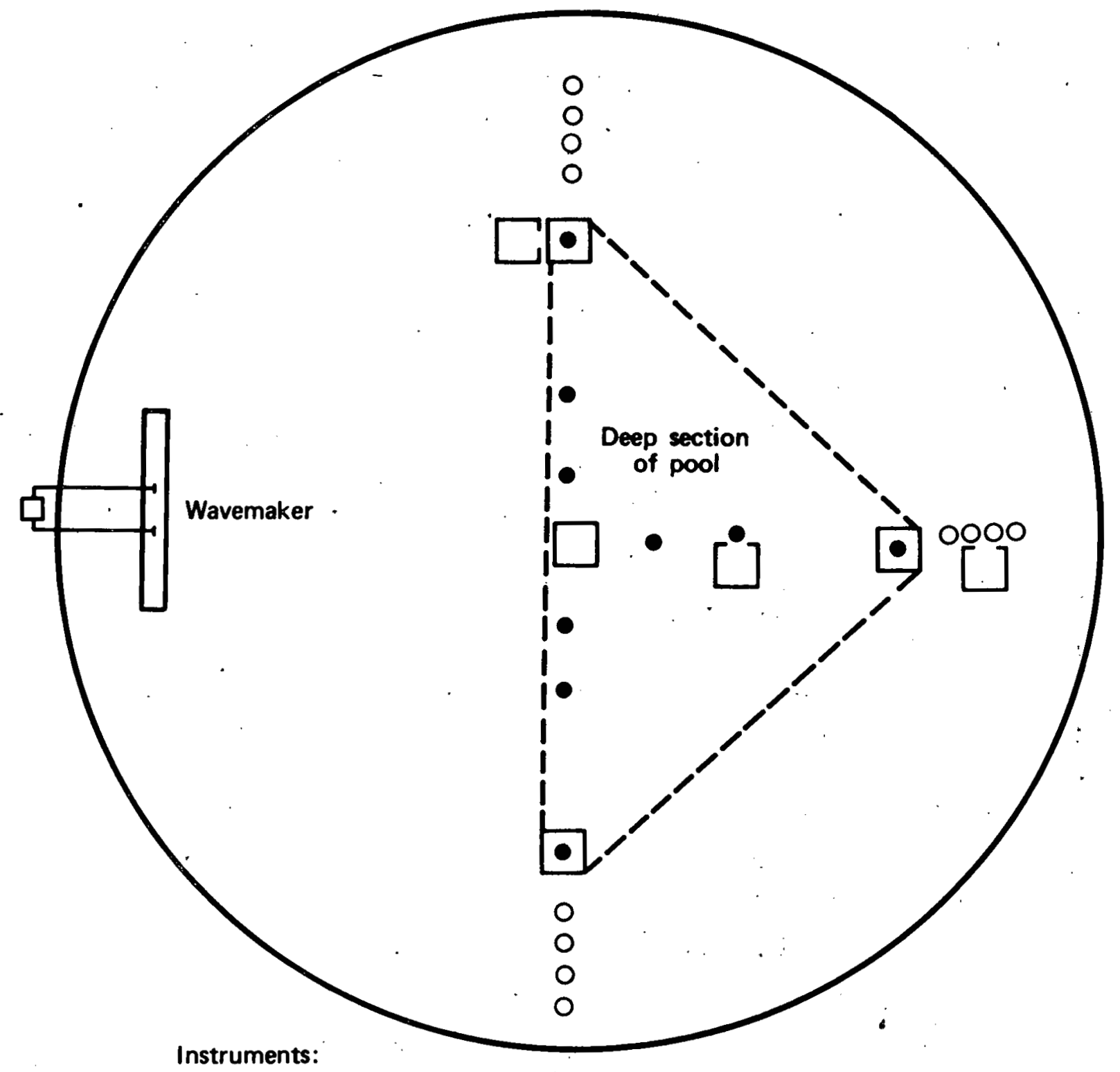

4 underwater 16-mm movie cameras, approx. 24 frames/second

3 surface 16-mm movie cameras, approx. 64 frames/second

- 9 rakes of 8 thermocouples each, on floats constrained not to move horizontally

- 12 rakes of 3 thermocouples each, on similar floats

Not shown:

12 vapor grab bottles, remotely activated

3 infrared vapor-concentration sensors (if available)

Figure 5-6. Instrumentation arrangement for the swimming pool tests (top view). 
as a backup to the cameras on these tests and to develop and check instrumentation for the larger field tests, where the relatively shallower depths and probably less clear water will prevent adequate underwater camera coverage. Nine vertical rakes of eight thermocouples each should be positioned at various points on the water, as indicated in the figure, to determine not only the time of arrival of the LNG front, but also the subsequent variation of ING height with time at each position. In order to sense the later decrease of the liquid height in the presence of equally cold vapor, either some electric heating of the thermocouples would be provided, or a warm gas jet would be directed at them with sufficient force to shield them from the LNG vapor without disturbing the liquid. At points near the expected maximum diameter of the LNG pool, where the depth would be too small to measure by such a system (especially since mounting on floats cannot completely compensate for high-frequency wave motions of the water), rakes of three thermocouples are recommended for determining only the time of the front arrival. It is believed: that, by proper choice of the thermocouple size, their response to a possible cold vapor front ahead of the liquid will be sufficiently slow to permit detection of the liquid front.

In addition, it is recommended that a few devices be constructed that would measure the amount of ice formed during the ING boiloff at several times and places. A possible design for such a device consists of a perforated flat plate with teeth around the edge, which is quickly raised from below the water surface, to weigh the ice over this area by measuring the lifting force, as well as to-determine whether the ice formed a solid sheet by detecting any extra breaking force. Since a heat balance calculation indicates that less than $1 / 2 \mathrm{~cm}$ of ice could be formed in these tests, a plate $30 \mathrm{~cm}$ across should be sufficient to minimize errors due to 
irregular breaking of the ice. This device should be designed to make two or three measurements at successive times, if a preliminary analysis shows that it is feasible to resubmerge the plate, move it horizontally a few diameters to undisturbed ice and raise it for another weighing, within the approximately $20 \mathrm{~s}$ of boiloff time, without producing water currents strong enough to disturb the ice formation. Four such devices would be deployed at different distances from the spill point, three of them at the same distances as the three surface cameras.

The remaining instruments would be employed for measuring the extent of differential boiloff. Sets of three remotely activated sampling bottles, similar to those used in tests at China lake (Ref. 5-10), would be stationed at four different positions just high enough above the water to prevent ingestion of liquid. At each point the three bottles would be opened at different times to determine the time variation of differential boiloff. In addition, since infrared absorption instruments for continuous measurement of hydrocarbon vapor concentrations are currently being developed for vapordispersion tests (Ref. 5-14), two or three of these instruments should be deployed adjacent to some of the sample bottles. Data from these sensors, and from the thermocouples described above, should be recorded on magnetic tape for later analysis.

It is tempting to add some measurements of downwind vapor dispersion to these swimming pool tests. However, the value of such measurements for predicting the vapor dispersion from a $25,000-\mathrm{m}^{3}$ spill is considerably limited by the scaling laws for meteorological parameters, which require a wind velocity varying as the one-sixth power of the wind speed, and a vertical atmospheric temperature gradient varying as the inverse cube root (see section VI). Since it is virtually 
impossible to find steady winds less than $1 \mathrm{~m} / \mathrm{s}$ the swimming pool tests can only simulate full-scale winds greater than about $6 \mathrm{~m} / \mathrm{s}$, and very small atmospheric temperature gradients. Moreover, the inability to scale the specific boiloff rate, as discussed earlier, makes the simulation only approximate. Finally, for useful vapor dispersion tests one must insure that structures around the spill, such as the spill tank and the swimming pool wall, do not seriously affect the vapor dispersion, and in testing one must wait for the desired wind velocity and direction. Because of all of these difficulties, vapor dispersion measurements on the swimming pool tests do not appear to be justified.

The swimming pool installation and instrumentation recommended in this section for investigating LNG spreading and boiloff could be applied equally well to an investigation of LPG spreading and boiloff.

d. Field tests--A number of relatively large LNG spill tests are recommended in sections VI to IX to provide essential data on vapor dispersion, flame radiation and potential explosion. Generally, the LNG will be dumped rapidly from a tank supported a short distance above the surface. The tests include unconfined spills of up to $350 \mathrm{~m}^{3}$ on water, and land spills on dike floors up to $25 \times 30 \mathrm{~m}$. At least one test of each configuration will be ignited to produce a pool fire.

The largest test spill size, $350 \mathrm{~m}^{3}$, is chosen because this size is large enough to permit simulating the vapor dispersion from a $25,000-\mathrm{m}^{3}$ spill on water by properly scaling the wind speed and atmospheric temperature gradient (see section VI), while somewhat larger tests $\left(1000 \mathrm{~m}^{3}\right.$ or so) provide little simulation advantage, but the costs of the storage tank and the LNG would become very large. From Figure 5-5, these tests-will require-a-body of water at least $200 \mathrm{~m}$ in diameter. Most of the water can be quite shallow, but to 
prevent bottom surface interactions near the spill point the water depth in this vicinity should be at least equal to the height of the top of the spill tank, i.e., about $10 \mathrm{~m}$, unless the swimming pool experiments with the underwater disk show that such effects are unimportant.

The accidental land spill of greatest concern with respect to public safety is the conceivable rapid spill of the entire contents of a storage tank into a surrounding broad, low dike. This would cover the entire dike floor with LNG, even if the floor were sloped or had sumps to minimize the boiloff from smaller spills. Such a large spill can be adequately simulated in a scaled-down dike around $25 \times 30 \mathrm{~m}$ in size. By making the floor of the scaled-down dike level, only about $100 \mathrm{~m}^{3}$ of LNG are required for a test, since this is adequate to give a liquid depth of about $15 \mathrm{~cm}$ and hence to simulate the first few minutes of most rapid boiloff that is of greatest safety concern. For accurate simulation of the vapor flow over the dike walls, the model dike floor should be raised so that the top surface of the LNG reaches a height corresponding to that for a full-scale complete tank spill.

Before the land tests are performed, the boiloff rates of LNG on the soils and insulating materials to be used should be measured on small samples in an apparatus like that used in previous measurements at M.I.T. (Ref. 5-2). If necessary, the soil'surface should be treated or replaced, and the insulation modified, to obtain the desired boiloff rates (which should be scaled down by a factor of around 2 below the full-scale dike values of interest).

The detailed parameters of the various field tests are listed and explained in later sections, so they will not be discussed further here. However, in every field test it is important to make reasonably accurate measurements of the LNG 
spreading and boiloff history, in order to characterize the test properly. The resulting extensive set of data, together with the swimming pool measurements described earlier, should be more than sufficient to develop reliable semiempirical relations for predicting the spreading and boiloff of large accidental spills.

The fraction of ethane and propane in the LNG used in the field tests should be the same (within \pm 10 percent) as that used in the swimming pool tests, as discussed earlier. The spreading and boiloff instrumentation for the water spills should also be essentially the same, with the omission of the underwater cameras and the raising of the overhead camera to a correspondingly higher point, using a tall tower, tethered balloon or aircraft. On the land spills in dikes, the LNG level should be measured by using several float gages and manometer gages, similar to those used in the AGA Phase II tests (Ref. 5-15), but with refinements to overcome the gagesticking problems previously encountered. (These refinements would include use of noncorrosive materials, and bubbling of dry nitrogen through the manometer tube to prevent plugging.) In addition, the possible use of a nuclear liquid-level gage should be investigated. (One was tried unsuccessfully in the Phase II tests.) In parallel fashion to the water test instrumentation, a few vertical rakes of thermocouples, cameras half-buried in the dike floor, sampling bottles and infrared analysers should also be deployed. On land and water tests that are to be ignited, much of this instrumentation might be omitted, depending upon the tradeoff between the potential value of the data and the possible damage to the instruments.

The LNG field-test installations and instruments described above could be applied equally well to field tests of IPG spills. 
e. Extended effort--The swimming pool and large field tests described above are considered important for solving the highest priority LNG safety problems. If a longer range program is desired to provide higher confidence and accuracy, and answer questions of moderate priority, some further spill tests should be added. These would include repetition of many of the swimming-pool tests, and addition of tests that vary the spill rate and other parameters, to simulate various conceivable accidents. Moreover, in the following sections of this report some supplemental large field tests are suggested as part of the extended efforts to improve our knowledge of vapor dispersion and combustion; on these tests LNG spreading and boiloff measurements should be made to provide additional data.

\section{MATHEMATICAL MODELING}

a. Basic effort--It is recommended that three relatively simple mathematical modeling tasks be undertaken. The input data for these models would be obtained initially from the swimming pool tests. When similar data from the large field tests become available, these inputs would be modified if necessary, and the models revised accordingly.

The first task would be simply to use the LNG spreading data to verify or modify the relation of Raj and Kalelkar (Ref. 5-6) for the LNG pool radius versus time, and to derive an empirical correction for the case of spreading around the end of a ship. The remaining two tasks would employ the experimental data on the boiloff rate and LNG front velocity as a function of LNG height and possibly other parameters to obtain boundary conditions for improving two types of spreading analyses. The first analysis would use the global approach of Raj and Kalelkar (Ref. 5-6), which yields an ordinary differential equation for the pool radius versus time that would 
be integrated analytically or numerically. The second analysis would use shallow-water theory, leading to a one-dimensional numerical calculation of the LNG height as a function of radius and time. Both approaches would be applied to all of the circular or semicircular test cases, and the results compared with the measurements. After appropriate adjustments, they would then be used to calculate the behavior of full-scale spills.

The results of these two analyses might also be applied to the spreading of LPG on water, by correcting for the difference in density and boiloff rate between LNG and LPG. Also, if data are taken on swimming pool or field tests of LPG, they could be applied directly to such analyses.

b. Extended effort--To cover a greater variety of spill conditions, we recommend that the two analyses described above be applied to situations involving a variety of spill rates. In addition, a two-dimensional shallow-water model would be develeped and applied to the spreading of LNG around the end of a ship, between ship and shore, etc.

To provide a better basic understanding of the spreading - and boiloff process, we also suggest that a more detailed and complex model be developed. This would involve two-: dimensional calculations of the radial and vertical flow fields of unconfined spills using appropriate turbulence and boiling heat-transfer models. Such an approach would probably require more than three years to give results of practical utility. 


\section{REFERENCES FOR SECTION V}

5-1. Dressler, R. F., "Hydraulic Resistance Effect Upon the Dam-Break Functions," J. Res. N.B.S., Vol. 49, 1952, Pp. 217-225.

5-2. Reid, R. C., and Wang. R., "The Boiling Rates of LNG on Typical Dike Floor Materials," Cryogenics, July 1978, pp. 410-414.

5-3. Burgess, D. S., Murphy, J. N., and Zabetakis, M. G., Hazards of LNG Spillage in Marine Transportation, U.S. Bureau of Mines, SRC Report No. S-4105, 1970 (AD 705078).

5-4. Boyle, G. J., and Kneebone, A.; Laboratory Investigations into the Characteristics of LNG Spills on Water. Evaporation, Spreading and Vapour Dispersion, Shell Research Ltd. (U.K.), A.P.I. Project on LNG Spills on water (Ref. 6z32), March 1973.

5-5. Feldbauer, 'G. F., Heigl, J. J., McQueen, W., Whipp, R. H., and May, W. G., Spills of LNG on Water - Vaporization and Downward Drift of Combustible Mixtures, Esso Research \& Engineering Co., Report No. EE61E-72, 1972.

5-6. Raj, P.P.K., Kaleikar, A. S., "Fire-Hazard Presented by a Spreading, Burning Pool of Liquefiel Natural Gas on Water," presented at Western states Section of the Combustion Combustion Institute, 1973 Fall Meeting, Paper \#73-25.

5-7. Hoult, D. P., "Oil spreading on the Sea," Ann. Rev. - Fluid Mech., Vol. 4, 1972, pp. 341-368.

5-8. Raj, P.P.K., et al., Experiments Involving Pool and Vapor Fires from Spills of Liquefied Natural Gas on Water, A. D. Little, Inc., Report \#82404, March 1979 .

5-9. Valencia-Chavez, J. A., and Reid, R. C., "The Effect of Composition on the Boiling Rates of Liquefied Natural Gas for Confined spills on Water," Int. J. Heat Mass Transfer, Vol. 22, 1979, pp. 831-838.

5-10. Stein, W., "The Spreading and Differential Boil-off for a spill of Liquefied Natural Gas on a Water Surface.," Report A of Liquefied Gaseous Fuels Safety and Environmental Control Assessment Program: A Status Report, U.S. Dept. of Energy, DOE/EV-0036, May 1979. 
5-11: Lind, C. D., and Whitson, J. C., "China Lake Spill'Tests," Report I of Liquefied Gaseous Fuels Safety and Environmental Control Assessment Program: A Status Report, U.s. Dept. of Energy, DOE/EV-0036, May 1979.

5-12. Reid, R. C., Smith, K. A., and Chang, H., "Simultaneous Boiling and Spreading of Liquefied Petroleum Gas (LPG) on Water, Report $S$ of Liquefied Gaseous Fuels Safety and Environmental Control Assessment Program: A Status Report, U.S. Dept. of Energy, DOE/EV-0036, May 1979.

5-13. Drake, E. M., Jeje, A. A., and Reid, R. C., "Transient Boiling of Liquefied Cryogens on a Water Surface," Int. J. Heat Mass Transfer, Vol. 18, 1975, pp. 1361-1368,

5-14. Koopman, R. P., et al., "A Review of the 1978 China Lake LNG Dispersion Experiments and Instrumentation," Report $K$ of Liquified Gaseous Fuels Safety and Environmental Control Assessment Program: A Status Report, U.S. Dept. of Energy, DOE/EV-0036, May 1979.

5-15. LNG Safety Program, Interim Report on Phase II Work, AGA Project IS-3-1, Battelle Columbus Laboratories, , July 1,1974 . 
VI. RECOMMENDED RESEARCH ON LNG VAPOR CLOUD DISPERSION

\section{INTRODUCTION}

One of the greatest technical needs in assessing the public safety of LNG operations is a high-confidence spatial and temporal description of the unignited vapor cloud from a large LNG spill, for use in defining the extent of the vapor cloud combustion and explosion hazards. Spreading and dilution of the LNG vapor cloud occur by turbulent processes, and turbulent concentration fluctuations can produce local patches of flammable mixture even at points where the mean fuel/air $\mathrm{mix}-$ ture ratio is outside the flammable range. Accordingly, reliable characterizations are needed of both the mean and the fluctuating gas concentrations throughout the vapor cloud at various times following the spill. One also needs an accurate description of any significant separation, layering, or pocketing of the ethane and propane vapor relative to that of methane. These descriptions are needed for a sufficient range of weather and terrain conditions (including man-made structures) to cover all major LNG sites.

In the United States, a relatively large number of moderate-size ING field experiments have been carried out -in dikes on land with spills of up to about $35 \mathrm{~m}^{3}$ of LNG (Ref. 6-1), and on water with spills of up to about $6 \mathrm{~m}^{3}$ (Ref. 6-2). Although the instrumentation on these tests was limited in accuracy and coverage, the data have been useful for describing the general behavior of LNG spills. However, they have not provided the information needed for scaling to largesize spills with good accuracy and confidence. Wind tunnel experiments have also been used to simulate full-scale land spills in dikes (Refs. 6-3,6-4). The wind tunnel simulation spills in dikes have had some (but not a sufficiently broad) 
confirmation by a field test in a 24-m-diameter dike. Wind tunnel simulations of large spills on water have not been reported.

In addition, considerable mathematical modeling has been performed to describe the mean concentrations in such clouds. Among the most credible of these models are the relatively simple analytical model of Germeles and Drake (Ref. 6-5), the more complex model of Cremer and Warner analysts (Ref. 6-6), and the three-dimensional (3-D) Eulerian hydrocode SIGMET developed by workers at Science Applications, Inc. (Refs. 6-7, 6-8). Predictions by two of these models, and by wind tunnel tests, for the maximum distance to the lower a flammability limit ( $L F L$ ), corresponding to 5 percent methane by volume (neglecting turbulent fluctuations), are shown in Figure 6-1, for spills on water in a $2.2 \mathrm{~m} / \mathrm{s}$ wind. Results from the Cremer and Warner model are not shown because they are not available for this wind speed, but at $4.5 \mathrm{~m} / \mathrm{s}$ they lie between the results for the other two mathematical models (Ref. 6-9). For small spill volumes, which have little gravity-spreading effects except for very low wind speeds, the mathematical models agree quite well. However, at larger spill volumes, the LFL predictions vary considerably. At a spill volume of $25,000 \mathrm{~m}^{3}$ and neutral atmospheric stability (Pasquill Class D), the predicted maximum LFL distances vary from 2.6 to $5.3 \mathrm{~km}$, about a factor of 2 (Ref. 6-8). For stable atmospheric conditions (Class F) where atmospheric mixing is greatly inhibited, the Germeles-Drake model predicts a much larger distance, $18.5 \mathrm{~km}$ (Ref.6-10). No SIGMET results for this case are available, but SIGMET results for a somewhat larger spill $\left(88,000 \mathrm{~m}^{3}\right)$ and slightly higher wind speed $(3 \mathrm{~m} / \mathrm{s})$ show only about a 10 percent increase in going from a class $D$ to a Class $G$ (very stable) atmosphere (Ref. 6-7). Accordingly, one expects that the SIGMET model 


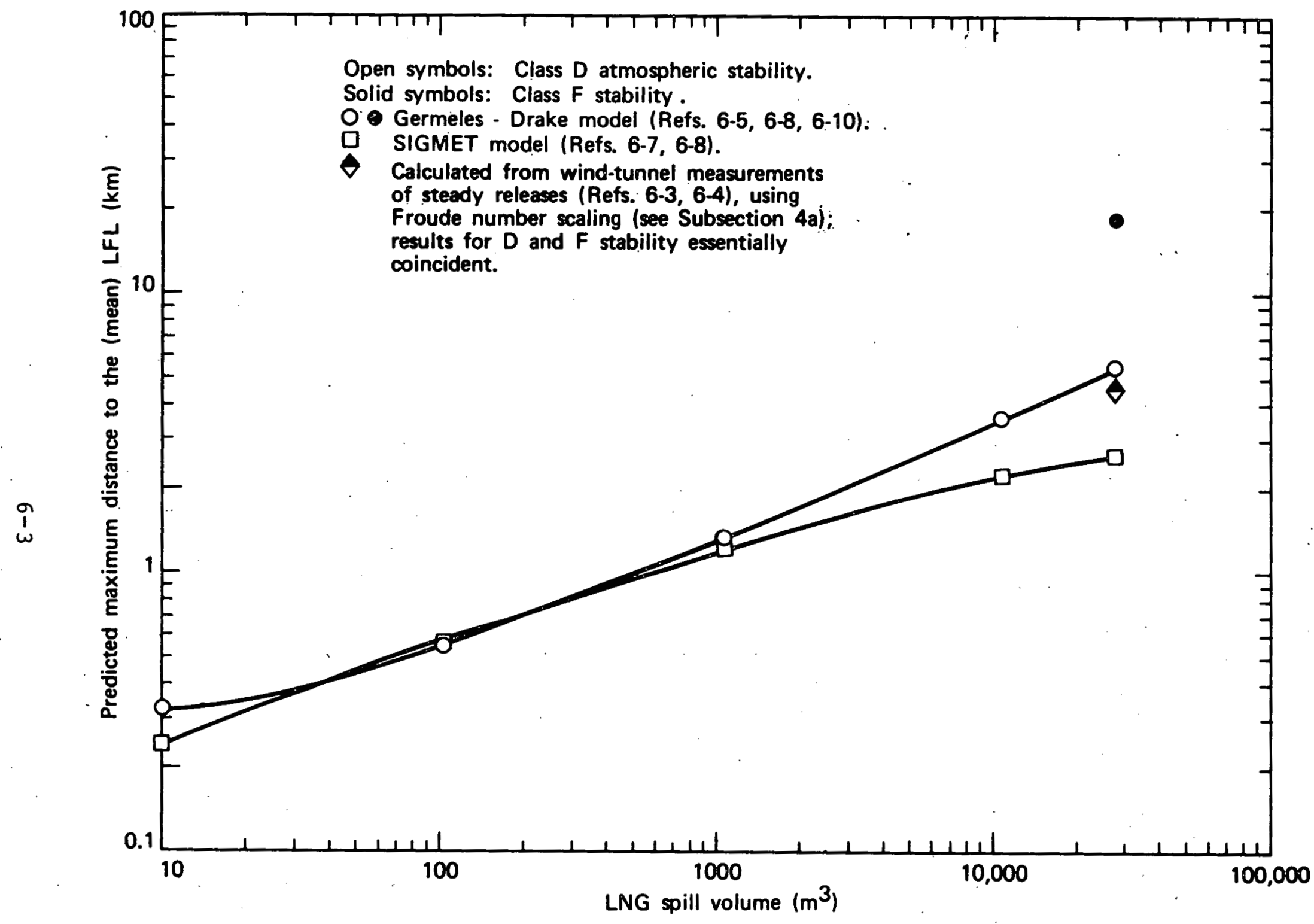

Figure 6-1. Maximum distance to the LFL (5 percent mean vapor concentration) predicted by two analytical models and by scaling wind tunnel results, for instantaneous spills of LNG on water in a $2.2 \mathrm{~m} / \mathrm{s}$ wind. 
would give a maximum LFL distance of about $3 \mathrm{~km}$ for a $25,000-\mathrm{m}^{3}$ spill in class $\mathrm{F}$ conditions, which is only $1 / 6 \mathrm{th}$ of the distance given by the Germeles-Drake model. This uncertainty of a factor of 2 to 6 has serious practical consequences, especially for LNG facilities sited in or near cities where large exclusion distances may be infeasible or costly.

Moreover, no adequate theory exists for the turbulent concentration fluctuations in the cloud, or for the distribution of the ethane and propane vapor within it. In safety evaluations the strength of the turbulent fluctuations is often expressed in terms of a "peak-to-mean ratio," which is generally taken to have a value of around 2 or 3 (Ref. 6-5), based roughly on past LNG field tests. However, using some of the field data, Fay and Lewis (Ref. 6-11) deduced a statistical distribution of peak-to-mean ratios, with a value exceeding 4 a few percent of the time. On the other hand, the data were scattered and the fit approximate, and it is not known whether the same values would apply to a much larger spill. Moreover, little is known about whether the concentration peaks represent small discrete patches that would give only brief flashes if ignited, or long streaks of flammable mixtures, such as the "structures" observed in many turbulent flows (Ref, 6-12), which could result in much larger fires. *

Because of the current uncertainties in both the mean concentrations and the turbulent fluctuations, we believe that further research on the dispersion of large LNG vapor clouds is clearly necessary.

*Apparently the only relevant published information is that on an LNG test spill in a 5-ft-diameter earthen dike, where flares $100 \mathrm{ft}$ downwind caused only local ignition, without propagation back to the dike (Ref. 6-13). 
It is desirable to set quantitative goals for this research that both satisfy practical needs and have a reasonable chance of being attained. For LNG facilities in areas where land is particularly expensive, there is a strong incentive to minimize the distance out to which other activities must be excluded. Accordingly, an accuracy goal of around \pm 10 percent in the predicted LFL distance from a diked spill or a linebreak spill near a dock would clearly be advantageous. However, it is doubtful that this degree of accuracy is attainable in a limited-duration research program. The AGA field test data for diked spills (Ref. 6-1) show a scatter of about \pm 25 percent in the distance to the mean LFL (averaged over the turbulent concentration fluctuations). The wind tunnel data scatter less for a given configuration, although the data are scant (Refs. 6-3, 6-4). A new test program with improved instrumentation should be able to do somewhat better, although the accuracy may be limited by the inherent nonuniformity and short-period variability of the air flow near the ground.

Accordingly, we propose as optimistic research goals the development of techniques that permit the determination of the distance to a given mean LNG vapor concentration for a specified LNG site, spill and weather, with an uncertainty of \pm 15 percent (or a factor of 1.3 from the lowest to the highest prediction), and the application of these techniques to yield numerical results for a few specific situations of highest practical importance. (Other situations could then be treated rapidly, but with some loss in accuracy, by interpolation or extrapolation of these results, or with better accuracy by application of the same research techniques.) It should be pointed out 
that these accuracy goals are not as stringent as they might seem, since a \pm 15 percent uncertainty in the distance to a given concentration corresponds to about a \pm 30 percent uncertainty in the concentration at a given distance.

In addition to these goals concerning the mean concentration (averaged over the turbulent fluctuations), additional goals would be to obtain techniques and results for the peakto-mean ratio and the heavier hydrocarbon concentrations, in the same specific situations, with an accuracy of \pm 25 percent, together with a semiquantitative understanding of the geometry of the turbulent fluctuations. These goals must be set because of the need to characterize the spatial variations in the cloud that can affect flame propagation and possible explosion (see Sections VIII and IX). The accuracy of these goals is set lower than that of the mean-concentration goals because of their greater difficulty and somewhat less practical importance.

We believe that all of the above goals are both responsive to industry needs and have a fair chance of being achieved, although we cannot be sure about the latter until the program nears completion.

In the remainder of this section we discuss the key physical mechanisms affecting cloud dispersion and a technical approach to research designed to attain the goals specified above.

2. GENERAL FEATURES OF LNG VAPOR DISPERSION

Consider first the case of a large LNG spill (thousands of cubic meters) in a land facility--typically a 30-m-diameter tank surrounded by a low rectangular dike about $100 \mathrm{~m}$ on a 
side. Prior to the spill, wind interactions with the tank and dike set up a shear region which propagates downwind. Horseshoe vortices are shed from the tank, and vortex sheets are shed from the dike. These are embedded in the atmospheric boundary layer--a shear layer with vertical gradients in velocity and temperature. This complex flow field forms the initial conditions for the problem. Next assume a tank rupture which rapidly spills the LNG into the diked area. Heat transfer from the dike floor and walls vaporizes the ING at a rate which decreases with time as the solid surface cools. The vapor cloud is initially about 40 percent more dense than air, which causes it to spread laterally due to gravity. This is demonstrated in Figure 6-2 which shows the LNG vapor spreading, simulated in wind tunnel tests performed at colorado state University (Refs. 6-3, 6-4). The initial cloud movement is greatly influenced by gravity spreading for wind speeds up to tens of meters per second. In addition, the vortex wakes of the tank and dike entrain vapor and may have a significant effect on the downwind vapor distribution. Recent wind tunnel tests of cloud dispersion from rectangular dikes indicate that the vapor can be captured in the vortices from the dike, resulting in a bimodal concentration across the cloud width as shown in Figure 6-3 (Ref. 6-3). Sharp terrain contours may have a similar effect.

The relative motion between the air and the LNG vapor creates a shear layer that causes turbulent mixing, even for the case of zero ambient wind velocity. Initially the large density differences have a strongly stabilizing effect on the shear layer. For example, the cloud starts out with a Richardson number of about 200. and, as shown in Figure 6-4 (Ref. 6-14), the entrainment velocity is reduced by two to three orders of magnitude compared to the entrainment velocity expected for a uniform density fluid. Near the LFI the 


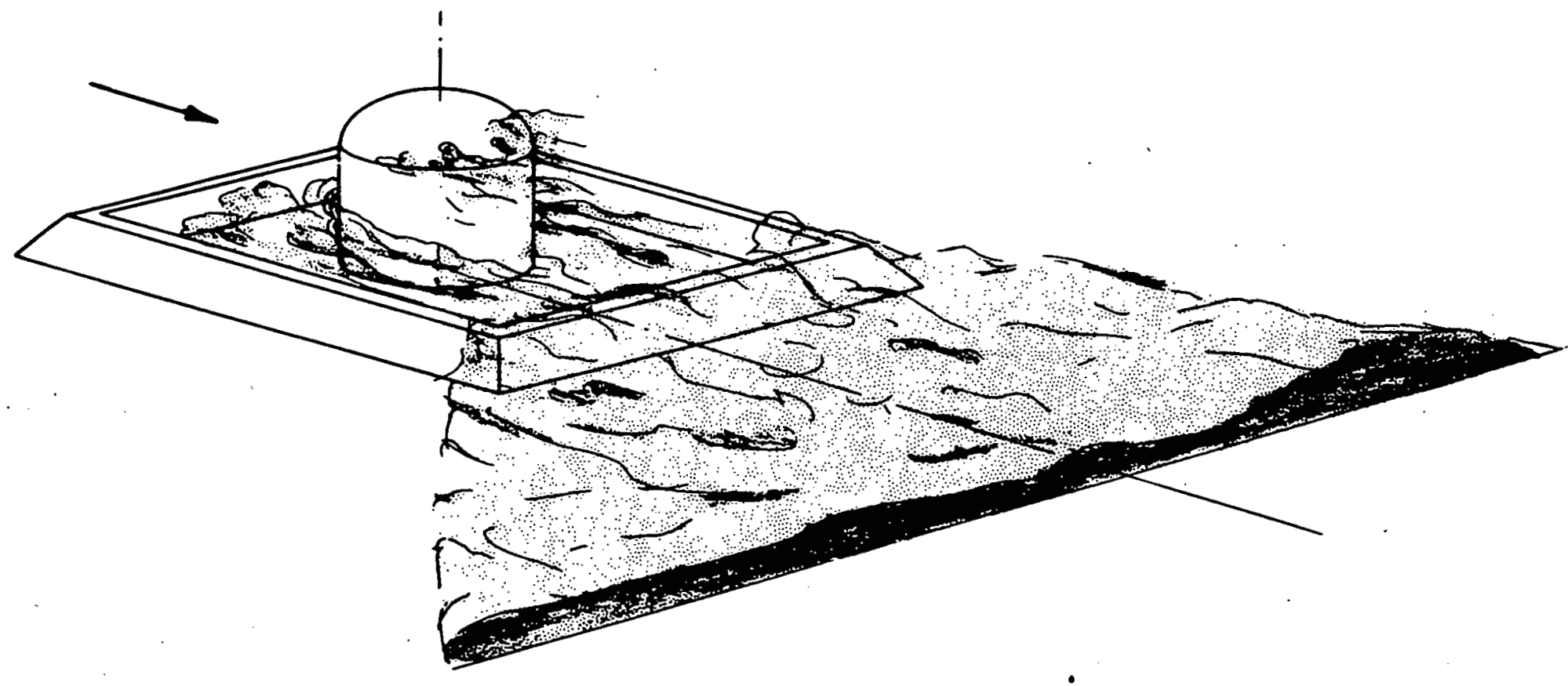

Figure 6-2. Visualization of the plume from the low dike model in a wind tunnel simulation test. (Ref. 6-3, 6-4) 


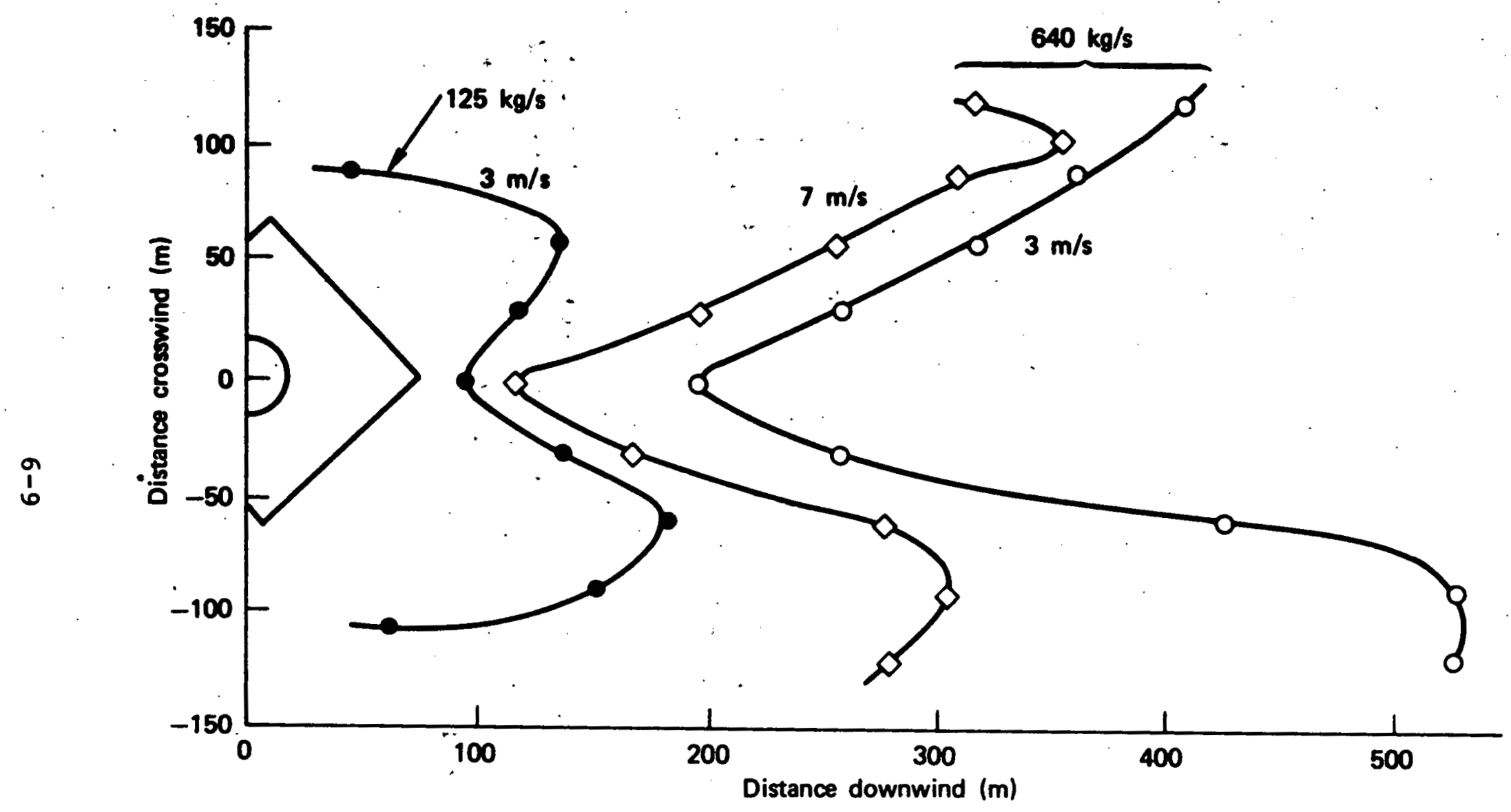

Figure 6-3. Wind tunnel contours of 5 percent helium-nitrogen (corresponding to 5 percent methane) at the ground level for a low dike at 45degree orientation (indicated on the left of the figure) in a neutral atmosphere (Ref, 6-4). The coordinates and curves are labeled with the full-scale distances, vapor release rates, and wind speeds. 


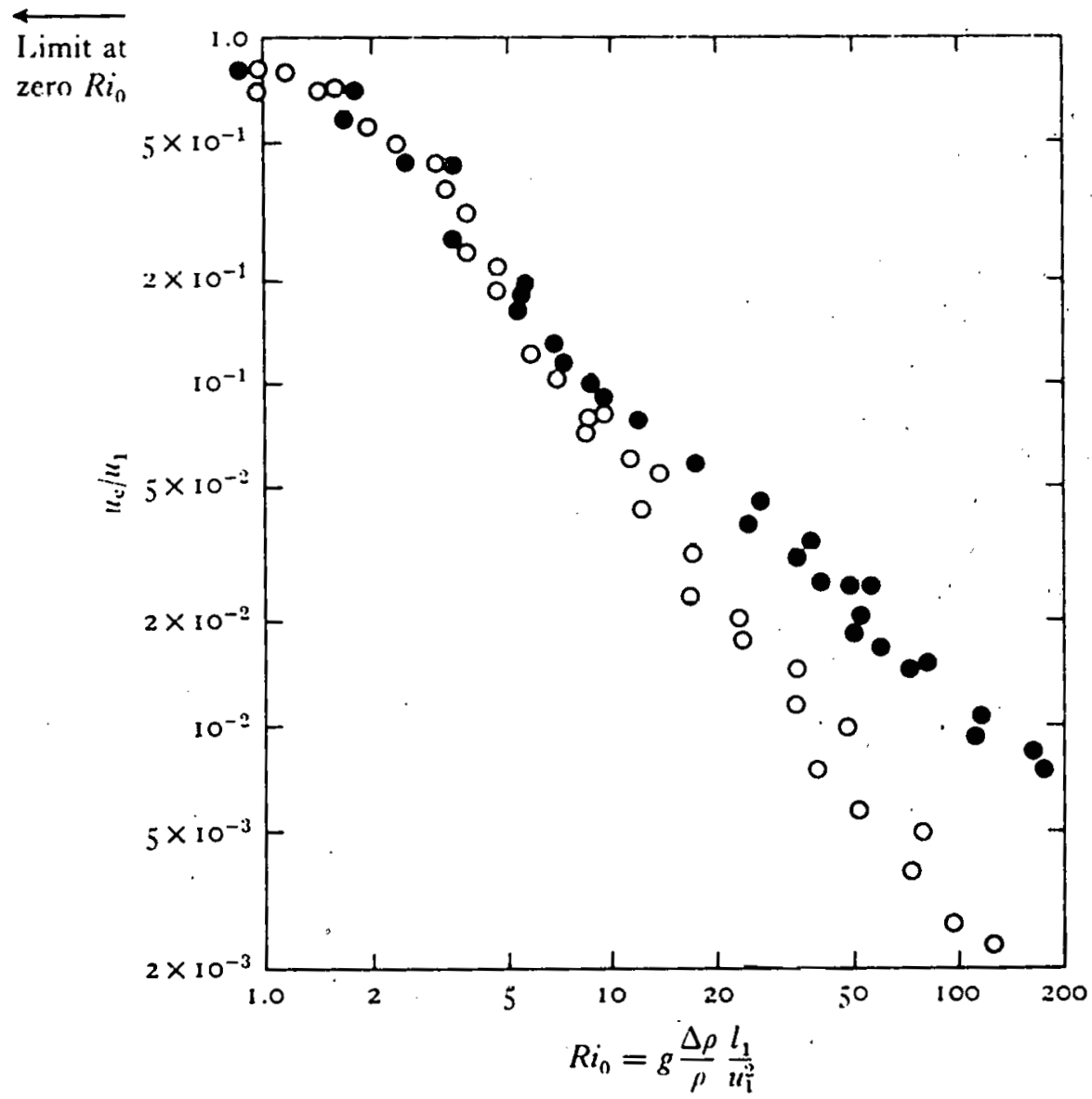

Figure 6-4. A comparison between entrainment velocities produced by a stirring grid, across density interfaces formed with - temperature differences and $O$ salinity differences. (Ref. 6-14) 
Richardson number is of order one, and the entrainment velocity is reduced by a factor of 2 or 3 . As the cloud drifts downwind it mixes with air and becomes less dense, so that density effects diminish and atmospheric turbulence mixing effects play an increasingly more important part in the vapor cloud dispersion. Recent experiments by Britter and Simpson (Ref. 6-15) on negatively buoyant clouds have shown strong turbulent mixing at short distances behind the cloud front for small cloud/air density differences (see Figure 6-5). This rapid large-scale vortex mixing near the front will govern the intermediate stages of the vapor cloud dispersion. The final stages are dominated by turbulent diffusion caused by ambient atmospheric turbulence (i.e., passive diffusion), which depends upon the atmospheric stability, wind speed and surface roughness.

The cloud is heated by heat transferred from the ground or water, by mixing with the air, and by condensation of water vapor in the air. In a hot moist atmosphere this heating could cause the cloud to become slightly positively buoyant, but this appears insufficient to cause the cloud to lift off prior to reaching to the LFL, except under zero wind conditions.

Consider next the rapid spill of a large quantity of LNG from a ship into the water. Since there is no dike, the liquid LNG will spread freely over the water and form a larger vapor source than in the land case. Also, the vapor generation rate per unit area remains high longer for spills on water (Ref. 6-16), apparently because water circulation causes the water surface to remain warm, in contrast with the land case where the dike floor and walls rapidly cool. The vorticity generated from the ship structure is probably of less importance to the vapor dispersion than in a land spill case, since the maximum downwind extent of flammable vapor is large compared to the ship size. 


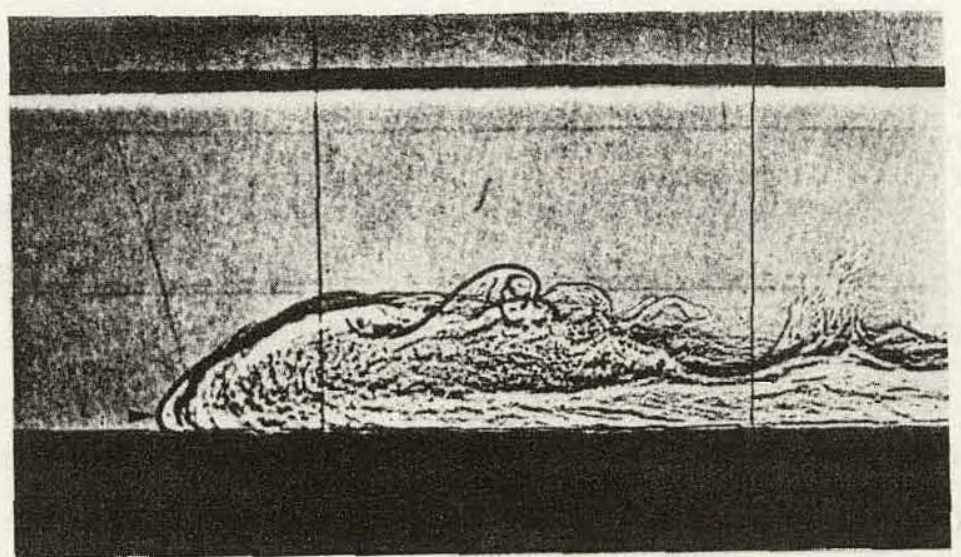

(a)

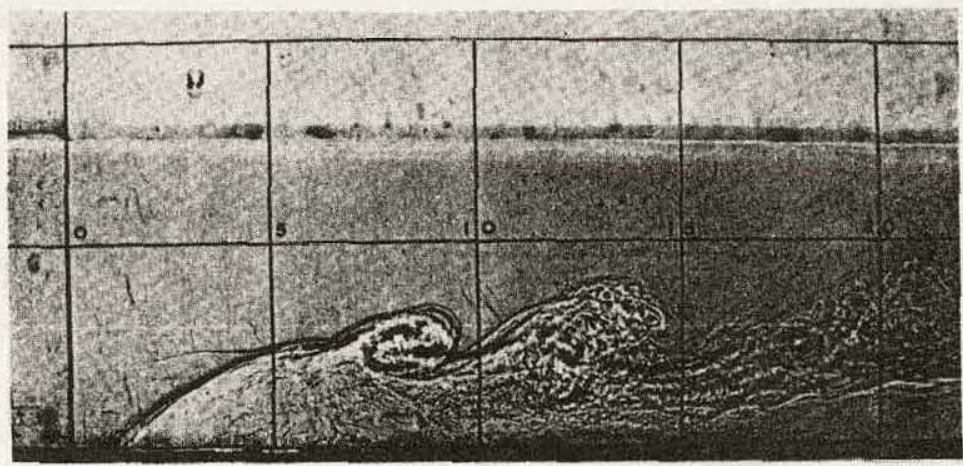

$\left({ }^{2}\right)$

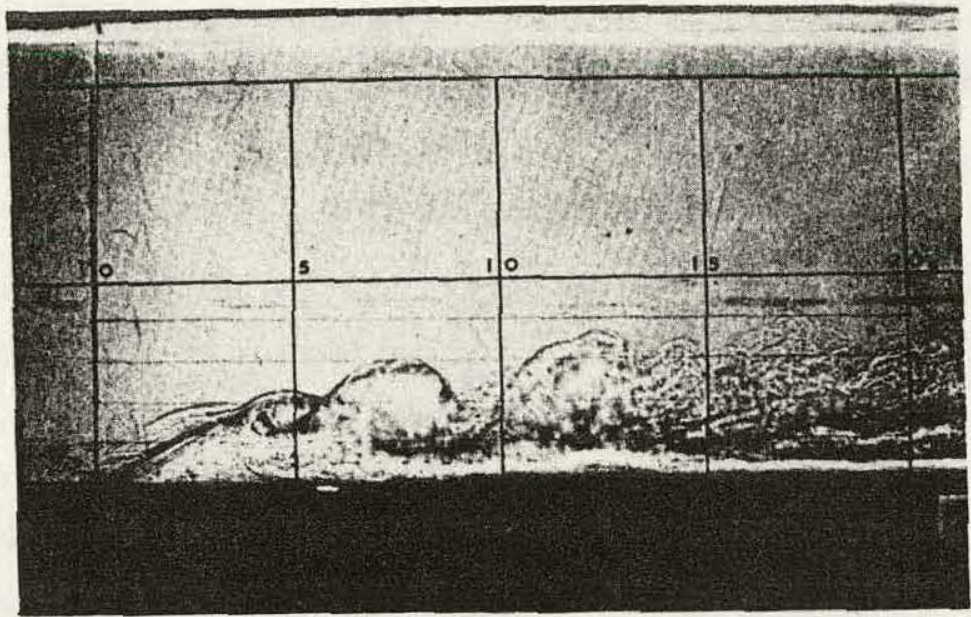

(c)

SHADOWGRAPHS OF GRAVITY CURRENT HEADS BROUGHT TO REST BY AN OPPOSING FLOW WITH UNIFORM VELOCITY PROFILE. (a) WHOLE FLOOR MOVING AT THE SAME VELOCITY AS THE OPPOSING FLOW. THE ARROW INDICATES THE ELEVATION OF THE FOREMOST POINT OF THE GRAVITY CURRENT. $\left(\rho_{2}-\rho_{1}\right) / \rho_{1}=0.0074, \mathrm{~h}_{4} / \mathrm{h}_{1}=0.13$.

(b) WITH A FIXED FLOOR BENEATH THE DENSE FLUID. $\left(\rho_{2}-\rho_{1}\right) / \rho_{1}=0.0037, \mathrm{~h}_{4} / \mathrm{h}_{1}=$ 0.19. (c) WITH A FIXED FLOOR BENEATH THE DENSE FLUID. $\left(\rho_{2}-\rho_{1}\right) / \rho_{1}=0.015$, $h_{4} / h_{1}=0.04$.

Figure 6-5. Examples of turbulent mixing just downstream of a gravity driven cloud. (Ref. 6-15)

$$
6-12
$$


For small spills (tens of cubic meters) gravity effects will be much less important than for large spills, and atmospheric diffusion effects will dominate the vapor cloud dispersion, especially at higher wind speeds.

In summary, the following physical effects are potentially important to the vapor cloud dispersion from large LNG spills:

- Gravity spreading of the cloud.

- Flow field and turbulence of the natural atmospheric boundary layer.

- Vorticity generation by objects in the source region.

- Inhibiting effects of the cold dense LNG cloud on the turbulent mixing.

- Flow deviations and turbulence created by local terrain features.

- Heat transfer from the ground or water.

- Atmospheric water vapor condersation and freezing.

\section{TECHNICAL APPROACH}

In principle, all the above physical mechanisms could be taken into account in three-dimensional (3-D) hydrocode calculations, which could then be used to make predictions of the time-dependent mean concentrations and fluctuations resulting from LNG spills as a function of the various problem parameters. In practice, however, it is not practical to do this accurately solely from first principles. Compromises must be made due to our lack of precise physical models and because of computer limitations. For example, turbulent mixing and rich/lean pockets are especially difficult to predict due to computer storage limitations on the fineness to which the calculations can be zoned. Hydrocodes as well as simplified analytical techniques such as the Germeles-Drake model can be used to make predictions of the vapor dispersion of LNG clouds, but 
the accuracy of these predictions will depend on the sophistication of the tools used. A major portion of the mixing modeling used in the computer codes must be determined experimentally from data. Confidence in the code predictions is established by verifying them with experimental data taken in the appropriate flow regimes.

A second approach is to conduct subscale tests which are scaled simulations of the dispersion of a full-size vapor cloud based on matching of the controlling nondimensional groupings of the physical parameters, and to use this physical modeling to predict full-scale cases. Perfect simulation. requires that all the characteristic nondimensional parameters relevant to the problem (Froude number, Reynolds number, etc.) remain constant from full scale to subscale to preserve dynamic similitude. This is not generally possible, however. In wind tunnel and small field tests, Reynolds numbers are generally smaller than in full-scale spills by one to four orders of magnitude; scaled liquid boiloff rates are difficult to achieve and control in field tests, expecially for spills on water; and scaled heat transfer from water or land surfaces to the cold vapor is difficult to achieve in both wind tunnels and field tests. Hydrocode calculations can be used to investigate the sensitivity of the results to parameters that are difficult to scale or control in tests.

In view of the limitations in both the experimental and theoretical modeling, we believe that a dual approach to the prediction of full-scale LNG vapor cloud dispersion is required:

- Semiempirical scaled modeling using wind tunnel and field experiments.

- Transient, 3-D hydrocode calculations.

For the semiempirical approach, we recommend that scaled simulation tests be performed in medium-size ( $\sim 4-m$ wide) and 
large ( $\sim 40-\mathrm{m}$ wide) wind tunnels as well as in the field. For the hydrocode approach, we suggest that the turbulent mixing models currently employed in the codes first be verified or improved by use of small laboratory shear-layer experiments. The improved code(s) should then be checked by comparison of computed results for LNG dispersion with measurements on windtunnel and field tests, and finally applied to full-scale LNG situations that cannot be completely modeled by such tests. Preliminary code calculations should also be used to assist in designing the wind tunnel and field tests.

A similar approach could be used to develop improved predictions for the vapor dispersion from LPG spills.

\section{EXPERIMENTAL PROGRAM*}

a. Scaling requirements--Due to cost considerations it is impractical to perform full-scale tests on LNG vapor cloud dispersion. We believe, therefore, that dispersion tests should be performed as scaled experiments, both in wind tunnels and in the field. An accurate simulation of full-scale vapor dispersion is achieved when the conditions of similitude are fulfilled. The relative magnitudes (but not necessarily absolute magnitudes) of all terms in the governing equations and boundary conditions as applied to the simulation must be the same as the corresponding relative magnitudes in the description of the. full-scale case. In this way, all pertinent physical phenomena are of the proper relative strength in the simulation.

A scaling analysis of hydrodynamic motion of the LNG vapor reveals that the following dimensionless parameters must be the same in both full-scale and model experiments for perfect simulation:

*A few simple experiments designed to determine basic turbulentmixing parameters for use in mathematical dispersion models are discussed in subsection:VI.5 instead of in this subsection.

$$
6-15
$$




$$
\begin{aligned}
& \mathrm{ul} / \mathrm{v} \quad \text { Reynolds number } \\
& u^{2} / g \ell \quad \text { Froude number } \\
& \text { a/l , Geometric ratio } \\
& Q / \mathrm{ll}^{2} \quad \text { Dimensionless vapor discharge rate } \\
& \mathrm{T}_{1} / \mathrm{T}_{2} \quad \text { Any relevant temperature ratio } \\
& \rho_{s} C_{s} / \rho_{a} C_{a} \quad \text { Ratio of the volumetric heat capacity } \\
& \text { of the surface material to that of. } \\
& \text { air } \\
& \mathrm{K}_{\mathrm{s}} / \mathrm{ul} \quad \text { Dimensionless thermal diffusivity } \\
& \text { of the surface material }
\end{aligned}
$$

where $u$ is a characteristic velocity (such as the wind velocity at a given scaled altitude), \& is a characteristic length (such as a dike length), $v$ is the kinematic viscosity of air, $g$ is the gravitational acceleration, $d$ is any relevant length scale different from $l$ (such as the dike height or the terrain roughness height), $Q$ is the volumetric vapor release rate, $\rho$ and $C$ are the density and specific heat per unit mass of the surface material (subscript $s$ ) or the air (subscript a), and $\mathrm{K}_{\mathrm{s}}$ is the thermal diffusivity of the surface material. The quantity $\mathrm{T}_{1} / \mathrm{T}_{2}$ is the ratio between any two temperatures,. such as the LNG boiling temperature and the ground temperature, or the atmospheric temperatures at the bottom and top of the dike.

Since the ratio $T_{1} / T_{2}$ must be the same in the model as in the full-scale situation, where the two temperatures can be chosen, for example, as the upwind atmospheric temperatures at any two heights, the entire atmospheric temperature profile must be similar in the two cases; i.e., the same except for scale factors in the temperature and height. Moreover, the atmospheric velocity profile must also be similar, or scaled. (The ratio $u_{1} / u_{2}$ is not included in the above list because 
its constancy follows from the constancy of the Froude number, $\mathrm{u}^{2} \mathrm{gl}$, where $\mathrm{u}$ can be the velocity at any desired scaled position.) In time-varying flows the instantaneous velocity and temperature must be scaled, so that in turbulent flows both the mean and the fluctuating velocities and temperatures must be scaled by the same factor.

The (mean) velocity and temperature profiles of atmospheric boundary layers can generally be approximated by formulas involving the sum of a logarithmic and a linear term in the height (Ref. 6-17); in a neutral (adiabatic) atmosphere the linear term drops out. The coefficients in these terms depend upon the "friction velocity" $u$ * and the Monin-obukhov length, $L$, which are defined in terms of the surface stress and the surface heat transfer (Ref. 6-17). For proper modeling, $u * / u$ and $L / l$ must have the same values as in the fullscale situation. However, it is considerably easier to measure the mean velocity and temperature profiles than to measure the surface stress and heat transfer, or the turbulent velocity and temperature correlations that determine these parameters, in order to evaluate $u *$ and $L$. Moreover, the relation between these quantities insures that if the velocity and temperature profiles are properly scaled, ' $\mathrm{u}$ * and $\mathrm{I}$ will also be properly scaled, so the latter conditions are redundant. In addition, this scaling also insures that those turbulent velocity fluctuations that contribute primarily to the stress and heat transfer are also properly scaled. Consequently, the fluctuations that cause vapor dispersion are probably correctly scaled too, although this point deserves further study.

If the atmospheric humidity is.high enough to affect the properties of the vapor-air mixture, it must be added to the list of parameters to be held invariant, and in addition the absolute temperatures (not just the temperature ratios) must 
be duplicated so that moisture condensation and freezing will occur at the same mixture ratio. The Mach number is not included in this list because the flow is essentially incompressible, and the dimensionless vapor-air diffusivity (which determines how molecular diffusion smears the smallest scale concentration variations) has been omitted because (for a given mixture) it is inversely proportional to the Reynolds number.

The above analysis assumes that actual LNG vapor and air are used in the simulation. There appears to be no reason for seeking a substitute for air, but a nonflammable simulant for LNG vapor would have the advantage of increasing the safety of dispersion experiments. A previous study (Ref. 6-4) suggested that the best nonflammable simulant was a fiftyfifty mixture of helium and nitrogen released at the LNG temperature $\left(112^{\circ} \mathrm{K}\right)$. This mixture has the same densitytemperature relation as methane, although when mixed with ambient air its lower specific heat causes the resulting density to deviate by up to 7 percent from that of methaneair mixtures. Such a helium-nitrogen mixture was used in several of the past wind tunnel tests (Refs. 6-3, 6-4). Recently, however, it was realized that the few percent deviation in density can amount to a considerable fraction of the density difference between the diluted vapor cloud and the external air that drives the gravity spreading at intermediate times. In addition, the large molecular diffusivity of helium might smear out the smaller turbulent concentration fluctuations. Accordingly, unless further analysis or tests show that these factors are unimportant or can be corrected for, it appears highly desirable to use actual LNG vapor or cold methane in all simulations. (A mixture containing some heavier hydrocarbons would be required, of course, to investigate differential dispersion of the component vapors.) 
Some wind tunnel simulations have employed a heavy roomtemperature gas, either carbon dioxide (Ref, 6-3) or a freonnitrogen mixture (Ref. 6-4), having a density close to that of cold LNG vapor. Such simulant gases, of course, cannot give information on possible heat transfer effects or on differential dispersion. Moreover, even though heat transfer from boundary surfaces is probably unimportant in full-scale spills (Ref. 6-3), the densities produced when these gases mix with air deviate significantly from those of LNG vapor-air mixtures, especially when the air is moist, since such warm gases do not give the additional buoyancy produced by cold gases when they condense the moisture.

The only ways in which to preserve the same Reynolds number $(u \ell / \nu)$ and Froude number $\left(u^{2} / g l\right)$ in a scaled-down simulation (i.e., one with smaller $l$ ) are to decrease $v$ by pressurizing the apparatus or to increase $g$ by putting it on a centrifuge. Either method would be expensive on a small scale and not feasible on a large scale. To simulate correctly the gravity spreading of the LNG vapor, it is important to keep the same Froude number, $u^{2} / g l$. Accordingly, if $g$ is not varied, the wind velocity (at the same scaled altitude) must be scaled as $\ell^{1 / 2}$, so the Reynolds number will vary like $\ell^{3 / 2}$. Hence, the Reynolds number in a scaled-down field test will typically be one or two orders of magnitude smaller than that in a fullscale spill, while that in a wind tunnel test will be three or more orders of magnitude smaller. Fortunately, measurements have shown that reasonably good simulations of the mean atmospheric dispersion can be obtained even with large variations in Reynolds number, as long as the atmospheric shear layer is properly modeled (which can be done in wind tunnels by special design) and the Reynolds number is kept high enough to maintain fully developed turbulent flow around the model structures (Ref. 6-17). However, the extent to which such 
simulations reproduce the turbulent concentration fluctuations (which may be more sensitive to Reynolds number) has not been determined. An investigation of the scaling of such fluctuations is included in the wind tunnel and field tests recommended in this section.

To maintain the same dimensionless vapor release rate, $Q / \mathrm{ul}^{2}$, in simulation experiments, the boiloff rate per unit area, which is proportional to $Q / \ell^{2}$, must be scaled like $u$, or $e^{1 / 2}$. Methods for varying the boiloff rate approximately. have already been discussed in. Section $V$; further details are given later in the subsections on wind tunnel and field tests. Generally, in wind tunnels it appears that the desired release rates over the desired areas can be obtained by relatively simple mechanical devices. For field tests on land, modification of the dike floor material to reduce its thermal conductivity by the proper factor (generally about a factor of 2) appears to be a reasonable approach. No such modification appears possible for field tests on water, so that simulations of marine spills will have somewhat too high boiloff rates (as well as slightly too small boiloff areas), and probably give too large a distance to a given vapor concentration. However, since in rapid spills on water all of the LNG is vaporized in a relatively short time, it is believed that the concentration at distances beyond a few pool diameters is fairly insensitive to the boiloff rate, so that such simulations can yield useful approximations to the maximum size of the flammable region. Perhaps more important, such simulations can be used to check hydrocode calculations and wind tunnel measurements employing the boiloff rates of the field tests; then the codes and wind tunnels can be applied to situations with full-scale boiloff rates.

-If heat conduction from the earth's surface to the cold vapor cloud is important, the previously.listed dimensionless 
ratios involving the thermal properties of the surface material must be the same in the model as in the full-scale situation. For wind tunnel tests this requires reducing the thermal conductivity of the ground plane by several orders of magnitude while keeping the heat capacity constant, which is not easy to accomplish. Moreover, the heat transfer coefficient from the cloud to the LNG tank and dike depends somewhat on the Reynolds number, which is considerably smaller in the simulation tests. However, analysis suggests that in both fullscale situations and reasonably large field tests the heat transfer is fairly insignificant (Ref. 6-3). In wind tunnel tests, by use of insulating materials it should also be possible to keep the heat transfer negligible, thus achieving a good simulation. The validity of these conclusions can be checked by computer calculations and by tests with similar models that differ only in the thermal conductivity of their materials.

b. Wind tunnel testing--The capability of simulating the wind and temperature profiles and the turbulence spectrum of the atmospheric boundary layer has been demonstrated by the Meteorological wind Tunnel at Colorado State University at air velocities above about $1 \mathrm{~m} / \mathrm{s}$ (Ref. 6-17). However, this tunnel is only $1.8 \mathrm{~m}$ wide, and model LNG dikes or pools used in it must be considerably smaller to avoid wall effects on the vapor dispersion. Accordingly, the wind speed must be scaled down by more than a factor of ten, so that simulation of a moderate wind over a full-scale facility requires a tunnel speed around $0.1 \mathrm{~m} / \mathrm{s}$. At such low speeds most wind tunnels become extremely sensitive to small disturbances and exhibit unrealistic flow oscillations. In addition, the Reynolds number becomes marginal for producing fully developed turbulent flow around small-scale models.

To alleviate. these problems, we recommend that the smallest wind tunnel used in the tests be about $4 \mathrm{~m}$ wide and that some 
tests be performed in a much larger tunnel, about $40 \mathrm{~m}$ wide. Tests in a 4-m low-speed wind tunnel can be carried out relatively rapidly and inexpensively, so that the effects of varying many parameters can be studied at reasonable cost. However, in order to simulate large water spills in wind slower than about $5 \mathrm{~m} / \mathrm{s}$, it is necessary to utilize a larger wind tunnel. Moreover, tests in a considerably larger wind tunnel are also needed in order to determine the possible effects of Reynolds number on both the mean vapor concentrations and the turbulent fluctuations. In such a large tunnel some of the larger instruments designed for field tests can probably be employed.

The sizes and scaling factors of the recommended wind tunnel tests are listed in Table 6-1, together with the sizes of the full-scale spills they are designed to simulate and the sizes of the corresponding field tests (to be discussed later). For reasons discussed in section IV, the simulations cover both a full-tank spill and a small (line-break) spill on water, and spills in both low and high dikes on land. In the land-spill simulations it is not necessary to spill the equivalent of a full. tank of LNG, since the initial period of rapid boiloff can be simulated by a relatively shallow layer in the low dike (which should have a built-up bottom to raise the liquid surface to the proper level), and in the high dike by an annular volume of LNG between the dike and the tank, since the LNG remaining in the tank during an accident spill does not boil off significantly.

Suitable wind tunnels for the two sizes of tests are the Environmental Wind Tunnel at Colorado State University $13.7 \mathrm{~m}$ wide) and: the large low-speed wind tunnel being reconstructed at NASA-Ames ( $37 \mathrm{~m}$ wide). The Environmental wind Tunnel has a provision for creating an appropriate velocity boundary layer, but not a thermal boundary layer; however, the latter 
TABLE 6-1. SIZES OF CREDIBLE FULL-SCALE SPILLS AND OF CORRESPONDING SCALED-DOWN FIELD AND WIND TUNNEL TESTS

\begin{tabular}{|c|c|c|c|c|}
\hline & Full scale & Field test & $\sim$ 40-m wind tunnel ${ }^{a}$ & $\sim 4-m$ wind tunnel $\left.\right|^{a}$ \\
\hline \multicolumn{5}{|l|}{ Water spills } \\
\hline Ship $\lg \times$ wd $\times$ ht $(m)$ & $280 \times 40 \times 16$ & $68 \times 9.8 \times 3.9$ & $1.9 \times 0.27 \times 0.11$ & $0.28 \times 0.04 \times 0.016$ \\
\hline Length scale factor & 1 & $1 / 4.1$ & $1 / 150$ & $1 / 1000$ \\
\hline Velocity scale factor & 1 & $1 / 2.0$ & $1 / 12$ & $1 / 32$ \\
\hline Large spill volume $\left(\mathrm{m}^{3}\right)$ & 25,000 . & 350 & 0.0074 & $25 \mathrm{~cm}^{3}$ \\
\hline Large spill max pool diam $(\mathrm{m})$ & 770 & $150^{b}$ & 5.1 & 0.77 \\
\hline Small spill volume & $25 \mathrm{~m}^{3}$ & $0.39 \mathrm{~m}^{3}$ & $7.4 \mathrm{~cm}^{3}$ & $\left(0.025 \mathrm{~cm}^{3}\right) \mathrm{c}$ \\
\hline Small spill max pool diam & $60 \mathrm{~m}$ & $12 \mathrm{~m}$ & $0.4 \mathrm{~m}$ & $(6 \mathrm{~cm})$ \\
\hline \multicolumn{5}{|l|}{ Land spills } \\
\hline Tank diam $\times \mathrm{ht}(\mathrm{m})$ & $36 \times 30$ & $11.5 \times 9.5$ & $1.8 \times 1.5$ & $0.29 \times 0.24$ \\
\hline Length scale factor & 1 & $1 / 3.2$ & $1 / 20$ & $1 / 125$ \\
\hline Velocity scale factor & 1 & $1 / 1.8$ & $1 / 4.5$ & $1 / 11$ \\
\hline Low-dike $\lg x$ wd $x$ ht $(\mathrm{m})$ & $95 \times 81 \times 4$ & $30 \times 25 \times 1.3$ & $4.8 \times 4.1 \times 0.2$ & $0.76 \times 0.65 \times 0.032$ \\
\hline Low-dike spill volume & 28,000 & $100 \mathrm{~m}^{3^{0}}$ & $0.15 \mathrm{~m}^{3^{0}}$ & $590 \mathrm{~cm}^{3^{0}}$ \\
\hline High-dike diam $\times$ ht $(m)$ & $40 \times 30$ & $12.5 \times .9 .5$ & $2 \times 1.5$ & $0.32 \times 0.24$ \\
\hline High-dike spill volume & 28,000 & $150 \mathrm{~m}^{3^{e}}$ & $0.73 \mathrm{~m}^{3^{e}}$ & $2800 \mathrm{~cm}^{3^{e}}$ \\
\hline
\end{tabular}

although spill volumes are given in terms of (liquid) LNG, for wind tunnel tests involving small volumes spread over relatively large areas it is more practical to release the hydrocarbon as a cold gas.

${ }^{b}$ The LNG pool diameter on field tests does not quite follow the length scale factor, since the boiloff rate on water cannot be scaled.

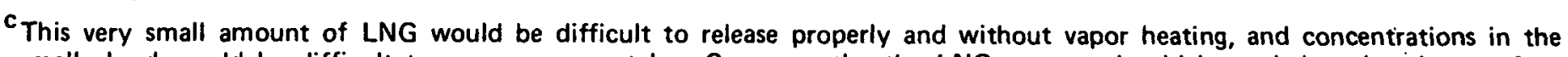
small cloud would be difficult to measure accurately. Consequently, the LNG amount should be scaled up by about a factor of 100 , and the ship model correspondingly scaled up by a linear factor of 4.6 for these tests.

d. Volume sufficient to simulate the early period of rapid boiloff. (Field-test value includes additional depth to allow for ground irregularities.)

e Volume sufficient to fill the annular region between the tank and the high dike where the boiloff actually occurs. Could be decreased further by decreasing the volume of the bottom part of the annulus while maintaining the same warm surface area (or boiloff rate). 
could be added at reasonable cost, as could a device for changing the air humidity.* The Ames wind tunnel, which is expected to be rebuilt by January 1982, provides only a large working section in which the wind speed can be varied down to zero (or even reversed), and into which users can insert their own test beds.** On government-sponsored projects there is no charge for operation of this tunnel. For vapor dispersion tests, a test bed would have to be constructed that incorporated upstream turbulence generators (to simulate the atmospheric boundary layer), model LNG ships or tanks and dikes, appropriate vapor release devices, and instrumentation for measuring gas velocities and concentrations. It would be difficult to produce a thermally stratified boundary layer in this large tunnel, but tests in a neutral atmosphere (combined with similar tests in the smaller wind tunnel and in the field) should provide adequate information on the possible effects of Reynolds number and dimensionless thermal diffusivity on the vapor dispersion.

Both the Environmental Wind Tunnel and the Ames tunnel can be run in an "open-cycle" mode, without recirculating the air, so it is believed that actual LNG vapor (or methane) can be safely released in the tests without building up a flammable concentration in the bulk of the tunnel. For tests in the smaller tunnel, where the scaled amounts of LNG required are quite small (Table 6-1), it is probably more convenient to meter and release the hydrocarbon as a cold gas rather than as a liquid. A suitable gas valve, giving a timevarying release rate simulating that of a dike spill, was designed by Colorado State University investigators and

\footnotetext{
*Discussion with R. N. Meroney, Colorado State University, June $6,1979$.

**Discussion with M. Kelly and J. Kirk, NASA-Ames, May 17, 1979.
} 
employed in their wind tunnel (using a cold simulant gas) (Ref. 6-3). To model water spills, a mechanical floor plate that releases the gas over an expanding area should also be constructed.

In the large wind tunnel, actual spills of LNG onto a surface precooled to scale down the boiloff rate appear simpler, and have the added advantage of giving a differential boiloff of the ethane and propane components that is probably similar to that of full-scale spills. (This suggestion should be checked by composition measurements just above the liquid on both wind tunnel and field tests.) To simulate land spills the thermal conductivity of the surface material must also be scaled down, while for water spills a thick conductive material should be used to maintain a constant boiloff rate per unit area, together with a mechanically expanding circular dam to . vary the liquid pool radius properly with time, unless calculations and tests in the smaller wind tunnel (see below) show that essentially the same vapor concentration fields are produced by a vapor source with a radius fixed at an appropriate value.

If one wishes to study LPG vapor dispersion, the same two wind tunnels can be employed in scaled tests similar to those recommended for LNG. Separate boiloff and spreading tests, such as those described in section $v$, should first be carried out to determine the proper rate for an LPG vapor release or the proper floor material and temperature for a liquid spill in the wind tunnel, in order to simulate a full-scale spill. The instrumentation in the wind tunnels could be virtually the same as for the LNG tests, except that sensors that distinguish between the major components of LPG (propane and butane) are probably unnecessary because the detonation properties of these two hydrocarbons are quite similar (see section IX). 
c. Test program for the smaller wind tunnel--The specific tests recommended for water spill simulations in the $4-\mathrm{m}$ wind tunnel are listed in Table 6-2. This list may be modified on the basis of the results of the preliminary code calculations described in subsection VI.5. To avoid possible interference between concentration sensors placed closely upwind/downwind of each other and to minimize the number of sensors required, each "test" should consist of about five test runs that are identical except that the sensors are deployed at different positions. In addition, in the first test set and occasionally later on, a run should be completely duplicated to determine the reproducibility of the measurements.

The first three tests are designed to determine if the cloud from a realistic expanding vapor source can be closely simulated by a constant-size source, which would simplify the release apparatus required for the large wind tunnel. The" best size to choose could be determined beforehand by matching the early vapor-cloud sizes calculated by a Germeles-Draketype analysis (Ref. 6-5) or a hydrocode. The remaining tests are designed to determine the effects of varying the several meteorologic and geometric parameters listed in the column headings and in footnote $c$ of Table 6-2. To keep the test program within a reasonable size, only a fraction of the possible combinations of parameters are included. It is believed that the humidity, boiloff rate (within the indicated factor of 2), presence and orientation of the ship, and perhaps even the atmospheric stability have only a minor influence on the vapor dispersion (except for the ship structure in the smallspill case), so that just a few tests in which these parameters are varied will provide adequate practical information. Before the tests, this belief should be checked by the preliminary code calculations described in Subsection VI.5, and changes made in the list if necessary. 
TABLE 6-2. RECOMMENDED TESTS IN A MEDIUM-SIZE WIND TUNNEL ( $4 \mathrm{M}$ WIDE) FOR MODELING THE VAPOR. DISPERSION FROM LARGE AND SMALL LNG SPILLS ON WATER (LINEAR SCALE FACTOR 1/1000)

\begin{tabular}{|c|c|c|c|c|c|c|}
\hline $\begin{array}{l}\text { Test } \\
\text { no. }\end{array}$ & $\begin{array}{l}\text { Simulated } \\
\text { wind speed } \\
(\mathrm{m} / \mathrm{s})\end{array}$ & $\begin{array}{l}\text { Atmos. } \\
\text { stabil. }\end{array}$ & Humidity & $\begin{array}{l}\text { Vapor } \\
\text { release } \\
\text { rate }\end{array}$ & $\begin{array}{l}\text { Ship } \\
\text { models }\end{array}$ & $\begin{array}{l}\text { LNG } \\
\text { ship. } \\
\text { orient. }\end{array}$ \\
\hline $\begin{array}{c}1-3^{c} \\
4-6 \\
7-9^{d} \\
10-12 \\
13-15 \\
16-18 \\
19-21 \\
22-24 \\
25 \\
26^{9} \\
27^{9} \\
28-30^{g} \\
31-33^{g} \\
34-48\end{array}$ & $\left.\right|_{5,10,20} ^{1}$ & gency & Low & $\begin{array}{l}\text { Nominal } \\
\text { Half nom. } \\
\text { Twice nom. } \\
\text { Nominal }\end{array}$ & $2^{e}$ & $\begin{array}{c}- \\
- \\
- \\
- \\
\text { Along wind } \\
\text { Crosswind }\end{array}$ \\
\hline
\end{tabular}

aBecause of instrumentation limitations (see text), each "test" will probably consist of about 5 test runs.

${ }^{b}$ Divide by 32 to get actual wind speed in tunnel.

COn tests 1-3, vapor is released over a constant area; other tests have expanding area, modeling a full-scale expanding LNG pool.

d Tests 7-9 are just like tests 4-6. except that they include a model of a cliff shoreline some distance downwind from the spill.

eModel of ships colliding broadside.

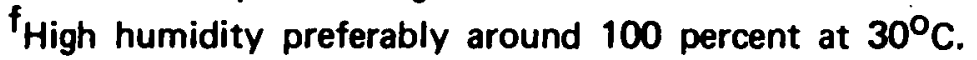

9Simulations of a small "line-break" spill lall other tests simulate a $25,000, \mathrm{~m}^{3}$ spill). These small spill simulations should include a model of a cliff shoreline. 
As mentioned earlier, modeling of wind speeds below $5 \mathrm{~m} / \mathrm{s}$ is not recommended for the smaller tunnel. Moreover, for an F-stability condition wind speeds above $5 \mathrm{~m} / \mathrm{s}$ are also omitted because in the actual atmosphere higher winds mix the boundary layer and cause it to approach a neutral (D) condition. The purposes of the tests with half or twice the nominal "best estimate" boiloff rate are to determine the effects of uncertainties or variabilities in the boiloff rate (the latter possibly due to water waves; see section $V)$, and also the effects of inability to scale the boiloff rate for the field tests on water, as discussed earlier.

At the end of the list, 15 contingency tests are included. These permit repetition of any of the tests which gave incomplete or questionable data and further exploration of the effects of varying those parameters shown by the earlier tests to be most significant.

The recommended tests for simulating spills in low and high dikes in the 4-m wind tunnel are shown in Table 6-3. The list is roughly parallel to that for the water spills, and the rationale is similar. Tests $1-3$ are for determining whether the wind flow disturbances caused by the tank and low-dike structures have significant effects on the vapor concentrations far downwind. The tests employing a constant vapor release rate are intended to check the idea that the total release rate from a spill in a dike may vary slowly enough that the vapor dispersion approximates a steady state, so that the maximum downwind extent can be determined by a steady release at the maximum rate. However, this idea was based on wind-tunnel measurements (Ref. 6-3) which modelled a dike boiloff rate that was assumed to be constant for the first $100 \mathrm{~s}$ (limited by film boiling), before falling off due to surface cooling. Recent boiloff measurements of LNG on soil and water (see section V)--indirectly supported by published measurements of nonhydrocarbon liquids 
TABLE 6-3. RECOMMENDED TESTS IN A MEDIUM-SIZE WIND TUNNEL ( $\sim 4$ M WIDE) FOR MODELING THE VAPOR DISPERSION FROM LNG SPILLS IN LOW AND HIGH DIKES (LINEAR SCALE FACTOR 1/125)

\begin{tabular}{|c|c|c|c|c|c|c|}
\hline $\begin{array}{l}\text { Test } \\
\text { no. }^{a}\end{array}$ & $\begin{array}{l}\text { Simulated } \\
\text { wind speed } \\
(\mathrm{m} / \mathrm{s})\end{array}$ & $\begin{array}{l}\text { Atmos. } \\
\text { stabil. }\end{array}$ & Humidity & $\begin{array}{c}\text { Dike } \\
\text { model }^{c}\end{array}$ & $\begin{array}{l}\text { Vap. rel. } \\
\text { rate } \\
\text { corres. to }\end{array}$ & $\begin{array}{l}\text { Dike } \\
\text { orient. } \\
\text { to wind }\end{array}$ \\
\hline $\begin{array}{c}1-3 \\
4-6 \\
7-9 \\
10-12 \\
13-15 \\
16-18 \\
19-21 \\
22-24 \\
25 \\
26 \\
27-29 \\
30-32 \\
33-35 \\
36-38 \\
39-41 \\
42 \\
43 \\
44-60\end{array}$ & $\left.\right|_{5,10,20} ^{\mid}$ & gency & $\left.\right|_{\text {Low }}$ & $\begin{array}{l}\text { None } \\
\text { Low dike }\end{array}$ & Soil & Not appl. \\
\hline
\end{tabular}

aBecause of instrumentation limitations (see text), each "test" will probably consist of about 5 test runs.

${ }^{b}$ Divide by 11 to get the actual wind speed in the tunnel.

CAli tests include a model of both tank and dike, except tests 1-3, where the vapor is simply released at the ground level over an area corresponding to that of a low dike.

${ }^{d}$ Constant vapor release rate to be set later (see text).

Epreferably around 100 percent humidity at $30^{\circ} \mathrm{C}$. 
showing that addition of a few percent of a second liquid can double the film-boiling limit (Ref. 6-18)--strongly suggest that the LNG boiloff rate per unit area on most materials decreases by about a factor of 3 between 10 and $100 \mathrm{~s}$. If a catastrophic rupture occurred and produced a hole in the tank $10 \mathrm{~m}$ in diameter or larger, the escaping LNG would fill most of the impound volume within $10 \mathrm{~s}$, in both the low- and highdike situations, and if the dikes were uninsulated the vapor would fill the remaining volume and spill over the top within the same time period. Consequently, constant release-rate tests may be relevant only to slower spills or spills in insulated dikes. This question should be investigated in the preliminary numerical studies described in subsection VI. 5 before a decision is made on the best release rate to be used in the wind tunnel.

The instrumentation recommended for the tests in the smaller wind tunnel includes about 10 TSI vapor concentration sensors, each containing two thin-film elements in a small aspirated tube (Refs. 6-3, 6-4). One film is unheated and used as a resistance thermometer; the other is electrically heated to a constant temperature, so the required current indicates the thermal conductivity and hence the composition of the gas. Such sensors were used successfully in recent LNG field tests by the Lawrence Livermore Laboratory (LLL) (Ref. 6-19). However, to avoid lengthening their basically short time response, which is especially important in scaled-down tests, we recommend omitting the copper tube used by LLL to heat the gas and vaporize any water droplets before they enter the sensor, or perhaps replacing it with a very small cyclone-type particle separator (Ref. 6-3), if needed for the tests in moist air.

All but one or two of the TSI sensors should be deployed in a planar pattern covering the height and half the width of the vapor cloud at one downstream distance. (Coverage on only one 
side of the centerline is sufficient, due to symmetry.) on different runs this group of sensors would be moved to different distances downstream, thus covering the whole cloud volume while avoiding placing any sensor in the wake of another sensor. The remaining TSI gages should be stationed at fixed points in the other half of the cloud to check the symmetry of the concentration field and the reproducibility of the different runs.

If one of the optical concentration sensors being developed for field tests (Ref. 6-19) becomes available and has reasonable spatial resolution, it might also be used in the wind tunnel, provided that it could be placed where it would not disturb the other measurements. A similar statement applies to the use of small grab-bottles to take gas samples (Ref. 6-19). Since no attempt to simulate the differential boiloff of the heavier hydrocarbons is recommended for the smaller wind tunnel, such additional concentration instrumentation does not have a high priority.

Small thermocouples should be stationed close to several of the TSI sensors to check the temperature measurements of the latter and to measure with higher time resolution the temperature fluctuations, which are expected to reflect to a considerable extent the concentration fluctuations (Ref. 6-19). In addition, a hygrometer, a few hot-wire anemometers, and thermocouples for the F-stability runs should be placed upstream of the vapor release to measure the humidity and check the simulation of the atmospheric velocity and temperature profiles, including turbulent fluctuations, at least for one run under each atmospheric condition. On other runs the upstream instrumentation could be minimal.

Photographs of the vapor cloud and its motion can also be extremely useful and enlightening. In previous wind tunnel tests using a cold simulant gas, condensation of the moisture in the air was sufficient to produce a visible cloud (Ref. 6-4). 
Accordingly, all that is required is a still camera and a movie camera, each to take simultaneous pictures of the cloud from the side and the top with the aid of a mirror near the tunnel.

\section{d. Test program for the large wind tunnel--The tests} recommended for simulating the vapor dispersion from LNG spills in the planned NASA-Ames $37-\mathrm{m}$ wind tunnel, or similar large wind tunnel, are listed in Table 6-4. It should be emphasized, however, that this list is tentative, since the results of the calculations and tests in the smaller wind tunnel should be available to improve the planning before this series is run.

The tests are roughly parallel to those recommended for the smaller wind tunnel (Tables 6-2 and 6-3), with the addition of some lower wind speeds (including two with zero wind) and the omission of F-stability tests, due to the previously discussed capabilities and limitations of the large wind tunnel. Since the constraints on the testing time and costs will be greater on these tests than on those in the smaller tunnel, all tests at $20 \mathrm{~m} / \mathrm{s}$ and most at $5 \mathrm{~m} / \mathrm{s}$ have been omitted. The time and cost are further reduced by deploying enough concentration. sensors to cover the entire cloud in one run, rather than the five runs employed in the smaller tunnel to avoid spacing the sensors so closely together that they interfere with each other.

A high humidity is specified for a few of the tests. The cost of constructing a device to control the humidity accurately in this large tunnel does not appear warranted, but we believe that a simple water spray at the tunnel intake will increase the humidity sufficiently to determine if it has a perceptible effect on the vapor dispersion. A few tests are included specifically to simulate the field tests on water (see Table 6-1 and Subsection VI.4.e.); for these, the vapor must be released at a total rate of 40 percent greater and an area 30 percent smalier than for the tests that simulate full-size spills, because the 
TABLE 6-4. RECOMMENDED TESTS IN A LARGE WIND TUNNEL ( 40 M WIDE) FOR MODELING THE VAPOR DISPERSION FROM LNG SPILLS (LINEAR SCALE FACTOR $1 / 150$ FOR SPILLS ON. WATER, TESTS $1-20$, AND $1 / 20$ FOR SPILLS ON LAND, TESTS $21-38$ )

\begin{tabular}{|c|c|c|c|c|c|}
\hline $\begin{array}{l}\text { Test } \\
\text { no. }\end{array}$ & $\begin{array}{l}\text { Simulated } \\
\text { wind speed } \\
(\mathrm{m} / \mathrm{s})\end{array}$ & Humidity. & $\begin{array}{l}\text { Ship } \\
\text { or dike } \\
\text { model }\end{array}$ & $\begin{array}{l}\text { Vap. rel. } \\
\text { rate } \\
\text { corres. to }\end{array}$ & $\begin{array}{l}\text { LNG ship } \\
\text { or dike } \\
\text { orient. }\end{array}$ \\
\hline $1-2$ & $2.5,10$ & Low & None & Water & - \\
\hline $3-6$ & $0,2.5,5,10$ & & 2 ships b & & Crosswind \\
\hline $7-8$ & $2.5,10$ & High & & & \\
\hline $9-10$ & & Low & & & Along wind \\
\hline $11-12^{c}$ & & & & & Crosswind \\
\hline $13-14^{C}$ & & : & & Wat. fld. & \\
\hline $15-16$ & & & & & \\
\hline $17-18^{e}$ & & & 1 ship & & \\
\hline $19-20^{e}$ & & & & Water & \\
\hline $21-22$ & & & None ${ }^{f}$ & Soil & \\
\hline $23-26$ & $0,2.5,5,10$ & & Low dike 9 & & \\
\hline $27-28$ & $2.5,10$ & High & & & \\
\hline $29-30$ & & Low & & & $45^{\circ}$ \\
\hline $31-32$ & & & & Insul. & Crosswind \\
\hline $33-34$ & & & High dikeg & Nominal & Not appl. \\
\hline $35-36$ & & High & & & \\
\hline $37-38$ & & Low & 1 & Insul. & 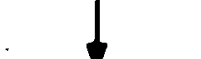 \\
\hline $39-43$ & \multicolumn{5}{|c|}{ Contingency tests; parameters to be determined later } \\
\hline
\end{tabular}

a To get the actual wind speed in the tunnel, divide by 12 for tests 1-22 and by 4.5 for tests 23-40. After results from numerical calculations and tests in the smaller wind tunnel become available, the wind speeds in these tests should be adjusted, if necessary, to bracket the speeds that give the maximum LFL distance and the maximum volume of flammable vapor-air mixture.

b Model of ships colliding broadside.

C Tests 11 - 14 include a model of a cliff shoreline some distance downwind.

d The vapor release rate and area of tests $13-18$ are scaled to simulate the field-test spills on water, which implies a faster release rate and a. smaller area than for those tests that simulate full-size spills (see text).

"Tests 17-.20 simulate a small "line-break" spill on water; they should include a model of a cliff shoreline.

fVapor released from a rectangular area like that. of the low dike but flush with the ground.

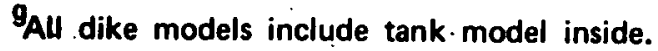


boiloff rate cannot be correctly scaled in the field tests on water (see Subsections V.2.b and VI.4.b). The results of these tests can also be used to determine the effects of water waves on the vapor cloud, if the "swimming pool" tests described in Section $V$ show that such waves affect the boiloff rate.

The instrumentation recommended for the large wind tunnel is similar to that for the smaller wind tunnel, except that enough TSI sensors are employed to cover the entire flammable region in one test run, and several optical sensors and grab bottles are employed above the spill area and downwind in the cloud area to measure differential boiloff and dispersion of the heavier hydrocarbon components. Such instruments are needed for the field tests and probably can be borrowed for the large tunnel tests without additional expense. The effort put into measurements of the heavier hydrocarbons should be adjusted in accordance with the results available at that time from the swimming pool tests and detonation studies described in Sections $\mathrm{V}$ and IX, respectively.

Figure 6-6 shows one possible arrangement of the TSI sensors in the NASA-Ames wind tunnel, together with the upstream turbulence generators for simulating the atmospheric boundary, a tank and dike model, and hot-wire anemometers, all mounted on a test bed and preassembled outside the wind tunnel. Because of the large size of the tunnel, it is believed that the large number of sensors shown can be deployed without seriously affecting the measurements of sensors downwind.

Devices for holding and spilling the LNG (not shown) would be built within the tank and ship models.

e. Field test program--The wind tunnel tests described above are expected to answer most of the important questions about LNG vapor dispersion. However, to answer the remaining ones (such as the effects of large Reynolds numbers) and to improve our confidence in the answers obtained by Froude-number 


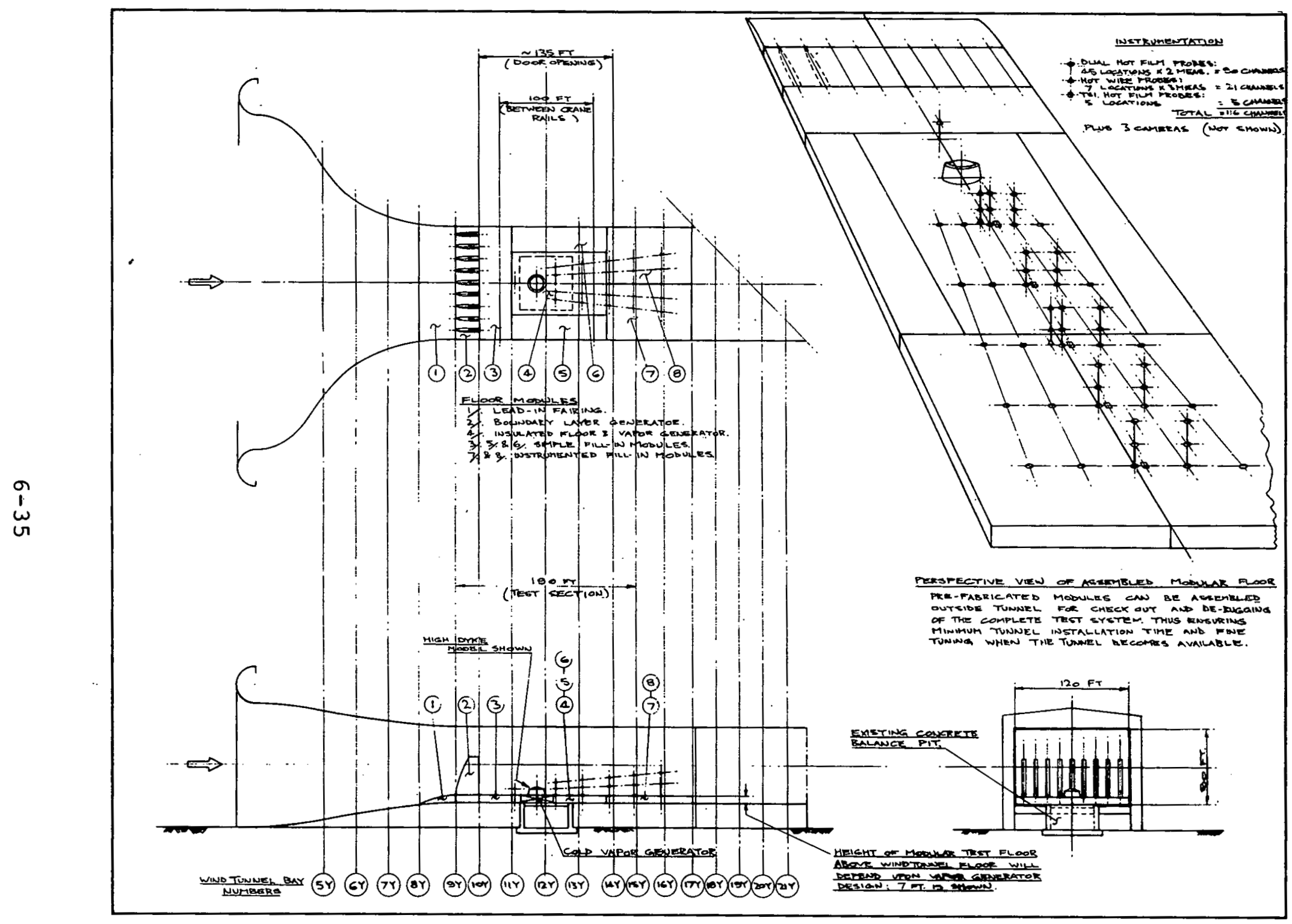

Figure-6-6: Layout of the test section for LNG vapor dispersion measurements in the future NASA-Ames $37-\mathrm{m}$ wind tunnel. 
modeling, some field tests of relatively large size are required. More than 10 such tests are needed to cover just the most important combinations of spill and meteorological parameters (see below). If amounts of LNG approaching that in an actual ship tank or storage tank had to be spilled in a test, the cost would be prohibitive. Fortunately, following Froude scaling, the LNG amount required can be reduced by a factor of 70 , from $25,000 \mathrm{~m}^{3}$ to $350 \mathrm{~m}^{3}$, for example, if the wind speed is reduced by a factor of approximately 2 . Since reasonably steady winds down to about $1 \mathrm{~m} / \mathrm{s}$ can be found with fair frequency at many places during the right season, this means that full-scale winds down to $2 \mathrm{~m} / \mathrm{s}$ can be simulated. In such simulations the Reynolds number will be smaller by a factor of 8 than in full-scale spills, but turbulent flows generally vary only slowly with Reynolds number, especially in this high Reynolds number region.

The cost of $350 \mathrm{~m}^{3}$ of LNG is comparable to the other costs of a careful and well-instrumented field test. Moreover, surplus cryogenic tanks of this capacity are available at reasonable cost and can be moved by conventional trucks. " Going to smaller field tests would not save much money, and would limit the Reynolds number and simulated wind speed more seriously. Going to somewhat larger field tests, say $1000 \mathrm{~m}^{3}$, would be considerably morè expensive and provide only a small improvement in simulation.

Because the maximum LFL distances predicted by the GermelesDrake and the SIGMET mathematical models agree quite well for spills of up to $1000 \mathrm{~m}^{3}$ on water (in a $2.2 \mathrm{~m} / \mathrm{s}$ wind), but disagree by increasing amounts for larger spills (see Fig. 6-1, p. 6-3), it has been suggested that test spills larger than $1000 \mathrm{~m}^{3}$ are required to distinguish between the models. However,

*Discussion with J. Gibson, Gibson Cryogenics, Inc., June 25, 1979 
not just the LFL distance but also the cloud width, height, flammable volume, etc., should be compared to validate a model. Moreover, if a scaled field test using a $350-\mathrm{m}^{3}$ spill but simulating a $25,000-\mathrm{m}^{3}$ spill is carried out, as proposed here, the results can be compared directly (after scaling) to the model calculations for $25,000-\mathrm{m}^{3}$ spills, where the Germeles-Drake and SIGMET LFL distances differ by a factor of 2. The fieldtest results can also be used to evaluate other mathematical models and wind tunnel tests.

The sizes and scaling factors recommended for the field tests on land and water were given in Table 6-1 (p. 6-23). For the large spills on water, an LNG volume of $350 \mathrm{~m}^{3}$ is recommended, resulting in a linear scale factor of $1 / 4.1$. Consequently, a large ship model is required, $68 \times 9.8 \times 3.9 \mathrm{~m}$ in dimensions; however, a rough box structure of plywood or other inexpensive material should be adequate to simulate the local flow field near the ship. The wind tunnel tests may show that the ship structure has a negligible effect on the LFL distance (since it is many times the ship dimensions), but perhaps a significant effect on a vapor-cloud fire, and certainly an effect on a small "line-break" spill next to the ship. Since a ship model is needed for the latter tests, it may as well be used for all of the water spill tests.

If simulations of $25-\mathrm{m}^{3}$ line-break spills are performed at the same linear scale $(1 / 4.1)$, test spills of only $0.35 \mathrm{~m}^{3}$ are required. It would not be difficult to spill a considerably larger amount of LNG, or even to go to a full-scale $25-\mathrm{m}^{3}$ spill. However, this size increase would require construction of a much larger ship model, which does not seem to be justified unless the wind tunnel results and further analyses show that such larger tests are really needed.

The large test spills on water require a pond or lake at least $200 \mathrm{~m}$ in diameter; however, the water can be quite shallow 
except at the spill point (where it should be deeper than the height of the spill tank, to prevent the LNG stream from striking the bottom). To simulate the atmospheric boundary layer over relatively calm water, and the vapor cloud dispersion as it travels a considerable distance over water before reaching shore, which is probably the situation of greatest practical importance, either the pond must extend considerably farther or it must be surrounded by smooth and level ground. Construction of a suitable test site in a region where large expanses of flat land are available, such as at the DOE Nevada Test site, should be a straightforward task, provided that an adequate water supply is available.

Large spills in dikes on land can be modeled on a scale comparable to that recommended for the water spills (see Table 6-1) while using only 100 to $150 \mathrm{~m}^{3}$ of $\mathrm{LNG}$. The reduction in LNG amount is made possible in the low dike by raising the floor level and spilling a shallower layer of liquid, as discussed in section $V$. In the high dike, only the annular region between the dike and the tank needs to be filled; no LNG needs to remain in the tank. However, the tank cannot be raised very high because that would disturb the local air flow and vapor mixing, so either a pump or compressed nitrogen must be supplied to empty the tank into the dike.

As explained in section $V$, the materials used in the dike floor and walls must have thermal conductivities a factor of 1.8 smaller than those of the full-scale materials to properly scale down the boiloff rate. Suitable materials should not be difficult to find, since variations in composition, compaction and moisture content of typical soils and concretes can lead to changes in thermal conductivity comparable to those required.

Scaling of the atmospheric boundary layer can be more difficult. As already mentioned, the wind speed (at the same scaled height) must be decreased by about a factor of 2 . Since steady 
winds below $1 \mathrm{~m} / \mathrm{s}$ can rarely be found, simulation of wind speeds below $2 \mathrm{~m} / \mathrm{s}$ is not feasible in these tests. However, this is probably not a serious deficiency because current vapor dispersion calculations suggest that higher winds produce the longest LFL distance from rapid LNG spills (Ref. 6-8). * To model the vertical wind profile, the surface roughness at the test site must be reduced by the linear scale factor (1/4.I for the water spills and 1/3.2 for the land spills), which does not appear to be difficult. In addition, the vertical temperature gradient must be increased by the same factor. For a neutral atmosphere (D-stability) this gradient vanishes and there is no modeling problem, but modeling a stable atmosphere requires a much more stable atmosphere for subscale tests. Accordingly, simulation. of a full-scale F-stability condition may not be possible in the field, and one may have to settle for an E-stability. If preliminary meteorological measurements at the chosen test site show this to be the case, some of the contingency tests in the wind tunnels should be assigned to class $\mathrm{E}$ conditions.

Table 6-5 lists the field tests currently recommended for investigating LNG vapor dispersion. However, it is expected that the results of the earlier wind tunnel tests and mathematical modeling described elsewhere in this section, and limitations of the available meteorological conditions during the tests, will cause some modifications in this test plan. The field tests listed in the table comprise a subset of those recommended for the wind tunnels, with the cases of lesser practical importance omitted because of the greater cost of field tests.

The instrumentation recommended for these tests is listed in Table 6-6. It is similar to that recommended for the wind

\footnotetext{
*For slower, quasi-steady spills, not treated here because of their lesser importance to public safety, low-wind conditions are probably more critical, but such spills can be simulated without scaling them down so much, while still using a reasonable amount of LNG.
} 
TABLE 6-5. RECOMMENDED FIELD TESTS FOR MODELING THE VAPOR DISPERSION FROM LNG SPILLS (LINEAR SCALE FACTOR 1/4.1 FOR SPILLS ON WATER, TESTS $1-9$, AND $1 / 3.2$ FOR SPILLS ON LAND, TESTS $10-21)$

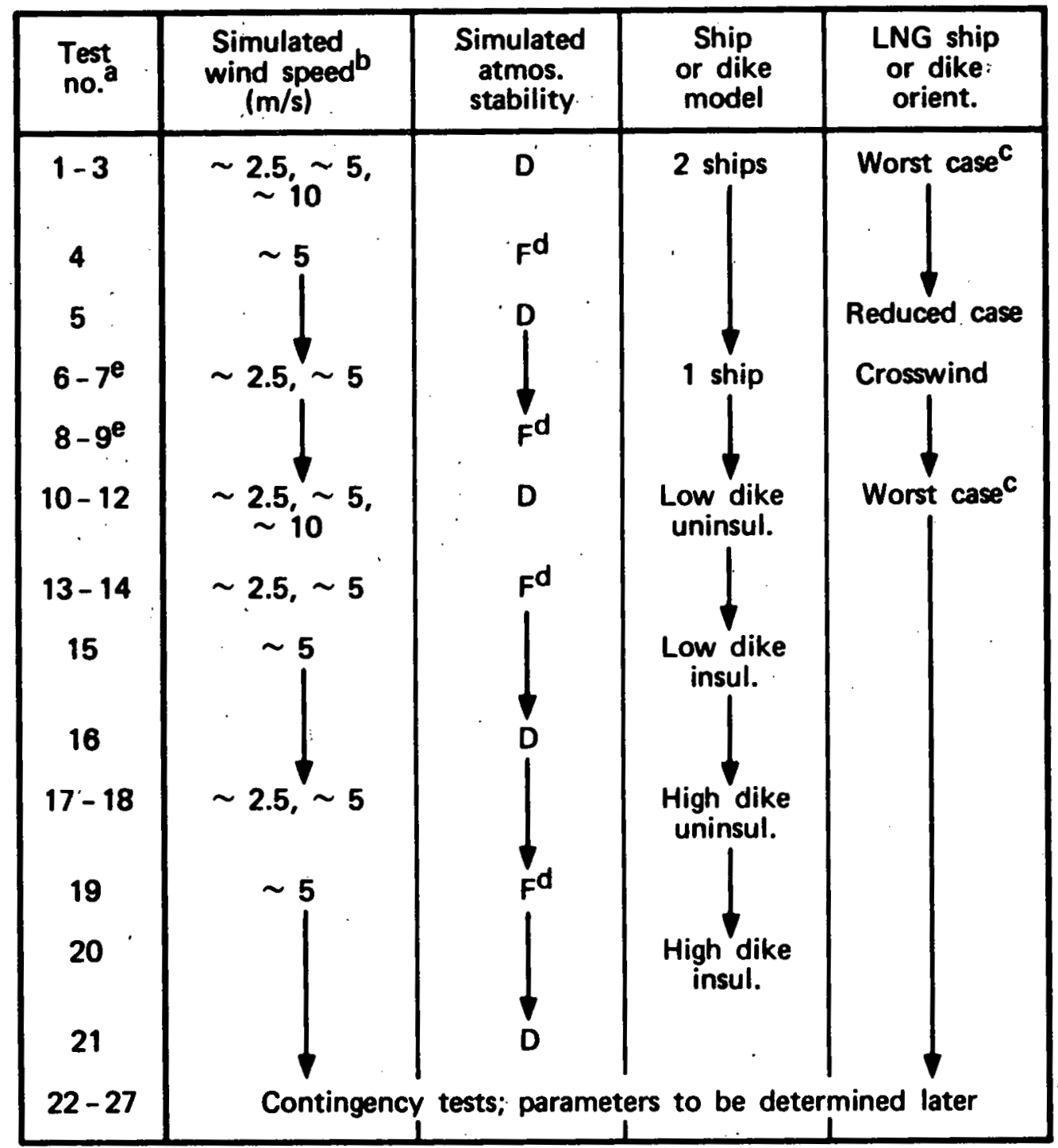

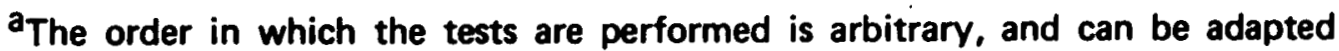
to the prevailing meteorological and logistic conditions.

${ }^{b}$ To get the actual wind speed in the field, divide by 2.0 for tests 1-9 and by 1.8 for tests 10-21. These speeds may be modified, depending upon the results of previous tests and analyses.

COrientation that gives the longest LFL distance.

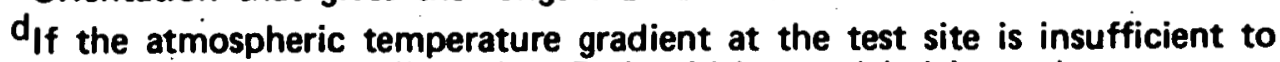
model a class F stability, class E should be modeled instead.

esmall spills to simulate a line break. The test site should include a model of a cliff shoreline. 
TABLE 6-6. RECOMMENDED INSTRUMENTATION FOR THE FIELD TESTS OF LNG VAPOR DISPERSION

70 TSI dual-film vapor' concentration sensors

20 infrared vapor-component sensors

20 thermocouples in the vapor-air cloud

60 grab bottles to sample cloud composition

7 three-component hot-wire anemometers

4 wind bi-vanes

2 hygrometers

10 thermocouples at different heights upwind of the release (some connected to measure temperature differences)

20 thermocouples or thermistors buried in the soil below the vapor cloud

2 LNG spill-rate sensors

2 LNG samples prior to spill (for quantitative analysis.).

1 solar radiometer

4 movie cameras, low-speed color; one in aircraft

3 fast movie cameras, half-submerged in the water or dike floor, to observe the LNG pool spreading

100 thermocouples to measure liquid pool spread and water temperature (water spills only)

4 ice-measurement instruments (water spills only)

4 water-wave sensors (water spills only)

4 LNG depth sensors (land spills only) 
tunnel tests, but more extensive. Since several different sensors for methane and for the heavier LNG components are currently under development (Ref. 6-19), revisions to the list of sensors should be made if better alternates become available. In addition to the instruments for measuring gas concentrations, temperatures and velocities (as in the wind tunnel), other instruments are also required for measuring the LNG spill rates, spreading, boiloff, ice formation, etc., as described in Section $\mathrm{V}$.

A research program for studying the vapor dispersion of LPG spills could make use of the same test site, spill tanks and equipment to conduct scaled tests similar to those recommended for ING. The instrumentation should also be the same, except that sensors that distinguish between the major components of LPG (propane and butane) are probably unnecessary because the detonation properties of these two hydrocarbons are quite similar (see Section IX):

f. Data interpretation and correlation--As explained earlier in this section, it is expected that the data taken on the wind tunnel and field tests will verify the use of Froude scaling to derive mean vapor concentration contours for the corresponding full-scale LNG spills. Although the tests may show moderate Reynolds number effects on the peak-to-mean concentration ratios, and possibly on the mean concentrations close to the ship or dike models in the wind tunnels (where the Reynolds numbers are not so high), empirical extrapolations for these parameters in full-scale situations will probably be sufficiently accurate for practical purposes.

However, many LNG spill scenarios of possible interest are not covered in the limited number of tests recommended here for the basic program. These include intermediate-size spills, spills at a slower rate, spills in dikes of intermediate height, vapor dispersion over land that is not flat, etc. If any specific 
case of particular importance arises, it could be added to the test program, or at least tested in the smaller wind tunnel. For some new cases, however, approximate answers can probably be deduced from the results of the tests already listed, provided that these results can be expressed in terms of a few dimensionless quantities involving the dominant physical parameters.

Such an approach was used in our correlation of previous data from LNG dispersion simulations in the colorado state University wind tunnel (Refs. 6-3, 6-4), shown in Figure 6-7. In this correlation the vapor concentration, $x$, and downwind distance, $x$, are normalized by the use of the total volumetric vapor-release rate, $Q$, and a buoyancy scale length, $\ell_{b}$. Physical arguments (Ref. 6-3) indicate that for a steady (constantrate) release the proper choice of this length is

$$
\ell_{b}=\frac{g\left(\rho_{\text {vap }} / \rho_{\text {air }}-1\right) Q}{u^{3}},
$$

where $g$ is the acceleration due to gravity, $\rho_{\text {air }}$ and $\rho_{\text {vap }}$ are the initial densities of the air and LNG vapor (or simulant), and $\mathrm{u}$ is the wind velocity.

Figure $6-7$ is similar to one previously published (p. 4-7 of Ref. 6-3) except that the factor $T_{v a p} / T_{\operatorname{mix}}$ has been added to the ordinate, where $T_{\text {vap }}$ is the initial temperature of the vapor and $T_{\operatorname{mix}}$ is the temperature of the vapor-air mixture at the point of interest. This factor puts the cold gas and warm heavy gas concentrations on equivalent scales (see Ref. 6-4). The plotted points are from tests using room temperature $\mathrm{CO}_{2}$ as an LNG vapor simulant, so that $\mathrm{T}_{\mathrm{Vap}} / \mathrm{T}_{\mathrm{mix}}=1$ for these points. However, the line representing the Battelle Columbus Laboratories (BCL) correlation is based on LNG field test data, mostly at concentrations near the LFL, where $\mathrm{T}_{\mathrm{vap}} / \mathrm{T}_{\operatorname{mix}}$ \& $112 / 288=0.4$. 


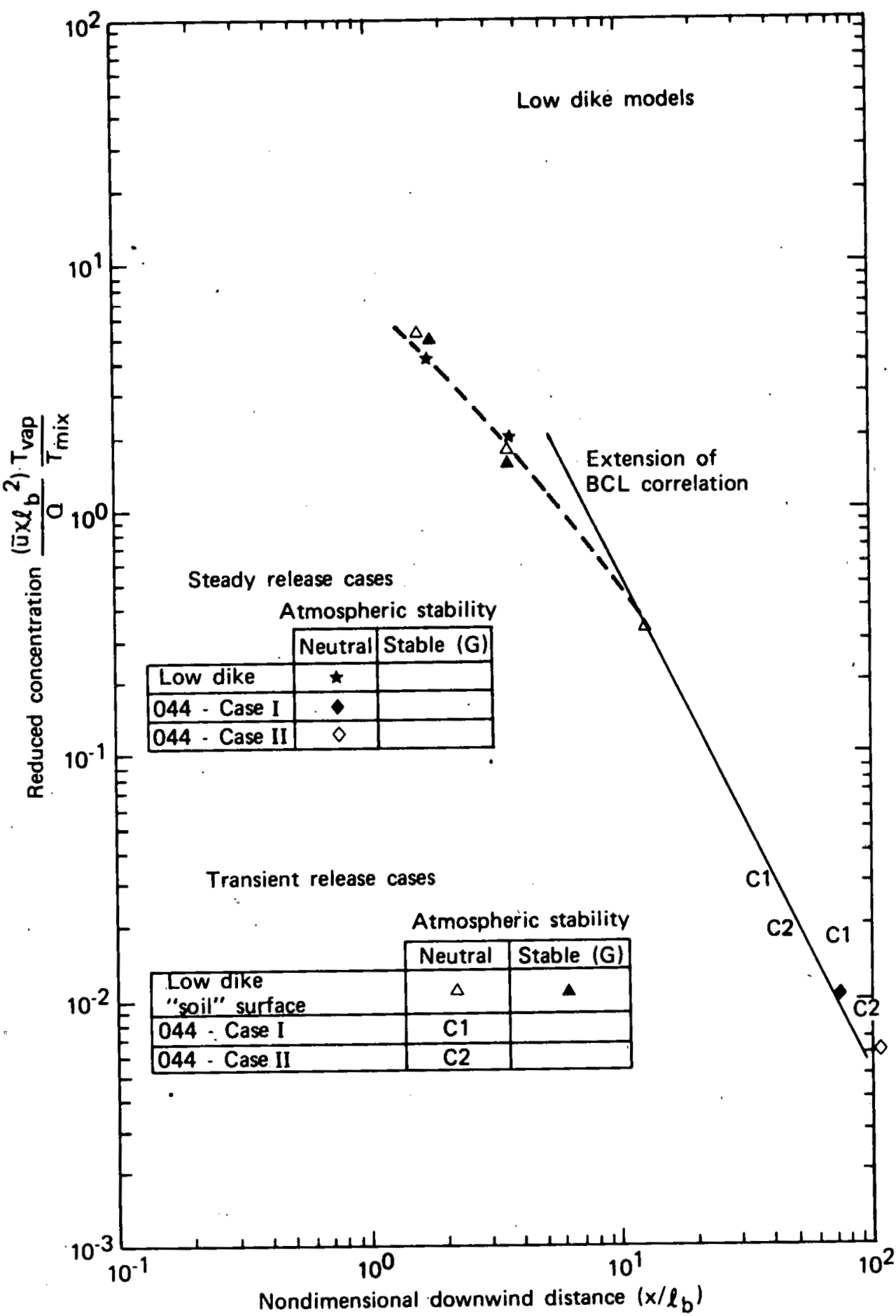

Figure 6-7. Reduced concentration data from wind tunnel tests of steady and transient vapor releases from low-dike models using $\mathrm{CO}_{2}$ as a simulation gas. (Ref. 6-3) 
All of the data shown on Figure 6-7 (including those from simulations of the 0.44 field test, and those backing the BCL correlation) were taken on tests where the dike walls were so low that they probably had little effect on the vapor dispersion, except possibly at small $\mathrm{x} / \mathrm{l}_{\mathrm{b}}$ values. In these dimensionless variables all of the results agree quite well, the reduced concentrations at a given nondimensional distance lying within 30 percent of the mean curve (except for one $\mathrm{Cl}$ point), while the distances to a given concentration lie within 20 percent. For $\mathrm{x} / \mathrm{l}_{\mathrm{b}} \gtrsim 10$ the mean curve also agrees with the straight-line BCL correlation (based on measurements at large $x / l_{b}$ ), while for smaller $x / l_{b}$ it falls somewhat lower. This deviation could be a basic property of dispersion at low $x / l_{b}$, or it could be due to the aerodynamic influence of the tank and dike structures in the close-in region.

There is no significant difference between the steady release data (where $Q$ was held constant) and the transient release data (where $Q$ was varied to simulate the decreasing boiloff rate after an actual spill), where the data are normalized by use of the maximum value of $Q$. This agreement is not surprising, because in the transient tests the vapor release rate was actually held constant during the first $120 \mathrm{~s}$ (ful1scale), since it was assumed to be limited by film boiling (see section V). This steady period is 4 to 10 times longer than the time required for the wind to blow across the dike length in these cases, presumably permitting the dispersion to approach a steady state.

Similar data for a high-dike model are shown in Figure 6-8. For $\mathrm{x} / \mathrm{l}_{\mathrm{b}} \gtrsim 10$ the steady release points fall slightly above the low-dike data, while for larger values of $\mathrm{x} / \mathrm{l}_{\mathrm{b}}$ they agree quite well, as one might expect at distances large compared to the dike dimensions. However, for the high dike the transient release data fall about a factor of 2 lower than the steady 


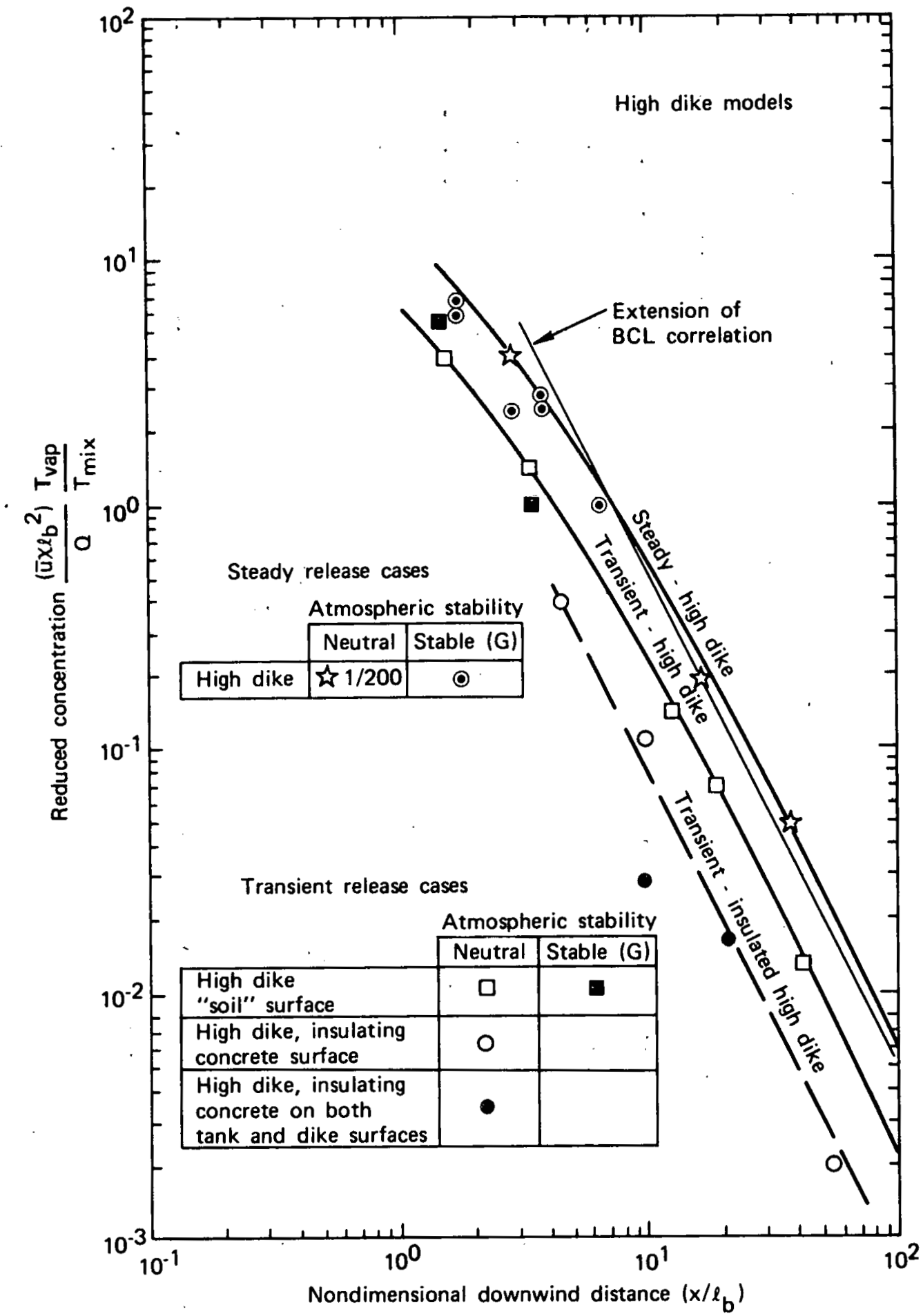

Figure 6:8. Reduced concentration data from wind tunnel tests of steady and transient vapor releases from high-dike models using $\mathrm{CO}_{2}$ as a simulation gas. (Ref. 6-3) 
release data. This difference, which was not observed on the low-dike measurements, is rather surprising, because the transient release rate for the high dike was nearly constant for 4 to 10 times the time required for the wind to blow across the dike diameter, just as in the low-dike tests. To be sure, as the heavy vapor spills over the top of the high dike and hits the ground it acquires a velocity. that causes it to spread outward initially more rapidly than the vapor from the low dike. However, it is difficult to understand why in steady releases the two dikes give essentially the same downwind vapor concentrations for $\mathrm{x} / \mathrm{l}_{\mathrm{b}} \succsim 10$, while in similar transient releases they differ by a factor of 2 .

Figure 6-8 also shows data (open circles) from tests simulating spills in a high dike with insulated walls and floor. These transient release data fall a factor of 2 to 3 below the transient: release data for the uninsulated high dike. However, most of this difference is due to normalizing the data by use of the peak rate at which the vapor was. reieased at the bottom of the dike model. Due to the low and rapidly decreasing rate used for the insulated-dike simulation, by the time the vapor filled the dike and spilled over into the air, the release rate was down to half its peak value. Correction for this factor moves the transient data for the insulated dike close to that for the uninsulated dike, but still leaves the discrepancy between all the high-dike transient data and the steady high-dike and steady and transient low-dike data.

Except for this discrepancy, the past data when plotted in this dimensionless form give a universal curve for steady or slowly varying releases at $x / l_{b} z 10$, and two fairly close curves for smaller values of $x / l_{b}$ ' between which one might interpolate for a dike of intermediate height, for example.

It would obviously be desirable to derive similar general dimensionless relations from the data of the wind tunnel and 
field tests recommended earlier in this section. However, this is likely to be more difficult. A large water spill in a low wind probably gives a vapor cloud that is closer to a "puff" than to a steady plume. For such puffs only the vapor volume, $v_{\text {vap' }}$ and not its initial shape may matter, so dimensional analysis suggests a buoyancy scale length

$$
\ell_{b}=\frac{g\left(\rho_{v a p} / \rho_{a i r}-1\right) v_{v a p}^{2 / 3}}{u^{2}}
$$

However, at moderately high wind speeds the vapor cloud from even a large, rapid spill on water may become stretched out into a plume, so that the definition of $\ell_{b}$ given earlier may be more appropriate. In the recommended water tests only $u$ is varied and not $V_{v a p}$ ' except for the much smaller "linebreak" tests, which are not really comparable. A plot of reduced concentrations versus normalized distance using this limited data base may give the illusion that dispersion from rapid water spills can be characterized by a single parameter, while actually a second parameter related to the puff/plume transition may be equally important.

Similar problems arise for the dike spill simulations, many of which probably lie in the transition region between the puff and the plume regions. However, with the help of the theoretical analyses described later, it may be possible to make some useful correlations of the test data (besides the simple Froude scaling discussed earlier).

The same statement holds for correlations of the data that would be taken in wind tunnel and field tests of LPG vapor dispersion, if a research program on LPG spills were initiated.

g. Extended experimental effort--If a larger research program is desired to give greater confidence in the results 
and to obtain answers for a greater variety of spill conditions, a number of additional wind tunnel and field tests should be added to the program. Some of these would be repetitions of the tests already listed to check the reproducibility of the measurements: In other tests the size and rate of the spill would be varied. Smaller and slower spills, though of less public concern, are not as improbable as the massive spills discussed above. Tests in which the land topography is varied would provide data useful in evaluating specific storage sites. Tests of a greater variety of dike designs should also be considered.

\section{MATHEMATIC MODELING PROGRAM}

a. General considerations--A simple analytic model of LNG vapor dispersion, such as the Germeles-Drake model (Ref. 6-5), can be useful in gaining understanding of the relevant physical processes and in making rough estimates of the quantitative behavior. However, we do not believe that the results of such models are sufficiently trustworthy or accurate for guiding important safety decisions, unless they are tested and calibrated by comparison with a more complete model. For the latter we recommend a time-dependent 3-D hydrocode.

Several 3-D Eulerian finite-difference codes exist for solving the turbulent Navier-Stokes equations including species diffusion. There are, however, three potential problem areas when applying these codes to vapor-cloud dispersion:

- Modeling of the turbulence.

- Numerical dirfusion effects.

- Modeling of the vorticity produced when the wind blows over ships, tanks, dikes, sharp terrain features, etc.

In most of the past turbulence modeling, simple eddy viscosities have been used. These do not inherently include buoyancy 
effects, so they cannot be relied on for calculating LNG vapor dispersion. Instead, a second-order closure model for turbulence is recommended. The two-equation $k-\varepsilon$ model (Refs. 6-20 to 6-22), wherein transport, generation by buoyant forces, and dissipation of turbulence is taken into account in a more realistic manner than in eddy viscosity models, can be employed with only a modest increase in computing cost. " When calibrated, the simple two-equation methods can probably give an adequate description of the turbulent transport of the mean concentration of the methane vapor. Probably the large-scale turbulence can also be reasonably predicted by these methods, but subgrid turbulence is not modeled. An accurate description of the fluctuations in methane concentration arising from the turbulent flow fluctuations is essential for predictions of cloud combustion and explosion phenomena. Normal finite-difference schemes, however, cannot calculate fluctuations with wavelengths shorter than a few cell lengths. Due to computer limitations the computational cells will necessarily be large (the SIGMET code has typically used 200-m cells in the horizontal plane for water spills), and consequently small-scale turbulent fluctuations cannot be treated. These turbulent fluctuations arise primarily from the coherent vortex structures set up by the shear interaction between the vapor cloud and the air (see Reference 6-26 for an experimental investigation of coherent

* More complex second-order closure schemes have been developed by the Aeronautical Research Associates, Princeton. Such schemes were successfully used in 2-D codes to calculate atmospheric boundary layers (Ref. 6-23) and their stability characteristics (Ref. 6-24), shear layer entrainment, and atmospheric dispersal of pollutants (Ref. 6-25). The principal drawbacks of these codes are that extension to $3-D$ would require major code reformulation. (telephone conversation with $W$. L. Lewellen, May 10, 1979), and the cost of solving the large. number of partial differential equations (23 for 3-D) for the second-order turbulence correlations is large. 
vortices). Based on expected cloud heights, there can be five to ten such vortices across the horizontal dimension of a 200-m computational cell. To predict these fluctuations mathematically for the entire flow field, a more direct modeling of vorticity is required. One such approach is Chorin's Random Vortex Method (RVM) (Ref. 6-27). Ashurst has used RVM to predict large-scale vortex motion in shear regions successfully (Ref. 6-28). These turbulent structures can also be studied in 2-D with an adaptive Lagrangian triangular grid method recently developed at the Naval Research Laboratory (Ref. 6-29). Such a method has been applied successfully to the 2-D Rayleigh-Taylor instability problem, as shown in Figure 6-9 (Ref. 6-30). Unfortunately, extension of Lagrangian codes to handle 3-D turbulent diffusion is a major unsolved problem, so only an Eulerian approach is practical at present.

A problem frequently encountered with Eulerian finite difference codes is that of numerical diffusion, caused both by numerical dissipation and phase errors of the difference operator for the convection terms. Of course, one desires to keep numerical diffusion small compared to molecular and turbulent diffusion. Numerical diffusion effects can be disastrous when calculating peaked waves, as demonstrated by Long and Pepper (Ref. 6-3l); a "hill" of concentration $C=1$ at the center whose diameter spanned 4 mesh spaces was passively advected in a circular motion through a 33 by 33 Eulerian mesh without molecular or turbulent diffusion. As shown in Figure 6-10; after the "hill" is translated one revolution around the mesh, some computational schemes diffused the concentration peak down to only 7 percent of its original value! (Physically, the peak concentration would have remained unity.) If such numerical diffusion is a problem for a given code, at least two techniques are available for its reduction: 

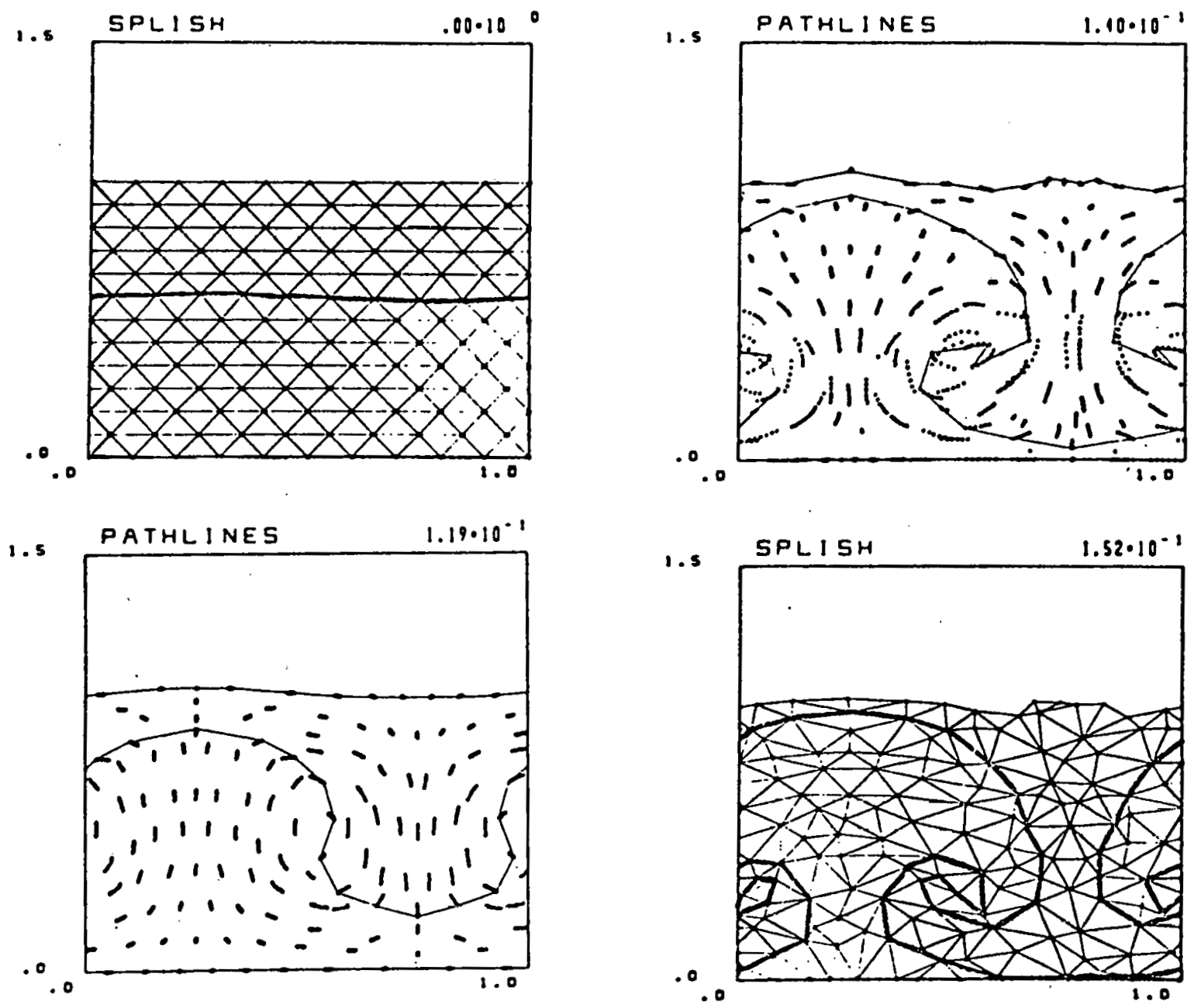

Figure 6-9. A Lagrangian Rayleigh-Taylor calculation. The heavier upper layer collapses generating vor$t i c e s$ at $t=0.119 . \mathrm{s}$. At $t=0.140 \mathrm{~s}$ the upper fluid has almost reached the bottom of the container and the vortices begin to mix the fluid layers. The vortices continue to roll-up at $t=0.152$ as the heavier fluid breaks over a bubble of lighter fluid. The lighter fluid is now multiply-connected since the heavier fluid has touched the bottom. The interface has been manually darkened for contrast. (Ref. 6-3.0) 


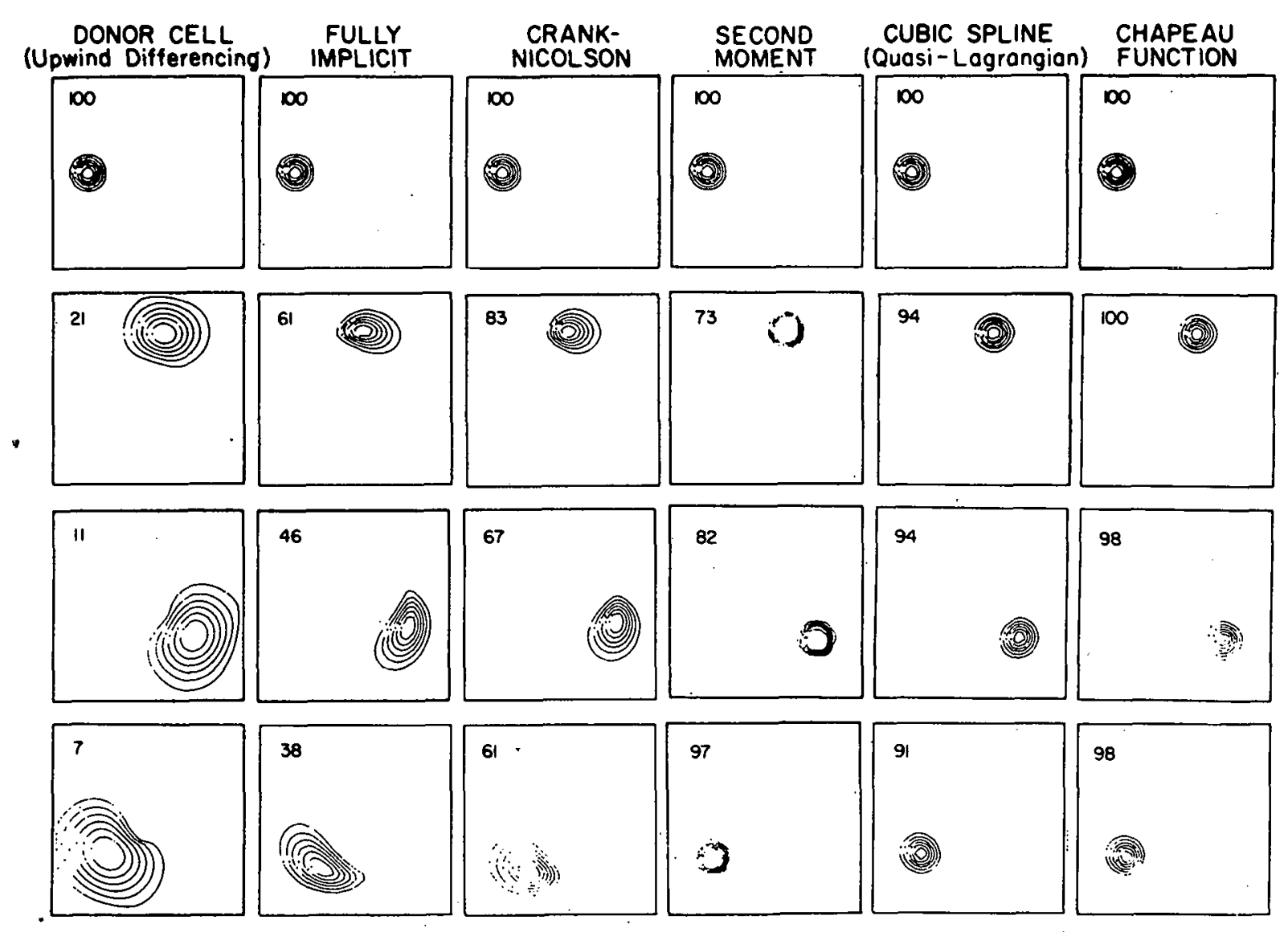

TWO-DIMENSIONAL CONTOURS, NUMBERS DENOTE MAXIMUM VALUES

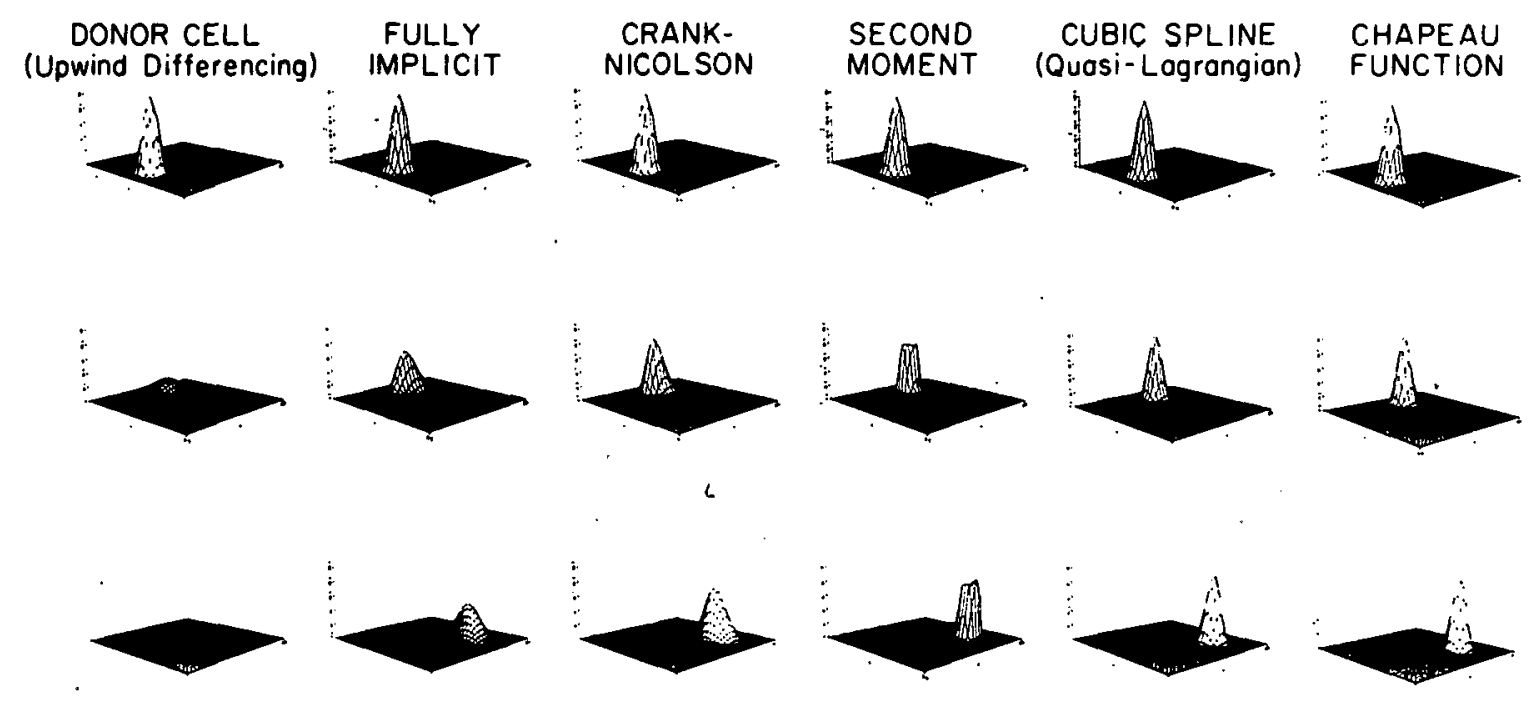

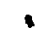
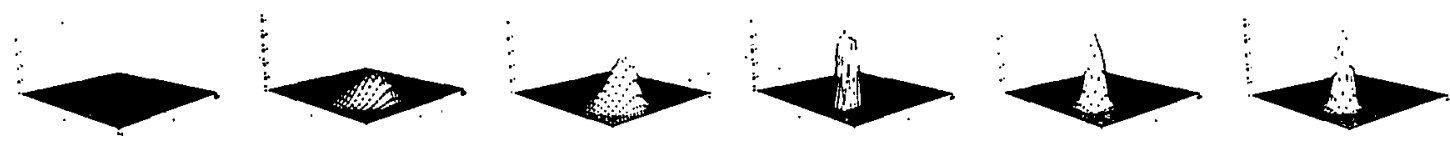

Figure 6-10. Examples of numerical diffusion errors for several Eulerian integration schemes for the advection of a peaked wave (Ref. 6-31) 
- J. Boris' Flux-Corrected Transport (FCT) technique (Refs. 6-32 to 6-35)..

- The Galerkin Finite-Element Method (FEM) (Ref. 6-36).

The FCT technique has recently been extended to multidimensions by zalesak (Ref. 6-35) and can be adapted to many existing finite-difference algorithms. The FEM approach would require changing the basic difference scheme. A Galerkin FEM . code has been used for atmospheric pollution studies (Ref. 6-36).

A final area of concern is the ability of the hydrocode to calculate and transport the vorticity produced when the wind blows over ships, dikes, etc. Due to computer limitations it may be impractical. to zone the relevant regions sufficiently fine to calculate the vortex street shed by such structures. Past wind-tunnel tests (Refs. 6-3, 6-4) suggest that this vorticity could be significant for spills from land-based storage tanks. For large ship spills it is probably insignificant. If and when future wind-tunnel tests show it to be of major importance, the entire numerical approach may have to be modified if mathematical models are to be pursued further for these cases. At least two solutions appear possible:

- If the only important sources of vorticity are near the spill point, calculate that region with a finely zoned mesh; then use the flux from that calculation as input for a downwind dispersion calculation.

- If that fails, model the vorticity more directly by using RVM or another suitable method.

The RVM method has been used to calculate the wake of circular cylinders (Ref. 6-27) and spheres (Ref. 6-37); it has not yet been applied to the two-fluid case with density differences characteristic of LNG vapor dispersion. 
The mathematical models recommended above would be equally useful for studies of LPG vapor dispersion. Practically the same code development and evaluation tasks (listed below) are required for such a study. However, if the codes were first developed and checked for LNG dispersion, only a little further checking with LPG measurements would be required.

b. Recommended basic effort--The initial goal of the mathematical modeling program outlined in this subsection is to select the most appropriate existing 3-D hydrocode that includes turbulent mixing and use it to make preliminary vapor dispersion calculations to guide the wind tunnel and field test planning. The final goal is to develop and prove a capability for calculating, in.3-D with time dependence, the mean vapor concentrations from a full-scale LNG spill. A secondary goal is to obtain some information on concentration fluctuations, if possible with current mathematical models. The method recommended for achieving these goals is to carry out the ten tasks presented and justified in Tables 6-7 to 6-18. These tables are self-explanatory.

c. Extended mathematical effort--If a larger research program is desired to give greater confidence in the results and to obtain answers for a greater variety of spill conditions, a number of additional vapor dispersion calculations should be added to the program. Some of these would explore alternative mathematical approaches and codes to a greater extent than proposed in the basic effort. Other added calculations would model the additional wind tunnel and field tests described above under the extended experimental effort. These tests are designed to explore a greater range of spill sizes and rates, dike designs, land topographies, etc. 
TABLE 6-7. MATHEMATICAL MODELING TASK 1-PRELIMINARY CODE EVALUATION

AND IMPROVEMENT.

\section{OBJECTIVES}

- Identify an existing 3-D Navier-Stokes code suitable for performing a preliminary sensitivity analysis (and possibly the follow-on work) on vapor dispersion.

- Make simple improvements to the code, where appropriate. APPROACH

- Evaluate the numerical diffusion errors of existing codes (e.g., SIGMET, COM3, etc.) by running a pure advection problem. This can be accomplished by placing a squat cylinder of pure LNG vapor in the mesh and computationally advecting it to a distance comparable to the maximum expected LFL distance, with turbulent diffusion turned off.

- Review and evaluate codes for turbulent mixing models, heat transfer models and cost effectiveness.

- Select a code which has acceptable numerical diffusion properties, turbulent mixing models, etc.

- If expedient, perform simple code improvements such as adding the effects of humidity, increasing the versatility of modeling initial and boundary conditions, and improving the turbulent mixing and heat-transfer models.

\section{JUSTIFICATION}

- The magnitude and relative importance of numerical diffusion is unknown for most codes currently in use on this problem.

- Simple code improvements will be useful for Task 2. REQUIRED INPUT

- Detailed information on candidate codes to be evaluated.

\section{EXPECTED OUTPUT}

- Identification of the most appropriate code for preliminary sensitivity analysis.

- Possible incorporation of simple improvements.

- Identification of code deficiencies requiring long-term improvements.

ANT ICIPATED DURATION

- Three months. 
TABLE 6-8. MATHEMATICAL MODELING TASK 2--

PRELIMINARY SENSITIVITY ANALYSIS.

\section{OBJECTIVES}

- Provide early information concerning the sensitivity of vapor dispersion to the physical parameters of the problem to be used as guidance in designing wind tunnel and field tests.

- Provide sensitivity information to be used in prioritizing hydrocode development.

\section{APPROACH}

- With the hydrocode selected in Task 1, perform the series of parametric sensitivity calculations indicated in Tables 6-9 and 6-10. (Because of code limitations, the aerodynamic effects of tank, dike or ship are not included.) These calculations will indicate the effects of variations in wind speed, vapor release rate, and surface heat transfer on the vapor cloud dispersion. *

- Also use the analytical model of Germeles and Drake (Ref. 6-5) to investigate these effects. $\star \star$

\section{JUSTIFICATION}

- Early technical guidance is needed to design the vapor dispersion tests in the wind tunnel and field.

\section{REQUIRED INPUT}

- Preliminary vapor-release model. EXPECTED OUTPUT

- Preliminary estimates of the wind velocity for maximum LFL distances.

*Calculations of a.small "line-break" spill are omitted from this task because the vapor dispersion in that case is expected to be strongly perturbed by the ship and dock structures. Similarly omitted are calculations for spills in uninsulated dikes, where the reduced boiloff rate probably limits the flammable cloud to the region influenced by the dike and tank.

**Prior to use of this model, we recommend changing the time of switching from gravity spreading to atmospheric diffusion to the time when the gravity-spreading velocity equals the turbulent rms velocity at half the vapor cloud height. 
TABLE 6-8. CONCLUDED

- Preliminary indication of the effect of heat transfer on vapor dispersion (this affects the choice of floor material for wind-tunnel tests and soil material for land field tests).

- Preliminary indication of the importance of the humidity (this affects whether to require humidity control in the wind-tunnel tests).

- Preliminary indication of the importance of atmospheric stability (this affects wind-tunnel and field-test planning).

- Preliminary indication of the importance of vapor-release variations.

ANTICIPATED DURATION

- Six months. 
TABLE 6-9. RECOMMENDED PRELIMINARY WATER SPILL CALCULATIONS $\left(25,000 \mathrm{M}^{3}\right.$ SPILL, NO SHIPS)

\begin{tabular}{|c|c|c|c|c|c|c|}
\hline $\begin{array}{l}\text { Calc. } \\
\text { no. }\end{array}$ & $\begin{array}{l}\text { Wind speed } \\
(\mathrm{m} / \mathrm{s})\end{array}$ & $\begin{array}{l}\text { Atmos. } \\
\text { stabil. }\end{array}$ & Humidity & $\begin{array}{l}\text { LNG } \\
\text { spread } \\
\text { rate }\end{array}$ & $\begin{array}{l}\text { Boiloff } \\
\text { rate per } \\
\text { unit area }\end{array}$ & $\begin{array}{l}\text { Surface-to- } \\
\text { vapor heat } \\
\text { transfer }\end{array}$ \\
\hline $1-2$ & $0,2.5$ & D & Low & Nominal & Nominal & Nominal \\
\hline $3-5$ & $5,10,20$ & & & & & \\
\hline 6 & a & & & & & Zero \\
\hline 7 & & & 1 & & & $\begin{array}{c}\text { Half } \\
\text { nominal }\end{array}$ \\
\hline 8 & & & & & & $\begin{array}{c}\text { Twice } \\
\text { nominal }\end{array}$ \\
\hline 9 & & & & & $\begin{array}{c}\text { Half } \\
\text { nominal }\end{array}$ & Nominal \\
\hline 10 & & & & & $\begin{array}{c}\text { Twice } \\
\text { nominal }\end{array}$ & \\
\hline 11 & & & & $\begin{array}{c}1.5 \times \\
\text { nominal }\end{array}$ & Nominal & \\
\hline 12 & & & & $\begin{array}{l}\text { Const. } \\
\text { diam. }\end{array}$ & & \\
\hline $13-14$ & $5,10^{b}$ & & High & Nominal & & \\
\hline $15-16$ & & $\mathbf{F}$ & & & & \\
\hline $17-18$ & & & Low & & & \\
\hline $\begin{array}{c}19-21 \\
!\end{array}$ & \multicolumn{6}{|c|}{ Contingency calculations; parameters to be determined later } \\
\hline
\end{tabular}

aWhichever wind speed in Calculations No. 1-5 gives the maximum flammable region.

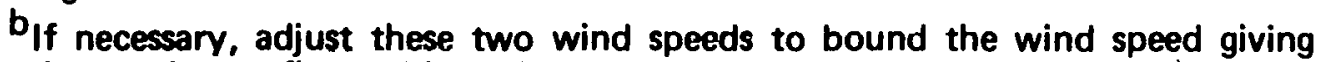
the maximum flammable region. 
TABLE 6-10. RECOMMENDED PRELIMINARY DIKE SPILL CALCULATIONS (NO DIKE WALLS OR TANK STRUCTURE)

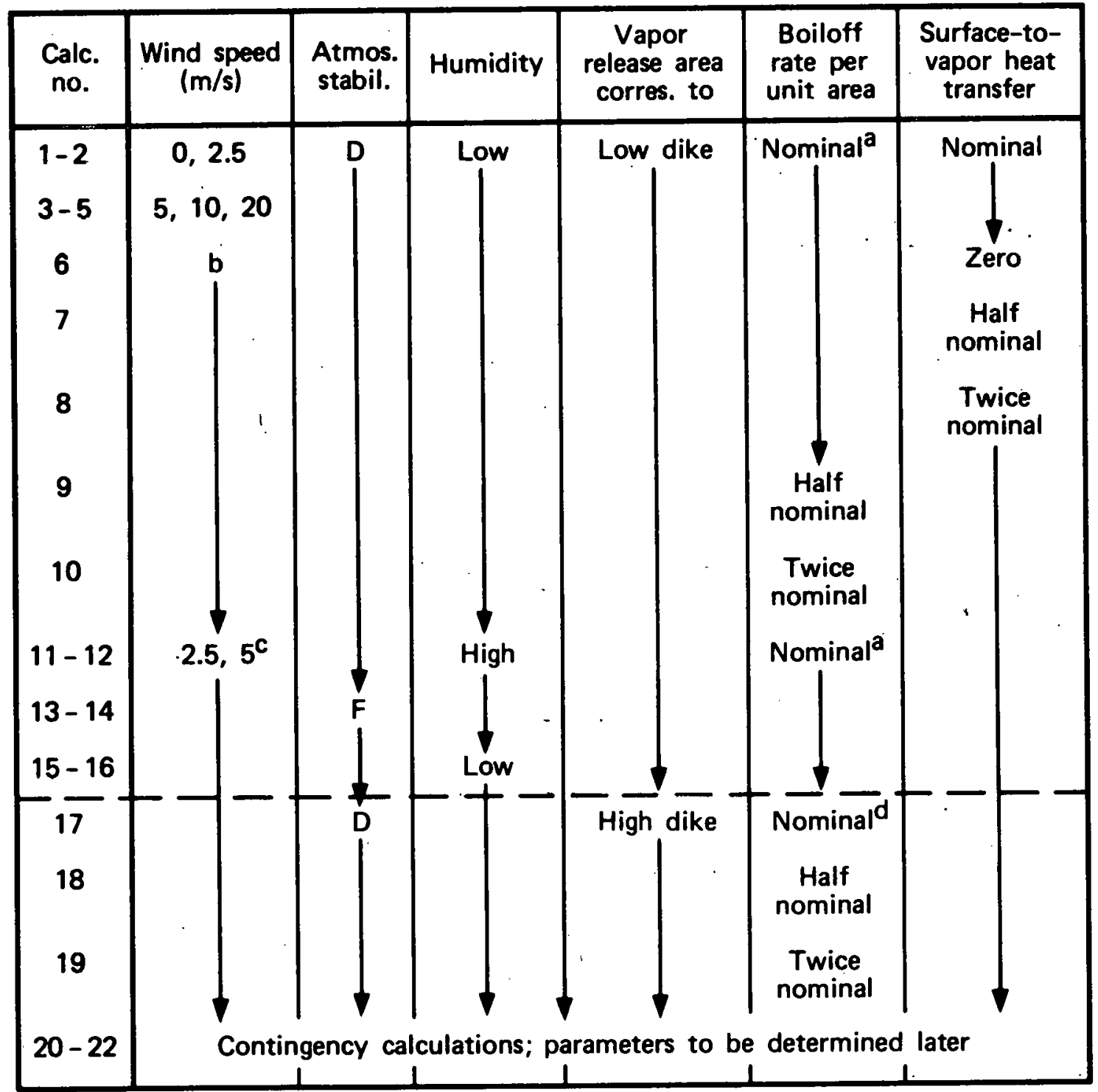

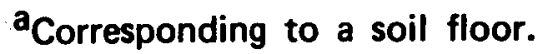

bWhichever wind speed in calculations nos. 1 -5 gives the maximum flammable region.

$c_{\text {If necessary, adjust these two wind speeds to bound the wind speed giving }}$ the maximum flammable region.

${ }^{d}$ Corresponding to a concrete floor and dike wall (wall included in boiloff calculation but not in vapor dispersion calculation). 
TABLE 6-11. MATHEMATICAL MODELING TASK 3-NUMERICAL DIFFUSION SUPPRESSION

(IF REQUIRED) .

OBJECTIVE

- Reduce code numerical diffusion to levels small compared to turbulent diffusion.

APPROACH

- Incorporate FCT method or some other technique to minimize numerical diffusion.

- Test code by running pure advection cases of 2-D and 3-D "pills" of initially pure vapor.

JUSTIF ICATION

- If too large, numerical diffusion can introduce serious errors in the description of the vapor-cloud dispersion.

REQUIRED INPUT

- Demonstrated need for numerical diffusion suppression. (This task would be performed only iff the results of Mathematical Modeling Task 1 so indicated.)

EXPECTED OUTPUT

- Hydrocode with negligible numerical diffusion.

ANTICIPATED DURATION

- Six to twelve months, depending on code chosen. 
TABLE 6-12. DISPERSION MODELING TASK 4-TURBULENT MIXING TESTS.

\section{OBJECTIVE}

- Provide fundamental turbulent mixing data for code devel opment.

APPROACH

- Using the 1.8-m meteorological wind tunnel at Colorado State University, or the equivalent, run line-source tests with a heavy vapor using variable and constant vapor-release rates for D- and F-atmospheric stabilities and various wind speeds.

- Measure the transient concentration field with about 10 dualfilm gages and the vapor-cloud entrainment with video cameras.

\section{JUSTIFICATION}

- Current turbulence models were developed for flows with balances of physical mixing mechanisms different from the LNG situation. Turbulence models to be used in upgraded LNG and LPG vapor dispersion calculations must be verified for a spreading gravity current in the simplest geometry.

REQUIRED INPUT

- Appropriate vapor release rates.

- Wind tunnel sheer layer description.

EXPECTED OUTPUT

- Data for building a turbulence model appropriate for calculating LNG vapor dispersion.

ANTICIPATED DURATION

- Six months. 
TABLE 6-13. MATHEMATICAL MODELING TASK 5--

TURBULENT MIXING MODEL IMPROVEMENTS

OBJECTIIVE

- Improve the turbulent mixing in the chosen hydrocode.

APPROACH

- Improve the turbulence modeling by incorporating the twoequation algebraic stress model, or some other model as appropriate, into the chosen hydrocode:

- Use recognized experts in turbulence modeling of buoyant shear flows and atmospheric boundary layers to help guide the modeling development.

- Numerically simulate the line-source experiments (Task 4).

- Modify modeling constants and iterate.

JUSTIFICATION

- Turbulent diffusion will control the later stages of cloud dispersion.

- Preliminary comparisons of code and wind tunnel data will probably indicate that the current turbulent mixing models are inadequate.

- The two-equation stress model gives not only the turbulent diffusion, but also the second-order turbulent correlations. REQUIRED INPUT

- Data from turbulent mixing tests (Task 4). EXPECTED OUTPUT

- An adequate turbulence model.

ANTICIPATED DURATION

- Nine months. 
TABLE 6-14. MATHEMATICAL MODELING TASK 6-NUMERICAL SIMULATION OF SMALLSCALE WIND TUNNEL TESTS

\section{OBJECTIVE}

- Provide prel iminary code evaluation and guidance for further development, using the small wind tunnel test data.

\section{APPROACH}

- Numerically simulate the key experiments in the smaller wind tunnel, compare the results with data, and iterate.

- If tests indicate that ships or tanks and dikes affect the vapor dispersion, perform some calculations with simple representations of these structures to determine whether the code can adequately model these effects.

\section{JUSTIFICATION}

- Preliminary code comparisons with data from scaled experi- . ments will be extremely useful for guiding the numerical code development work.

\section{REQUIRED INPUT}

- Data from smal1-scale wind tunnel tests:

EXPECTED OUTPUT

- Preliminary predictions of full-scale vapor dispersion.

- Requirement for further code development work on structuregenerated vorticity and/or turbulence modeling.

- Input to planning of large wind tunnel and field-tests. ANTICIPATED .DURATION

- Six to nine months. 
TABLE 6-15. MATHEMATICAL MODELING TASK 7-NUMERICAL SIMULATION OF LARGESCALE WIND TUNNEL TESTS

\section{OBJECTIVE}

- Verify the computer code capabilities for predicting the LNG vapor-cloud dispersion from large spills within the stated goals.

APPROACH

- Numericaliy simulate the key experiments in the large wind tunne1, pre- and post-test, compare with test data, and iterate if necessary.

\section{JUSTIFICATION}

- The use of an unverified code to predict full-scale LNG vapor-cloud dispersion produces results of unknown accuracy and confidence--codes must be verified with accurate and relevant test data.

REQUIRED INPUT

- Data from large-scale wind tunnel tests.

EXPECTED OUTPUT

- Verified code, or requirements for further code improvement.

ANTICIPATED. DURATION

- Six months. 
TABLE 6-16. MATHEMATICAL MODELING TASK 8--

NUMERICAL SIMULATION OF FIELD TESTS

\section{OBJECTIVE}

- Verify the computer code capabilities for predicitng the LNG vapor-cloud dispersion from large spills within the stated goals:

APPROACH

- Numerically simulate the field-test experiments pre- and post-test, compare with test data, and iterate if necessary.

\section{JUSTIFICATION}

- The use of an unverified code to predict full-scale LNG vapor-cloud dispersion produces results of unknown accuracy and confidence--codes must be verified with relevant test data.

- Pre-test calculations can be useful in setting instrument ranges and locations.

REQUIRED INPUT

- Data from field tests.

EXPECTED OUTPUT

- Verified code (for the spill conditions tested), or requirement for future code improvement.

ANTICIPATED DURATION

- Four months. 
TABLE 6-17. MATHEMATICAL MODELING TASK 9-FINAL NUMERICAL PREDICTIONS OF LNG VAPOR-CLOUD DISPERSION

\section{OBJECTIVE}

- Numerical prediction of the dispersion of an LNG vapor. cloud for generic spills from ships and from land facilities. APPROACH

- Using the hydrocode validated during this program, perform calculations to simulate the dispersion of LNG vapor clouds formed by a range of spill sizes and rates from generic ships and land facilities for various atmospheric conditions and terrains.

JUSTIFICATION

- Accurate predictions of LNG vapor clouds are required for the evaluation of fire and explosion hazards from LNG spills.

- Mathematical models can simulate full-scale spill conditions relatively inexpensively, without the limitations imposed by wind tunnel and field tests (smaller Reynolds numbers, boiloff and heat transfer scaling problems, etc.)

REQUIRED INPUT

- Verified mathematical model.

EXPECTED OUTPUT

- Credible predictions of LNG vapor-cloud dispersion. ANTICIPATED DURATION

- Three months. 
TABLE 6-18. MATHEMATICAL MODELING TASK 10-CODE DEVELOPMENT FOR MODELING COHERENT VORTICITY

OBJECTIVE

- Improvement of the mathematical modeling of coherent vorticity (generated either by surface structures or at the vapor/air interfaces) to improve predictions of both the mean and the fluctuating LNG vapor concentrations.

\section{APPROACH}

- Apply the existing RVM and Lagrangian triangular-grid codes, both of which are 2-D, to the line-source mixing tests of Task 4 and compare the results with the measurements.

- If these comparisons are encouraging, apply the same codes to the LNG dispersion cases tested in the wind tunnel and field, for times and places where the cloud is flat and the mixing essentially vertical, and compare with data.

- If justified by the above results and other considerations, extend one of these methods to the 3-D (a major undertaking).

- Evaluate the 3-D code by applying it to cases tested experimentally (including the vortices generated both at the vapor/air interface and by dikes, tanks, ships, etc.).

\section{JUSTIFICATION}

- Ordinary Eulerian 3-D codes do not adequately treat the coherent vorticity observed in model tests of vapor dispersion.

- Two existing non-Eulerian codes can treat coherent vorticity in 2-D; their application to the calculation of vapor dispersion from large LNG spills would be very useful, since the mixing is believed to be due primarily to nearly 2-D vortices ait the top of the flat cloud. Such calculations would give not only improved values of the mean vapor concentration, but also values for that part of the turbulent fluctuations due to coherent vortices (which may be the largest part).

- Extension of one of these codes to 3-D, though difficult, would permit inclusion of the vortices formed at the sides

s. of the vapor cloud and around the dike, tank, ship or other structures. These vortices probably affect the mixing, especially close to the structures. 
TABLE 6-18. CONCLUDED

REQUIRED INPUT

- Data from the line-source mixing tests (Task 4) and the wind tunnel and field tests (Tasks 6 to 8 ).

EXPECTED OUTPUT

- Improved mathematical modeling capabilịties.

ANT ICIPATED DURATION

- Nine months for the 2-D calculations; two years if extended to 3-D. 
6-1. LNG Safety Program, Interim Report on Phase II Work, (AGA Project IS-3-1), Battelle Columbus Laboratories, July 1,1974 .

6-2. Lind, C. D., and Whitson, J. C., "China Lake Spill Tests," Report L of Liquefied Gaseous Fuels Safety and Environmental Control Assessment Program: A Status Report, U.S. Dept. of EnergY, DOE/EV-0036, May 1979 .

6-3. Liquefied Natural Gas wind Tunnel Simulation and Instrumentation Assessments, $R \& D$ Associates, U.S. Dept. of EnergY, SAN/W1364-01, April 1978.

6-4. LNG Safety Program Final Report (AGA Project IS-128-1), $\mathrm{R} \& \mathrm{D}$ Associates, RDA-TR-603010-001, June 1979.

6-5. Germeles, A. E., and Drake, E. M., "Gravity Spreading and Atmospheric Dispersion of LNG Vapor Clouds," Proceedings of the Fourth International Symposium on Transportation of Hazardous Cargos by sea and Inland Waterway, Department of Transportation, U.S. Coast Guard Report USCG-D-24-76, October 1975.

6-6. Cox, R. A., and Roe, D. R., "A Model of the Dispersion of Dense Vapor Clouds," Loss Prevention and Safety in the Process Industries, Heidelberg, Germany, September 6-9, 1977.

6-7. LNG Terminal Risk Assessment Study for Point Conception, California, Science Applications, Inc., SAI-75-616-IJ, January 23, 1976.

6-8. Havens, J. A., A Description and Assessment of the SIGMET LNG Vapor Dispersion Model, University of Arkansas, USCG Report CG-M-3-79, February 1979.

6-9. Slater, D. H., et al., "Safety Issues in the Siting of LNG Terminals." Preprints of Conference Papers, GASTECH Houston, Gastech Ltd., Houston, Texas, November 13-16, 1979. 
6-10. Predictability of LNG Vapor Dispersion from Catastrophic Spills onto Water: An Assessment, Dept. of Transportation, U.S. Coast Guard, April 1977.

6-11. Fay, J. A., and Lewis, D. H., Jr., "The Inflammability and Dispersion of ING Vapor Clouds," Fourth International Symposium on Transport of Hazardous cargos by sea and Waterways, Jacksonville, Florida, October 1975.

6-12. Roshko, A., "Structure of Turbulent Shear Flows: A New Look," AIAA J., Vol. 14, No. 1.0, October 1976, pp. 13491357.

6-13. Thermal Radiation and overpressures from Instantaneous LNG Release into the Atmosphere - Phase II, TRW Systems; Report No. 08072-9, May 1969.

6-14. Turner, J. S., Buoyancy Effects in Fluids, Cambridge University Press, 1973.

6-15. Britter, R. E., and Simpson, J. E., "Experiments on the Dynamics of a Gravity Current Head," Journal of Fluid Mechanics, Vol. 88, Part 2, 1978, pp. 223-240.

6-16. Burgess, D. S., Murphy, J. N., and Zabetakis, M. G., Hazards of LNG Spillage in Marine Transportation, U.S. Bureau of Mines, SRC Report No. S-4105, 1970 (AD 705078).

6-17. Cermak, J. E., "Applications of Fluid Mechanics to Wind Engineering -- A Freeman Scholar Lecture," J. Fluids Eng., Vol. 97, 1975, pp. 9-38.

6-18. Van Stralen, S.J.D., Joosen, C.J.J., and Sluyter, W. M., "Film Boiling of Water and an Aqueous Binary Mixture," Int. J. Heat Mass Transfer, Vol. 15, 1972, pp. 2427-2445.

6-19. Koopman, R. P., et al., "A Review of the 1978 China Lake Liquefied Natural Gas Dispersion Experiments and Instrumentation: The Lawrence Livermore Laboratory Effort," Current Research on Methane Detection and Measurement, Gas Research Institute, Chícago, August 27, 1979, pp. 119160 .

6-20. Gibson, M. M., and Launder, B. E., "On the Calculation of Horizontal, Turbulent, Free Shear Flows under Gravitational Influence," ASME J. Heat Transfer, Vol. 98c, 1976, pp. 81-87. 


\section{REFERENCES FOR SECTION VI (CONT'D)}

6-21. Gibson, M. M., and Launder, B. E., "Ground Effects on Pressure Fluctuations in the Atmospheric Boundary Layer," J. Fluid Mech., Vol. 86, Part 3, 1978, pp. 491-511.

6-22. Launder, B. E., "On' the Effects of a Gravitational Field on the Turbulent Transport of Heat and Momentum," J. Fluid Mech., Vol. 67, Part 3, 1975, pp. 569-581.

6-23. Donaldson, C. P., "Construction of a Dynamic Model of the Production of Atmospheric Turbulence and the Dispersal of Atmospheric Pollutants," Workshop on Micrometeorology, D. A. Haugen (ed.), American Meteorological Society, 1973, Chapter 8, pp. 313-392.

6-24. Lewellen, W. S., "Use of Invariant Modeling," Handbook of Turbulence, Vol. I, W. Frost and R. H. Moulden (eds.), Plenum Publ., 1977, Ch. 9, pp. 237-280.

6-25. Lewellen, W. S., and Teske, M. E., "Prediction of Moninobukhov Similarity Functions from an Invariant Model of Turbulence," J.Atmos. Sci., Vol. 30, 1973, pp. 1340-1345.

6-26. Brown, G. L., and Roshko, A., "On Density Effects and Large Structure in Turbulent Mixing Layers," J. Fluid Mech., Vol. 64, Part 4, 1974, pp. 775-816.

6-27. Chorin, A. J., "Numerical study of a slightly Viscous Flow," J. Fluid Mech., Vol. 57, Part 4, 1973, pp. 785-796.

6-28. Ashurst, W. T., "Vortex simulation of a Model Turbulent Combustor," Seventh International Collogium on Gasdynamics of Explosions and Reactive Systems, August 1974 .

6-29. Fritts, M. J., and Boris, J. P., "The Lagrangian Solution of Transient Problems in Hydrodynamics Using a Triangular Mesh," J. Comp. Phys., Vol. 31, No. 2, May 1979, pp. 173215.

6-30. Fritts, M. J.., "Numerical Approximations on Distorted Lagrangian Grids," Proc. Third Int'l. Symposium on Computer Methods in Partial Differential Equations, Bethlehem, Penn., 1979. 


\section{REFERENCES FOR SECTION VI (CONT'D)}

6-3i. Long, P. E., and Pepper, D. W., "A Comparison of Six Numerical Schemes for Calculating the Advection Equation of Atmospheric Pollution," Third Symposium on Atmospheric Turbulence, Diffusion and Air Quality, Amer. Meteorol. Soc., Raleigh, N.C., October 19-22, 197.6, pp. 181-187.

6-32. Boris, J. P., and Book, D. L., "Flux-Corrected Transport. I, Shasta, a Fluid Transport Algorithm that Works," J. Comp. Phys., Vol. 11, 1973, pp. 38-69.

6-33. Book, D. I., Boris, J. P., and Hain, K., "Flux-Corrected Transport. II, Generalizations of the Method," J. Comp. Phys., Vol. 18, 1975, pp. 248-283.

6-34. Boris, J. P., and Book, D. I., "Flux-Corrected Transport. III, Minimal-Error FCT Algorithms," J. Comp. Phys., Vol. 20,

1976, pp. 397-431.

6-35. Zalesak, S. T., Fuliy Multi-Dimensional Flux-Corrected Transport, NRL Memorandum, Report 3716, May 1978 .

6-36. Giesho, P. M., Lee, R. I., and Sani, R. L., "Modeling the Planetary Boundary Layer Using the Galerkin Finite Difference Scheme," Third Symposium on Atmospheric Turbulence, Diffusion and Air Quality, Amer. Meteorol. Soc., Raleigh, N. C., october 19-22, 1976 .

6-37. Leonard, A., "Simulation of Three-Dimensional Separated Flows with Vortex Filaments," Fifth International Symposium on Numerical Methods in Fluid Dynamics, Twente University. of Technology, Enschede, Netherlands, June 28 to July 2 , 1976 (to appear in Lecture Notes in Physics, Springer-Verlag). 
VII. RECOMMENDED RESEARCH ON LNG POOL FIRES

\section{INTRODUCTION}

Accidental rupture of a storage tank might produce an LNG pool up to $200 \mathrm{~m}$ across (the size of the largest dikes), while rupture of a ship cargo compartment might produce a pool reachingsalmost a kilometer across. If ignition should occur immediately at the time of spill, pool fires of corresponding diameters would be formed, and the thermal radiation from their flames might cause damage or injury to distances of several pool diameters. For proper evaluation of such potential hazards, methods for predicting the maximum distance to a given level of radiant intensity with high confidence and reasonable accuracy are required. The desired accuracy depends upon the particular practical circumstances. In some situations an uncertainty of a factor of 2 in distance can be admissible because use of the upper bound causes little increase in the costs and difficulties of ING operations. In more constrained situations an accuracy of \pm 10 percent can be highly desiráble.

Current methods for predicting the radiation from LNG pool fires are based on a radiating-cylinder model, where the cylinder height and surface radiant power are semiempirical functions of the LNG pool diameter and boiloff rate, and the cylinder tilt is a function of these parameters and the wind speed (Refs. 7-1 to 7-3). The constants in these formulas have been evaluated primarily from data taken on diked fires 1.8 and $6 \mathrm{~m}$ in diameter (Ref. 7-1) and unconfined fires on water 9 to $17 \mathrm{~m}$ in diameter (Ref. 7-3).

Figure 7-1 illustrates one of the reasons for suspecting that these formulas, when applied to the much larger fires of practical concern, may give distances to a given radiation 


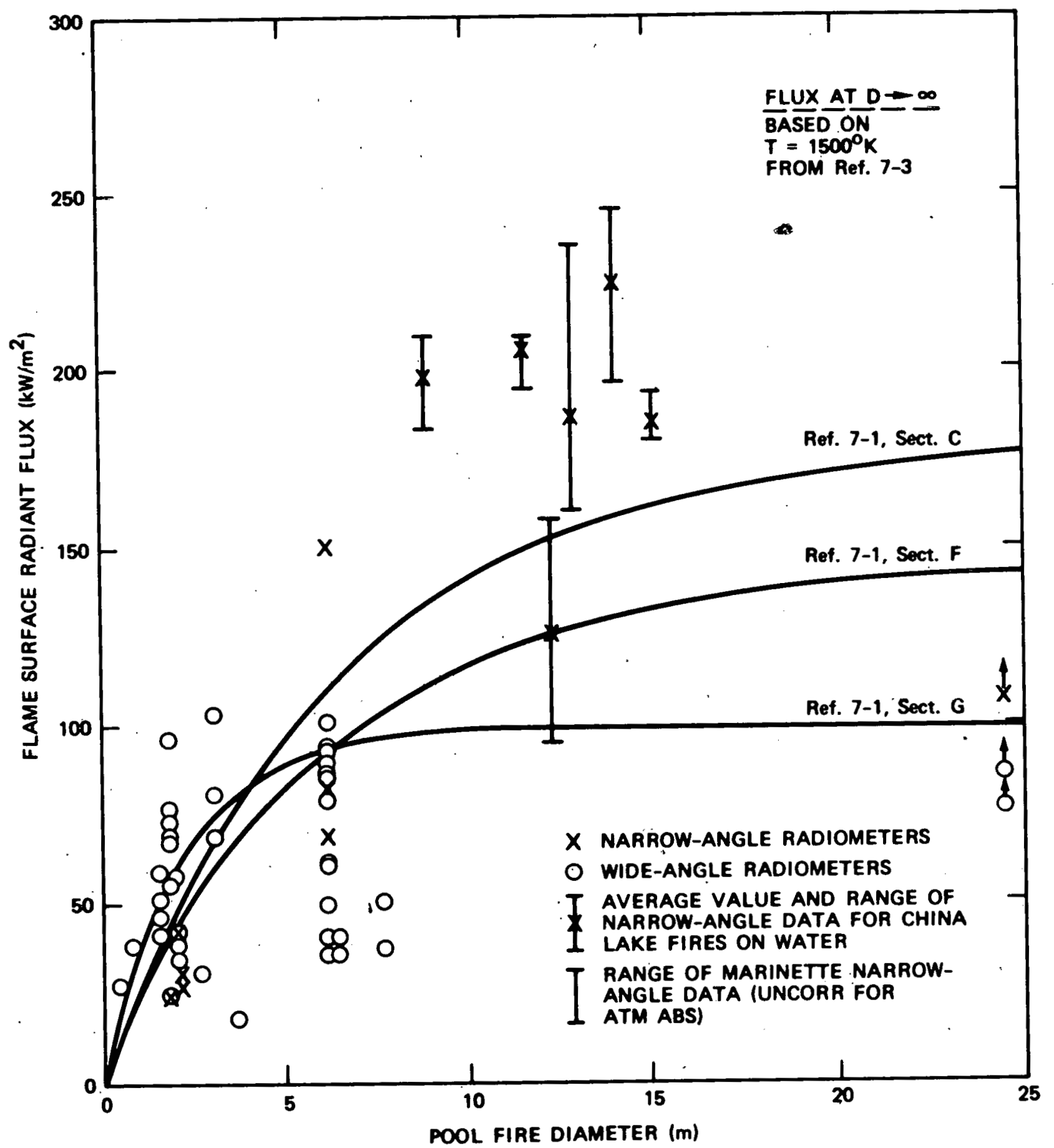

Figure 7-1. Experimental data and semiempirical fits to the surface-radiant fluxes of LNG pool fires. 
level that are in error by a factor of 1.5 or greater. It shows values for the surface radiant flux derived directly from narrow-angle radiometer data, or indirectly from wideangle radiometer data and photographic determinations of the flame area. (AIl of the values except the Marinette data were roughly corrected for atmospheric absorption, as discussed later.) Unfortunately, the only data on the largest test fire (24-m diameter) were taken before the period of strongest burning and so represent lower limits, as indicated by the arrows in the figure. (No surface-flux determinations were made on the irregularly shaped pool fire in Libya (Ref. 7-4), which was almost as large in cross-sectional area.)

Before 1979 only data from fires in soil dikes were available (Ref. 7-1); these data are shown by all of the points on Figure 7-1 except those designated by $\mathbb{\Psi}$. Using these data and a simple gray-body model of the flame, three different groups of analysts (Ref. 7-1, Sections $C, F$ and $G$ ) derived the three different curves for the flux vs pool diameter shown on the figure. For fires over $20 \mathrm{~m}$ in diameter, these curves differ by up to a factor of 1.8. However, as stated by the proponents of the highest of these three curves (Ref. 7-1, Sec. C), the lowest curve is based on the arbitrary assumption that large LNG fires should have the same surface flux as large fires of other hydrocarbons, while the middle curve is based on data that are not corrected for atmospheric absorption, so the upper curve appears preferable (though not unambiguously supported by the data).

Very recently, results from six fairly large test fires on a pond at China Lake have been published (Ref. 7-3). These data, also plotted on Figure 7-1, lie considerably above the three earlier curves. Moreover, from spectral measurements on one of the flames, the analysts deduced a 
flame temperature of $1500^{\circ} \mathrm{K}$ (Ref. 7-3), which implies a surface flux of $287 \mathrm{~kW} / \mathrm{m}^{2}$ for very large flames (having an emissivity of unity). This value is not inconsistent with an extrapolation of the China lake flux measurements, but it is about twice as high as the curves based on the older landfire data. Although the LNG boiloff rate during the fires on water was three to four times the average rate on the land fires, it has never been suggested that this difference, or other differences between land and water fires, would affect the surface flux. Until this difference is understood, it seems prudent to allow a margin of error of at least a factor of 2 in surface flux, which corresponds to a factor of about $2^{1 / 2}=1.4$ in the predicted safe distance from a large flame.

An additional uncertainty arises from the corrections for atmospheric absorption of the radiation. In all published ING flame analyses incorporating such corrections, they have been made as if the spectrum were a black or gray body. However, the spectral data show large deviations from the gray-body assumption, such that the absorption corrections used (typically 10 to 30 percent) should be significantly increased. On the other hand, very large. LNG flames probably become optically dense at most wavelengths and so approach a black-body spectrum (if their radiating region is isothermal); hence, the error in the conventional method of correction may not be as serious for them.

The total radiant flux from a pool fire also varies with the flame height. According to the conventional Thomas flameheight correlation, which fits the measurements on LNG pool fires up to $17 \mathrm{~m}$ in diameter fairly well (Refs. 7-1,7-3), the height-to-diameter ratio varies as the 0.61 power of the boiloff rate divided by the square root of the diameter. But the boiloff rate is determined in part by the radiative flux incident on the ING pool. In diked land fires, this mechanism 
causes a factor of 2 uncertainty in the flame surface flux to give an uncertainty factor of up to $2^{0.61 / 2}=1.2$ in the distance to a given flux level (in addition to the factor of 1.4 derived earlier). In unconfined pool fires on water the situation is more complex, because changes in the boiloff rate also change the pool diameter. Based on the Raj-Kalelkar theoretical result for the variation of the maximum pool diameter with boiloff rate, which appears adequate for rough estimates (see Section V), the change in flame height is nearly offset by a change in diameter in the opposite direction, so the total radiance of fires on water (at their maximum diameter) is relatively insensitive to uncertainties in the boiloff rate.

The determination of the radiant flux from large LNG flames is also complicated by time variations. One type of variation is a fairly rapid oscillation or "flicker," having a period on the order of a second for flames a few meters across. This flicker is apparently due to fluctuations in, both flame size and surface brightness. If these fluctuations are controlled by buoyant fluid motion, as seems probable, and Froude scaling holds (see sections $V$ and VI), the flicker period should be proportional to the square root of the flame diameter, and could exceed,10 $\mathrm{s}$ for a large accidental LNG spill on water. (A similar conclusion can be reached by. extrapolating to larger fires the flicker measurements of Portscht (Ref. 7-5) on alcohol pool fires of $0.001-$ to $0.7-\mathrm{m}^{2}$ base area.) Ten seconds is long enough that damage to some vulnerable materials (such as human skin) may depend partly on the peak radiance during the flicker, and not just on the mean flame radiance.

There are also slower changes in radiance. In a diked pool fire the flame height and emission probably peak as soon 
as the LNG has covered the dike floor, and then decrease as the ground cools and the boiloff rate decreases, approaching the steady-state condition where all of the boiloff is due to radiant heating of liquid. In a rapid spill on water the flame size probably increases as the LNG spreads, although the flame spreading may lag behind the liquid spreading. Unfortunately, it is not possible to check the above statements by using published data, since on the land fires only radiometer data during the later, steady-burning period were published (Ref. 7-1), and none of the water fires involved really rapid spills.

Toward the end of the LNG fires on both land and water the flames became redder and sootier, and often the emission rate increased (Ref. 7-1, Section H; Ref. 7-3), probably due to combustion of the heavier hydrocarbons in the LNG after the methane had been consumed.

The range of damaging thermal flux from an LNG pool fire is also affected by the wind speed, which determines the flame tilt. However, this is believed to be only a minor source of uncertainty, since the flame tilt decreases with increasing flame size; and a published correlation of tilt angle as a function of flame size, burning rate and wind speed fits data from fires involving both small wood cribs and LNG pools up to $15 \mathrm{~m}$ in diameter fairly well (Refs. 7-1 to $7-3)$.

The various problems discussed above imply that current estimates of the range to given flux levels from very large LNG fires have an uncertainty of at least a factor of 1.5 .

It has been argued (Ref. 7-2) that indirect information from the large accidental LNG fire in Cleveland in 1944 demonstrates the applicability of the conventional formulas to very large fires. However, there appear to be considerable 
uncertainties in the assumed diameter of this fire (about $200 \mathrm{~m}$ ), deduced from the area of spread of the mineral wool tank insulation, and on the distance to given radiation levels deduced from the positions where wood burned or paint blistered. Moreover, the claimed agreement of the observations is with the lowest curve on Figure 7-1, which seems clearly too low, as discussed earlier.

Another limitation of current knowledge is that no information is available on the effects of adjacent structures, such as tanks, high dikes or ship hulls, on LNG fires.

Mathematical models based on fundamental physical principles can sometimes substitute for missing experimental data. Fundamental models of LNG pool fires adequate for this purpose, however, are not yet available. Two specific models were developed in the past, but both make a number of simplifying approximations which make their accuracy questionable; in addition, the first model (Refs. 7-6,7-7) was mathematically complex and never carried through to the point of giving numerical results, while the second. (Refs. 7-6,7-7) included radiation only in the horizontal direction, omitted soot radiation, and had an ad hoc air entrainment term.

2. RESEARCH GOALS AND TECHNICAL APPROACH

The goals of the research recommended in this section are to obtain sufficient information to make confident predictions of the maximum distance to any specified radiation level between about 5 and $32 \mathrm{~kW} / \mathrm{m}^{2}$ (1600 to $10,000 \mathrm{Btu} / \mathrm{ft}^{2} / \mathrm{hr}$; see.p. 3-3), within an uncertainty range of a factor of 1.3 (or $\pm_{15}$ percent from the mean). for LNG fires in low dikes up to $200 \mathrm{~m}$ across, and a factor of 1.4 for fires on water from unconfined spills of up to $25,000 \mathrm{~m}^{3}$ next to a ship hull. The uncertainty in predictions for water fires is larger than that for land fires due to their 
greater size (requiring a longer extrapolation of test data) and the additional uncertainties of LNG spreading on water. Although smaller uncertainty factors would clearly be preferable, they are not believed to be attainable in the desired time period due to limitations in our theoretical understanding, and experimental inability to scale all the relevant parameters in a simulation test of reasonable size, as discussed below.

The quoted uncertainty factors are based on the belief that the actual test measurement errors will be small, their unaccounted-for variability (due to fluctuations and neglected variables such as detailed spilling parameters and atmospheric conditions) will be about a factor of.1.2, and the additional uncertainty introduced by the extrapolation to full scale will be roughly a factor of 1.1 (land) or 1.2 (water). (All of these values correspond to the uncertainty in the maximum distance to a given radiant flux; they should be roughly squared to get the uncertainty in flux at a given distance.)

With proper calibration, measurement errors can be held to a few percent in intensity, or about half that percentage in range. Past test data show that intensity variations from test to test, and with time for a given test, approach a factor of 2. However, this variability probably causes a smaller uncertainty in the deduced maximum intensity, due only to the failure of a limited number of tests to cover the full range of variability. This uncertainty is estimated to be a factor of 1.2 in range.

The estimates of 1.1 and 1.2 for the additional uncertainty factor due to extrapolation are rather arbitrary and may be overly optimistic. The uncertainty for the water fires is larger than that for land fires due to their greater size, which requires a longer extrapolation of the test data (assuming that data on the larger water test fires are also partially 
relevant to full-scale land fires), and to the additional uncertainties of LNG spreading and boiloff on water. At the end of the research program a better estimate of the uncertainty can be made by examining the consistency of the test data and its agreement with the best theoretical models. However, because of the considerable extrapolation required from even the largest of the proposed test fires, predictions for large LNG fires on water may not have high confidence until a complete and accurate turbulent pool-fire model is available, which may take five years. Fortunately, the most plausible deviations of large fires from simple models are a possible breakup into several smaller flame plumes and a shielding of the radiation by the thick, cooler flame edges, both of which would reduce the hazardous range.

The recommended research approach is primarily experimental, involving detailed measurements on several test fires on land and water (most of them larger than previous test fires but still considerably smaller than the fullscale accidental fires of concern), combined with semiempirical analyses and modeling of the results. A moderate-level effort on more detailed mathematical models is also recommended, partly to minimize the possibility of overlooking significant phenomena in the test measurements and analysis, and partly because it may eventually lead to models accurate enough to rely on for safety predictions. Details of the proposed research are discussed below.

\section{EXPERIMENTAL PROGRAM}

a. General considerations--The two most important parameters of an LNG fire pool that can be specified are the size of the pool and the surface on which it is poured, which determines the boiloff rate. Practically, the most important surfaces are water and packed soil (usually used in a dike impound area), with third importance assigned to materials 
having a low boiloff rate, such as insulating concrete or corrugated sheet metal (Ref. 7-9), which have been suggested for impound areas.

The size of the pool fire determines to a considerable extent the time and cost of a test. It.would be very convenient if a large fire could be closely simulated by a small test fire. However, there is no known way to reduce uniformly the radiative mean-free paths in the test fire at all important wavelengths, so the simulation cannot be complete. Moreover, for good simulation the Froude number should be held fixed (see Section V), so the specific boiloff rate should be varied like the square root of the fire diameter. In a test fire on land such a reduction might be effectively accomplished by employing a patchwork of barriers to confine the LNG to the desired fraction of the dike surface, or by úsing a dike floor material having a lower heat conductivity (although the reduction possible by the latter method is limited because it does not change that part of the boiloff due to radiant heating from the flame). For fires on water there is no known way of reducing the boiloff rate without changing the LNG spreading behavior (see section $\mathrm{v} \cdot 2 \mathrm{~b}$ ). If the boiloff rate is fixed instead of scaled, the empirical Thomas formula for flame height, which fits data from LNG pool fires up to $17 \mathrm{~m}$ in diameter reasonably well (Refs, 7-1 to 7-3), shows that as the fire size is increased its shape changes and it becomes broader and more squat. This behavior is illustrated in Figure 7-2 for fires of various sizes on water.

Fortunately, many pool fire parameters, such as the height-to-diameter ratio, the surface radiant flux and the spectrum, appear to change only slowly and systematically with fire size. Accordingly, it is believed that accurate measurements on large fires of two significantly different sizes will permit reasonably confident extrapolation to considerably 


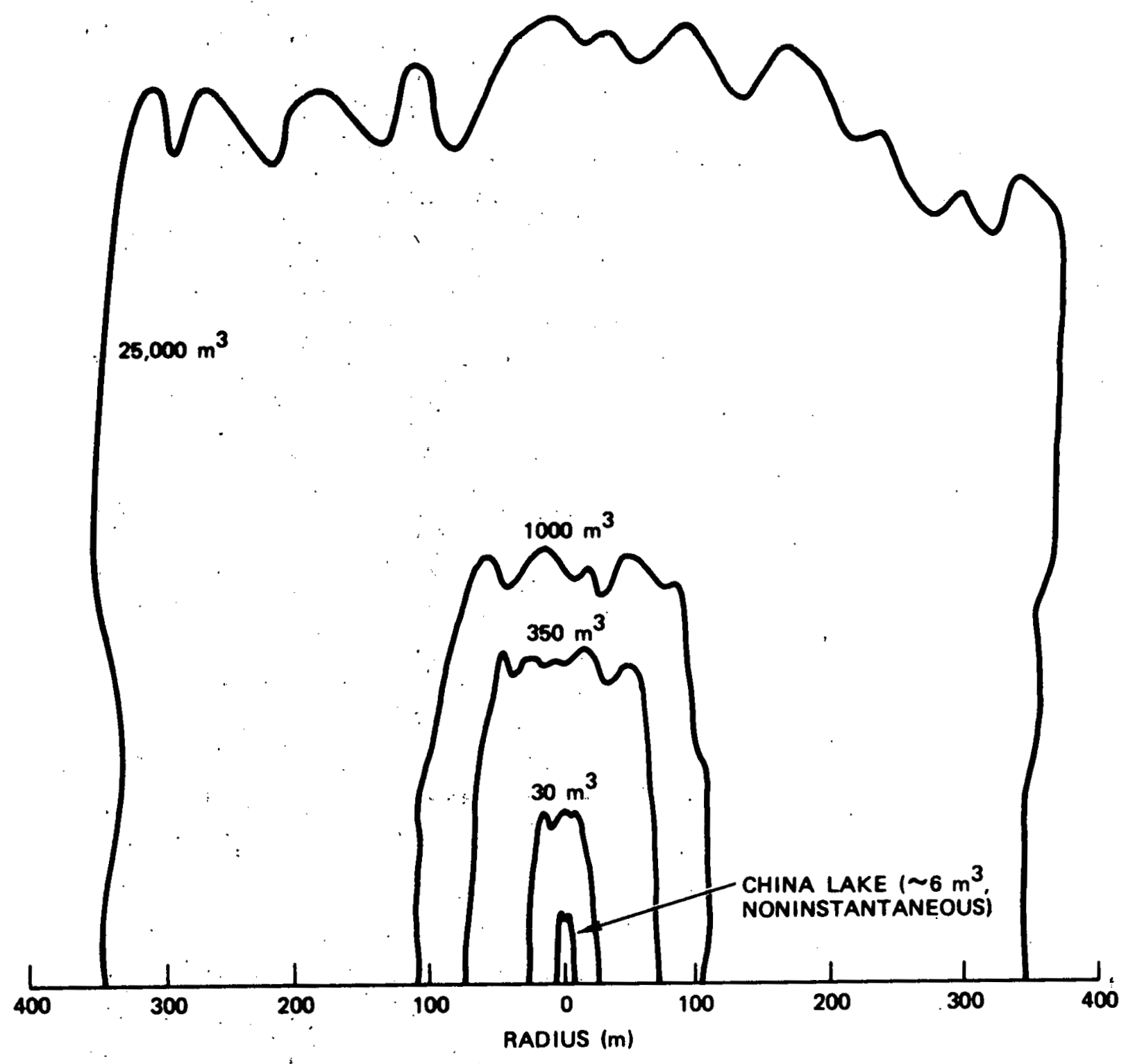

Figure 7-2. Sketch of the expected flame geometry for LNG pool fires on water, based on the Raj-Kalelkar pool spread model (with a boiloff rate of $0.065 \mathrm{~cm} / \mathrm{s}$ ) and the Thomas flame-height correlation. 
larger fires, provided that the important physical mechanisms do not change. The available experimental and theoretical information suggests that once a fire diameter of a few meters is reached, where soot becomes an important flame radiator, the basic flame mechanisms are unlikely to change. Accordingly, we believe that good data on a pool fire in the 25- $x$ 30-m dike described in section VI, together with parallel data on a fire of half that size, will allow a confident extrapolation to a fire in a full-size dike up to 100 or $200 \mathrm{~m}$ across. Similarly, data on rapid unconfined spills on water of $30-$ and $350-\mathrm{m}^{3}$ LNG, ignited to produce fires of about 55- and 140-m diameter, respectively, should provide adequate information for extrapolation to the 700-m-diameter fire that could be caused by a rapid $25,000-\mathrm{m}^{3}$ spill. Figure 7-2 illustrates the relative sizes and probable shapes of these fires on water and of the China Lake fires, which are the largest LNG fires for which extensive radiation data are available. This figure also demonstrates the relatively small advantage in simulation that would be obtained by going from a $350-\mathrm{m}^{3}$ test fire to a considerably more expensive $1000-\mathrm{m}^{3}$ test fire.

To obtain adequate accuracy and confidence in such extrapolations, it seems important to obtain complete infrared images of the test flames with reasonable spatial resolution, and some spectral resolution. Past observations and theoretical considerations suggest that different parts of the flame may emit different proportions of $\mathrm{H}_{2} \mathrm{O}$ and $\mathrm{CO}_{2}$ band radiation, soot radiation, and possibly hot hydrocarbon radiation (Ref. 7-3). These regions may scale differently with fire size, so they must be characterized individually to permit valid extrapolation. Conventional photography and measurements of the total radiation and total flame spectra alone are not adequate to permit such a characterization. 
In addition, spectra of the important radiating portions of the flame with fairly high resolution are needed to permit accurate corrections for atmospheric absorption between the flames and the instruments, and predictions of the absorption under various atmospheric conditions and ranges.

The range of damaging thermal flux from an LNG pool fire is also affected by the wind speed, which determines the flame tilt. However, as discussed earlier, the flame tilt decreases with increasing flame size, and the available correlation of tilt angle as a function of flame size, burning rate and wind speed (Ref. 7-2) is probably adequate. Accordingly, one large test each on land and water in a reasonably high wind should provide a sufficient check of wind tilt predictions for large fires, as well as verify the common assumption that the wind does not change the surface flux or spectrum.

b. Field tests--Based on the preceding considerations, a program of relatively large field tests of the LNG pool fires has been drawn up, as listed in Table 7-1. The purpose of tests 1 to 3 is to determine the effects of wind speed and dike size on land fires, while tests 6 to 8 serve the same purpose for fires on water. The low and high wind speeds indicated on the table were chosen to give a flame tilt of less than $5 \mathrm{deg}$ and more than 45 deg, respectively, based on the A. D. Little, Inc.; empirical correlation of previous poolfire data (Refs. 7-1 to 7-3).

Test 4 involves a dike with an insulated impound area, since insulation is a promising passive method of mitigating the potential hazards of accidental LNG spills. It is suggested that the LNG industry be invited to recommend the exact insulating material or materials to be used in this test. In addition, as a test of active mitigation measures, it is recommended that an appropriate organization be invited 
to install fire-fighting equipment and attempt to control one of the diked fires by spraying with water, foam or dry chemicals, after 1 or $2 \mathrm{~min}$ of undisturbed flame data have been taken.

TABLE 7-1. RECOMMENDED LNG POOL FIRE TESTS

\begin{tabular}{|c|c|c|c|c|}
\hline $\begin{array}{c}\text { Test } \\
\text { No. }\end{array}$ & $\begin{array}{c}\text { LNG }_{3} \text { V01. } \\
(\mathrm{m})\end{array}$ & $\begin{array}{c}\text { Spill } \\
\text { Surface }\end{array}$ & $\begin{array}{c}\text { Pool size } \\
(\mathrm{m})\end{array}$ & $\begin{array}{c}\text { Wind } \\
\text { speed } \\
(\mathrm{m} / \mathrm{s})\end{array}$ \\
\hline 1 & 100 & Soil floor & $25 \times 30$ & $<2$ \\
2 & 100 & Soil floor & $25 \times 30$ & $>4$ \\
3 & 25 & Soil floor & $12.5 \times 15$ & $<2$ \\
4 & 100 & Insulated & $25 \times 30$ & $<2$ \\
5 & 25 & Soil floor & $6.3 \times 30$ & $<2$ \\
6 & 350 & Water & $\sim 140$ diam. & $<6$ \\
7 & 350 & Water & $\sim 140$ diam. & $>12$ \\
8 & 30 & Water & $\sim 55$ diam. & $<5$ \\
$9-14$ & $\begin{array}{l}\text { Contingency tests (not larger than the above tests), } \\
\text { parameters to be determined during the test program. }\end{array}$ \\
\hline
\end{tabular}


All of the recommended test fires on land involve low dikes with level floors since a majority of existing dikes have such a design, and the potential fire hazard from dikes of this type is greater than that from other types. A high dike, with its reduced surface area, decreases the total boiloff rate so much that we do not give a high priority to tests of fires in a high dike. A sloping floor or sump in a low dike also reduces the potential hazard in the event of small spill; but if the spill is large enough to cover the entire dike floor, a slope or sump causes little change in the early period of maximum boiloff. Accordingly, for low dikes the condition of maximum free hazard can be investigated by using a test dike with a level floor, which minimizes the amount of LNG required. (The LNG volumes indicated on the table are sufficient to give about a 5-min burning time.) However, one fire test is included that is particularly pertinent to a smaller spill in a dike with a' sloping floor or sump. This is test 5, involving a pool fire of the same areas as that of test 3 but twice as long and half as wide. Such a geometry is similar to that of a sump or partially filled sloping-floor dike, and only limited data on fires of such geometry are currently available.

In all the tests the LNG would be spilled rapidly from a spill tank in the middle of a dike or body of water (except possibly for test 5, where the tank could be at the side of the narrow dike). Consequently, the tank must have sufficient external insulation to withstand a few minutes' exposure to fire, which does not appear to be a difficult requirement. For aerodynamic reasons during vapor dispersion tests (see Section VI), an outer false tank will surround the land tank to give it a shape similar to a full-scale storage tank. It is desirable to use this same structure during the fire tests. In the large fires on water the spill tank covers 
less than 1 percent of the pool-fire area, so its effects should be negligible. Of course, in a potential full-scale accident the spill would occur from a relatively larger LNG tanker, but the area of the tanker is still less than 2 percent of the predicted maximum pool-fire area. The ship's hull also would restrict the early spreading of the LNG and yield a slightly noncircular pool fire, but the effect on the radiation field should be small and probably can be estimated from the slightly nonsymmetric diked fires. Accordingly, the expense of constructing a fire-resistant ship model for the water tests does not seem justified. However, if the wind tunnel tests show that a ship model is needed for the vapor dispersion tests (see Section VI), and if it is cheaper to construct it of fire-resistant material than to move it away for the fire tests, then of course it may be used.

Because the ethane and propane content of the LING affects the amount of soot in the flame and possibly the boiloff rate of the LNG on water, all the field tests should be carried out using a standardized LNG compositioñ, as discussed in Section V.2c.

The required instrumentation for the pool fire tests is summarized in Table 7-2. For the basic radiation measurements with spatial and spectral resolution, we recommend two types of instruments. One is a scanning infrared imaging device, such as the AGA Thermovision Camera, which provides a continuous picture (24 frames/second) of the infrared emitting areas over approximately the 1.5 - to $5.5-\mu \mathrm{m}$ spectral region, using an indium antimonide detector. Either the Dual Model 780 instrument, which has two parallel optical systems and detectors, or two separate instruments should be used to view the entire flame (including a possible infrared-emitting region above the visible flame), with one channel filtered so as to observe only the soot-emitting portions, utilizing a limited spectral region between the molecular bands. 
TABLE 7-2. INSTRUMENTATION FOR THE LNG POOL-FIRE TESTS

1 - AGA Thermovision camera, Mode 1 780 Dual, or equivalent (two channels, each covering $1.5-5.5 \mu \mathrm{m}$ infrared region or a portion thereof if filtered)

1. Michelson interferometer spectrometer (approximately $1.5-5.5 \mu \mathrm{m}$ ), steerable with aligned movie camera and radiometer

9 - Narrow-angle radiometers

5 - Wide-angle radiometers.

5 - Pool radiometers

3 - Movie cameras

2 - Spil1-rate instruments

2 - Wind velocity and direction instruments

2 - LNG samples for quantitative analysis

2 - Humidity measurements

6 -' Thermocouples for monitoring tank temperature

10 - Skin simulants, $100 \mathrm{~Hz}$; numerous wood targets

$\$ 00$ - Thermocouples for LNG spread on water

3 - Liquid-level gage for dike spills

$7-17$ 
The second type of instrument is a Michelson interferometer spectrometer, which takes several spectra per second over approximately the 1.5- to: 5.5-um region. This spectrometer should have provision either for manual or for automatic switching between a wide field of view, covering the entire flame, and a narrow field of view that can be steered to different portions of the flame. A radiometer with the same narrow field of view and a wide-angle movie. camera with cross hairs and a timing marker should be attached to the same steerable mounting, in alignment with the spectrometer, to record the total (spectrally integrated) radiation and the direction of observation, respectively.

In addition, the radiation instrumentation should include several fixed, narrow-angle radiometers viewing different parts of the flame from different directions, a few wide-angle radiometers viewing the entire flame, and a few pool radiometers looking upward from just above the LNG surface to measure the flux contributing to boiloff, such as were used in the AGA Phase II tests (Ref. 7-1). About 10 skin simulant devices, which employ a thermocouple to measure the rise in surface temperature (Ref. 7-1), and numerous wood block targets should also be deployed.

The scanning infrared images, the spectrometer and the radiometers should all be located as close to the fire as allowed by field-of-view and safety considerations, to minimize atmospheric attenuation of the radiation. Before and after each test the atmospheric attenuation should be measured as a function of wavelength over essentially the same optical path, using, the Michelson spectrometer and a standard blackbody radiation source. All data from these and the other instruments should be recorded on magnetic tape for later reduction and analysis, together with accurate timing markers to permit cross correlation of the data. Generally, a time resolution of $0.1 \mathrm{~s}$.should be adequate. 
In addition to the radiation instruments, these tests. should be covered by the usual movie cameras, wind and humidity instrument's, and devices for measuring LNG spill rate and spread (on water) or depth (on land), and ice formation.

c. Extended effort--If it is desired to support a longer range research program to give a more complete understanding of LNG pool fires and permit better predictions for a greater variety of practical cases, several additional field tests should be added. These would include fires in a simulated high dike and in a low dike with a sloping floor, and a small fire on water next to a large wall, simulating the line-break spill described in section V. All of these tests should be conducted both in a low (or zero) wind and in a fairly high wind.

In addition, some measurements of temperatures and perhaps other parameters inside the flames should be performed on many of the fire tests. Such measurements were not recommended for the basic effort because coverage of the interesting regions of these large fires (especially the fires on water) would be quite expensive, requiring tall towers and long. flame-resistant leads, and because their results appear unlikely to have much affect on the simple flame models derived from radiation data. However, such detailed measurements could be very useful for developing and checking the more complete flame models proposed for the extended theoretical effort. The measurements could include thermocouples to measure temperature, gas samplers to measure composition, and laser beams to measure the total soot opacity along a few paths through the flame. The possibility of using some of the laser scattering methods recently developed (Ref. 7-10) for determining flame temperature profiles, species concentrations and velocities should also be considered. However, there are considerable 
difficulties in applying these methods to large flames; in fact, some investigators have recently stated that because of turbulence problems their method probably will have to be confined to combustors $10 \mathrm{~cm}$ or less in size (Ref. 7-11).

Finally, some measurements of the fire-induced air motions at varying distances outside the flames would be useful. These could be carried out by releasing smoke puffs at various points and determining their motion from photographs.

\section{MATHEMATICAL MODELING}

a. Basic effort--A certain amount of semiempirical modeling of LNG pool fires is required to provide some understanding of the results obtained in the field tests and to fit these results with expressions that can be applied to larger fires. This modeling would be in the spirit of the past simple radiating-cylinder models, but more detailed. It would begin with a careful examination of the spectrographic, photographic and radiometric data from the AGA Phase II tests (Ref. 7-I) and the recent China Lake tests (Ref. 7-3), to determine if they could be better explained by the presence of two or more radiating regions having different compositions and/or temperatures. Both the data and physical principles would be used to estimate the parameters of each region and how they would vary with fire size. When more detailed data became available from the larger tests recommended herein, these estimates would be improved.

It is also recommended that a moderate effort be devoted to a more basic model of pool fires. This model would be similar but more complete than that developed by Wilcox (Ref. 7-8), and closer to that started by TRW researchers (Refs. $7-6,7-7)$, but without attempting to include wind effects. As in those models, the two-dimensional equations would be reduced to equations in a single (vertical) direction by 
assuming a fixed shape for the radial variations of velocity, temperature and composition, but instead of arbitrarily using a Gaussian (TRW) or trapezoidal (Wilcox) profile, profiles based on measurements on smaller hydrocarbon flames (Ref. 7-12) should be used. The recent simplified expressions of Yuen and Tien (Ref. 7-13) for radiation from $\mathrm{H}_{2} \mathrm{O}, \mathrm{CO}_{2}$ and soot, and the four-flux model of radiative heat transfer proposed by Gasman and Lockwood (Ref. 7-14) will probably shorten the computations considerably. A small preliminary analysis should be carried out to determine whether the concentrations of the radiating specie's can be determined with adequate accuracy by local equilibrium relations, as suggested by TRW, : or by a more detailed kinetic calculation, such as that presented by Jensen (Ref. 7-15) and Roper and Smith (Ref. 7-16) for soot. The relation assumed for entrainment of air by the flame plume should be consistent with the available measurements (Refs. 7-12,7-17) on smaller flames, and should include the effects of the "fire wind" (Ref. 7-18).

b. Extended effort-After completion of the basic research effort on pool fires recommended above, an extrapolation of the results to fires about five times larger in diameter is required. Since, as explained earlier, accurate scaling laws do not hold, our confidence in the extrapolation may be questioned. A detailed flame model based on fairly fundamental physical principles, with a minimum of empiricism, would provide (after checking with test data) an extrapolation method of considerably greater confidence. Such a model would incorporate not only a good turbulent mixing model, but also models for the chemical kinetics and the radiation. Models for all three of these processes are currently available, and incorporating them in a computer code might seem straightforward though time-consuming. 
Unfortunately, as the more sophisticated turbulence models have been applied to combustion problems in the last three or four years, it has become clear that models that are quite accurate in ordinary mixing situations are much less so in situations involving chemical reactions (Refs. 7-19,7-20). This problem is currently under extensive study by several groups of basic investigators, and steady progress is being made. However, we estimate that four to five years will be required to settle on an adequate turbulence model, develop a two-dimensional computer code for axially symmetric flames that also include combustion and radiation, and check it against results from at least some of the large pool-flame tests. Accordingly, this task is not included in our basic two- to three-year effort. However, it should have high priority in any extended or follow-on effort. 
7-1. LNG Safety Program, Interim Report on Phase II Work, AGA Project IS-3-1, Battelle Columbus Laboratories, July 1 , 1974 .

7-2. Raj, P.P.K., "Calculations of Thermal Radiation Hazards from LNG Fires. - A Review of the State-of-the-Art," presented at the AGA Transmission Conference, St. Louis, Missouri, May 18, 1977.

7-3. Raj, P.P.K. et al., Experiments Involving Pool and Vapor Fires from spills of Liquefied Natural Gas on Water, A. D. Little, Inc., Report \#82404, March 1979.

7-4. May, W. G., and McQueen, W., "Radiation from Large Liquefied Natural Gas Fires," Combust. Sci. Tech.' Vol. 7, 1973, pp. 51-56.

7-5. Portscht, R., "Studies on Characteristic Fluctuations of the Flame Radiation Emitted by Fires," Combust. Sci. Tech., Vol. 10, 1975, pp. 73-84.

7-6. Thermal Radiation and Overpressures from Instantaneous ING Release into the Atmosphere, TRW Systems Group, Report No. 08072-4, April 26, 1968.

7-7. Thermal Radiation and Overpressures from Instantaneous LNG Release into the Atmosphere - Phase II, TRW Systems Group, Report No. 08072-9, May 1969 .

7-8. Wilcox, D. C., "Model for Fires with Low Initial Momentum and Nongray.Thermal Radiation," AIAA J., Vol. 13, March 1975, pp., 381-386.

7-9. Reid, R. C., and Wang, R., "The Boiling Rates of ING on Typical Dike Floor Materials," Cryogenics, July 1978, pp. 401-404.

7-10. Sochet, L. R., Lucquin, M., Bridoux, M., Crunelle-Cras, M., Grase, F., and Delhaye, M., "Use of Multichannel Pulsed Raman Spectroscopy as a Diagnostic Technique in Flames," Combust. Flame, Vol. 36, 1979, pp. 109-116.

7-11. Pealat, M., Druet, S., Attal, B., and Taran, J., "Temperature and Concentration Measurements in Reactive Media by Coherent Anti-Stokes Raman Scattering," Sixteenth Symp. (Internat.) on Combustion, Combustion Institute, Pittsburgh, 1977, pp. 789-798. 
7-12. Becker, H. A., and Yanazaki, S., "Entrainment, Momentum Flux and Temperature in Vertical Free Turbulent Diffusion Flames," Combust. Flame, Vol. 33, 1978, pp. 123-149.

7-13. Yuen, W. W., and Tien, C. L., "A Simple Calculation Scheme for the Luminous-Flame Emissivity;" Sixteenth Symp. (Internat.) on Combustion, Combustion Institute, Pittsburgh, 1977, pp. 1481-1487.

7-14. Gasman, A. D., and Lockwood, F. C., "Incorporation of a Flux Model for Radiation into a Finite-Difference Procedure for Furnace Calculations," Fourteenth Symp. (Internat.) on Combustion, Combustion Institute, Pittsburgh, 1973, pp. 661-671.

7-15. Jensen, D. E., "Prediction of Soot Formation: A New Approach," Proc. Roy. Soc. Lond., Vol. A338, 1974, pp. 375-396:

7-16. Roper, F. G., and Smith, C., "Soot Escape from Laminar Air-Starved Hydrocarbon Flames," Combust. Flame,

Vol. 36, 1979, pp. 125-138.

7-17. Thomas, P. H., Baldwin, R., and Heselden, A.J.M., "Buoyant Diffusion Flames: Some Measurements of Air Entrainment, Heat Transfer, and Flame Merging," Tenth Symp. (Internat.) on Combustion, Combustion Institute, Pittsburgh, 1965, pp. 983-996.

7-18. Smith, R. K., Morton, B. R., and Leslie, L. M., "The Role of Dynamic Pressure in Generating Fire Wind," J. Fluid Mech., Vol. 68, 1975, pp. 1-19.

7-19. Donaldson, C. duP., "Some Observations on the Calculation of Turbulent Diffusion Flames Using Full SecondOrder Closure Techniques," Bull. Amer. Phys, Soc., Vol. 24, 1979, p. 60 .

7-20. Spalding, D. B., "How Turbulence Influences the Rate . of Chemical Reaction," Bull. Amer. Phys. Soc., Vol. 24, 1979 , p. 60 . 
VIII. RECOMMENDED RESEARCH ON VAPOR-CLOUD FIRES

\section{INTRODUCTION}

For LNG safety evaluations, one needs reliable methods for predicting the thermal radiation hazards associated with the burning of large clouds of LNG vapor that are partly or wholly premixed with air. Such fires may result from accidental spills of LNG on land or water if the resulting vapor drifts away from the liquid and mixes with air before it pecomes ignited.

Past experimental studies of vapor-cloud. fires have been limited to spills of only a few cubic meters of LNG on land and water (Refs. 8-1,8-2). These studies have yielded useful data on the vapor-cloud burning mode, flame size and shape, and flame propagation velocity. However, no spectral data were taken on any of the tests, and radiometer measurements were made only on five water-spill tests (Ref. 8-2), which had several limitations. All were roughly the same size, and all were ignited at about the same distance from the spill point, at a position significantly closer than the maximum extent of the flammable cloud. Moreover, narrow-angle radiometer measurements were made only near the base of the flame while it temporarily remained stationary at the elevated edge of the spill pond. Such stationary behavior was not generally observed while these and earlier test fires were burning over flat land. In the stationary flames the ratio of length (slant height) to thickness (in the wind direction) was only around 0.3 to 0.8 (Ref, $8-2$ ), while in moving flames this ratio was 1.5 to 2.8 (Ref. $8-3$ ).

Perhaps the greatest limitation of existing data on LNG vapor-cloud fires is their restriction to spills of $5.5 \mathrm{~m}^{3}$ or less. (except for one large A.G.A. test (Ref. 8-4), where ignition 
occurred early and few data were taken before the flame burned back to the LNG pool). Since the roles of buoyancy, soot emission, and possibly other processes are believed to increase with increasing flame size, without data from larger tests or a well-grounded theory, one cannot predict with confidence the

- behavior of the much larger vapor-cloud fires that could result from large accidental ING spills:

Existing theoretical models of vapor-cloud fires also have serious limitations. The "wall-of-fire" model of Raj and Emmons (Ref. 8-3) makes six simplifying assumptions, relies on empirical data for some parameters, and does not include a flameradiation model. (Use of one of the pool-fire radiation models discussed in Section VII may not be justified here because the vapor cloud is usually premixed with air.) The "fireball" model of Fay and Lewis (Refs. 8-5,8-6) assumes a flame geometry different from that observed in all past LNG tests. The numerical hydrodynamic model developed at Lawrence Livermore Laboratory (Ref. 8-7) makes fewer assumptions, but is currently restricted to two-dimensional geometries and requires prior knowledge of the appropriate burning velocity. None of these models have been applied to any of the fire tests where radiation measurements were made and, in fact, the wide-angle radiometer data most relevant for checking safety predictions, though recorded (Ref. 8-2), have not been published. In the absence of such comparisons, it is difficult to estimate the accuracy of the radiant intensity predictions they would give. Indirect evidence suggests that the errors probably would be greater than a factor of 2, except perhaps for the two-dimensional hydrodynamic code, which is restricted to central ignition of symmetric vapor clouds.

Outlined below is a research program that has the goal of obtaining sufficient information to make confident predictions, within an uncertainty range of a factor of 1.4, of the position 
and dimensions of the region that receives a given level of thermal radiation from the fire produced by ignition of the vapor cloud from a spill of up to $25,000 \mathrm{~m}^{3}$ of $\mathrm{LNG}^{\circ}$ on water, or into a low dike up to $200 \mathrm{~m}$ across, with ignition at times and positions likely to maximize the extent of the potential hazard region. The recommended approach to this goal relies principally on detailed measurements of the dynamics and radiation of several vapor-cloud fires from spills of hundreds of cubic meters of LNG under selected conditions, combined with sufficient theoretical and modeling studies to permit extrapolation to larger spills and to spills under different conditions than those tested. Use is also made of information on vapor dispersion and flame propagation obtained in the studies described in section VI and IX. The proposed research program is discussed in more detail below. If similar information on LPG vapor-cloud fires should be desired, essentially the same type of field tests and mathematical models should be applied to that fuel.

\section{EXPERIMENTAL PROGRAM}

a. General considerations--The behavior of an LNG vaporcloud fire is determined by the size, shape and concentration distribution of the cloud, the position of the ignition point, the wind speed and possibly other meteorological parameters such as the atmospheric stability and temperature, and the terrain geometry and roughness. The cloud parameters before ignition are controlled in turn by the parameters of the LNG spill that produced it, and by the same meteorological and terrain parameters that may influence the flame propagation. A field test program that studied the effects of varying all of these parameters would be very lengthy and expensive. Fortunately, the effects of these parameters on the cloud before ignition can be more conveniently studied in the wind tunnel and 
on the computer, with selected verification by a few field tests, as discussed in section VI. If extensive use of these vapor dispersion results is made and emphasis is placed on conditions likely to maximize the area or the downwind distance of the region of significant radiation from a potential vaporcloud fire, the required field tests can be reduced to a reasonable number.

As discussed in section VII for pool fires, it is not possible to perform Froude-scaled vapor-cloud fire tests which accurately simulate much larger fires, because there is no known way to reduce the radiative mean-free paths by the proper ratio or, for the vapor-cloud fires, to reduce the burning velocity simi-a larly. Accordingly, the best way to attain a capability for making good predictions of the danger region around a large vapor-cloud fire appears to be to make measurements on several test fires that are as lärge as readily feasible, and combine this information with results from theoretical and semiempirical studies. Since the flame parameters are expected to change only slowly with flame size, there is no convincing reason to go to test spills larger than those already recommended for vapor dispersion and pool flames. Hence, the same spill facilities can be used. Since radiation measurements with spatial and temporal resolution are needed to determine the radiant flux at different places and times, the data will cover early times when the fires are relatively small, and it is believed that these data will indicate sufficiently well how the flame parameters vary with size without the need for smaller tests.

b. Recommended field tests--Table 8-1 lists the seven tests recommended for the vapor-cloud fire studies, plus eight contingency tests, to be performed if any of the first seven experience serious instrument failures or give results suggesting that additional tests are needed to cover the parameter range of 
TABLE 8-1. RECOMMENDED LNG VAPOR CLOUD FIRE TESTS

\begin{tabular}{|c|c|c|c|c|c|}
\hline $\begin{array}{l}\text { Test } \\
\text { No. }\end{array}$ & $\begin{array}{l}\text { LNG vol. } \\
\left(\mathrm{m}^{3}\right)\end{array}$ & Spill surface & $\frac{\text { Ignition cond }}{\text { Time }}$ & $\frac{\text { itions }}{\text { Postion }}$ & Wind speed \\
\hline 1 & 350 & Water & $\begin{array}{l}\text { Max. down- } \\
\text { wind flamm. } \\
\text { extent }\end{array}$ & $\begin{array}{l}\text { Downwind } \\
\text { edge }\end{array}$ & a \\
\hline 2 & 350 & Water & $\begin{array}{l}\text { Max. extent } \\
\text { of contin- } \\
\text { uous flamm. } \\
\text { path from } \\
\text { pooi }\end{array}$ & $\begin{array}{l}\text { Downwind } \\
\text { edge }\end{array}$ & a. \\
\hline 3 & 350 & Water & $\begin{array}{l}\text { Max. extent } \\
\text { of contin- } \\
\text { uous flamm. } \\
\text { path from } \\
\text { pool }\end{array}$ & $\begin{array}{l}\text { Downwind } \\
\text { edge }\end{array}$ & Low \\
\hline 4 & 350 & Water & $\begin{array}{l}\text { Max. size } \\
\text { flamm. } \\
\text { region }\end{array}$ & Centroid & High \\
\hline$\cdot 5$ & 350 & Water & $\begin{array}{l}\text { Max. size } \\
\text { flamm. } \\
\text { region }\end{array}$ & Centroid & Low \\
\hline 6 & 100 & $\begin{array}{c}\text { Soil } \\
\text { Impound } \\
25 \times 30 \mathrm{~m}\end{array}$ & $\begin{array}{l}\text { Max. down } \\
\text { wind flamm. } \\
\text { extent }\end{array}$ & $\begin{array}{l}\text { Downwind } \\
\text { edge }\end{array}$ & a \\
\hline 7 & 100 & $\begin{array}{c}\text { Soil } \\
\text { Impound } \\
25 \times 30 \mathrm{~m}\end{array}$ & $\begin{array}{l}\text { Max. size } \\
\text { flamm. } \\
\text { region }\end{array}$ & Centroid & Moderate \\
\hline $8-$ & \multicolumn{3}{|c|}{$\begin{array}{l}\text { Contingency tests (not larger than the above } \\
\text { be determined during the test program. }\end{array}$} & tests), par & ameters to \\
\hline
\end{tabular}

a Wind speed chosen to maximize the downwind flammable extent, based on windtunnel and field measurements of vapor dispersion (see Setion VI). 
greatest safety concern. The first five tests are of spills on water, with ignition conditions corresponding to three situations: the maximum downwind distance one can get a fire, the maximum distance one can get a fire that propagates all the way back to the spill point (which distance is probably considerably shorter than the first distance), and the maximum size premixed vaporcloud fire one can get. In the latter two cases, two different wind speeds are to be employed. All of these tests would be under conditions where the vapor cloud was blown over land, since such situations are of the greatest public safety concern and also it is easier to deploy instrumentation on land.

Only two tests of vapor-cloud fires from spills in dikes are listed, partly because such spills release vapor at a more steady rate than water spills, so that there is probably less difference between the maximum downwind ignition distance and the maximum distance from which a flame will burn back to the spill-point pool. A second reason is that smaller vapor clouds are formed by the land-test spills than by the larger water-test spills, so they less closely simulate the large accidental clouds of interest.

The exact ignition times and positions, and the meteorological and topographic conditions for these tests should be chosen later, on the basis of the vapor dispersion results from the wind tunnel and field experiments and the mathematical modeling described in section VI. Probably a flat, relatively smooth topography is of greatest practical interest, although in some coastal situations a significant rise of the land near the edge of the water may occur. (In the china Lake test [Ref. 8-2] such a rise may have been responsible for stopping temporarily the motion of the flame front.) Some of the contingency tests listed in Table 8-1 may be used to explore the effects of varying such parameters. 
Essentially the same measurements with the same instrumentation should be made on the vapor-cloud fire tests as on the pool-fire tests (see Table 7-2), for the same reasons (see Section VII). The principal difference is that the vapor-cloud flames will tend to move and predictions of this motion have large uncertainties. This makes coverage by the infrared imaging camera, which has both spatial and temporal resolution, especially important. It also implies that many of the radiation instruments and cameras will have to be stationed farther away to cover a larger area (which increases the effects of atmospheric absorption*) unless they have very large fields of view. Alternatives of employing duplicate instruments covering different portions of the region, or instruments that can be remotely steered during the test, should be analyzed for their cost effectiveness.

In order to follow the motions of the vapor cloud and the flame front, it is important to place movie cameras upwind or downwind, to the side, and high above the cloud region. However, parts of the flame may be nearly invisible (when the cloud is well mixed with air), or hidden behind fog or other flames. Accordingly, about 50 thermocouples or ionization probes should be stationed at various heights in the predicted combustion region to record passage of the flame front. In addition, measurements of the LNG vapor concentration at points inside and just outside the flammable cloud before flame arrival would be very useful. The instruments described in section VI could be used for this purpose, but their use would be constrained by the possibility of fire damage and the cost of repair or replacement. The prospects for developing a vapor concentration sensor

\footnotetext{
‡Measurements of atmospheric absorption versus wavelength should
} be made before and after each test, along the same optical path. 
that would not be seriously damaged by fire should be investigated early in the program.

c. Extended effort--If a more complete and longer research program to cover a wider variety of vapor-cloud fires is

desired, additional field tests should be added to cover ignition at different times and positions (such as ignition at the side of a cloud, or ignition at the downwind edge near the time of maximum flammable volume), different wind speeds, and different topography (such as vapor flow up a sloping beach versus up a palisade).

\section{MATHEMATICAL MODELING}

a. Basic effort--A certain amount of simple semiempirical modeling is desirable to provide rough predictions for field tests and accidental spills until better information becomes available. This should start with the model recommended in the recent report on the China Lake tests (Ref. 8-2), which assumes a radiating volume of hot water vapor, carbon dioxide and soot at a fixed temperature. Refinements, such as multiple radiating regions and variable temperatures, should be added as additional data and theoretical analyses suggest their desirability.

In addition, a more fundamental modeling effort is recommended utilizing numerical models of turbulent combustion, such as have been developed at the Lawrence Livermore Laboratory (Ref. 8-7). The principal limitation of such models is that they contain an arbitrary turbulence parameter which, at present, can only be evaluated by use of experimental turbulent flame velocities. These velocities differ for different scales and intensities of turbulence in a manner that is not completely understood. However, laboratory experiments on turbulent flame velocities (as recommended in section IX), and later the field tests discussed in this section, should give more realistic input data for such numerical calculations. 
The initial calculations should utilize a two-dimensional code to calculate the combustion of cylindrical ING vapor-air clouds ignited at the center. The cloud dimensions should correspond to those expected for the field tests and for fullscale accidental spills, and calculations should be made for three or four different values of the burning velocity. These calculations should be revised when laboratory experiments and field tests give better values for the cloud dimensions and burning velocities.

In addition, the cost effectiveness of developing and using a three-dimensional combustion code for nonsymmetric clouds or noncentral ignition should be evaluated. The cost will depend upon whether a combustion subroutine can be readily added to an existing three-dimensional hydrocode, such as those discussed in section VI. The effectiveness will depend upon whether a general relation between the burning velocity and the local hydrodynamic and thermal properties can be derived experimentally or theoretically. If the evaluation is favorable, such a three-dimensional code should be developed and applied to all of the field test situations, (Table 8-1), and to the full-scale situations of greatest practical importance. If necessary, appropriate revisions in the code should be made in the light of the field test results.

b. Extended effort--If a more complete research program is chosen, the semiempirical modeling and the three-dimensional code calculations should be extended to cover the additional situations included in the extended experimental effort. Moreover, one or more three-dimensional combustion codes should be developed and employed, even if rather expensive. Finally, a theoretical study of the relation between the burning velocity and the intensity and scale of turbulence should be initiated. 
8-1. Raj, P.P.K., "Calculations of Thermal Radiation Hazards from LNG Fires - A Review of the State-of-the-Art," presented at the AGA Transmission Conference, St. Louis, Missouri, May 18, 1977.

8-2. Raj, P.P.K., et al., Experiments Involving Pool and Vapor Fires from Spilis of Liquefied Natural Gas on Water, A. D. Little Report No. 82404, March 1979.

8-3. Raj, P.P.K., and Emmons, H. W., "On the Burning of a Large Flammable Vapor Cloud," Western and Central States Section of the Combustion Institute, San Antonio, Texas, April 21-22, 1975.

8-4. LNG Safety Program, Interim Report on Phase II Work, AGA Project IS-3-1, Battelle Columbus Laboratories, July 1,1974 .

8-5. Fay, J. A., and Lewis, D. H., "Unsteady Burning of Unconfined Fuel Vapor Clouds," Sixteenth Symp. (Internat.) on Combustion, Combustion Institute, Pittsburgh, PA, 1976, pp. 1397-1405.

8-6. Fay, J. A., Desgroseilliers, G. J., and Lewis, D. H., "Radiation from Burning Hydrocarbon Clouds," Combust. Sci. Tech., Vol. 20, 1979, pp. 141-151.

8-7. Hogan, W. J., Bowman, B. R., and Haselman, L. C., "Numerical Modeling of LNG Spill Phenomena," Lawrence Livermore Laboratory, Preprint UCRL-82031, December 13, 1978 . 
IX. RECOMMENDED RESEARCH ON THE

POTENTIAL OF LNG VAPOR EXPLOSIONS

\section{INTRODUCTION}

If a large accidental LNG spill should occur, there is concern that the resulting vapor-air cloud might detonate or explode, causing damaging overpressures at significant distances outside of the cloud. A detonation might be initiated by a lightning stroke, a strong spark, a bursting compressedgas bottle, or conceivably an ordinary flame, if a subsequent transition from deflagration (slow burning) to detonation should occur. The energy that would be released in the detonation of $25,000 \mathrm{~m}^{3}$ of LNG is equivalent to the energy contained in 140 kilotons of TNT, which is enough to cause blast damage out to several kilometers. However, tests have shown that unconfined clouds of LNG vapor (or natural gas) are extremely difficult to detonate (see below), and no such clouds are known to have accidentally detonated.

The initiation of detonation in LNG vapor-air mixtures by compact (near-spherical) charges of high explosive has recently been studied experimentally by Bull et al. (Refs. 9-1 to 9-3) and by Lind*. For experimental convenience they placed their combustible mixtures in thin plastic bags or balloons rather than having them completely unconfined, but this did not affect the detonation initiation, since that occurred before any disturbance reached the bag walls. Their results for stoichiometric hydrocarbon-air mixtures are summarized in Figure 9-1, where broken curves indicate interpolated or extrapolated values. This figure shows that a mixture of pure methane with air is especially difficult to detonate. To our, knowledge it

*Discussions with C.D. Lind, Naval Weapons Center, August 8 , 1978, and April 27, 1979. 


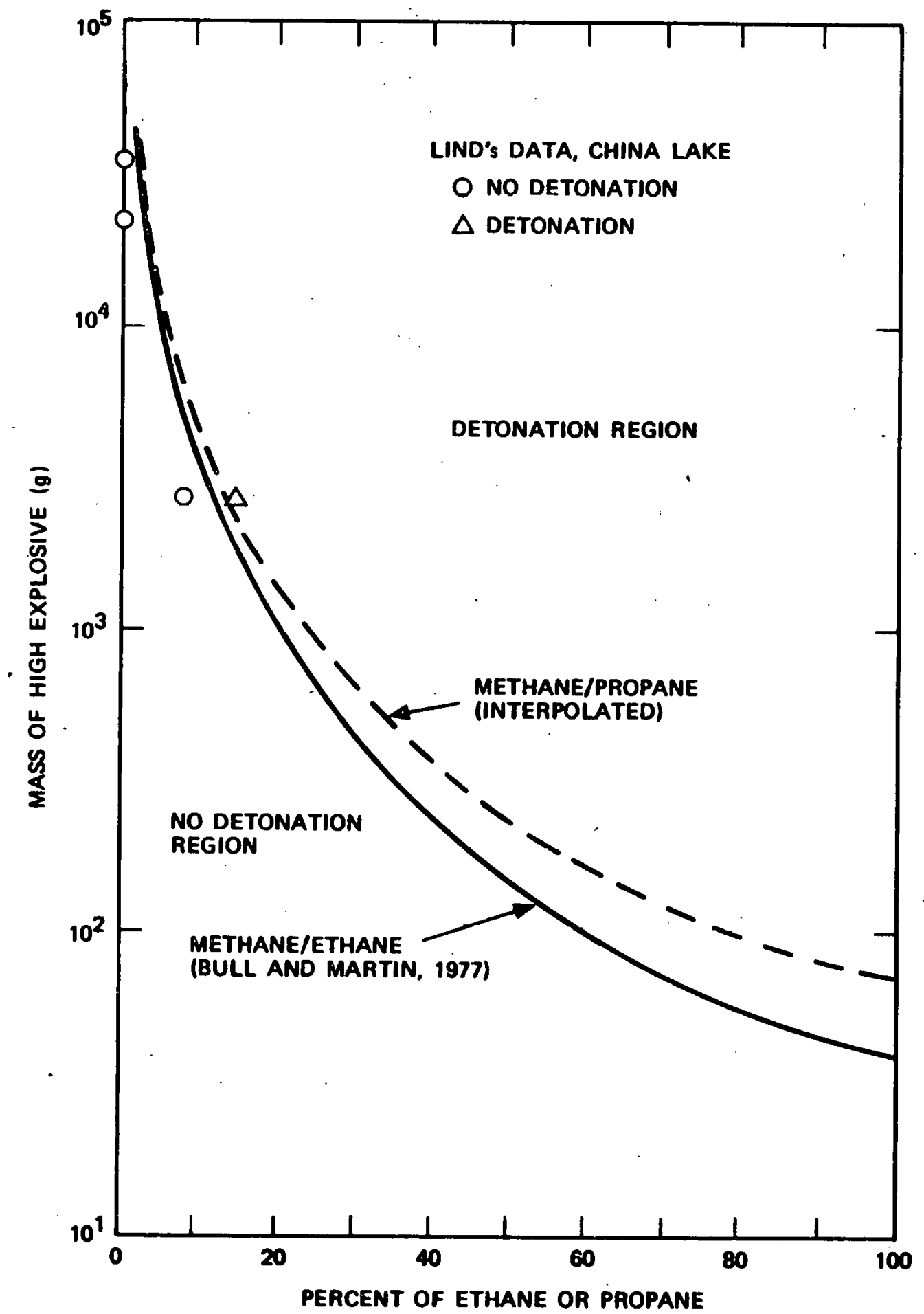

Figure 9-1. Compact mass of high explosive required to initiate detonation in a stoichiometric mixture of air and methane with a varying fraction of ethane or propane. 
has never been accomplished with a compact charge as an initiator. However, Benedick (Ref. 9-4) appears to have produced detonation in such a mixture with $4.1 \mathrm{~kg}$ of a thin, planar sheet of explosive. It is also clear from the figure that admixtures of small quantities of ethane or propane to the methane can strongly increase the detonability. This is due to the reduced induction time resulting from addition of the heavier hydrocarbons, as shown by Westbrook's detailed chemical kinetics calculations (Ref. 9-5). Much LNG contains 10 percent or more ethane or propane, which can make it considerably easier to detonate. However, in an LNG spill confined in a dike, and possibly in an unconfined one (as on open water), the methane boils off first, then the ethane and propane (see section V). If subsequent atmospheric dispersion processes do not remix these components, an LNG spill can produce two or three vapor clouds with rather different detonation properties. It is for this reason that field measurements of differential boiloff and differential dispersion were recommended in sections V and VI of this report.

The fact that detonations have been achieved in homogeneous stoichiometric mixtures with explosive initiators does not imply that unconfined LNG vapor clouds are likely to detonate. In the first place, an unconfined cloud would not be homogeneous or stoichiometric. Recent experiments of Bull et al. (Ref. 9-6) show that deviations from a stoichiometric mixture by 15 percent toward the lean side or 55 percent toward the rich side increase the mimimum charge required for initiation by a factor of 3, for ethane-air mixtures. (Presumably, similar factors hold for methane-air mixtures, which were not tested because of the larger charges required.) Secondly, the initiation sources available to an LNG cloud must be considered in detail, since it is not likely that high explosives would be included. More likely would be electric sparks and bursting gas bottles, but these would seldom release as much energy as 
rapidly as a kilogram of high explosive. Hence such sources, as well as others like pilot lights, would at most start a fire. In past balloon and spill tests that were ignited, no tendency for the flame to accelerate toward a detonation has been observed, and the flame velocities have remained over two orders of magnitude below the detonation velocity. Laboratory experiments suggest that obstacles in the flame path may accelerate the flame significantly, as discussed below, but in an unconfined region acceleration all the way to a detonation seems very unlikely.

A somewhat more likely mechanism of detonation initiation involves a two-step process, where a fire starts in a nearlyclosed structure, such as a large pipe, tunnel, or heavywalled room, and builds up enough pressure and velocity to cause a detonation front or a fast gas jet to emerge from an opening and initiate detonation in the cloud outside. Transitions from deflagration to detonation have been observed for a mixture of air with natural gas ( 8 percent ethane) in a 0.6-m diameter pipe (Ref. 9-7), and with pure methane in a 4.9-m water tunnel (Ref. 9-8). Such transitions occur only when the tube is large enough and ignition occurs near a closed end; they require a tube length of 50 to 150 diameters or more. Very recently Lind has demonstrated, in a stoichiometric mixture of air with 94 percent methane/6 percent propane, that a detonation started in a $2.4-\mathrm{m}$ diameter pipe (by high explosive at the closed end) propagated out the other end and caused the same mixture in a $20-\mathrm{m}$-diameter hemispherical bag around the end to detonate.* (A mixture containing 15 percent propane also detonated, but pure methane did not.)

In laboratory experiments using acetylene-oxygen mixtures, Lee and coworkers have shown that a hot turbulent gas jet

*Discussion with C.D. Lind, Naval Weapons Center, November 2, 197 
generated by combustion in a container with a single opening can initiate detonation in the gas outside, if the opening is partly covered by a grill having holes or slots of roughly the size of a "detonation kernel" in the mixture (Ref. 9-9). For LNG vaporair mixtures, this size would be a few centimeters to perhaps a meter, depending upon the fuel/air and ethane/methane ratios. In the area near an LNG storage tank such an arrangement might be formed by a heavy-walled chamber with a grill or several paralled pipes over or near its opening.

Destructive overpressures may be produced even without a detonation. A rapid deflagration, with a burning velocity (with respect to the unburned gas) of $35 \mathrm{~m} / \mathrm{s}$ or more, can produce destructive overpressures outside a spherical or hemispherical cloud (Ref. 9-10). However, the vapor cloud from a large LNG spill is much broader than it is high, so somewhat larger burning velocities are doubtless required to produce damaging overpressures (horizontally) outside the cloud.

In experiments with methane-air mixtures in large balloons, Lind (Ref. 9-11) observed flame speeds of 5 to $9 \mathrm{~m} / \mathrm{s}$. However, in a flame burning outward from an ignition point, the flame motion is mostly due to the expanding hot gases pushing the unburned gases outward, while the actual burning velocity is only one-seventh of the flame speed or about $1 \mathrm{~m} / \mathrm{s}$ in Lind's experiments. In ING spill tests where the vapor cloud was ignited near its downwind end, the upwind flame speed with respect to the wind was observed to be about twice the wind speed for winds up to $7 \mathrm{~m} / \mathrm{s}$, as shown in Figure 9-2. To convert the speed to a burning velocity, it should be divided by a factor somewhat less than 7 , since in this geometry the burned gases can also expand backwards and upwards. In laboratory experiments on laminar flames burning horizontally through flat fuel-air clouds, the factor was found to vary between 3 and 6 (Ref. 9-13).

The observed increase in burning velocity with wind speed is doubtless due to the increased level of atmospheric turbulence 


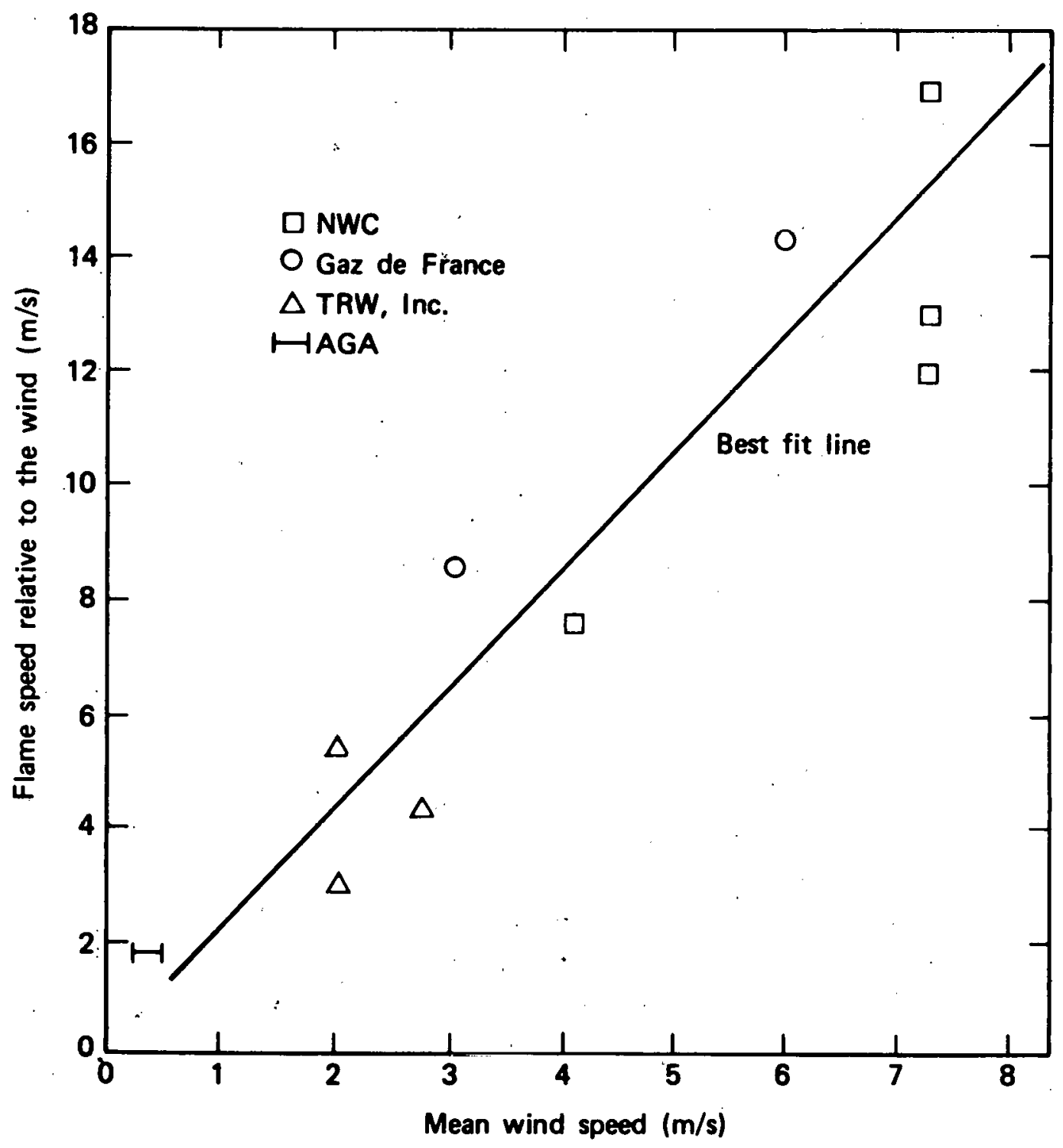

Note: The actual burning velocity (with respect to the gas just ahead of the flame) is smaller than this speed by an uncertain factor (see text).

Figure 9-2. Turbulent flame speed (with respect to the wind) observed on LNG test spills when the vapor cloud was ignited near the downwind end (from Ref. 9-12). 
at the higher wind speeds. Using a small fan in a laboratory chamber Bradley obtained burning velocities up to $10 \mathrm{~m} / \mathrm{s}$ at high turbulence levels (Ref. 9-14).

The field tests shown on Figure 9-2 were carried out on relatively smooth ground without structures, while laboratory experiments show that obstacles can considerably increase turbulent burning velocities. Lee and colleagues found that the burning velocity of a methane-air flame between two parallel disks could be increased up to at least $18 \mathrm{~m} / \mathrm{s}$ by putting regularly spaced obstacles in its path (Ref.9-15). In the case of a large accidental LNG spill a similar situation might arise if the vapor cloud drifted into a parking structure containing a number of cars. Also;. some ING tanks are supported about $1 \cdot \mathrm{m}$ off the ground by a large number of posts (although it is difficult to conceive of a fire starting in the center of this space). A somewhat similar geometry, but without the "lid", might be exhibited by vehicles in a parking lot, trees in a park, or even arrays of small buildings in some industrial or residential areas. The flame acceleration in such a more open geometry will doubtless be less, but no tests of this geometry have been made.

In addition to determining whether a vapor cloud will detonate or deflagrate, and with what speed, one must also. determine the strength of the pressure wave it produces. For a spherical cloud ignited at the center, or the equivelant case of a hemispherical cloud on a flat surface, the situation is spherically symmetric (neglecting buoyancy) and relatively simple; mathematical solutions and some measurements are available in the literature. However, as mentioned earlier, the vapor cloud from a large LNG spill is much wider than it is high, which is expected to make an important difference in 
the pressure wave. No measurements of the pressures produced outside such a burning cloud have been publișhed. Williams (Ref. 9-16) gave an approximate relation for the strength of the shock wave produced bỳ; a flame moving out from the center of a cylindrical cloud of finite height. However, this relation involves an "efficiency factor" whose magnitude is uncertain, especially when the cloud is much wider than it is high, so it cannot be relied upon to better than an order of magnitude. Lee et al. (Refs. 9-17,9-18) derived a simple approximate method for calculating the blast wave from the detonation of an ellipsoidal cloud, and presented results for a major/minor axis ratio of 2. Their approximations, however, are probably poor for much flatter ellipsoids. Very. recently, Sichel and Foster (Ref. 9-19) calculated and also measured the pressure decay behind a detonation wave moving horizontally through a flat cloud, and got good agreement. However, they did not extend the analysis or measurements beyond the edge of the cloud. Moreover, both their analysis and that of Lee et al. treated only detonations, which are simpler than deflagrations because the pressure at the detonation front is known (given by the Chapman-Jouget relation) and the gas ahead of the front is undisturbed. In addition, during a deflagration through a very large vapor cloud the buoyant combustion products have time to rise a large distance, which may affect the pressure wave produced by the deflagration.

To summarize the current state of knowledge on possible LNG vapor-air explosions, research has shown that detonations may be produced in such effectively-unconfined mixtures if they are homogeneous and stoichiometric, but it takes a large amount (kilograms) of high explosives to initiate such detonations, especially if the percent of ethane and propane in the LNG is small. However, research has not established the amount of high explosive required to initiate detonation in an actual unconfined vapor cloud produced by an LNG spill, which would 
be inhomogeneous and generally nonstoichiometric. Also unknown are the parameters of a lightning stroke, electric spark or bursting gas bottle which would make it powerful enough to detonate either a homogeneous or inhomogeneous vapor-air mixture.

It has been shown that when a natural gas-air mixture is contained in a large pipe or tunnel, a flame started near a closed end can run up into a detonation. However, the minimum pipe diameter and length required, and how these dimensions vary with mixture composition and homogeneity, are not known. The effects on this transition to detonation of a small opening in the pipe near the ignition point (which would permit ignition by an external fire) are also unknown. Tests have demonstrated that a detonation emerging from the open end of a large pipe can propagate through an effectively unconfined LNG vapor-air cloud, but they have not shown how the minimum pipe diameter depends upon the mixture composition and homogeneity.

Laboratory experiments have shown that combustion of a gas in a container with a grilled opening can produce a hot jet strong enough to initiate detonation in some explosive mixtures outside the container, but the parameters of a container and grill adequate to initiate an LNG vapor cloud are not well established. Small experiments have also shown that obstacles can greatly increase flame velocities, but there is insufficient information to make even a rough estimate of the increase that would be produced by the type of surface obstacles likely to be found near an accidental LNG spill. The limited number of vapor-cloud fire tests over smooth ground show a flame speed increasing linearly with increasing wind speed, up to $7 \mathrm{~m} / \mathrm{s}$, but it is not known whether this increase would continue up to the higher burning velocities required to produce damaging overpressures. 
Good measurements and/or theoretical calculations have been made for the pressure wave produced by the detonation or deflagration of a centrally-ignited spherical vapor cloud. However, no measurements are available for the pressures outside of detonating or deflagrating flat clouds like those produced by LNG spills, and the only published theory (for a deflagrating cloud) is crude and gives only order-of-magnitude results.

Outlined below is a research program designed to determine whether any of the objects or structures that might be found in the vicinity of LNG facilities or carrier berths could initiate, in the vapor cloud formed by a large accidental spill, either a detonation or a deflagration rapid enough to produce significant overpressures outside the cloud. We suggest that an overpressure of 0.07 bar ( 1 psi) be considered significant. This overpressure will break most windows but will not cause serious structural damage to residential-type construction. If such overpressures or greater should prove possible, a second goal would be to establish to within \pm 20 percent the overpressures produced outside a given vapor cloud, with ignition at a given point.

The approach recommended below is weighted toward the experimental, since many of the combustion phenomena involved are very difficult to model correctly theoretically. However, some mathematical modeling is included for experimental guidance and to help extend the test results to full-scale cases.

\section{RECOMMENDED RESEARCH ON DETONATION}

a. Preliminary considerations--It is convenient to divide the explosion research tasks into those concerned with detonation initiation and propagation in an unconfined LNG cloud, discussed in this subsection, and those concerned with the rapid deflagration of such a cloud, discussed later. (Deflagration initiation by a pilot light, small spark, etc., 
is physically so easy that it is not treated separately.) Detonation initiation by combustion in a pipe or chamber to produce a detonation wave or jet emerging from an orifice will be included in this subsection, even though the confined combustion may start as a deflagration.

Much LNG contains 10 percent or more ethane and a smaller amount of propane. The discussion in earlier sections indicates that after an LNG spill these components tend to boil off separately from the methane, and they may remain separate in the vapor cloud. Figure 9-1 (earlier in this section) shows that increasing the fraction of these heavier hydrocarbons in the cloud increases the ease of detonation initiation, with ethane being slightly more effective than propane. Accordingly, we recommend that each of the detonation initiation tests and calculations listed below be carried out first with pure ethane; if that detonates, then test 85 percent methane/15 percent ethane; if that detonates, then test pure methane. However, when and if the boiloff and vapor-dispersion tests described in earlier sections show that the methane and ethane vapors always $\mathrm{mix}$, the pure ethane tests should be omitted, while if they always remain separated the mixture tests should be omitted.

b.' Survey and analysis of potential initiation sources-At the outset of the research a comprehensive survey should be made of all existing potential initiation sources that might be found within the vapor dispersion range of LNG facilities and carrier berths. Examples of potential sources are condensed explosives, high-pressure gas containers (especially helium and hydrogen, which are efficient shock-wave drivers), storm drains, sewers, subways, highway tunnels, high-voltage lines, enclosed volumes in which combustion could produce strong jets through louvered openings, and any other objects that might contribute to detonation initiation. These potential sources should be physically described by recording 
shapes, dimensions, wall masses and strengths, storage pressures, etc. Analyses should then be conducted on each, to identify those most likely to have initiation potential. Lightning should also be analysed for the gas mixtures of interest. The survey and analyses should also seek to determine the number of the potential sources of all types that may exist in the area and the ways in which ignition or other modes of energy release might occur.

c. Tests of selected sources for characteristics relevant to detonation initiation-- When the survey and analysis described above has been completed, those sources for which uncertainties remain as to whether they could produce a shock, detonation or jet powerful enough to initiate an unconfined LNG vapor cloud should be tested in controlled experiments. These tests would be carried out without simulating the external cloud, to determine the characteristics of the emerging shock or jet before proceeding to the more-expensive largebag tests discussed below. If the shock or jet from a given source was not very strong, that source could be dropped from further consideration.

d. Homogeneous mixture experiments in bags--Using the initiators that passed the above tests, a series of experiments should then be conducted in large bags with the three fuel-air mixtures described earlier. These bags should be large enough in cross section to eliminate edge effects, and long enough to determine if detonation is sustained. For methane-air mixtures they should be about $3.5 \times .3 .5 \times 20 \mathrm{~m}$; for mixtures containing ethane they could be smaller.

e. Inhomogeneous mixture experiments in bags--Those sources which initiated detonations in homogeneous mixtures would then be tested in inhomogeneous mixtures confined in bags that are partitioned into a number of layers. Just before each test the partitions would be pulled out of the way. For 
most tests the fuel/air ratio in the different sections should be varied, but on a few the ethane/methane ratio could be varied. The extent of the variations and the thickness of the layers to be tested would be determined from the results of the vapor dispersion research described in section V.I and the detonation kinetics calculations described below.

f. 1-D hydrocode calculations with combustion kinetics-To help design the inhomogeneous mixture tests, and to increase our general understanding of the effects of inhomogeneities on detonation propagation, a set of 1-D spherical and planar calculations is recommended. First, a suitable code must be developed, which could be done rapidly by taking an existing NRL hydrocode (Ref. 9-20) that includes 43 reactions for hydrogen combustion and replacing these reactions with the 75 found by Westbook (Ref. 9-5) to give a good representation of methane and ethane combustion. (Probably the reaction list could be safely cut down, if necessary.). The code should then be checked by applying it, in spherical geometry, to several of the high-explosive tests in homogeneous methane-ethane mixtures performed by Bull et al. and by Lind, as mentioned earlier: (For checking the calculations on nearly pure methane, another 3 high-explosive tests are recommended, involving compact charges of about $10 \mathrm{~kg}$ in methane containing around 5 percent ethane, mixed stoichoimetrically with air.) After the code is checked, it should be applied (in plane geometry) to detonation propagation through layers of LNG vapor-air mixtures differing in thickness, fuel/air ratio and ethane/methane ratio. Emphasis should be placed on determining the limiting conditions where detonations barely propagate, within the range of . composition variations and thicknesses expected in unconfined vapor clouds. When better information on the cloud parameters becomes available from the tests recommended in section VI, further detonation calculations should be made if indicated. 
9. 2-D hydrocode calculations with combustion kinetics-Extension of the code discussed above to 2-D situations with cylindrical symmetry is also recommended. If done in time, this would provide predictions to help design experiments involving detonation propagation from the end of a pipe into an unconfined cloud, etc., discussed above in subsection IX.2.d. The code should later be checked by comparison with the results from such experiments, and then applied to other situations, including detonation propagation through (symmetric) inhomogeneities.

h. Field tests of unconfined vapor clouds from LNG spills-Since the question of detonation is complex, a few tests of detonability are recommended in vapor clouds produced by spills of $350 \mathrm{~m}^{3}$ of LNG on water, similar to those described for vapor dispersion experiments in section VI. These experiments would integrate all of the phenomena tested in plastic bags, and would use the results of wind tunnel tests and the preceeding $350 \mathrm{~m}^{3}$ vapor dispersion tests as guidance for placing and timing the initiators. The maximum combustible cloud would be sufficiently large in lateral dimensions $(200$ to $300 \mathrm{~m})$ and in height $(7$ to $10 \mathrm{~m}$ ) to remove concern that it might be too small for such tests.

Since the tests would be expensive and since a large number of detonation attempts is needed for high confidence, about 25 initiators would be activated essentially simultaneously in each test. These initiators would be those that produced detonations in previous bag tests, and they would be distributed throughout the combustible volume of the cloud about $60 \mathrm{~m}$ apart. With careful initiator spacing and monitoring via pressure gages and overhead airborne cameras, both high-speed and normal speed, it would be established which initiators, if any, produced detonation and the extent of detonation propagation throughout the cloud. Repeat tests 
would be performed to provide an adequate statistical base. Five such tests are recommended, with a possible sixth for contingencies. Pressure instrumentation would be provided to measure any overpressure produced outside the cloud. A limited amount of instrumentation would be included on these tests to measure the liquid pool spreading and vapor cloud radiation.

i. Aerosol experiments in bags--One can conceive of situations in which an explosion of vapor from an LNG spill could violently disperse either the remaining LNG in the same tank or that in a neighboring tank, producing an aerosol of LNG droplets. Since aerosols of most fuels are known to be detonatable, it is desirable to determine if an LNG aerosol is more or less easily detonatable than a vapor-air mixture. To obtain the answer, a set of experiments is recommended in which large bags would be filled with an LNG aerosol produced by a spray nozzle or other device, and tested for detonation. The same bags and types of initiators should be used as in the vapor-air experiments discussed in subsection IX.2.d (above), but the initiators should be slightly smaller or weaker than those required to detonate a gaseous mixture of the same composition. If these produce detonation in the aerosol, they should be made still smaller, to determine the lower size limit for initiating LNG aerosol detonations.

j. Unconfined aerosol tests--If the bag tests described above show that aerosols are more easy to detonate than vaporair mixtures, some tests should be made on unconfined aerosols. In these tests LNG in a container would be dispersed by an explosive charge and initiated by a second charge, using the well-established fuel-air-explosive technique. A few such tests have been carried out by Sandia corporation* without

*Discussion with W. Uncapher, Sandia Corporation, June 13, 1979. 
achieving detonation, but they employed only about $0.02 \mathrm{~m}^{3}$ of LNG, which produced a cloud $6-8 \mathrm{~m}$ in diameter and probably 2 - $3 \mathrm{~m}$ high; a height marginal for supporting detonation in methane-air mixtures. Tests of aerosol clouds at least; twice this diameter and height are needed.

\section{RECOMMENDED RESEARCH ON RAPID DEFLAGRATION}

a." Preliminary considerations--In contrast to LNG detonation tests, where it is believed that tests above a certain critical size (which depends upon the geometry and the mixture composition) give essentially the same results as much larger tests, for deflagration tests the burning. velocities and buoyancy effects may continue to increase with size up to sizes much larger than it is practical to test. Accordingly, in the deflagration research program more reliance must be placed on mathematical models to extrapolate test results to situations involving larger LNG spills.

b. 2-D hydrocode calculations with turbulence and flame propagation--It is important to develop a 2-D hydrocode that includes buoyancy, an adequate model of turbulence, and a flame model based on an empirical relation between the burning velocity and the turbulence parameters (see below). Such a code can be based on the improved 3-D hydrocode described in Section VI, Table 6-13, but reduced to 2-D and augmented by a simple flame model. A code similar to that recommended here has been developed at Lawrence Livermore Laboratory and employed to calculate the combustion of large cylindrical LNG vapor clouds (Ref. 9-21). However, the simple turbulence model employed in the Livermore code may not be adequate. A twoequation $k-\varepsilon$ model is preferable, as discussed in subsection VI. 5.a.

The recommended hydrocode 'would employ an empirical relation for the burning velocity as a function of the local turbulence 
parameters, based on the experiments described below. As results become available, first from the laboratory experiments, then from the larger partially-confined and bag tests, and finally from the large spill tests, this relation should be continually improved. The code would be used to predict the combustion of the centrally-ignited clouds from the spill tests, and the turbulence and/or flame models adjusted if required to obtain agreement with the test results. The final version would then be used to make predictions for large accidental spills. The code calculations would generally include a computation of the overpressures in the region surrounding the cloud. However, if the burning velocity ever became high enough to produce damaging overpressures more than 2 cloud radii away from the center, it might be more efficient to use a separate nonturbulent code to calculate the pressure-wave propagation at a distance from the cloud.

c. Burning-velocity experiments--In order to derive an empirical relation between the burning velocity and the turbulence parameters in LNG vapor-air mixtures, further experiments like those of Bradley (Ref. 9-14) and Lee (Ref. 9-15), but in larger apparatuses, are needed. An effort should be made to vary a variety of parameters, so that the results apply to a large range of sizes and geometries. The results should then be reduced to an empirical formula convenient for use in the 2-D code.

d. Partially confined tests with turbulence--Because of their practical importance, deflagration tests are recommended on stoichiometric LNG vapor-air mixtures in full-scale mockups of two relevant structures. These include the region between the ground and the bottom of an LNG tank supported on posts, and the annular region between a tank and a high dike. The openings of these mockups should be covered with thin plastic, to allow filling with a uniform gas mixture, and ignition 
should be at the center on some tests and at the edge on others. In the tank-bottom tests the combustion-induced flow around the posts is probably sufficient to produce strong turbulence. In the high-dike tests, consideration should be given to including one or more large fans to simulate the flow induced by the wind blowing across the dike top. Other structures, such as a narrow gap between two buildings, might also be simulated. The structures to be tested and the placement of obstacles, fans and ignition points should be determined with the help of the burning experiments and calculations described earlier, and possibly some small-scale model tests.

e. Bag tests with turbulence--Deflagration tests should also be carried out with stoichiometric mixtures in large flat cylindrical bags that contain obstacles and/or fans to produce turbulence. The first tests should employ central ignition; if these produce significant overpressures, side ignition should also be tried.

f. Field tests of vapor clouds from LNG spills--The final set of tests would involve ignition of the vapor clouds from test spills of $350 \mathrm{~m}^{3}$ of LNG on water. The recommended tests are listed in Table 9-1, along with the five field tests for detonability described earlier. The first deflagration test would be on relatively smooth ground in a high wind, since the latter tends to maximize the burning velocity (see Figure 9-2). The next three tests would emphasize the effects of obstacles, including not only arrays of objects. in the open, but also some in a roofed "parking structure." Finaliy, five contingency tests are included to permit repetition of any of the previous tests that seem particularly significant or for which some of the instrumentation failed, or performance of new tests suggested by the previous results. For example, if the "parking structure" tests fail to give significant over- 
TABLE 9-1. RECOMMENDED EXPLOSION TESTS ON LNG

VAPOR CLOUDS FROM LARGE TEST SPILLS.

NOTE: All tests involve unconfined spills of $350 \mathrm{~m}^{3}$ of LNG on water, with ignition or initiation near the time that the flammable region reaches its maximum size.

\begin{tabular}{|c|c|c|c|}
\hline $\begin{array}{l}\text { Test } \\
\text { no. }\end{array}$ & $\begin{array}{l}\text { Wind } \\
\text { speed }\end{array}$ & Ignition/Initiation & Terrain conditions \\
\hline $1-5$ & $\begin{array}{c}\text { Low } \\
\text { or } \\
\text { moderate }\end{array}$ & $\begin{array}{l}\text { Sets of } 25 \text { strong initiators, } \\
\text { spaced over the predicted } \\
\text { flammable region and set off } \\
\text { simultaneously }\end{array}$ & Relatively smooth \\
\hline 6 & High & Flare at centroid of cloud & Relatively smooth \\
\hline $7-8$ & $\begin{array}{l}\text { Low; } \\
\text { high }\end{array}$ & $\begin{array}{l}\text { Flare at center of "parking } \\
\text { structure" }\end{array}$ & $\begin{array}{l}\text { Array of obstacles } \\
\text { similar to cars in } \\
\text { a parking struc- } \\
\text { ture, plus arrays } \\
\text { of truck- ilike ob- } \\
\text { jects and other } \\
\text { obstacles }\end{array}$ \\
\hline 9 & $\begin{array}{l}\text { Repeat } \\
\text { overpres }\end{array}$ & $\begin{array}{l}\text { f test } 6 \text { or } 7 \text {, whichever gave the } \\
\text { sures. }\end{array}$ & highest \\
\hline $10-14$ & $\begin{array}{l}\text { Continge } \\
\text { the test }\end{array}$ & $\begin{array}{l}\text { ncy tests, parameters to be deter } \\
\text { program. }\end{array}$ & mined during \\
\hline
\end{tabular}


pressures, a more-closed structure could be tested, while if they give large overpressures, removal of the roof or ignition from the side should be considered.

The instrumentation recommended for these tests consists of the pressure sensors and movie cameras mentioned in connection with the detonation tests, plus all of the instruments recommended in Section VIII for vapor-cloud fires. The latter includes sensors to measure the unburned vapor concentration (to determine the cloud position before ignition), sensors to detect the flame-front passage, and the full array of radiation and liquid-level instruments discussed previously (see Section VII, Table 7-2). Thus, these explosion tests will provide additional information on flame radiation and on LNG spreading and boiloff, unless financial or operational constraints prevent such measurements from being cost-effective.

\section{EXTENDED PROGRAM}

If a more complete and longer research program is desired, in order to cover a wider variety of potentially explosive configurations and give greater confidence to the conclusions, each of the experimental and mathematical tasks described above should be expanded by the repetition of some tests and the addition of other tests and calculations for different mixture compositions, wind speeds, ignition positions, detonator sizes, etc. Also recommended is the extension to 3-D of the 2-D hydrocode with combustion kinetics (for detonation) and the 2-D hydrocode with turbulent flame propagation, and the application of these codes to nonsymmetric situations of practical interest. Finally, consideration should be given to whether a code incorporating both turbulence and combustion kinetics in a realistic fashion could be developed and applied in the next five years, at a nonexorbitant cost. If so, such a code development program should be supported. 
9-1. Bull, D. C., Elsworth; J. E., Hooper, G., and Quinn, C. P., "A study of Spherical Détonation in Mixtures of Methane and Oxygen Diluted by Nitrogen," J. Phys. D., vol. 9, 1976, pp. 1991-2000.

9-2. Bull, D. C., Elsworth, J. E., and Hooper, G., "Initiation of Spherical Detonation in Hydrocarbon-Air Mixtures," Acta Astronaut.: Vol'. 5, 1978, pp. 997-1008.

9-3. Bull, D. C., Elsworth, J. E., and Hooper, G., "Susceptibility of Methane-Ethane Mixtures to Gaseous Detonation in Air," Combust.'Flame, Vol.' 34, 1979, pp. 327-330.

9-4. Benedick, W. B., "High-Explosive Initiation of MethaneAir Detonations," Combust. Flame, Vol. 35, 1979, pp. 89-93.

9-5. Westbrook, C. K., "An Analytical Study of the ShockTube Ignition of Mixtures of Methane and Ethane," Combust. Sci. Tech., Vol. 20, 1979, pp. 5-17.

9-6. Bull, D. C., Elsworth, J. E., and Hooper, G., "Concentration Limits to Unconfined Detonation of Ethane-Air," Combust. Flame, Vol. 35, 1979, pp. 27-40.

9-7. Gerstein, M., Carlson, E. R., and Hill, F. U., "Natural Gas-Air Explosions at Reduced Pressure," Ind. Eng. Chem., Vol. 46, 1954, pp. 2558-2562.

9-8. Nicholls, J. A., Testimony on the Port Huron Water Tunnel Explosion Case, Wayne County Circuit Court, June 16-17, 1975.

9-9. Knystautas, R., Lee, J. H., Moen, I., and Wagner, H. Gg., "Direct Initiation of Spherical Detonation by a Hot Turbulent Gas," Seventeenth Symp. (Internat.) on Combustion, Combustion Institute, Pittsburgh, PA, 1979, pp. 1235-1245.

9-10. Oppenheim, A. K., Kurylo, J., Cohen, L. E., and Kamel, M. M., "Blast Waves Generated by Exploding Clouds," Shock Tube and Shock Wave Research, Proc. Eleventh Internat. Symp. on Shock Tubes and Waves, Univ. of Washington Press, Seattle and London, 1978, pp. 465-473. 
REFERENCES FOR SECTION IX

(CONTINUED)

9-11. Lind, C. D., and Whitson, J. C., Explosion Hazards

Associated with Spills of Large Quantities of Hazardous Materials, Phase II, U.S. Coast Guard, Report CG-D-85-77, November 1977.

9-12. Raj, P.P.K., et al., Experiments Involving Pool and Vapor Fires from Spills of Liguefied Natural Gas on water,

A. D. Little, Inc., Report No. 82404, March 1979 .

9-13. Kapstein, M., and Hermance, C.E., "Horizontal Propagation of Laminar Flames through Vertically Diffusing Mixtures above a Ground Plane," Sixteenth Symp. (Internat.) on Combustion, Combustion Institute, Pittsburgh, PA,-1977, pp. 1295-1306.

9-14. Abdel-Gayed, R. G., and Bradley, D., "Dependence of Turbulent Burning Velocity on Turbulent Reynolds Number and Ratio of Laminar Burning Velocity to R.M.S. Turbulent Velocity," Sixteenth Symp. (Internat.) on Combustion, Combustion Institute, Pittsburgh,. PA, 1977, pp. 1725-1735.

9-15. Moen, I. O., Donato, M., Knystautas., R.,...ànd Lee J. H., "Flame Acceleration due to Turbulence Produced by obstacles," Combust. Flame, Vol. 39, 1980, pp. 21-32.

9-16. Williams, F. A., "Qualitative Theory of Nonideal Explosions," Combust. Sci. Tech., Vol. 12, 1976, pp. 199206 .

9-17. Lee, J. H., Guirao, C. M., Chiu, K. W., and Bach, C. G., "Blast Effects from Vapor Cloud Explosions," Loss Prevention, Vol. 11, 1977, pp. 59-70.

9-18. Chiu, K. W., Lee, J. H., and Knystautas, R., "The Blast Waves from Asymmetrical Explosions," J. Fluid Mech., Vol. 82, 1977, pp. 193-208.

9-19. Sichel, M., and Foster, J. C., "The Ground Impulse Generated by a Plane Fuel-Air Explosion with .Side Relief," Acta Astronaut., Vol. 6, 1979, pp. 243-256.

9-20. Oran, E., Young, T., and Boris, J., "Application of TimeDependent Numerical Methods to the Description of Reactive Shocks," Seventeenth Symp. (Internat.) on Combustion, Combustion Institute, Pittsburgh, PA, 1979, pp. 43-54.

9-21. Hogan, W. J., Bowman, B. R., and Haselman, L. C., "Numerical Modeling of LNG Spill Phenomena," Lawrence Livermore Laboratory, Preprint UCRL-82031, Dec. 13, 1978. 


\section{PRELIMINARY COST ESTIMATE AND TIME SCHEDULE}

\section{SUMMARY OF COSTS}

A preliminary cost estimate is given in Tabie 10-1 and is broken down into eight categories.' The cost.given for each of these categories is enlarged on in the following subsection. In addition, further cost breakdowns and backup material are available at $R$ \& D Associates. All costs are in 1979 dollars.

TABLE 10-1. SUMMARY OF ESTIMATED COSTS

\begin{tabular}{|lc|}
\hline \multicolumn{1}{|c|}{ ITEM } & $\begin{array}{c}\text { COST } \\
(\$ 1,000)\end{array}$ \\
\hline Program management and support & 3,738 \\
Parametric line-source experiments & 200 \\
Flame-speed experiments & 610 \\
Swimming pooi tests & 389 \\
Smali wind tunnel tests & 338 \\
Large wind tunnel tests & 537 \\
Explosion tests & 623 \\
Large-scale field tests & 14,368 \\
TotAL & $\$ 20,803$ \\
\hline
\end{tabular}

2. INDIVIDUAL COST ESTIMATES

a. Program management and support--This category includes salaries for overall program management and administrative support, mathematical analysis, and test planning and design work. Also included are monies for technical consultants and laboratory-scale experiments. Management and data reduction 
costs for the individual subprograms are included in the respective category estimates.

$\begin{array}{lc}\text { Program Management } & \$ 465 \mathrm{~K} \\ \text { Mathematical Modeling and Analysis } & 1600 \\ \text { Engineering Test Planning and Design } & 390 \\ \text { Administrative Support } & 195 \\ \text { Consultants/Laboratory Experiments } & \frac{600}{\$ 3250 \mathrm{~K}} \\ \text { 15\% Contingency } & \frac{488}{\$ 3738 \mathrm{~K}}\end{array}$

b. Parametric line-source experiments--These experiments would be accomplished as a research project at a research organization or university. Facilities required would be a small wind tunnel plus instrumentation. It is estimated that $\$ 200,000$ would cover the total cost including data reduction and reporting.

c. Flame-speed experiments-This task would be carried out by a research organization over a period of 1 to $11 / 2$ years. The major costs are based on the construction of a 10-ft explosion-proof tank and associated gas-charging equipment and diagnostics. An estimate of $\$ 610,000$ will cover these experiments.

d. Swimming pool tests--The cost of this task is based on the use of an existing Navy-built pool near Albuquerque, New Mexico. This pool is $200 \mathrm{ft} \times 150 \mathrm{ft}$ and is already equipped with pumping and filtration equipment. The major items required for site preparation are the relining of the pool and the construction of the overhead camera and spill tank support. An LNG tank trailer would be used for on-site LNG storage, thus eliminating the necessity for permanent storage facilities. This. tank trailer would also be used at the field-test site and its 
cost is accounted for there. Instrumentation would be government-furnished or shared with the large-scale field tests and is accounted for under that category.

Pexsonnel

Site Preparation and Equipment

Data Reduction and Reporting

15 을 Contingency
$\$ 163 \mathrm{~K}$

69

$\frac{106}{\$ 338 K}$

51

e. Small wind tunnel tests--These tests would be perperformed at an existing facility such as the one at colorado State University. The major facility preparation items are the design and fabrication of a flow temperature and humidity control system and a vápor release mechanism. Instrumentation would be largely facility-furnished.

Personnel

$\$ 116 \mathrm{~K}$

Facility Preparation and Equipment 51

Data Reduction and Reporting 127 $\$ 294 \mathrm{~K}$

158 Contingency $\frac{44}{\$ 338 \mathrm{~K}}$

f. Large wind tunnel tests--These tests would be performed in the new NASA Ames $37 \times 55-\mathrm{m}$ wind tunnel (see section VI, Figure 6-6), which will be equipped with its own data reduction and processing facility. All test equipment (models, sources, instrumentation, and test beds) would be prefabricated in modular form for quick assembly into the tunnel for a one-month period of actual testing. Assistance in model installation, tunnel operations, and data recording and reduction will be provided by NASA-Ames at no cost to the project. Much of the 
instrumentation used in these tests would be borrowed from the vapor-dispersion field tests and is accounted for under that section.

Personnel $\$ 140 \mathrm{~K}$

Model and Tunnel Preparation and Equipment

Data Reduction and Reporting $\frac{127}{\$ 467 \mathrm{~K}}$

$15 \%$ Contingency $\frac{70}{\$ 537}$

g. Explosion tests--These are series of field tests, utilizing premixed vapor rather than liquid spills, whose major costs will be in site preparation and data reduction. Instrumentation will be government-furnished or shared with the large-scale field tests. Total test time should not exceed four months.

Personnel

Site Preparation and Equipment

Data Reduction and Reporting

$15 \%$ Contingency
$\$ 73 \mathrm{~K}$

$\frac{278}{\$ 542 \mathrm{~K}}$

81

$\$ 623$

h. Large-scale field tests--The large-scale field tests are assumed to be located on Frenchman Lake at the Nevada Test Site, shown in Figure 10-1. These tests consist of LNG spills on land and water for investigating pool fires, vapor-cloud fires, and explosions. The test area would consist of two sites served by a common remote data-gathering center. This center would be temporary in nature, consisting of governmentfurnished recording and instrumentation trailers placed behind a protective earth berm. It is assumed that these trailers 


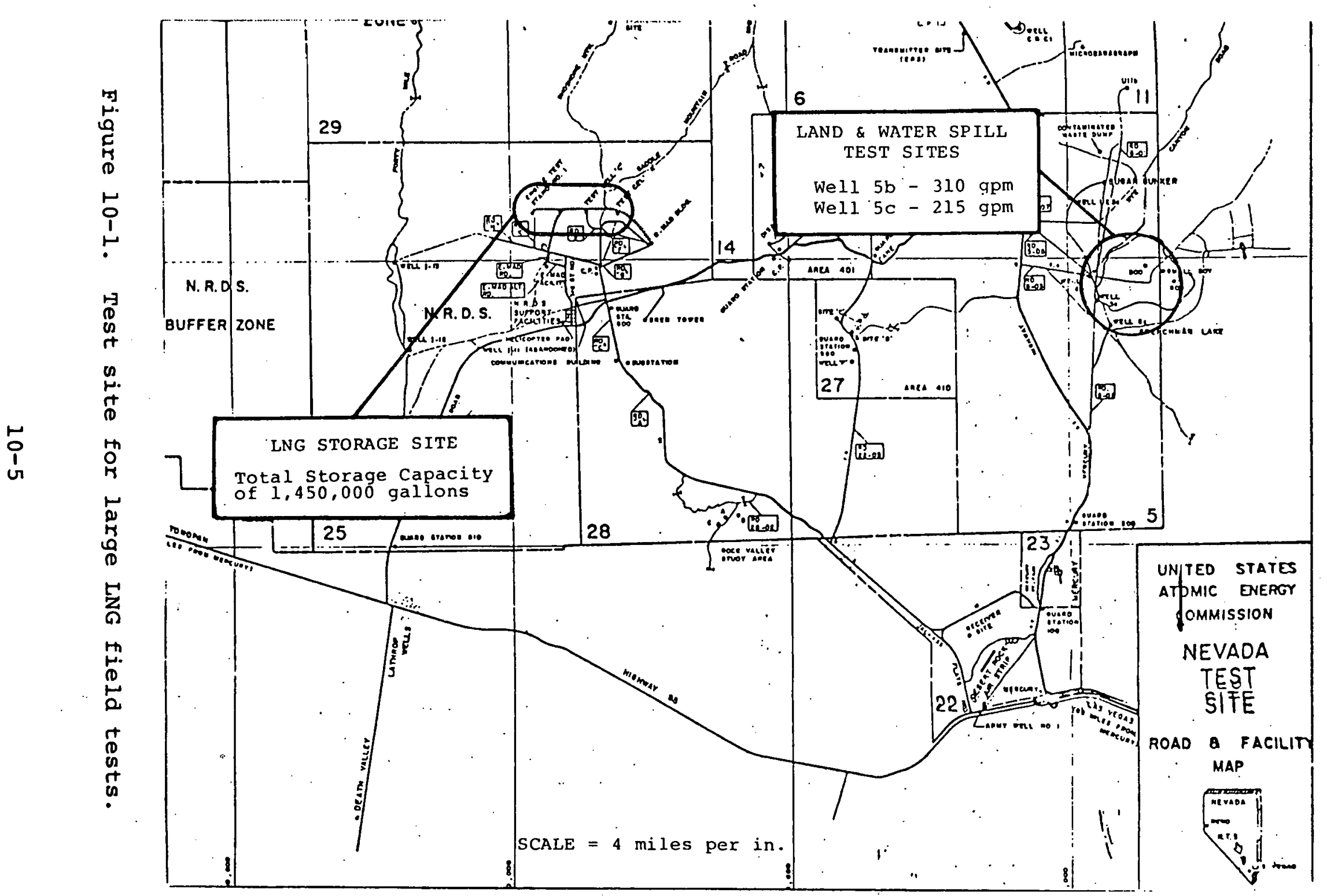


and data-recording instruments would be provided at no cost to the project with only minimal modifications required. Costs for all instrumentation including that which is shared with other sites is included here. Additional instrumentation costs for flame-radiation measurements and airborne camera coverage to be provided by outside contractors are included in the instrumentation figure presented below.

Spill tanks at the test sites and the tanks to be used for LNG storage at the Nuclear Rocket Development Site (Jackass Flats) would be surplus tanks, which are known to be available. Cost estimates for obtaining, modifying, and erecting the two spill tanks and for refurbishing the storage tanks at the NRDS were obtained from Gibson Cryogenics, Inc., Lakeside, California. These estimates include all engineering, materials, and labor costs necessary for the refurbishment of the tanks to meet appropriate codes. Using surplus tanks represents a considerable savings over the fabrication of new tanks.

The water spill site is located at the low point in the dry lake bed. The lake is partially filled with water during part of the year. Low dikes would be built and a well drilled additional to existing wells to provide water during the dry season and to insure sufficient water depth for all tests.

For the complete series of tests, $3.85 \times 10^{6}$ gallons of LNG and an additional 200,000 gallons of liquefied ethane for enrichment are required. It is assumed this LNG would be commercially trucked in from San Diego Gas and Electric in Chula Vista, California, to the storage area at the NRDS. An LNG tank trailer purchased for this project will be used to transfer LNG from the storage area to the spill sites. The delivered cost of the LNG is listed. 
On-Site Personnel (including per-diem)

-Site Preparation and Construction

LNG Storage Tanks

Instrumentation

LNG and Ethane

Data Reduction and Reporting

158 Contingency
$\$ 2,392 \mathrm{~K}$

1,941

1,213

740

3,432

2,776

$\$ 12,494 \mathrm{~K}$

1,874

$\$ 14,368 \mathrm{~K}$

\section{TIME SCHEDULE}

An approximate time schedule for the research tasks recommended in this report is shown in Figure 10-2. It should be pointed out that the durations of the various tasks. indicated in this figure are not necessarily an indication of the sizes of the respective efforts, since some efforts are short but intense, while others extend longer but at a lower rate because they depend in part on information becoming available from other tasks. 


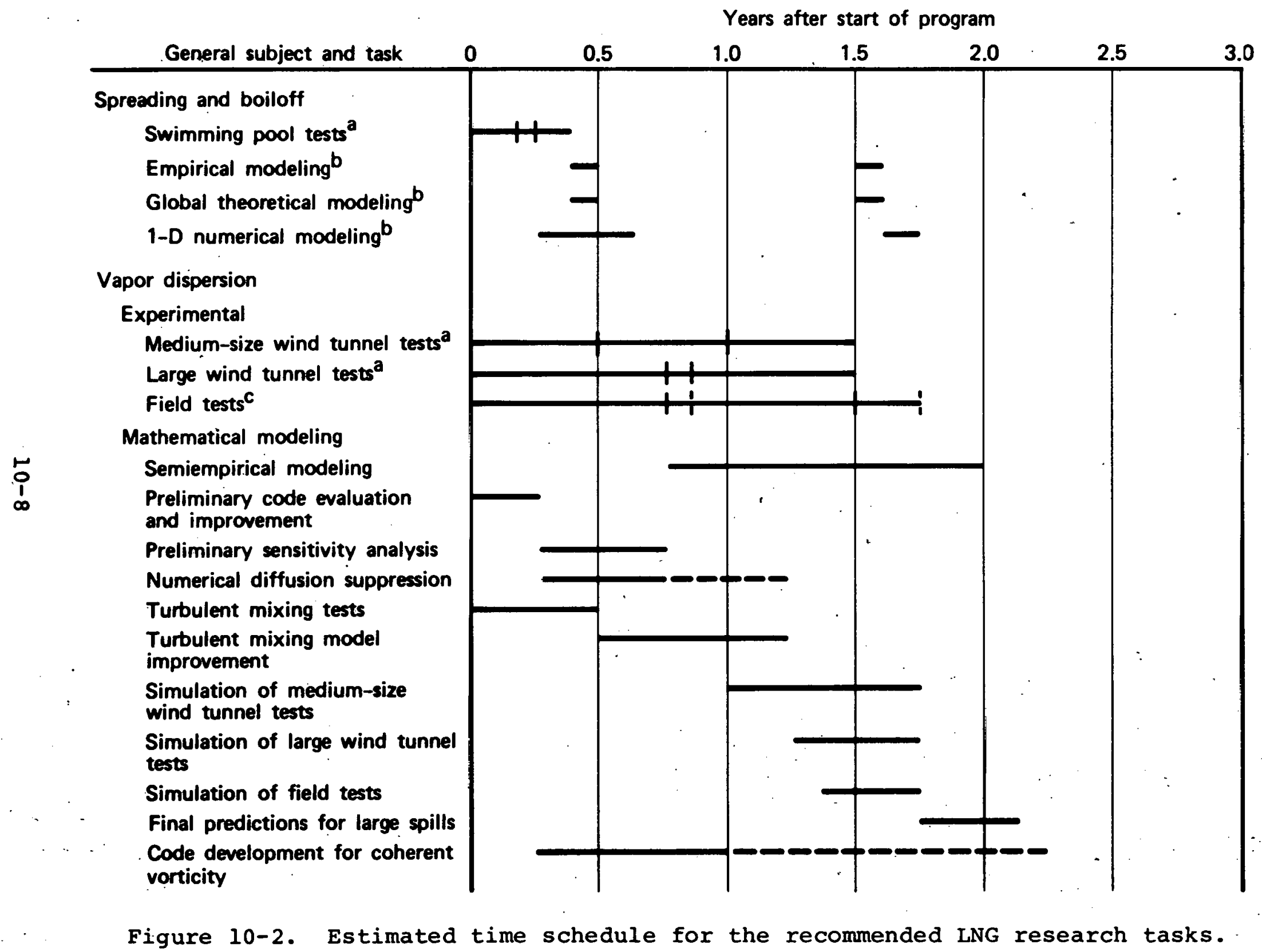




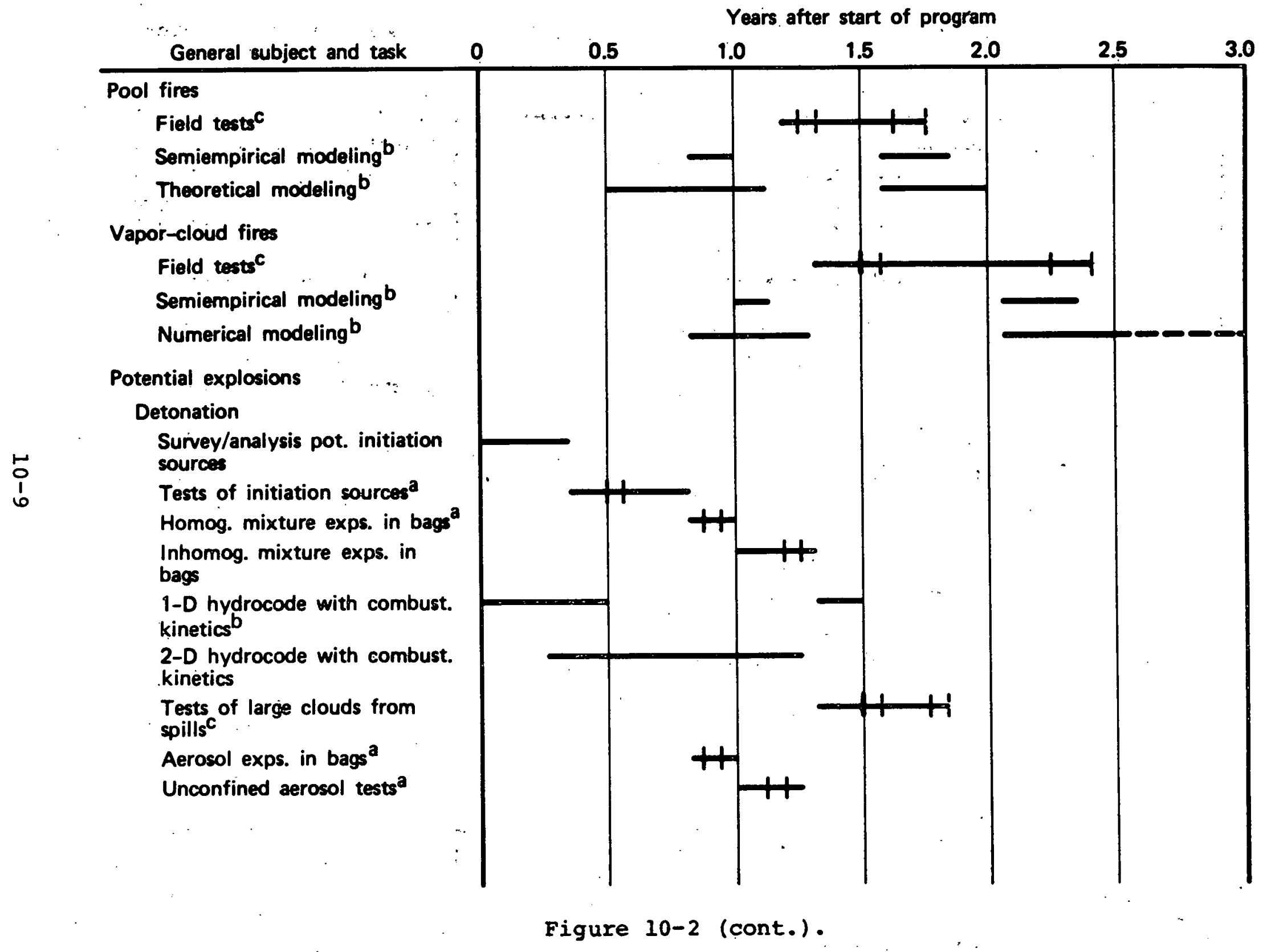




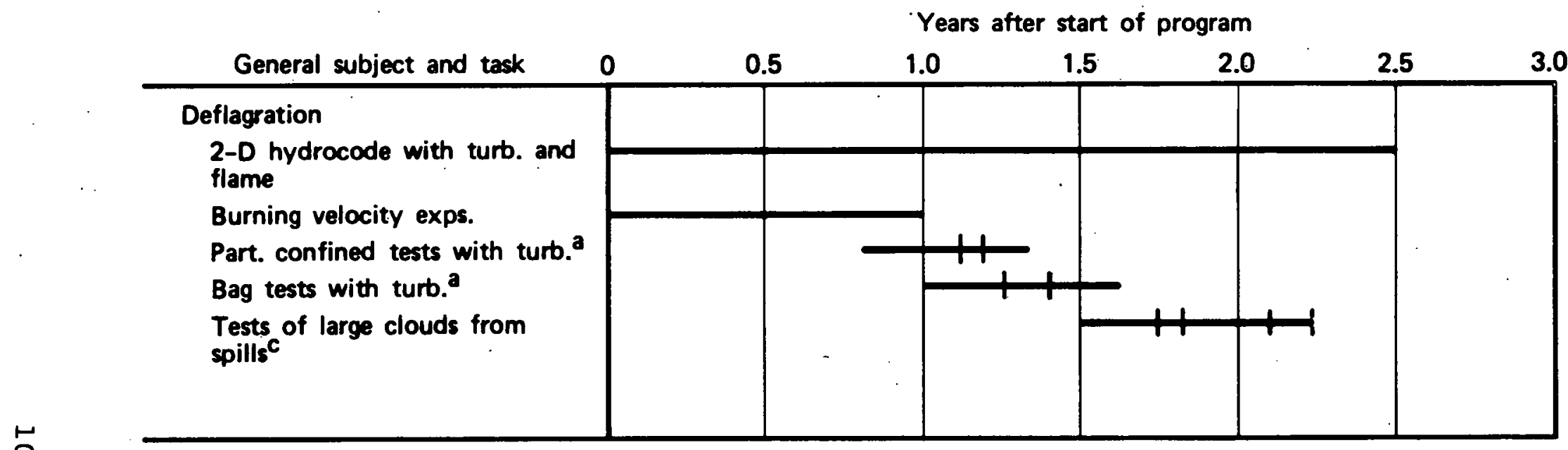

a The three segments shown on the bar graph for these tests represent the three successive phases: test preparation (design, fabrication, calibration, installation, etc.); testing; and data reduction, analysis, and report writing.

${ }^{b}$ These modeling efforts are broken into two segments, with an intervening inactive period while awaiting further relevant test data.

COn these field tests the data reduction and analysis period, shown by the bar section between the dotted markers, overlaps considerably with the testing period, shown by the section between the solid markers. Also, the testing periods for vapor dispersion, pool fires, etc. overlap, to allow switching around in accordance with the weather and the availability of equipment and personnel.

Figure 10-2 (concl.). 


\section{TECHNICAL REVIEWERS' COMMENTS AND OUR RESPONSE}

\section{INTRODUCTION}

By agreement with the DOE, a draft of this report, in almost its present form, was sent out for comments to 38 persons with experience or responsibility for LNG safety regulations or research, or scientific expertise in a directly relevant field. Written replies were received from five individuals: Dr. Elizabeth M. Drake (A.D. Little, Inc.), Dr. J. Reed Welker (Applied.Technology, Inc.); Prof. Jerry A. Havens (University of Arkansas), Prof. Robert N. Meroney (Colorado State University), and Lt. G. R. Colonna (U.S. Coast Guard), and collectively from two organizations: Battelle Pacific Northwest Laboratories and Lawrence Livermore Laboratory. Copies of their letters are reproduced in the Appendix. A number of the other report recipients were contacted by phone. Technical comments were made via telephone by 7 individuals: Prof. Forman A. Williams (UC San Diego), Dr. Henry Walter (DOE), Dr. Leonard C. Haselman (Lawrence Livermore Laboratory),. Dr. C. Douglas Lind (Naval Weapons Center), Dr. George Markștein (Factory Mutual Research Corp.), Dr. William Benedick (Sandia Laboratories), and Prof: James A. Fay (M.I.T.). Several others were unable to study the report in the time allotted because of summer travel plans or other commitments. A representative of the LNG industry stated that he and others were preparing for $D O E$ an $A G A$ response to our report, but we have not received a copy of this document.

Before summarizing the major written and oral comments and giving our responses to them, the authors wish to thank those who studied the draft report and communicated their suggestions. Thanks are also due for their pointing out several typographical errors and infelicities of language, which have been corrected in this final version of the report. 


\section{COMMENTS ON THE SUMMARY}

It is convenient to discuss the comments in the order of the report sections to which they refer, starting with the Summary. The only comments received on the summary were from Battelle Pacific Northwest Laboratories (see Appendix). The Summary. has since been replaced by an Executive Summary (at. the request of $\mathrm{DOE})$, so that it is now more logical to consider the three points raised by Battelle, concerning LNG release characteristics, desired prediction accuracy and maximum test spill size in the later discussion on LNG spreading and vapor dispersion.

\section{COMMENTS ON THE INTRODUCTION}

In the first full paragraph on page 1-2 of the Introduction, Battelle reviewers had difficulty in following the logic. This difficulty may now be alleviated by the change of the adjective "unpredictable" to "unanticipated," as suggested by H. Walter. We see no inconsistency in our intended implication that spill-prevention aspects are well founded, but that a large, low-probability accident might still occur, the consequences of which currently have large uncertainties.

\section{COMMENTS ON SECTION II (PERMIT PROCEDURES)}

In accordance with the relatively minor suggestions made on this section, a latin phrase on page 2-4 was converted to English and a paragraph on OPSR standards on page 2-13 was updated.

5. COMMENTS ON SECTION III (INFORMATION FOR REGULATORY PURPOSES)

On this subject, Battelle reviewers requested more details concerning the people contacted and the conclusions reached. Because many of the people involved were government or industry officials speaking unofficially, we did not feel it appropriate to identify them. Moreover, their opinions were so varied that 
it was difficult to draw more definite conclusions than those indicated on pages 3-12 to 3-16.

6. COMMENTS ON SECTION IV (GENERAL FEATURES OF THE RECOMMENDED PROGRAM)

Commenting on this section, Drake recommends that the research program concentrate on the smaller accidental spills that occur more often, the Battelie group believes that at least truck spills should be included, and the Livermore group feels that a wide range of spills should be covered. We still believe that the large spills are the critical public safety issue, and moreover that many aspects of smaller or more gradual spills can be fairly well predicted from past field and wind tunnel tests (see, for example, section.VI, Figures 6-1 and 6-7). Drake also criticizes the "rapid" program, and mentions the data limitations of the early AGA and recent China lake field tests. We feel that these limitations were due to inadequate instrumentation, and to spending so much effort on a number of small tests that insufficient time and money were left to do a good job on the planning and instrumentation of the large ones. The AGA vapor dispersion and fire tests involved a total of 31 six-foot (diameter) spills, 15 twenty-foot spills and 3 eighty-foot spills ( 1 ignited), yet the most practically useful data came from the few large spills, and many of the data from the smaller spills were not even reported. Considerably more useful information could have been obtained in less time and at the same cost by cutting the number of small tests drastically and doubling the number of eighty-foot tests.

Drake, Havens, Colonna and the Battelle reviewers suggest that we should have related our recommended program to the ongoing DOE/USCG program at the Naval Weapons Center (field tests), Colorado state University (wind tunnel tests), Livermore (theory and test planning) and Battelle (technical planning). We agree that a comparison would be useful. However, during 
the first part of our study little written material on the DOE/USCG program was available, and obtaining the relevant information by visits would have been time-consuming and not vital to our primary purpose, which was to provide independent recommendations for a research program. Later, more documents were published, but time and cost constraints prevented our adding a comparison of the research programs to this report. However, we believe that the China Lake tests, because of their limited spill size and spill rate, the special topography of the test site (the pond bank has a height significant compared to the vapor-cloud height; and the ground slopes upward away from the pond), and the insufficient instrumentation (at least on the tests conducted so far) will not answer the critical questions concerning large accidental spills. The Livermore analyses and suggested plans for largefield tests are closer to our recommendations, but we feel that their philosophy of gradually proceeding from small spills up to very large spills (perhaps $1000 \mathrm{~m}^{3}$ ) results in a program duration and cost considerably larger than is required to answer the high-priority practical questions.

7. COMMENTS ON SECTION V (LNG SPREADING AND BOILOFF)

On this subject, Drake questions the need for experiments because the China lake tests show that spreading and boiloff vary with the spill geometry and force (thus making any test results of specialized applicability), while vapor dispersion and pool fire estimates are fairly insensitive to the boiloff rate. We believe that in the water-spill situations most important for public safety, i.e., massive cargo tank ruptures and transfer line breaks, the spill geometry and force are reasonably well defined. A large tank rupture simply results in an outward LNG flow at a velocity corresponding to the hydraulic head in the tank, with relatively little downward velocity (in contrast to the China Lake experiments), while 
in a line break the LNG generally acquires a downward velocity corresponding to free fall from the height of the deck. Although we agree that vapor dispersion and fires are not very sensitive to the boiloff model, we believe that the current uncertainty of up to a factor of 7 in the boiloff rate per unit area on water (see p. 5-9) contributes an important uncertainty to predictions of the hazardous distance.

In response to the Battelle reviewers' comment about the need to understand LNG release mechanisms and characteristics, we point out that our recommended swimming pool tests include modeling of the releases for the high-priority : situations (massive tank rupture and transfer-line break).

We thank Dr. Welker for recommending bubbler systems for measuring boiloff rates, and the Battelle group for informing us of Hoult's differential boiloff model. The latter reviewers ask for justification of our statements on pages 5-9 and 5-12 that spreading and boiloff on land are sufficiently well understood; this justification was given earlier, on page 5-2. They also question our dismissal of the dike rupture problem; perhaps that problem deserves further consideration.

\section{COMMENTS ON SECTION VI (VAPOR DISPERSION)}

The greatest number of comments were made on this section. Many reviewers questioned the practical need and technical feasibility of our stated goal of developing techniques that permit the determination of the distance to a given mean LNG vapor concentration, for a specified LNG site, spill and weather, with an uncertainty of \pm 10 percent. Accordingly, after further consideration our accuracy goal has been relaxed somewhat, to \pm 15 percent. Also, a more detailed explanation of why we think this goal is desirable and probably attainable has been added to pages 6-5 and 6-6. 
Several reviewers questioned our reliance on Froude number scaling. It should be explained that we propose to match not only Froude numbers (including time-dependent ones), but also gas density ratios, by using actual LNG vapor in the wind tunnel and field tests. If one believes, as argued on pages 6-19 to 6-21, that heat transfer to the gas from the ground or other surfaces is negligible, and that the important phenomena are independent of Reynolds number (as long as the latter is large enough to produce fully developed turbulence), then the Froude number and the gas density ratio are the only remaining independent dimensionless quantities, and the dispersion phenomena cannot depend upon other (dimensional) factors or they would vary with the specific measurement units employed. (This is the basic principle of dimensional analysis; see Reference 11-1.) To verify the Froude number scaling (which is essentially equivalent to verifying that Reynolds number variations and surface heat transfer have negligible effects), our recommended research program includes a number of scaled tests in the small wind tunnel, large wind tunnel and field, involving a total variation in Reynolds number of about a factor of 4000 . We do not believe that the addition of smaller field tests, or of larger ones involving up to $1000 \mathrm{~m}^{3}$ of LNG, as suggested by the Livermore reviewers, will importantly increase the understanding and confidence in the scaling of vapor dispersion. This is because going from 350 to $1000 \mathrm{~m}^{3}$ spills increases. the Reynolds numbers by only a factor of 1.4 if the wind speed is held fixed or 1.7 if the speed is Froude-scaled, while smaller field tests only add points between the wind tunnel and large field tests. Moreover, if they are fairly sma11, it is difficult to find a natural steady wind low enough to permit significant gravity spreading.

Havens and Colonna also mention the recent paper by 
van Ulden (Ref. 11-2), which shows that the commonly used Froude number scaling is not always applicable. However, that paper merely criticizes a frequently assumed relation between the outward velocity of a heavy cloud front and its height, which is equivalent to assuming that the local Froude number at the front is a universal constant. Instead, van Ulden shows that it should vary as the cloud expands and also depend on the cloud-to-air density ratio, unless this ratio is close to unity. His results do not contradict our more general assumption of Froude scaling. They do, however, indicate that the suggestion by Meroney, to use a test gas denser than LNG vapor (i.e., $\rho_{\text {gas }} / \rho_{\text {air }}>1: 4$ ) to obtain the desired Froude number at a higher wind speed, will not give an accurate simulation.

Welker and the Battelle reviewers doubt the safety of using LNG in wind tunnels. We emphasize that to fulfill the test purposes the LFL boundary must lie within the test section, so that downstream the vapor concentration will be well below the flammable range. For the nonrecirculating tunnels recommended in section VI this minimizes the safety problem. We also discussed the question with operators of the tunnels, and although they made no commitments they did not immediately reject the idea. If use of LNG is not permitted, a nonflammable simulant (cold or warm) can be used, with some loss in the accuracy of simulation, as discussed on pages 6-18 and 6-19.

Drake and the Battelle reviewers question our rationale for selecting $350 \mathrm{~m}^{3}$ as the maximum test spill size. We still hold to our argument that tests of about this size are needed to simulate full-tank spills on water in a $2 \mathrm{~m} / \mathrm{s}$ wind, and that going to a somewhat larger size only improves the simulation slightly, while increasing the cost greatly. 
Havens and Williams believe that we are too optimistic in our estimates of the value of detailed numerical computations, due to the limitations of turbulence models. It may be true that not all of the recommended mathematical modeling tasks will be successful, but we believe that enough will prove so to make the effort worthwhile.

Fay responded by telephone that he'd just had time to read the report rapidly, and had only the general comment that he now believes the vapor dispersion problem is not as difficult as he once thought; therefore, a research program as big as we recommend is probably not warranted. He also sent a copy of a review paper, "Gravitational spread and Dilution of Heavy Vapor Clouds," which he gave at a recent meeting in Norway. This paper summarizes the considerable recent theoretical and experimental progress made on the subject, but concludes that "many important questions remain unanswered."

Lind suggested that we put more emphasis on the measurement and interpretation of atmospheric conditions. His latest field test employed many wind sensors, which showed that the wind speed and direction varied considerably with position and with time over the 3-min spill duration.

On water spill tests, Haselman recommended omitting the ship model, since in a real accident the ship may drift away from the cloud, and this represents the worst case because the ship's aerodynamic wake would promote turbulent mixing. This omission simplifies the test program, since the shiporientation parameter can be dropped. We believe that this is a promising simplification, but its rationale should be studied further before implementation.

Finally, a question raised by Walter has caused us to add to page 6-32 a more complete explanation of why we 
recommend a different deployment of concentration sensors in the large wind tunnel than in the small one.

9. COMMENTS ON SECTION VII (POOL FIRES)

Welker and the Battelle group suggested practical problems in our recommendation to test fire-fighting equipment during one of the pool fires. We agree that the possible problems of delayed firefighting and equipment interference must be considered seriously and may make our recommendation impractical. On the other hand, we disagree with Welker's suggestions to precool the soil to make the burning more steady and to employ many wide-angle radiometers to measure "what we eventually want to know." Precooling would prevent simulation of the earliest and probably strongest radiating period of an accidental fire, while the value of wide-angle radiometers is limited because they do not measure the spatial and spectral variations needed to apply data from test: fires to the much larger fires of primary interest.

Drake suggests that at distances of practical interest the China Lake radiation data do not give twice the flux that would be predicted from earlier formulas because the new data have peaks at wavelengths that are strongly absorbed by the atmosphere. However, we believe that for much larger flames their greater optical depth will make their spectra approach a black body, and hence they will give about double the previously predicted flux even at a distance. Drake also expresses two specific concerns for the safety of our proposed spill tank; these need to be considered, although the surplus tank we located does not have an outer shell to be damaged.

The Battelle group suggest that our recommended LNG volumes for the pool fires may be too small to produce an 
adequate flame before burnout or composition change due to differential boiloff. We disagree; the dike spill volumes are chosen to give a burning duration of about $5 \mathrm{~min}$, and the water spill volumes are much larger than those employed at China Lake. Battelle also recommends a task to investigate soot properties; we include this in our flame-modeling task (page 7-21).

Markstein said via telephone that this section and the following one (on vapor cloud fires) sounded good, and his only suggestion was to perform each fire test twice because fires have considerable variability even when one tries to control all the parameters. This was true of the old AGA tests and even of the large indoor fires with which he has worked. Accordingly, he would not put too much trust in a measurement unless it were repeated on a second similar fire. In response, we have increased the number of contingency tests from two to six, with the idea that some of these will be duplicate tests, the results of which will determine whether all the tests need to be duplicated.

10. COMMENTS ON SECTION VIII (VAPOR CLOUD FIRES)

Drake suggests that this area needs more emphasis because it is the area where the fewest controlled experiments have been conducted in the past. Both she and Haselman recommend a number of small field tests before going to the large ones. We agree on the need for emphasis, and have added four more contingency tests to Table 8-1. However, we feel that small vapor cloud fires are not very relevant to large accidental fires since buoyancy induced motions are much more important in the latter.

Benedick thinks that the fireball type of burning cannot be ruled out. A.lso, he recommends the use of inexpensive integrating calorimeters, consisting just of blackened 
copper sheets with dots of temperature-sensitive paints on the back, which have worked well in various Sandia experiments. We concur in their use as a backup of the more sophisticated radiation instrumentation.

Williams mentioned the recent experiments and theoretical analysis by Kaptain and Hermance (Ref. 11-3) of flames propagating horizontally through fuel-air clouds in an open trough. We agree that this work may be quite pertinent. Although the clouds in those experiments were only a few centimeters high and the flames were laminar, the ratio of burning velocity to buoyancy-induced velocity could be comparable to that in larger turbulent flames.

\section{COMMENTS ON SECTION IX (EXPLOSIONS)}

Drake and Welker feel that work on explosions should have low priority, with Drake excepting the case of tanks on a pile cap foundation. For reasons presented on pages 9-4 and 9-5, we believe that the possibility of large. LNG vapor cloud explosions is appreciable enough to require careful investigation. Also, Drake apparently overlooked the inclusion of the elevated tank configuration in our test program (bottom. of page 9-17).

Haselman pointed out that we erred in labeling the ordinate of Figure 9-2 "Burning Velocity." This error was due to ignoring the motion induced in the unburned cloud by the expanding combustion products, which can make a large difference. The figure has now been relabeled and the discussion on pages 9-5 to 9-7 revised to clarify this point. Haselman also feels that explosions are the most uncertain phenomena, that they can depend upon many parameters, and that the possibilities will not be greatly reduced by the survey of initiation sources. Consequently, he thinks it important to do a large number of explosion experiments, such 
as Lee's new experiments in a very large tube $13 \mathrm{~m}$ in diameter and $10 \mathrm{~m}$ long). We favor a considerable number of experiments of various types, as indicated in section IX, but we believe that the initiation source survey will considerably reduce the number of configurations of practical interest.

\section{COMMENTS ON SECTION X (COST AND TIME ESTIMATES)}

The only comments received on this section were from Lind and the Battelle and Livermore groups. All felt that our time and cost estimates were considerably too low. Battelle and Livermore suggested that this was due in part to our paying inadequate attention to safety considerations.

Our estimates in this section were derived from a fairly detailed consideration of the manpower and equipment needed for each task. The duration and cost assigned to the theoretical and smaller experimental tasks were based on our own experience and on discussions with people doing this type of work. For the large field tests, the prices of the major physical items, such as the LNG, spill tanks, excavation and grading, and instrumentation were established by contacting potential suppliers. The time schedule and facilities selected for the field tests were estimated partly by drawing on our experience with the large high-explosive field tests conducted periodically over the last decade by the Defense Nuclear Agency (see page 4-4), which we believe are quite relevant. In those operations, portable instrumentation trailers were used, and the primary safety measure was to keep all personnel at a safe distance from the test, rather than constructing hardened facilities. In addition, the tests were performed by individuals from government and industry who were experienced in conducting large hazardous tests and motivated to complete them in a timely fashion.

The validity of our estimates was also confirmed by discussions with persons at Sandia Laboratories and at the 
Defense Nuclear Agency Field Command who were experienced in conducting large hazardous field tests. In addition, independent unofficial estimates were made by L. J. Vortman (Sandia Laboratories) for the field test on-site personnel, instrumentation, data reduction and reporting. His total for these items was about 5 percent lower than our total, although his estimates for two of the three items differed from ours by a larger percentage.

For the above reasons; we believe that our cost estimates and time schedule are reasonably accurate, provided that the appropriate people are selected to carry out the work.

It should be mentioned that in this final report version the field test costs have been increased by $\$ 1.1$ million to allow for the eight fire tests added since the draft report was distributed, as explained above in subsections 9 and 10 . 
11-1. Bridgman, P. W., Dimensional Analysis, Yale University Press, 1931.

11-2. van Ulden, A. P., "The Unsteady Gravity Spread of a Dense Cloud in a Calm Environment," paper presented at the Tenth International Technical Meeting of the NATO Committee on the Challenges of Modern Society, Rome, Italy, October 1979.

11-3. Kaptein, M., and Hermance, C. E., "Horizontal Propagation of Laminar Flames Through Vertically Diffusing Mixtures Above a Ground Plane," Sixteenth Symp.

(Internat.) on Combustion, Combustion Institute, Pittsburgh, PA, 1976, pp. 1295-1306. 


\section{APPENDIX}

WRITTEN COMMENTS RECEIVED

FROM TECHNICAL REVIEWERS

$A-1$ 
THIS PAGE

\section{WAS INTENTIONALLY LEFT BLANK}




\section{Arthur D. Little, InC. aCorn PARK. CAMBRIIGE,MA 02140. (617) 864-5770. TELEX 921436}

May 12,1980

Dr. Forrest R. Gilmore

R\&D Associates

Post Office Box 9695

Marina del Rey,

California 90291

Subject: Commentary on Draft Report RDA-TR-111000-001

"Recommended Research on LNG Safety"

Apri1, 1980

Dear Forrest:

After a fairly quick review of the subject document to meet your request for a response within three weeks, I have a number of comments and concerns -many of which I have discussed with you and Jerry Carpenter in the past. This letter will first sumnarize the more significant points.

1) The first step in designing a national LNG safety research program would seem to be identification of the models needed for regulatory and emergency planning decision making. Then, the effect of present uncertainties and deficiencies in hazard models would be evaluated in light of regulatory needs. While Chapter II discusses regulations, the regulatory needs thus Identified seem to be largely ignored in the research plan.

For example, the new Part 193 regulations indicate that tank pressure relief systems should be designed considering the potential for tank "rollover" events. Although some theoretical models are available for predicting vapor generation rates in a "rollover", these models are subject to much uncertainty and are not experimentally verified. The basic research program at MIT under GRI sponsorship is unlikely. to provide a solution to this problem for several years and MIT is not equipped to run tests in reasonable scale with LNG. This regulatory need is not addressed in your proposed program.

Also, Part 193 bases most vapor dispersion exclusion zone requirements on design accidents involving pipe spills into impounding systems, rather than on catastrophic tank failure. Continuous rate spill tests into diked areas would thus seem to be a research area of priority regulatory interest. 


\section{ArthurD Little, Inc.}

Dr. Forrest R. Gilmore

May 12,1980

R\&D Associates

Page 2

The new regulations also require that tanks constructed on a pile cap foundation be designed to withstand forces associated with ignition of a flammable LNG vapor mixture under the tank. This represents a partiallyconfined environment and some overpressures appear to be anticipated by the regulatory language. Again, this is a regulatory research need which is not included in your proposed program.

Finally, does the U.S. Coast Guard feel a need to refine estimates of downwind vapor cloud travel beyond the present state of the art? Would uncertainties in present hazard assessments cause them to modify any of their regulations or emergency planning? The U.S.C.G. has been conducting LNG spill tests at China Lake to expand their knowledge of LNG fires on water and vapor cloud fires. It would seem logical for DOE to look to the U.S.C.G. for guidance and cooperation in planning future LNG water spill experiments to assure that the Coast Guard test experiences and regulatory needs are fully considered.

If the program were directed toward just the actual regulatory needs, the proposed $\$ 20 \mathrm{M}$ budget could be substantially reduced.

2) On p. 4-1 it is stated that LNG fire emissive powers measured at China Lake are about twice those estimated for earlier LNG land fires. This is somewhat misleading. The earlier estimates of emissive power treated the flame as a black body emitter and were estimated using the measurements of wide angle radiometers and the emitting area of the fire. The China Lake information is based on narrow angle radiometers. Further, spectral analysis shows that the LNG flame is not a black body emitter - there are large emissions in the water and $\mathrm{CO}_{2}$ bands and much of this energy is selectively absorbed by water vapor and $\mathrm{CO}_{2}$ in the atmosphere. At distances of a few diameters from the flame, the differences between old and new models is not as large as a factor of two.

3) On p. 4-2, arguments are made for a "rapid" program. Certainly it is less. expensive to run tests in quick succëssion. However, from much experience with a variety of experimental programs -- from the early AGA spill tests with which Jerry Carpenter was involved to the more recent tests at China Lake -- the rapid approach inevitably leads to obtaining a lot of imperfect data and a need to eventually repeat some tests. In the end, a slower approach is more beneficial to the quality of the results and probably is more economical. 


\section{ArthurD. Little, Inc.}

Dr. Forrest R. Gilmore

May 12,1980

R\&D Associates

Page 3

4) The rationale for selecting $350 \mathrm{~m}^{3}$ as the test spill size seems weak. These will be very large and expensive tests. While much will be learned in the wind tunnel work, it would appear reasonable to conduct tests at a somewhat smaller scale first. These tests would be less expensive and could be used to check the wind tunnel predictions before designing the very large tests. For example, AGA ran a few dike tests involving about $40 \mathrm{~m}^{3}$ spills and the China Lake tests will also provide dazta for $40 \mathrm{~m}^{3}$ spills on water. It would be interesting to conduct some $40 \mathrm{~m}^{3}$ spills at the new test site to learn the importance of site specific effects. Some tests might also be conducted at an intermediate size -- perhaps $100 \mathrm{~m}^{3}$-- with the largest tests being a check to see if scaling models are valid.

It seems unlikely to me that information will be obtained from the $350 \mathrm{~m}^{3}$ tests that will fully resolve questions about gravity spreading effects. And the goal of being able to quantify vapor dispersion distances within $\pm 10 \%$ seems totally unrealistic -- and probably unnecessary.

5) While the goal of developing good theoretical models is of great academic interest (to me and many other researchers), the complex nature of actual accident conditions make the usefulness of sophisticated models quite limited. In shipping accidents, the quantity and rate of spill are usually unknown. The geometry of the ships involved may be hard to ascertain in the presence of a vapor cloud or fire. Thus, the objective for emergency planning purposes is to be able to bracket the potential effects in general terms.

On p. 6-4 you note thąt the Germeles-Drake model predicts an $18 \mathrm{~km}$ distance to LFL for a $25,000 \mathrm{~m}^{3}$ spill under Class $\mathrm{F}$, whereas Sigmet would predict about a $3 \mathrm{~km}$ distance. Interestingly enough, and not noted by you, is the fact that Sigmet predicts much longer downwind distances for higher wind speeds than does the Germeles-Drake model.

Thus the potential hazard zones do not differ by as much as a factor of six. Rather they differ because the Germeles-Drake model predicts the greatest hazard distance at low wind speeds whereas Sigmet predicts it at high wind speeds. It could be of interest to emergency planners to know whether wind speed increases or decreases the downwind hazard zone for large spills. Thus some tests, both in the wind tunnel and in the field, should be directed toward resolving this basic issue.

\section{Minor Points}

6) Page 4-6. The argument against studying $40 \mathrm{~m}^{3}$ spills because there are only 70 trucks in the U.S. is 1llogical. The program focusses on catastrophic ship and storage tank spills which also involve an equally limited number 


\section{ArthurD. Little, Inc.}

Dr. Forrest R. Gilmore

May 12,1980

$R \& D$ Associates

Page 4

of potential objects. Also, these catastrophic accidents are much less likely, in my opinion, than piping spill and truck accidents which are not treated in the proposed program except for the ship unloading accident scenario.

7) The boiling/spreading experiments described in Chapter 5 seem largely unnecessary. From the China Lake tests, we know that spill geometry and force greatly influence the interfacial area and thus the boiling and spreading behavior. Again, in a real accident, it will be of limited use to have a highly refined boiling and spreading model. Further, downwind dispersion and pool fire estimates are fairly insensitive to errors in the boiling/spreading model.

8) Page 7-15. These experimental plans should get a careful safety review. External insulation on the spill tank could cause a carbon steel shell to operate below allowable temperature limits. Also, the outer false tank could give an enclosed area where some minor LNG leakage could produce a potentially flammable mixture.

9) Chapter 8 addresses the area where the fewest controlled experiments have been conducted in the past. Therefore, vapor cloud fire tests should receive more emphasis in this program. Also it would seem useful to study vapor cloud fires on a smaller scale before conducting $350 \mathrm{~m}^{3}$ tests.

10) Major research attempts to find conditions under which LNG vapors may detonate (by distributed ignition sources, with aerosol present, etc.) do not seem to be of priority to support regulatory needs. The exception is the specific area of ignition of flammable vapor under a pile cap tank foundation.

Deflagration studies could appropriately be combined with the vapor cloud fire studies to see how the presence of objects influences flame propagation rates.

While development of codes for predicting fast deflagration behavior is of academic interest, it does not appear necessary for this program. Also, such models could be developed and tested more readily with gases which are easier to detonate than methane or LNG.

I would be glad to discuss any of these points further if you wish.

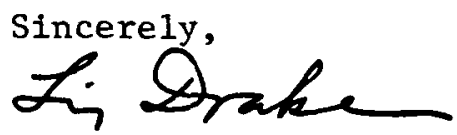

Elisabeth M. Drake

EMD : mec

cc: Dr. John Cece 


\section{Applied Technology Corp.}

401 WEST MAIN STREET SUITE 220

NORMAN, OK 73069

405-364-5431
P.O. BOXFF

NORMAN, OK 73070

TWX 910-830-6525

May 16,1980

Dr. Forrest R. Gilmore

R\&D Associates

P. O. Box 9695

Marina del Rey, CA 90291

Re: AT-112-L-27

Dear Dr. Gilmore:

I have read through the draft copy of your Report No. RDA-TR111000-001, "Recommended Research on LNG Safety." While I have not had enough time to make a thorough technical review, I have several general comments concerning the proposed work:

1. As I understand it, the purposes of the research are to improve LNG safety and to provide additional information that might be needed for regulatory activities related to LNG. I'm not certain that either goal will be reached, perhaps not even appreciably aided.

2. We already have an appreciable body of knowledge on LNG vapor clouds, fires, and fire control; in my opinion the knowledge is sufficient to allow LNG operations to proceed at a safety level greater than that found for most, if not all, other hydrocarbon fuels. We do not have analytical techniques for predicting behavior within \pm 10 percent. In my opinion, we (a) do not need that kind of accuracy and (b) cannot obtain it within the foreseeable future.

I don't mean to indicate by the above general comments that I'm not interested in either the test programs or the results. I think the results will be interesting and the tests would be fascinating for the participants. My concern is that we will think we have made progress but have really solved problems that are primarily of academic interest and do not improve LNG safety.

I have a few specific comments that came to mind as I read the report. They can be considered if tests are in fact run:

1. I don't think fire extinguishment and/or control tests are practical in conjunction with the dispersion and fire tests 
unless longer duration tests are planned. Even then, there will be some potentially serious problems with system design because the fire protection systems are usually designed for fairly rapid action, particularly the dry chemical systems. A long exposure to a fire increases the probability of system malfunction due to overheating of components during the fire. Manual systems using hoselines and monitor nozzles might be tried, but the system capacity would be so large that as many as half a dozen monitor nozzles or several dozen hoselines would be required for the $30 \times 25 \mathrm{~m}$ test, for example. For high expansion foam, about $50,000 \mathrm{cfm}$ of foam would be required and the foam distribution system might interfere with the fire tests.

2. We have found that simple bubbler systems can provide rapid and fairly accurate measurements of boiloff rate and burning rate. Since the measured rate is a mass loss rate, there is no problem in correcting for density changes caused by differential boiloff or in measuring loss rates when there is boiling or foaming.

3. I wonder if the field tests will have a long enough duration to give an adequate characterization of both mean and

fluctuating gas concentration, particularly for spills on water. The variable boiloff rates will be an additional complicating factor, again especially for water spills.

4. The wind tunnel tests probably cannot be run using LNG. As pointed out in the report it will probably be necessary to use cold gas. Even then, I seriously question the ${ }_{3} \mathrm{smal1}$ (4-m) spil1 quantities. The smallest quantity, $0.025 \mathrm{~cm}^{3}$ of LNG equivalent; is only a small drop. In terms of cold gas it is about $5 \mathrm{~cm}^{3}$, or about a teaspoon of vapor. Even at 1 percent in air, the total volume of mixture would be only about a pint, which is not very much for reliable testing, even if released quite rapidly.

5. Analysis of spill fire tests will be more difficult if nonsteady burning is used. I think it would be better to spill larger quantities and allow the soil to pre-cool before ignition for at least one of the tests.

6. I would use several times as many wide angle radiometers as planned, perhaps as many as 25 to 50. They are, after all, about the only instrument that tells what we eventually want to know, i.e., the incident radiant flux at a given location. 
Skin simulants and wood targets will be helpful, but their results will be more difficult to interpret and harder to obtain.

7. I think that some of the ignition conditions proposed in Table 8-1 are naive. I don't think that the understanding or control of test variables will enable us to ignite a cloud at its downwind edge at maximum extent. Neither do I think such a test would provide much useful information. Ignition at the centroid may provide more useful information, but a priori location of the centroid may be difficult and the concentration may be above the upper flammable limit.

8. I suppose that some time a system will be designed to initiate a detonation in an unconfined methane-air cloud. However, with all the effort expended to date on stoichiometric mixtures and the lack of success, I wonder if it's worth the effort to keep trying.

I apraneciate the opportunity to review your report. If you have any questions o.l my comments, please let me know.

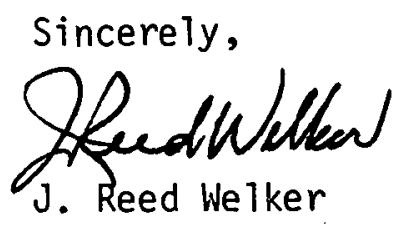

JRW:akh

cc: Dr. John Cece 
May 20,1980

COMMENT BY J. A. HAVENS ON

R \& D ASSOCIATES DRAFT REPORT, RDA-TR-111000-001, "RECOMMENDED RESEARCH ON LNG SAFETY,". April 1980

I am restricting my comments to the recommended research on LNG spreading, evaporation, and vapor dispersion since I am more familiar with these problems and because I am confident there are other reviewers better informed than I on the questions remaining in the assessment of potential hazard of liquid pool fires, vapor cloud fires, and unconfined vapor cloud explosions. However, I believe the latter questions will remain unresolved until the questions regarding liquid spreading, evaporation, and vapor dispersion are satisfactorily addressed, since these processes are important initial conditions to the problems of predicting the combustion hazard.

I have two types of problems with the proposed research program on LNG spreading, evaporation, and vapor dispersion. First, the suggested program gives no explanation of how the suggested tasks are to be affected by the results from the current research program being conducted by DOE. Although I am not familiar with the detailed experimental plan for the current DOE work, it is my understanding that DOE will 
conduct approximately twenty field releases of LNG of $20-40$ $\mathrm{m}^{3}$ size to study the same problems outlined in the RDA report. Furthermore, it is my understanding that a number of pre-field-test and post-field-test experiments are planned in the Colorado State University wind Tunnel, which I assume also address the questions outlined in the RDA report. It seems to me that a research plan of this magnitude cannot possibly be judged without due consideration being given to the current test program at China Lake, California.

Second, and disregarding the lack of coordination of this proposed plan with efforts ongoing at China Lake, I offer the following observations regarding the detailed research program on LNG spreading, evaporation, and vapor dispersion:

1. At the outset, I do not believe that the goal set forth on page 6-5 to." develop techniques that permit the determination of the distance to a given mean LNG vapor concentration for a specified LNG site, spill and weather, with an uncertainty to \pm 10 percent. . ." can be met by the proposed program even if no unforeseen problems arise in its conduct. The current understanding of turbulent dispersion in the atmospheric boundary layer is, in my opinion, insufficient to such a goal. Uncertainties of \pm 108 can not be claimed at present even for predictions of neutrally A-11 
buoyant material dispersion, wherein the problems peculiar to LNG vapor dispersion (such as gravity spreading) do not exist.

Furthermore, it must be realized that existing dispersion data (such as Gaussian dispersion coefficients) are large. ensemble averages in which the individual experimental data depart from the average by considerably more than 10\%. There is no provision (nor am I suggesting there should be) for sufficient testing to determine such ensemble averages; in view of which, claims for $\pm 10 \%$ uncertainty in prediction of such events are, in my opinion, not. credible.

2. The program structure relies heavily on the use of similarity theory and associated wind tunnel testing of the spreading evaporation and vapor dispersion processes. The rationale of performing wind tunnel tests which are scaled versions of the proposed field tests, with concurrent'mathematical model testing using wind-tunnel-derived vapor dispersion data, is good, but I am not convinced that the scaling laws are known'with the degree of certainty which is implied in the proposal. Disregarding problems which may be identified due to the inability to preserve Reynold's 
number similarity, the scaling of the liquid spread and gravity vapor spreading process is assumed to depend on the Froude number. It should be recognized that froude number scaling of gravity currents, which is the basis for most of the currently proposed theoretical treatments of gravity spreading of heavy vapors, has been reasonably verified only for steady gravity currents (i.e., where the velocity of advance of the heavy gas front has reached a steady value). Even in the case of steady gravity currents, there is some uncertainty about the phenomenology of mixing between the heavy and less dense gas layers. The recent experiments by Britter and Simpson (1) referred to in the proposal (pages 6-10) and by other papers by Britter and others $(2,3,4)$ indicate little, if any, mixing between the advancing heavy gas layer and the environment except at the leading edge: The mixing at the leading edge is suggested to occur due to Kelvin-Helmoltz $\rightarrow$ instability. This is an important finding, which, if true for large scale releases of LNG, may require changes from the methodology incorporated in most presently used models such as the Germeles-Drake and SIGMET models. I do not believe the interfacial mixing is sufficiently 
understood yet to allow straightforward application of the proper scaling laws. I do not see; for example, how the mixing at the gravity current head, described by Britter, can be incorporated into the scaling methods proposed by RDA. In my opinion, this is an area where more laboratory or small scale wind tunnel work is indicated before large scale releases are attempted.

With respect to the steady nature of gravity currents which are scaled by preserving Froude number similarity, it does not, in my opinion, follow that similarity will be obtained using Froude number scaling for highly transient gravity spreading phenomena such as would be expected in large scale, sudden, LNG releases. van Ulden has recently discussed this problem and concluded that the commonly used Froude number scaling is not always applicable (5).

3. In the mathematical modeling portion of the proposed program I believe the goal of development of a three-dimensional, time-dependent, hydrocode which accounts for mass and energy transfer using second order turbulence "closure" methods is over-ambitious for this program. Such models can of course be developed and indeed, might be available at present. However, $\mathrm{A}-14$ 
I am not convinced that such uncertainties as now exist due to the inadequacy of modeling turbulence using eddy viscosity, thermal conductivity, and diffusivity (first-order closure) approaches would be relieved by incorporating higher order closure schemes. In my opinion, the primary uncertainty in modeling mixing between the heavy gas layer and the environment is between descriptions such as the one currently used in SIGMET, which is based on a gradient concept, and a very different type of mixing such as that suggested earlier by Britter. It is hard for me to see how that question will be addressed by the inclusion of higher order turbulence closure schemes.

Finally, I still believe that highconfidence calculation of dispersion of vapor mixtures and the modeling of the turbulent fluctuations with such advanced methods is unrealistic to expect in the time frame and with the efforts outlined.

\section{References}

1. Britter, R. E. and J. E. Simpson, "Experiments on the Dynamics of a Gravity Current Head," Journal of Fluid Mechanics, 88, 2, 1978, pp. 223-240.

2. Simpson, J. E. and R. E. Britter, "The Dynamics of the Head of a Gravity Current Advancing over a Horizontal Surface," Journal of Fluid Mechanics, 94, 3, 1979, pp. $477-495$.

$$
A-15
$$


3. Benjamin, T. B., "Gravity Currents and Related Phenomena," Journal of Fluid Mechanics, 31, 2, 1968; pp. 209-248.

4. Britter, R. E., "The Spread of a Negatively Buoyant Plume in a Calm Environment," Atmospheric Environment, 13, 1979, pp. 1241-1247.

5. van Ulden, A. P., "The Unsteady Gravity Spread of a Dense Cloud in a Calm Environment," paper presented at loth Intl. Technical Meeting of the NATO CCMS, Rome, Italy, Oct. 26, 1979. 
Department of Civil Engineering

Fluid Mechanics and

Wind Engineering Program

(303) 491-8572
Colorado State University Fort Collins, Colorado 80523

30 May 1980

Dr. Forrest R. Gilmore

$R$ \& $D$ Associates

P.0. Box 9695

Marina del Rey,

California 90291

\section{Dear Forrest:}

I have examined with interest your report Recommended Research un LNG Sufety, RDA-TR-111000-00்i. Since 1 am a bit harassed for time as I prepare for a sabbatical year in Germany at the University of Karlsruhe (June 1980-May 1981), I have only read generally and not checked for numerical accuracy.

I feel the case you have presented for LNG simulation is quite good and represents the current state of the art. We have now completed a comparison between the China Lake LLL field measurements and our wind tunnel measurements (Neff and Meroney (1979)). You may desire to note this"material in Section VI.

I feel there is a place for further heavy isothermal gas releases in your test program. These tests would be especially valuable during numerical model verification since they eliminate the additional variables of temperature and humidity. Future interests may also include prediction of ammonia, chlorine, or propane dispersion. Such tests will make the entire set of experiments more useful.

If you permit the use of isothermal gases as well as specify the Froude flux number $F_{r_{F}}=\frac{U^{3} \ell}{g \frac{\Delta \rho}{\rho} Q}$ and vapor release

rate $Q / u l^{2}$, then it is possible to distort density ratio and operate at wind tunnel velocities which simulate less than $5 \mathrm{~m} / \mathrm{sec}$ in the atmosphere (i.e., $2.5 \mathrm{~m} / \mathrm{sec}$ ). 


\section{is :}

If you have any questions, my address this coming year
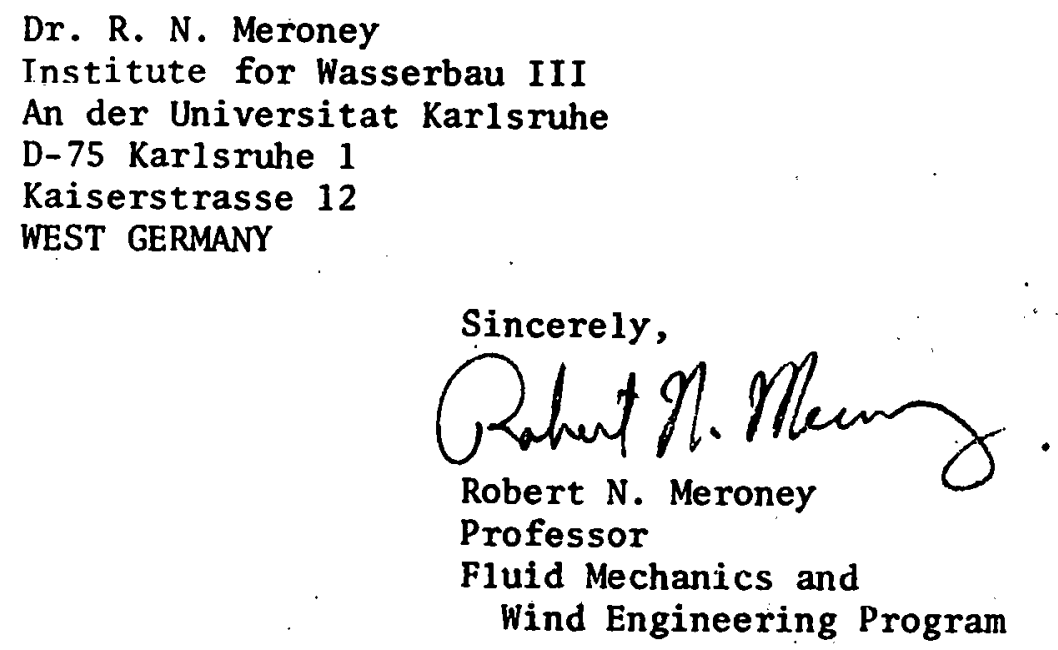

RNM: $1 w$

Enclosure: CER78-79-41 


\section{DEPARTMENT OF TRANSPORTATION UNITED STATES COAST GUARD}

MAILING ADDRESS: W.S. COAST GUARE-PMT-1/TP54) PHONE:

(202)

426-1058

T.9 JUN $190 \%$

3900

Ser : 0045R

- Dr. Forrest R. Gilmore

R\&D Associates

P.O. Box 9695

Marina Del Rey, Califorinia 90291

Dear Dr. Gilmore:

Thank you for the opportunity to review the draft report "Recommended Research on LNG Safety" (RDA-TR-111000-001) dated April 1980.

I have two comments only, regarding the report. There has been no attempt, apparently, to coordinate the results and developments from the current research program being conducted by DOE with the suggested program. The DOE test plan currently calls for field test releases of up to $40 \mathrm{~m}^{3}$ of LNG in tests similar to those proposed in the RDA report. In conjunction with the pre-test planning. for the DOE program, Colorado state University (CSU) is performing wind tunnel simulations for siting of the DOE instru ment array during the vapor dispersion tests at NWC, China Lake, Ca. CSU will also perform post-field-test experiments. The scope of the CSU effort would again seem to parallel some of what is in the RDA report.

Secondly, it seems too much emphasis has been placed on the wind tunnel testing and corresponding similarity for the spreading, evaporation, and vapor dispersion processes. The appraoch in the RDA report has been to match the proposed field tests to the proposed wind tunnel tests. It has been my experience, that one always conducts the fuil scale field tests which it is possible to perform and supplements the results with scaled wind tunnel simulation for testing which exceeds the limits feasible for fieid testing. Thewind tunnel is matched to the field test, not the other way around. The uncertainties of Reynolds number and Froude number scaling would seem to dictate an approach reversed from that presented in the RDA report. A recent. paper by Van Ulden concluded that Froude number scaling is not always applicable (presented at Technical Meeting of the NATO CCMS in Rome, 1979).

The approach described in the RDA report is one, I feel, which we could not support. The current DOE effort represents a more feasible approach, one which clearly must be coordinated into the RDA proposed program. Results and developments of the DOE program currently in 


$$
\begin{aligned}
& \text { G-DMT-I/TP54 } \\
& 3900 \\
& \text { Ser: } 0045 R
\end{aligned}
$$

progress must be incorporated, and the limitations and uncertainties in " wind tunnel testing must be examined further.

Thank you again, for the opportunity to comment.

sincerely,

G. ${ }_{\text {G. Col Conn }}$

$A-20$ 
May 27, 1980

Dr. Forrest R. Gilmore

R\&D Associates

P.0. Box 9695

Marina del Rey, CA 90921

Dear Dr. GiTmore:

Thank you for your letter of April 21 inviting comments on your report "Recommended Research on LNG Safety", RDA-TR-111000-001. Key members of : our LNG Safety Studies Project team have reviewed your report. 'This letter contains a compilation of our comments.

Our overall impression is that your report provides a good appraisal of research needs in LNG safety and many recommendations worthy of consideration in planning the evolution of the DOE/ECT LNG Safety and Environmental Control Assessment Program. We perceive your report to be actually two distinct reports. Section II and Section III are very good reviews of the regulatery environment and are particularly vaiuable additions to the literature. Our principal points of criticism focus on your research plan. In general, your recommendations do not adequately build on, integrate, or complement ongoing work in the existing DOE/ECT Program. We question the realism of some schedules and costs and the apparent lack of cohesiveness of the recommended program. However, your effort adds much additional insight and perspective to the planning information available to the sponsor. On the bottom line, therefore, the RDA report is considered to be a useful product that can have a positive influence on the future course of the LNG Program. Detailed comments are given by report section and follow below.

SUMMARY

Statenients in the first full paragraph of $p$. XIV (1ines 5 through 9) apparentiy ignore the need to understand release mechanisms and characteristics as part of good LNG hazards analysis. The comment on line 20 
Dr. Forrest R. Gilmo, e

May 27,1980

Page Two

that current theoretical treatments are primitive and controversial is a rather sweeping statement and not completely supportable. Current models may be good enough depending on their intended purpose. On line 26, what is the justification that a prediction capability between \pm 10 and \pm 30 percent is a feasible or required goal of the proposed research program?

We do not agree that availability of surplus cryogenic tanks (Page $X V)$ is a major decision basis for the maximum test spill size. Line 10 may be clearer if written, "except for spreading and boiloff on water. . . ." Page XVI summarizes the cost and scheduTe estimates of the RDA proposed program. The Summary Section offers the first of several opportunities in the text to discuss how the proposed effort will complement, contrast or substitute for effort that is under way in existing programs. This would enhance the value of the RDA study.

\section{INTRODUCTION}

The logic in the first full paragraph of page 1-2 (1ines 12 through 21) is hard to follow. These statements suggest that spill prevention aspects are simultaneously well-founded and unpredictable. If spill prevention measures are adequate, why would we worry extensively about other spill consequences. We suggest there are uncertainties in the area of release characterization that are worthy of study.

II. CURRENT PROCEDURES FOR OBTAINING LNG PERMIT APPROVAL

Section II is an excellent review and would be a worthwhile publication separate from this report. A small point is our suggestion that it might be more convenient as an Appendix rather than as Section II. Another small point, page 2-4 (1 ine 2), is that statements be kept in plain English that engineers can understand. A discrepancy or typographical error appears possible in comparing pages 2-13 (1 ine 27) with page 3-2 (7ine 10). Is there a NFPA59A 1979 edition?

\section{LNG SAFETY INFORMATION FOR REGULATORY PURPOSES}

This section appears to be logically placed in the report; however, Section III.3 (Page 3-12) leaves the reader interested in more details than are presented. For instance, who were the twenty groups and individuals 
Dr. Forrest R. Gilmc

May 27, 1980

Page Three

contacted? Were recognized experts consulted? Were the earlier DOE/LNG Workshops considered? What conclusions, if any, can be drawn from this Section? Some consideration of these questions would enhance the value of this Section.

IV. GENERAL FEATURES OF THE RECOMMENDED LNG SAFETY AND RESEARCH PROGRAM

The general goal of the research program recommended in this document is mentioned first in lines 27 through 31 on page 4-3. We fully agree that engineering answers are the most important practical product of the program and are surprised this point isn't made earlier as the essential philosophy of the recommended program. As will be noted in subsequent comments, it appears that this philosophy has been forgotten from time to time in the detailed planning of the recommended program. The comments on page 4-4 (lines 5 through 11 ) provide a questionable analogy to the LNG case. On page 4-6, the neglect of LNG truck spills is not justified. These spills are probably as likely, or more likely, than the massive spills mentioned previously. 'They also involve more likely direct contact with the public.

V. RECOMMENDED RESEARCH ON LNG SPREADING AND BOILOFF

On page 5-1 (1ine 3) the word "explained" is somewhat an overstatement. Section I discusses this issue briefly and "mentioned" might be a better word. We would like to see an explanation of why the spreading of LNG through a dyke rupture is not a high-priority problem (page 5-2, line 16). On page 5-9, the statement on 1 ines 21 and 22 is not strictly correct. Hoult developed a boiloff model for LNG which accounts for spatial separation of the different components using a characteristics method. The statement in parenthesis starting on line 29 needs to be supported.

The treatment of boiloff rate for scaling purposes in wind tunnels is considered good. However, the statement on page 5-12 (starting line 8) regarding the spreading and boiloff of LNG on a solid surface should be supported in more detail.

The philosophy of a basic effort followed by a more detailed extended effort is good. We agree with the last statement' on page 5-32 (1ines 24 through 26). 
Dr. Forrest R. Giln. ב

May 27, 1980

Page Four

\section{RECOMMENDED RESEARCH ON LNG VAPOR CLOUD DISPERSION}

Our first point in this section concerns the statement on page 6-5 (1ine 5) that a reasonable reșearch goal is the determination of LNG vapor concentration with an uncertainty. of $\pm 10 \%$. Is this reasonable on the basis of group discussions mentioned on page 3-12, and does this correspond to the factors listed in Table 3-1? A more basic question, is a factor of 1.2 even feasible? We would like to see the statement on lines 23 through 25 supported by reason rather than belief.

The study assumes a priori that the LNG questions are scalable and that the scaling relations are correct. While the Reynolds number scaling presented is very plausible, the Froude number scaling is not. There appears to be a need for scaling law verification as part of the planned program. On page 6-18, the Froude number on 1 ines 14 and 20 are defined as the reciprocal of that in the second line definition on page 6-15. This is a minor point because the equality of the Froude number or its reciprocal is all that is required. However, it would be tidier to be consistent one way or the other throughout the report. On page 6-23 (1ine 22) the presumption that wind tunnels can be run with LNG vapor without building flammable concentrations is probably overly optimistic. Several design changes probably would be required to operate such a system safety. It is not apparent that these considerations are figured into the cost and schedule reportêd in later sections.

The task summaries presented in Tables 6-7, 6-8, 6-11, etc. are in an excellent basic format that should be extended throughout the report. In Tables 6-7 and 6-8; the anticipated duration of the tasks are judged to be inadequate for the scope of work defined. This comment applies generally to many of the other activities proposed in later sections.

\section{RECOMMENDED RESEARCH ON LNG POOL FIRES}

The recommended LNG pool fire tests detailed in Table 7-1 include LNG spill sizes that may be too small. The pool may burn out before an adequate flame develops and/or differential-boiloff changes the nature of the flame. We recommend a task be included to investigate the kinetics and radiative properties of soot. 
Dr. Forrest R. Gilmc.

May 27, 1980

Page Five

The philosophy of using field tests to develop firefighting knowledge is worthwhile in principle. We question whether the recommendations on page $7-14$, lines 1 to 3 are practical and suggest they possibly duplicate the training opportinities available in such courses as LGF Fire Prevention and Control conducted by the Texas A\&M University System.

VIII. VAPOR-CLOUD FIRES AND IX. RECOMMENDED RESEARCH ON THE POTENTIAL OF LNG VAPOR EXPLOSIONS

Apart from our comments on costs and schedules, there is general agreement with the recommendations of these two sections.

X. PRELIMINARY COST ESTIMATE AND TIME SCHEDULE

The general criticism of this section centers on the questionable confidence of the cost and schedule estimates. There are generally insufficient data presented to support the cost estimates. Based on our familiarity with preparing proposals for research and development work and intuitive feelings for the order-of-magnitude of work involved, many of the estimates presented appear to be low, in some cases by a factor of two or three. The fixed 15\% contingency inflator may not adequately cover the uncertainties of each task. These uncertainties do not appear to have been established according to the individual complexities and risks of each task. The use of existing facilities, shared instrumentation, surplus equipment, etc. looks superficially attractive, but many possible complications and uncertainties are not apparently considered, and the cost of these can be very large. There is an inadequate explanation or consideration of the safety problems involved in the use of these facilities and the corresponding requirements for safety and protection systems that may be needed.

Similar comments apply to the time schedule. The justification for the schedule is non-existent. An impression gained is that the overall duration was arbitrarily chosen. Many tasks are self-evidently or over-optimistically too short. Provisions for start up, necessary communications, authority to proceed, contingencies, and other practical considerations in project. planning and management appear to be totally ignored in the time schedule. 
Dr. Forrest R. Gilmo

May 27, 1980

Page Six

The schedule provided in Figure 10-2 does not indicate the timing and critical paths for information transfer and interaction between the tasks. This appears to be a critical defect emphasizing another impression that essential planned cohesiveness of effort which would be necessary to make this project a success is lacking.

The impression gained that the schedule has been given quite cursory attention and the grossly optimistic schedule of individual tasks detracts from the quality of the balance of this document. The tightness of scheduled events in some cases can be expected to have cost implications that apparentiy are not figured either as costed or contingency elements. It is felt that considerably more effort would be needed in the cost and schedule estimate to provide the sponsor with a basis for deciding between the options presented in this report and currently planned activities in the DOE Program. TYPOGRAPHICAL ERRORS

The following itemized typographical errors were found in the collective reading of the PNL Project Team. None of us proofread your document; however, we note the following to cover the possibility that they might otherwise be missed.

Page XV, line 5. to the other costs...

Page 2-58, line 17 . . inspection on 16 February 1978, in which ...

Page 3-4, 1ine 29 ... systems, high-expansion ...

Page 3-14, Table 3-1 Safety Parameter Column, Vapor Cloud Dispersion

Page $5-1$, bottom line . . of water (which does .....)

Page $5-18$, line $16 \ldots$ Raj and Kalelkar theory ...

Page 6-18, see above note on Froude number and its reciprocal . .

Page 6-42, 3rd from bottom .. representing the Battelle Columbus Laboratories . . 
Dr. Forrest R. GiImo, e

May 27, 1980

Page Seven

\section{GENERAL IMPRESSIONS}

Expected benefits of individual task results do not appear to be sufficiently described to provide a basis for evaluating the cost-benefit value of their results. There are also no contingency plans to back up potentially unsuccessful efforts. The program plan does not appear to consider and integrate the future results of other ongoing work in liquefied gaseous fuels research. Many facets of a given problem are considered in a commendable fashion; however, the program has not been organized in task elements and-work packages that provide a systematic and cohesive picture of R\&D needs. It is not clear which of the recommended methods of investigation and which task. will contribute to the stated objectives or what the real cost efficiency and reliability of the individual methods are. The authors may be overly concerned with internal fine-scale dynamics and thermal dynamics in an LNG spill. We feel that the bulk-oriented analysis is not being pushed far enough.

As stated previously, cost estimates appear to be too low and tasks are unrealistically short. Tasks overlap in areas where careful analysis requires completion of one task prior to the beginning of subsequent tasks. The program appears to require that distinct groups work simultaneously on related tasks which does not allow for appropriate communications between activities. We recommend all task effort be defined in work packages similar to the form presented in Table 6-7 and other tables in Section 6. The excellent work package summaries in these tables could be taken a step further. In addition to the items identified, alternative strategies should be indicated in the event that expected output is different than that indicated in the plan. The work packages should be justified in relation to the direction and expected results of other activities in the existing DOE Program and other LGF research activities. In general, a more substantial case for the proposed program would result if it were presented as a comprehensive approach that complements other current research. 
Dr. Forrest R. Gilmore

May 27, 1980

Page Eight

As it presently stands and to the extent some of the above points will be addressed in the final version, this report contains much useful information and justifications for specific tasks that are important and needed activities in LNG safety research. The authors are to be complimented on the value and insight provided in many of the recommendations in this report.

I hope the preceding comments may be of constructive help in your preparation of the final report.

Sincerely yours,

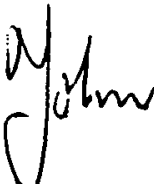<smiles>CC1CCCCC1</smiles><smiles>CC(C)(C)C(=O)c1ccccc1</smiles>

John G. DeSteese, Project Manager LNG Safety Studies

Energy Systems Department

$J G D: j f$

CC: Dr. H. F. Walter, DOE

Dr. J. M. Cece, DOE 
July 3,1980

Forrest R. Gilmore

$R$ \& D Associates

Post Office Box 9695

Marina del Rey, CA: 90291

Dear Forrest:

'Several LLNL staff members have reviewed RDA's draft document entitled "Recommended Research on LNG Safety". I will attempt to summarize our conclusions.

We found many of your recommendations to be quite good. For the most part, we have been proceeding along the recommended 1 ines for about two years. Due to funding limitations, our progress has been slower than the "forecast" in the RDA schedule, but many of the computer code evaluations, some developments, and some experiments have already been done. However, we also found many disagreements with details that were recommended in the report. For example, we have just finished designing, building, and fielding an instrument array and data collection system for large LNG vapor dispersion experiments. Our array differs in several significant respects from that recommended in your draft. Obviously, we feel our design is better for collection of the required data. However, since your report was not intended as a step-by-step guide, we choose not to elaborate here about these types of agreements and/or disagreements.

In a more general. view, we strongly agree with your conclusion that the experimental program should move more rapidly toward field tests in which a few hundred cubic metres of LNG are spilled. Our agruments are somewhat different from yours, but our conclusions are the same. We have believed for some time that clouds from larger spills under calmer conditions will be needed in order to observe the phenomena which may dominate the vapor mixing process (and, thus, determine the LFL) in large-scale accident situations of interest. Experimental cloud dimensions must be larger than characteristic dimensions of relevant atmospheric turbulence. In our view, acquiring a facility where up to a few hundred cubic metres of LNG may be spilled under low, steady wind conditions and allowing dispersion over a relatively smooth surface is a very high priority.

We disagree, however, with RDA's position that the field experiments should primarily be simulations of worst-case, large-scale accidents (i.e., the field tests are simply outdoor wind tunnel simulations). If this is all that is done, the program will be subject to criticism on several scores. First, someone will inevitably suggest another scenario different enough from the one simulated that a simple extrapolation will not suffice. Second, 
the applicability of Froude number scaling to our problem will be questioned (actually, it already has been). We believe that the number and type of experiments, the measurements, and the data analysis described in the RDA approach are insufficient to confirm the validity of Froude number scaling or to confirm the choice of scenarios. They certainly are insufficient to validate a physical or numerical model. Field experiments at different scale sizes will be required, some of which might have to be larger than those proposed by RDA.

The object of the DOE's program should be the development and verification of predictive tools that can be used by a number of persons and organizations. The tools should be capable of predicting accident phenomena under a variety of circumstances not tested in the large experiments. They may be used for establishing safe facility design requirements, regulating operations, or evaluating accident mitigation suggestions to name just a few. Validation of the models will require a variety of controlled experiments in the wind tunnel and in the laboratory and detailed measurements in the field. A few physical simulations (like those proposed by RDA) in the wind tunnel and in the field will also be necessary to confirm the prediction capability of the tools; however, they would not be sufficient alone. As mentioned by John Deutch two years ago, "This (approach) is part of the long, hard road to develop an understanding of the mechanisms that dominate the behavior of these fuels". We have been proceeding along this route for several years and believe the DOE should continue it.

As a final word, we believe RDA's cost and time estimates are overly optimistic, even for the abbreviated experimental program you outline. The, issue is not, as you claim, the permanence of the facility; it is the safety. In our view, inadequate attention was paid to safety in your recommendations. Since there has now been at least three LNG programs in which serious accidents have occurred, we believe the DOE should insist on adequate safety for its program. In general, the "quicky" experiments lead to safety problems. We estimate that adequate attention to safety in the design and operation of your proposed facilities and experiments would result in a significantly longer and more costly schedule; one which, in fact, would not differ significantly from what you call the "expanded" program.

Sincerely,

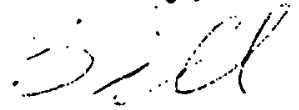

William J. Hogan LGF Program Leader

$\mathrm{WJH} / \mathrm{gp}$

CC - J. M. Cece, DOE, E-201

R. Kropschott, DOE

W. E. Mott, DOE E-201

file 